$$
\begin{aligned}
& \text { LEGAL POSITION } \\
& \text { OF TRADE UNIONS } \\
& \text { HENRY H. SCHLOESSER } \\
& \text { W. SMITH CLARK }
\end{aligned}
$$




LEGAL POSITION OF TRADE UNIONS 



\section{THE LEGAL POSITION OF TRADE UNIONS}

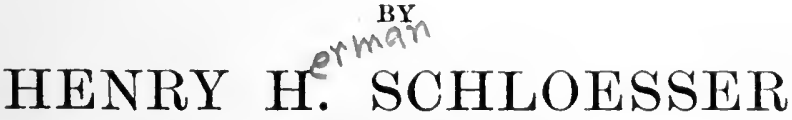

(OF THE INNER THMPLE, BARRISTER-AT-LAW ; LECTURER AT THE LONDON SCHOOL OF ECONOMICS, AND EXTENSION

, LECTURER FOR THE LONDON UNIVERSITY)

L.e. Sir Henry Slesser

AND

W. SMITH CLARK, M.A., LL.B. (EDIN.)

(OF THE INNER TKMPLL, BARRIS'JER-AT-LAW)

LONDON

P. S. KING \& SON

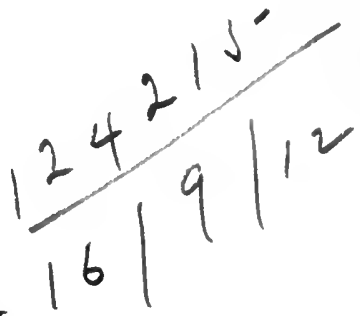

ORCHARD HOUSE

W E S 'T M I N S T E R 
Digitized by the Internet Archive in 2007 with funding from Microsoft Corporation 


\section{TABLE OF CONTENTS.}

PAGK

INDEX TO CASES CITED . . . . . . . Vii

ABBREVIATIONS IN EXTENSO . . . . . xxi

INDEX TO STATUTES CITED . . . . . XXiii CHAPTER

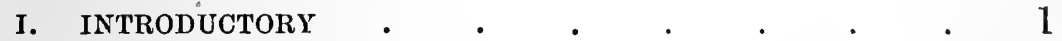

II. DEFINITION OF TRADE UNIONS AND THEIR POWERS . 21

III. DIRECT INTERFERENCE WITH THE DISPOSAL OF LABOUR

AND CAPITAL . . . . . . 56

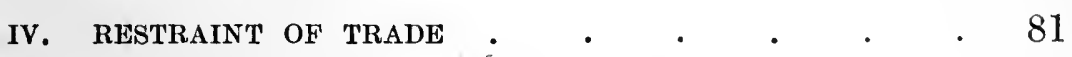

v. LIMITATION OF THE COURT'S JURISDICTION * . 123

VI. PROCEDURE . . ; . . . . . . 168 APPENDIX

I. STATUTES . . . . . . . . . 191

II. REgULATIONS OF THE SECRETARY OF STA'tE AND THE SECRETARY FOR SCOTLAND. . . . . 224

1II. FORMS AND PRECEDENTS . . . . . . 231

IV. SPECIMEN RULES OF A REGISTERHD I'RAUE UNION • 245

V. POWERS OF TRADE UNIONS UNDER THE NATIONAL

INSURANCE ACT, 1911 • • • . . 256

VI. INJUNCTIONS RESTRAINING LEVY OF FUNDS OF TRADE

UNIONS FOR PARLIAMENTARY OR MUNICIPAL REPRE-

SENTATION . . . . . . . . 258

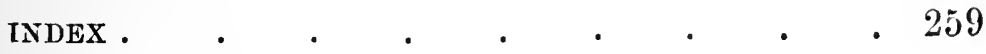





\section{INDEX TO CASES CITED.}

Aberdeen Master Masons' Incorporation, Ltd. $v$. Smith, (1908) 10 F. 669 ; 45 S. L. R. 484 ; 15 S. L. T. 953

Addison, Agnew $v$.

Agnew $v$. Addison, (1893) 20 R. (J. C.) 19; 3 White, 368 . $\quad . \quad . \quad . \quad . \quad .48(c), 177(b)$ Agnew $v$. Munro, (1891) 18 R. (J. C.) 22 ; 28 S. L. R. $335 ; 2$ White, $611 \quad$. $\quad . \quad$. $\quad$. $\quad$. $\quad$. 66 Aitken $v$. Associated Carpenters and Joiners of Scotland, (1885) 12 R. $1206 \quad$ • 14, 19, 128, 134-137, 168, $172,173,174$

Alfin $v$. Hewlett, (1901) 18 T. L. R. $664 \quad$ • . $\quad$. 178 Alison $v$. Balmain, (1883) 10 R. (J. C.) 12 ; 5 Cowp. 137180 Allen $v$. Flood, [1898] A. C. 1 ; 67 L. J. Q. B. $119 ; 77$ L. T. $717 ; 14$ T. L. R. $125 ; 46$ W. R. $258 ; 47$ S. J. $149 ; 62$ J. P. 595 . • • . . . . Amalgamated Society of Carpenters and Joiners, Russell $v$.

Amalgamated Society of Carpenters and Joiners, Sayer $v$. Amalgamated Society of Dyers, Burke $v$.

Amalgamated Society of Engineers and Others, Wilson $v$. Amalgamated Society of Railway Servants and Bell, Bussy $v$.

Amalgamated Society of Railway Servants $v$. Osborne (No. 1), [1910] A. C. 87; 79 L. J. Ch. 87; 101 L. T. 787 ; 26 T. L. R. 177 ; 54 S. J. 215 . 15-17, $19,20,22,25-29,31,35,39,112,169$

Amalgamated Society of Railway Servants, Osborne $v$. (No. 2).

Amalgamated Society of Railway Servants for Scotland $v$. The Motherwell Branch of the Society. See M'Laren $v$. Miller . 125, 128, 133, 135, 138-143, 147, 152, 155, $163,176,179$

Amalgamated Society of Railway Servants, Taff Vale Railway Co. $v$ : 


\section{viii INDEX TO CASES CITED.}

PAGE

Amos, In re. See Carrier v. Price . $\quad$. $\quad$. $\quad$. $\quad 50,51$ Andrews, Leng \& Co. $v$.

Anley, Walsby $v$.

Apperley, Peto $v$.

Ashbury Railway Carriage Co. $v$. Riche, (1875) L. R. 7

H. L. 653 ; 44 L. J. Ex. 185 ; 33 L.'T. 451 ; W. N. 123

Associated Carpenters and Joiners of Scotland, Aitken $v$.

Baker and Others $v$. Ingall, [1911] (Div. Ct.) 2 K. B. 132 ; 80 L. J. K. B. 699 ; 104 L.T. 456 ; 27 T. L. R.

321 ; 55 S. J. 409 (C. A., Times, 2nd December) . 123,

124,125

Baker, Underwood and Sons $v$.

Balmain, Alison $v$.

Barnum, De Francisco $v$.

Barrett $v$. Markham, (1872) 41 L. J. M. C. 118 ; 27 L. T.

313 ; L. R. 7 C. P. 409 ; 36 J. P. 535 . . $\quad$. 49

Bartram, Richards $v$.

Batt, R.v., (1835) 6 Car. \& P. 329 . $\quad . \quad$. $\quad$. 71

Bauld, R. $v$.

Bedford (Duke of) $v$. Ellis, [1901] A. C. 1 ; 70 L. J. Ch.

102 ; 83 L. T. 686 ; 17 T. L. R. 139 ; 45 S. J. 147176

Belfast Harbour Commissioners, Larkin $v$.

Bennett, Judge $v$.

Blackburn, R. $v$. .

Booth, Knowles $v$.

Booth, Mineral Water Bottle Exchange and Trade Protection Society $v$.

Boots $v$. Grundy, (1900) 82 L. T. 769 ; 16 T. L. R. 457 ; 48 W. R. 638 ; W. N. 142 ; 44 S. J. 552 . .

Bowen $v$. Hall, (1881) 6 Q. B. D. 333 ; 50 L. J. Q. B. 305 ; 44 T. T. 75 ; 29 W. R. $367 ; 45$ J. P. 373 ; W. N. 15 . . . . . . . .

Bowron, Wood $v$.

Bradlaugh $v$. Newdegate, (1883) 11 Q. B. D. 1 ; 52 L. J.

Q. B. $454 ; 31$ W. R. 792

Bristol Trade and Provident Society, Gozney $v$.

Brunswick (Duke of), Gregory $v$.

Bulcock $v$. St. Anne's Master Builders' Federation, (1903)

19 T. I. R. $27 ; 47$ S. J. 23 . 
Bunn, R. $v$.

PAGE

Burke $v$. Amalgamated Society of Dyers, [1906] 2 K. B. $583 ; 75$ L. J. K. B. $533 \quad$ - $\quad 37,38,85,98-101$, 179,180

Bussy $v$. Amalgamated Society of Railway Servants and Bell, (1908) 24 T. L. R. 437 . . . . . $73(b), 74$ Bykerdike, R. $v$. • . $\quad . \quad$. $\quad . \quad$. $\quad . \quad .8,10$

Carr, Watson $v$., Re Durham Miners' Association.

Carrier $v$. Price, In re Amos, [1891] 3 Ch. 159; 60 L. J. Ch. 570 ; 65 L. T. 69 ; 7 T.L. R. 559 ; W. N. 107 ; 35 S. J.529 . . . . . . . 50, 51 Carrington, Elliman $v$.

Chamberlain's Wharf,Ltd. $v$. Smith, [1900] 2 Ch. $605 ; 69$ L. J. Ch. 783 ; 83 I. 'T. $238 ; 16$ T. L. R. $514 ; 49$

W. R. 91 ; 44 S. J. 643 ; W. N. 163 . 10, 23, 137, $138,145,146,152,153,163,164,166$

Chambers, R. $v$. See R. v. Chambers.

Charnock $v$. Court, [1899] 2 Ch. $35 ; 68$ L. J. Ch. 550 ; 80 L. T. $564 ; 63$ J. P. $456 ; 47$ W. R. $633 ; 43$

S. J. 416 ; W. N. 44 . . . . . 67,177 Clarkson $v$. Stuart, (1895) 22 R. (J.) 5 ; 32 S. L. R. 4 ;

1 Adam, 466 . $\quad . \quad . \quad . \quad . \quad . \quad 64,189$

Clemens, R. $v$.

Close, Farrer $v$.

Close, Hornby $v$.

Cole, R. $v$.

Collins $v$. Locke, (1879) 4 App. Cas. $674 ; 48$ L. J. P. C.

$68 ; 41$ L. T. $292 ; 28$ W. R. 189 . . 11, 88, 90, 105

Connol, Rigby $v$.

Connor $v$. Kent. See Curran $v$. Treleaven.

Conway $v$. Wade, [1909] A. C. 506 ; 78 L. J. K. B. 1025 ; 101 L. T. $248 ; 25$ T. I. R. 779 ; 53 S. J. 754 ; W. N. 185 $.58,59,69$

Cope $v$. Crossingham, [1909] 2 Ch. 148 ; 78 L. J. Ch. 615 ; 100 L. T. $945 ; 25$ 'T. L. R. $593 ; 53$ S. J. 559 ; W. N. $125 \quad \cdot \quad \cdot \quad$. $44(b), 153-155,163,179$

Court, Charnock $v$.

Cowie, Kennedy $v$.

Crocker $v$. Knight, [1892] 1 Q. B. 702 ; 61 L. J. Q. B. 466 ; 66 L. T. $596 ; 8$ T. T. R. $412 ; 40$ W. R. 353 ; 56 J. P. $420 ;$ W. N. 47 
Crossingham, Cope $v$.

Cullen $v$. Elwin and Others, (1904) 90 L. T. $840 ; 20$

T. L. R. $490 ; 48$ S. J. 474 • . . 10,93-98, 116

Curle $v$. Lester, (1893) 9 T. L. R. 480 • . . 4 4, 175

Curran $v$. Treleaven, [1891] 2 Q. B. $545 ; 61$ L. J. M. C.

9 ; 65 L. T. $573 ; 7$ T. L. R. 650 ; W. N. 154 . 65, 66

De Francesco $v$. Barnum (No. 1), (1890) 45 Ch. D. 430 ; 59 L. J. Ch. $151 ; 63$ I. T. $514 ; 6$ T. L. R. $59 ; 34$ S. J. 687

Denaby $v$. Cadeby Main Collieries, Ld. $v$. Yorkshire Miners' Association, [1906] A. C. 384 ; 75 L. J. K. B. 961 ;

95 L. T. $561 ; 22$ T. L. R. 543

Druitt, R. $v$.

Duke $v$. Littleboy, (1880) 49 L. J. Ch. $802 ; 43$ L. T.

216 ; 28 W. R. 977 ; W. N. 152 . 133, 134, 142, 164,

Duncombe, Salmon $v$.

165,179

Durham Miners' Association, In re. See Watson $v$. Cann

$37(a), 39$

Eckersley, Hilton $v$.

Edinburgh and District Aerated Water Manufacturers

Defence Association, Ltd. $v$. Jenkinson, (1903) 5

F. $1159 ; 40$ S. L. R. 825 . . . . .

Edmondes, R. $v$.

Elliman, Sons \& Co. v. Carrington, [1901] 2 Ch. 275 ;

70 L. J. Ch. 577 ; 84 L. T. 858 ; 49 W. R. 532 ;

45 S. J. 536 ; W. N. 112

Ellis, Bedford (Duke of) $v$.

Elwin and Others, Cullen $v$.

Farmer $v$. Wilson, (1900) 69 L. J. Q. B. $496 ; 82$ L. T. $566 ; 16$ T. L. R. $309 ; 19$ Cox, C. C. $502 ; 64$ J. P. 486 ; 44 S. J. 363

Farrer v. Close, (1869) 4 Q. B. 602 ; 38 L. J. M. C. 132 ; 20 L. T. 802 ; 10 B. \& S. 533 ; 17 W. R. 1129 ; 33 J. P. 517

Federation of Trades and Labour Unions, Pink $v$.

Flood, Allen $v$.

Free Church of Scotland, McMillan $v$.

Friendly Society of Operative Stonemasons, Read $v$.

Gardiner, Macdougall $v$. 


\section{INDEX TO CASES CITED.}

Garret v. Taylor, (1792) Cro. Jac. 567 ; 2 Roll. Rep. 162 ;

Darr. Ab. 201 . . . . . . .

PAGE

General Union of Operative Carpenters and Joiners, Mudd $v$.

General Union Society of Operative Carpenters and

Joiners $v$. O'Donnel, (1877) 11 Ir. L. T. 282 .
Giblan $v$. National Labourers' Union, [1903] 2 K. B. 600 ; 72 L. J. Q. B. 907 ; 89 L. T. 386 ; 19 T. L. R. 708 ; W. N. 172 . . . . . . .

Gibson $v$. Lawson. See Curran $v$. Treleaven . $\quad 64-66,186$ Glamorgan Coal Co., South Wales Miners' Federation $v$. Glamorgan Coal Co. $v$. South Wales Miners' Federation, [1903] 2 K. B. 545 ; 72 L. J. K. B. 893 ; 89 L. 'i'. 393 ; 19 T. L. R. 701 ; 52 W. R. 165 ; W. N. 152 .

Glasgow Fleshers' Association, Scottish Co-operative Wholesale Society $v$.

Gordon $v$. Pyper, (1893) 20 R. (H. L.) 23

Governors of the Kingston-upon-Hull Corporation, Winder $v$.

Gozney $v$. Bristol Trade and Provident Society, [1909] 1

K. B. 901 ; 78 I. J. K. B. 616 ; 100 L. T. 669 ;

25 T. L. R. 370 ; 53 S. J. 341 ; W. N. 58 . $39,77,78$, $85,86,101-106,110$,

Graves, Horner $v$. $114,116,120,121,174$

Great Central Railway Company, Jones $v$.

Green, Price $v$.

Green, Walters $v$.

Gregory $v$. Brunswick (Duke of), (1843) 6 Man. \& G. 205 ; 13 L. J. C. P. 34 ; 6 Scott, 809 ; 1 D. \& L. 518; 8 Jur. 448 ; Exch. Ch. 16 L. J. C. P. 35 ; 3 C. B. 841

Greig $v$. National Amalgamated Union of Shop Assistants, (1906) 22 T. L. R. 274 . . . . . 178

Grundy, Boots $v$.

Gunther, Vegelahn $v$.

Gye, Lumley $v$.

Haile $v$. Lillingstone, (1891) 55 J. P. 676 ; 35 S. J.

$792 . \quad . \quad . \quad . \quad . \quad .65,72$

Hall, Bowen $v$.

Hart, M‘Kinlay $v$. 
Hewlett, Alfin $v$.

Hibbert and Others, R. $v$.

Hickeringill, Keeble $v$.

Hilton $v$. Eckersley, (1857) 6 E. \& B. 47 ; 25 L. J. Q. B.

$$
199 \text {; } 2 \text { Jur. } 587 \text {; } 4 \text { W. R. } 326 \quad \text {. } \quad 8,10,11,75,88
$$

Hornby $v$. Close, (1867) 2 Q. B. 153 ; 36 L. J. M. C. 43 ;

15 L. T. 563 ; 10 Cox, C. C. 393 ; 8 B. S. 175 ; 15

W. R. 336 ; 31 J. P. 148 ; W. N. 15 . 9, 12, 13, 22,

Horner $v$. Graves, (1831) 7 Bing. 735 . $\quad$. $\quad . \quad$. 111

Howden, Yorkshire Miners' Association $v$.

Huttley $v$. Simmons, [1898] 1 Q. B. $181 ; 67$ L. J. Q. B. 213 ; 14 T. L. R. 150

In re Amos. See Carrier $v$. Price.

In re Durham Miners' Association. See Watson v. Cann. Ingall, Baker and Others $v$.

Ingall, Friendly Society of Ironfounders of England, etc. $v$. See Baker $v$. Ingall.

Jenkinson, Ediuburgh, etc. Defence Association, Itd. $v$. Jenkinson $v$. Nield, (1892) 8 T. L. R. 540 • • $\quad$ • 71

Jones v. Great Central Railway Company, [1910] A. C. 4 . 178 José $v$. Metallic Roofing Company of Canada, [1908] A. C. $514 ; 78$ L. J. P. C. 36 ; 99 L. T. 742 ; 24 T. L. R. 878

Journeymen 'Taylors of Cambridge, R. $v$.

Judge $v$. Bennett, (1887) 36 W. R. 103 ; 52 J. P. 247 . 66

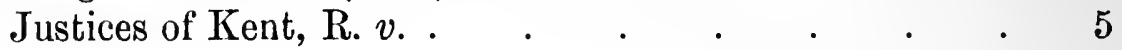

Kearney $v$. Lloyd, (1891) 26 L. R. Ir. 268 . . · 75

Keeble $v$. Hickeringill, (1809) 11 East, 574 . . 56,70

Keep, Norey $v$.

Kennedy $v$. Cowie, [1891] 1 Q. B. $771 ; 60$ L. J. M. C.

170 ; 64 L. T. 598 ; 7 T. L. R. $474 ; 17$ Cox,

C. C. 320 ; 39 W. R. 686 ; 55 J. P. 680 . .

Kent, Connor $v$. See Curran $v$. Treleaven.

Kent (Justices of), R. $v$.

King, Wilkie $v$.

Kingston-upon-Hull Corporation (Governors of),

Winder $v$.

Knight, Crocker $v$. 
PAGE

Knight $v$. Whitmore, (1885) 53 L. T. 233 ; 33 W. R. 907

Knowles $v$. Booth, (1884) 32 W. R. 432 . . $\quad 91,92$

Lancashire and Cheshire Miners' Association, Lees $v$.

Larkin $v$. Belfast Harbour Commissioners, [1908] 2 Ir.

K. B. D. 214

Lawson, Gibson $v$. See Curran $v$. Treleaven.

Leathem, Quinn $v$.

Lees $v$. Lancashire and Cheshire Miners' Association, (1906) Times, June 20th . . $124(b), 178$

Leng \& Co. $v$. Andrews, (1909) $\quad . \quad$ • $\quad . \quad$. $\quad .112$

Lester, Curle $v$.

Linaker $v$. Pilcher, (1901) 84 L. T. $421 ; 70$ L. J. K. B. 396 ; 17 T. L. R. 256 ; 46 W. R. 413 ; 45 S. J. 276

Lillingstone, Haile $v$.

Littleboy, Duke $v$.

Lloyd, Kearney $v$.

Locke, Collins $v$.

London Building Trades Federation, Trollope $v$.

Lothian, Smith $v$.

Lumley $v$. Gye, (1854) 2 E. \& B. 216 ; 22 L. J. Q. B. 463 ; 17 Jur. 827 ; 1 W. R. 432 .

Lushington, Pender $v$.

Lyons $v$. Wilkins (No. 1), [1896] 1 Ch. 811 ; 65 L. J.

Ch. 601 ; 74 L. T. 358 ; 45 W. R. 19 . . 67,76

Lyons $v$. Wilkins (No. 2), [1899] 1 Ch. 255 ; 68 L. J. Ch. 146 ; 79 L. T. 709 ; 15 T. L. R. 128 ; 47 W. R.

$291 ; 63$ J. P. 339 • . . . . 64,67

Lynch, R. $v$.

Macdougall $v$. Gardiner, (1876) 1 Ch. D. 13 ; 45 L. J. Ch.

27 ; 33 L. T. 521 ; 24 W. R. 118 . . . . 152

Mackendrick $v$. National Union of Dock Labourers in Great Britain and Ireland, (1911) S. C. 83 ; 48

S. L. R. 431 . . . . . . . 37,178

Madden $v$. Rhodes, [1906] 1 K. B. 534; 75 L. J. K. B. 329 ; 94 L. T. 741 ; 22 T. L. R. 356 ; 21 Cox, C. C. 180 ; 54 W. R. 373 ; 70 J. P. 230 ; 50 S. J. 326 ;

W. N. 60 . Markham, Barret $v$. 


\section{xiv INDEX TO CASES CITED.}

Matthews, Wolfe $v$.

Maxim Nordenfelt Co., Nordenfelt $v$.

M.Carthy, R. $v$.

McCarthy, Wood $v$.

McElrea $v$. United Society of Drillers, (1905) Times, Feb. 17th . . . . . . .

M'Gawley, Tarleton $v$.

McGregor, Gow \& Co., Mogul Steamship Co. v.

McKeevit, R. $v$.

McKenzie, R. $v$.

M'Kernan $v$. United Operative Masons' Association,

(1874) 1 R. 453 ; 11 S. L. R. 219 . . 14, 127-130, 135,139

M‘Kinlay v. Hart, (1898) 25 R. (J.) 7 ; 35 S. L. R. 32 ;

5 S. L. T. (J.) $197 ; 2$ Adam, 366 • • • • 67

M'Laren v. Miller, (1880) 7 R. 867 ; 17 S. L. R. 607 . 125, $128,133,135,138-143$

M'Millan $v$. The Free Church of Scotland, (1861) 23 D.

1314 ; 33 Jur. 665

Metallic Roofing Company of Canada, José $v$.

Metcalfe $v$. Wiseman, (1888) 52 J. P. $439 \quad$ • $\quad$ • $\quad 189$

Miller, M`Laren $v$.

Mineral Water Bottle Exchange Society $v$. Booth, (1887)

36 Ch. D. 465 ; 57 L. T. 573 ; 3 T. L. R. 740 ; 36

W. R. 274 ; 31 S. J. 703 ; W. N. 174 . 10, 11, $23(a)$

Mitchel $v$. Reynolds, (1711) 1 P. Wms. 181 ; 1 S. L. C.

(11th ed.) 417 ; 10 Mod. 130 ; Fort. 296 . . . 10

Mogul Steamship Co. v. McGregor, Gow \& Co., [1892]

A. C. 25 ; 61 L. J. Q. B. 295 ; 66 L. T. 1 ;

8 T. L. R. $182 ; 40$ W. R. 337 ; 56 J. P. 101 • 10,

$11,71,72,77,78,79$

Moody, Smith $v$.

Motherwell Branch of Amalgamated Society of Railway

Servants, Amalgamated Society of Railway Servants

for Scotland $v$. See M'Laren $v$. Miller.

Mudd $v$. General Union of Operative Carpenters and

Joiners, (1910), 103 L. T. 45 ; 26 T. L. R. 518...116-118

Mullett $v$. United French Polishers' Society, (1905) 91

L. T. 133 ; 20 T. L. R. 595 . • . . $144(a)$

Munro, Agnew $v$.

National Amalgamated Union of Shop Assistants, Greig $v$. 


\section{INDEX TO CASES CITED.}

National Association of Operative Plasterers and Others, Smithies $v$.

National Labourers' Union, Giblan $v$.

National Union of Dock Labourers in Great Britain and Ireland, Mackendrick $v$.

Newdegate, Bradlaugh $v$.

Nield, Jenkinson $v$.

Nordenfelt $v$. Maxim Nordenfelt Co., [1894] A. C. 535 ; 63 L. J. Ch. 908 ; 71 L. T. 489 ; 10 T. L. R. 636 ;

W. N. $151 \quad$ • • • • . ・ 10,11,111

Norey $v$. Keep, [1909] 1 Ch. $561 ; 78$ L. J. Ch. 561 ; 100 L. T. 322 ; 25 T. L. R. 289 . . . . 38

O'Donnel, General Union Society of Operative Carpenters and Joiners $v$.

Old $v$. Robson, (1890) 62 I. T. 282 ; 59 L. J. M. C. 41 ; 6 T. L. R. 151 ; 38 W. R. 415 ; 54 J. P. 597 ; 34

S. J. $197 \quad \cdot \quad 10,24,83,90-93,95,96,98,99,116$

Operative Printers' Society and Another, Ward, Lock \& Co., Ltd. $v$.

Osborne, Amalgamated Society of Railway Servants (No. 1) $v$.

Osborne $v$. Amalgamated Society of Railway Servants (No. 2), [1911] 1 Ch. 540 ; 80 L. J. Ch. 315 ; 104 L. T. 267 ; 27 T. L. R. 289 ; W. N. 59 83, 118-120, $126,128,155-161,165$ (a), 166, 171, 174

Pender $v$. Lushington, (1877) 6 Ch. D. 70 ; 46 L. J. Ch.

317 ; 57 L. T. 353 ; 32 S. J. 68 . . . . 161

Peto $v$. Apperley, (1891) 35 Sol. J. $792 \quad$ • $\quad$ - $\quad 65,72$

Phillips, R. $v$.

Pilcher, Linaker $v$.

Pink $v$. Federation of Trades and Labour Unions, (1893)

67 L. T. 258 ; 8 T. L. R. 216,711 ; 36 S. J. 201 • 71

Poulterer's Case, (1611) 9 Co. Rep. 55 ; S. C. Moor, 813

Price, Carrier $v .$, In re Amos.

Price v. Green, (1847) 16 M. \& W. $346 \quad$ • $\quad$ • $\quad$ - 88

Printers and Transferers Amalgamated Trades Protection Society, In re, [1899], 2 Ch. $184 ; 68$ L. J. Ch. $537 ; 16$ T. L. R. $394 ; 47$ W. R. $619 ; 43$ S. J. 550 ; W. N. 86 • • • • . . 38,157

Pyper, Gordon $v$. 
Quinn $v$. Leathem, [1901] A. C. $495 ; 70$ L. J. P. C. 76 ;

85 L. T. 289 ; 17 T. L. R. 749 ; 50 W. R. $139 ; 65$

J. P. 708 ; W. N. 170 . $\quad . \quad . \quad . \quad .69,71,79$

Read $v$. Friendly Society of Operative Stonemasons, [1902]

2 Q. B. 732 ; 71 L. J. K. B. 994 ; 87 L. T. 493 ;

19 L. R. 20 ; 51 W. R. 115 ; 66 J.P. 822 ; 47 S. J.

29 70,73

Registrar of Friendly Societies, R. $v$.

Renton, Wilson $v$.

R. v. Batt, (1835) 6 Car. \& P. 329.

R. v. Bauld, (1878) 13 Cox, C. C. 282 . . . . 66

R. $v$. Blackburn, (1874) 11 Cox, C. C. 151 . . $\quad$. 13

R. $v$. Bunn, (1875) 12 Cox, C. C. 316 . $\quad$ 9, 10,62(a)

R. $v$. Bykerdike, (1832) 1 M. \& Rob. 179 . . . 8, 10

R. v. Chambers, (1899) 18 Cox, C. C. 401 ; 65 L. J.

M. C. $214 ; 12$ T. L. R. 613 . . . . $181(d)$

R. v. Clemens, [1898] 1 Q. B. 556 ; 67 L. J. Q. B. 482 ;

78 L. T. $594 ; 14$ T. L. R. $273 ; 46$ W. R. $636 ; 42$

S. J. 326

R. v. Cole, (1891) 1 C. C. C. Sess. Papers, 622

67

R. $v$. Druitt, (1868) 10 Cox, C. C. 592 ; 16 L. T. 855 . 10

R. $v$. Edmondes, (1874) 43 L. J. M. C. $156 ; 31$ L. T.

$237 ; 22$ W. R. $944 ; 59$ J. P. 776 . $\quad$. 189

R. $v$. Hibbert and Others, (1878) 13 Cox, C. C. 82 . $62(a), 63$

R. $v$. Journeymen Taylors of Cambridge, (1721) 8 Mod.

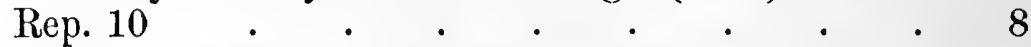

R. v. Justices of Kent, (1812) 14 East, 395 • . . . 5

R. v. Lynch, $[1898] 1$ Q. B. $61 ; 67$ L. J. Q. B. $59 ; 77$

L.T. $568 ; 14$ T. L. R. $78 ; 46$ W. R. $205 ; 8$ Asp.

M. L. C. 363

R. v. M'Carthy, (1903) 2 I. R. $146 \quad$. $\quad . \quad . \quad .65$

R. v. McKeevit, (1891) 2 Q. B. at p. $562 \quad$. $\quad$. $\quad 66$

R. $v$. McKenzie, $[1892] 2$ Q. B. $519 ; 61$ L. J. M. C.

181 ; 67 L. 'I. 201 ; 8 T. L. R. 712 ; 17 Cox, C. C.

542 ; 56 J. P. $484 ; 41$ W. R. $144 ; 36$ S. J. 667 . 67,

188,189

R. $v$. Phillips, (1891) 113 C. C. C. Sess. Papers, 622 • 65

R. $v$. Registrar of Friendly Societies, (1872), 7 Q. B. 741 ;

41 L. J. Q. B. 366 ; 27 L. T. 229 .

31

R. $v$. Rowlands, (1853) 5 Cox, C. C. 466 ; 17 Q. B. 671 ;

21 L. J. M. C. 81 ; 16 Jur. 268 ; 2 Den. C. C. 364 . 


\section{INDEX TO CASES CITED.}

xvii

PAGE

R. v. Selsby, (1853) 5 Cox, C. C. at 495, n. . . . 8

R. v. Stainer, (1870) L. R. 1 C. C. R. 230 ; 39 L. J. M. C. 54 ; 21 L. T. 758 ; 10 B. \& S. 553 ; 18 W. R. 439

13,88

R. $v$. Tankard, [1894] 1 Q. B. 548 . . . . 50

R. $v$. Truscott, (1900) 81 L. T. 188; 19 Cox, 379) . . 48

R. v. Wall, (1890) 112 (\%. C. C. Sess. Papers, 880 . . 65

R. v. Wall, (1910) 21 Cox, C. C. $401 \quad$. $\quad$. $\quad$ 62, 67

Reynolds, Mitchel $v$.

Rhodes, Madden $v$.

Riche, Ashbury Railway Carriage Co. $v$.

Rickards $v$. Bartram, (1909) 25 T. L. R. $181 \quad$. . $\quad$ 7t

Rigby $v$. Connol, (1880) 14 Ch. D. 482 ; 49 L. J. Ch.

328 ; 42 L. T. 139 ; 28 W. R. 650 ; W. N. 36 . 128 , $131-135,137,138,139,142,143,144,145,147$, $149,153,162,163-166,170$

Riley, Springhead Spinning Co. $v$.

River Dee Co., Wenlock $v$.

Robson, Old $v$.

Rowlands, R. $\imath$.

Russell $v$. Amalgamated Society of Carpenters and Joiners,

[1910] 1 K. B. 506 ; 79 L. J. K. B. 507 ; 102 L. T.

$119 ; 26$ T. L. R. 228 ; 54 S. J. 213 . . . 83, 84, 85,

$86,106-117$

Russell, Temperton $v$.

Russell \& Co. $v$. United Suciety of Boilermakers, (1907)

15 S. L. T. 118

Salmon $v$. Duncombe, (1886) 11 App. Cas. 627; 55

L. J. P. C. $69 ; 55$ L. T. 446 . . . . 162

Sayer $v$. Amalgamated Society of Carpenters and Joincrs,

(1903) 19 T. L. R: 122 . . . . . .87, 98, 116

Scotland (Free Church of), McMillan $v$.

Scottish Co-operative Wholesale Society $v$. Glasgow

Fleshers Association, (1898) 35 S. L. R. $645 ; 5$

S. I. T. 336 . . . . . . . . 71

Scottish 'Typographical Association, Wilson $v$.

Selsby, R. $v$.

Shanks $v$. United Operative Masons' Association, (1874)

1 R. 823 ; 11 S. L. R. 356 . . 14, 127, 130, 131,

135,139

T.U. 


\section{xviii INDEX TO CASES CITED.}

PAGE

Simmons, Huttley $v$.

Smith, Aberdeen Master Masons' Incorporation $v$.

Smith, Chamberlain's Wharf, Ltd. $v$.

Smith $v$. Lothian, (1862) Ir. 170 .

Smith $v$. Moody, [1903] 1 K. B. 56 ; 72 L. J. K. B. 43 ;

87 T. T. 682 ; 19 T. L. R. 7 ; 18 Cox, C. C. 161 ;

51 W. R. 252; 67 J. P. 69 . . . . . 189

Smith $v$. Thomasson, (1890) 62 L. T. 68 ; 16 Cox, C. C.

$740 ; 54$ J. P. 596

Smithies $v$. National Association of Operative Plasterers and others, $[1909] 1$ K. B. 310 ; 78 I. J. K. B. 259 ;

100 L. T. $172 ; 25$ T. I. R. 205 . . . $57(b), 78$

Snell $v$. Vine, (1890) F. Soc. Cas. 313 . . . . . 52

South Wales Miners' Federation, Glamorgan Coal Co. $v$.

South Wales Miner's' Federation v. Glamorgan Coal Co.,

[1905] A. C. $239 ; 74$ L. J. K. B. $525 ; 92$ L. 'T.

$710 ; 21$ T. L. R. 441 ; 53 W. R. 593 ; W. N. 7269

South Wales Miners' Federation, Steele $v$.

Springhead Spinning Co. $v$. Riley, (1868) 6 Eq. $551 ; 37$

L. J. Ch. 889 ; 19 L. T. 64 ; 16 W. R. $1138.170(a)$

St. Anne's Master Builders' Federation, Bulcock $v$.

Stainer, R. $v$.

Steele $v$. South Wales Miner's' Federation, [1907] 1 K. B.

$361 ; 76$ L. J. K. B. $333 ; 96$ L. T. $260 ; 23$

T. L. R. 228 . . . . . . . $37,38,152,153$

Stevenson, United Builders Labourers' Union $v$.

Strick $v$. Swansea 'Tinplate Co., (1887) 36 Ch. D. 558 ;

57 I. J. Ch. 438 ; 57 L. T. 392 ; 35 W. R.

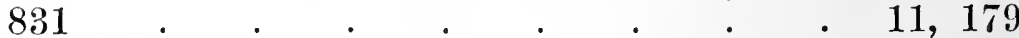

Stuart, Clarkson $v$.

Swaine $v$. Wilson, (1889) 29 Q. B. D. 252 ; 59 L. J. Q. B.

76 ; 62 L. T. 309 ; 38 W. R. 261 ; 54 J. P. $484 \ldots 10,11$, $24,83,84,87-90,92-100,102,105,106$, $110,113,116,120,125$

Swansea Tinplate Co., Strick $v$.

'Taff Vale Railway Co. $v$. Amalgamated Society of Railway Servants, [1901] A. C. 426 ; 70 L. J. K. B. 905 ; 85 L. T. 147 ; 17 T. L. R. 698 ; 65 J. P. 596 ; 50 W. R. 44 . . $17,44,48,73,168,174,175$ Tallis $v$. Tallis, (1852) 21 L. J. Q. B. 269 ; 1 E. \& B. 397, n. ; 16 Jur. 744 . $\quad . \quad$ • . $\quad . \quad$. 88 
Tankard, R. $v$.

Tarleton $v$. M‘Gawley, (1793), 1 Peake, 270; 3 R. R. 689

Taylor, Garret $v$.

Temperton $v$. Russell, [1893] 1 Q. B. $715 ; 62$ L. J. Q. B. 412 ; 69 L. T. 78 ; 41 W. R. 565 ; 57 J. P. 676 . 69,

Thomasson, Smith $v$.

Treleaven, Curran $v$.

Trollope $v$. London Building Trades Federation, (1895) 72 L. T. 342 ; 11 T, L. R. 280 ; W. N. 45 . 65, 71 Truscott, R. $v$.

Underwood and Sons $v$. Baker, [1899] 1 Ch. $300 ; 68$ L. J. Ch. $201 ; 80$ T. T. 306 ; 15 T. L. R. $177 ; 47$ W. R. 347 . . . . . . . . . . 111

United Builders' Labourers' Union $v$. Stevenson, (1906) Times, Feb. 7 . . . . . . .

United French Polishers' Society, Mullett $v$.

United French Polishers' Society, Wallis $v$.

United Operative Masons' Association, M'Kernan $v$.

United Operative Masons' Association, Shanks $v$.

United Society of Boilermakers, Russell $v$.

United Society of Drillers, McElrea $v$.

Urmston v. Whitelegg Brothers, (1891) 63 L. T. 455 (Div. Ct.) ; 55 J. P. 453 (C. A.) . . . . 11

Vegelahn $v$. Gunther, (1896) 167 Mass. $92 \quad$. . . $\quad 66$

Vine, Snell $v$.

Wade, Conway $v$.

Wall, R. v., (1890)

Wall, R. v., (1910)

Wallis $v$. United Erench Polisher's' Society, (1905) T'imes, Nor. 28 . . . . . . .

Walsby \%. Auley, (1861) 30 L. J. M. C. 121 ; 3 L. 'T. $666 ; 9$ W. R. $271 ; 7$ Jur. 465. . . . 9, 76

Walters $v$. Green, [1899] 2 Ch. 696 ; 68 I..J. Cn. 730 ; 81. L. T. 151 ; 15 T. L. R. $532 ; 48$ W. R. 23 ; 63 J. P. 742 ; W. N. 138 . . . . . 67,177

Ward, Lock \& Co., Ltd. v. Operative Printers' Society and Another, (1906) 22 T, I. R. 327 . . . . 64 
Watson v. Carr; In re Durham Miners' Association,

PAGE

(1901), 17 T. L. R. 39 . . . . . . 37 (a), 39

Wenlock v. River Dee Co., (1885) I. R. 10 App. Cas.

362 ; 53 L. J. Q. B. 208 ; 49 L. T. 617 ; 32 W.R. 22026

Whitelegg, Urmston $v$.

Whitmore, Knight $v$.

Wilkie $v$. King, (1911) 2 S. L. T. 206 ; 48 S. L. R. 1057125

Wilkins, Ex parte, 64 L. J. 221 ; 72 L. T. 567 ; 18 Cox, C. C. $161 ; 59$ J. P. 294

Wilkins, Lyons $v$. (Nos. 1 and 2).

Wilson $v$. Amalgamated Society of Engineers and Others, [1911] 2 Ch. $324 ; 80$ L. J. Ch. $469 ; 104$ L. T. $715 ; 27$ T. L. R. $418 ; 55$ S. J. 498

Wilson, Farmer $v$.

Wilson $v$. Renton, (1909) 47 S. L. R. 209 • • $\quad$ • 64

Wilson $v$. Scottish Typographical Association, (1911) 1

S. L. T. 253 .

19,169

Wilson, Swaine $v$.

Winder $v$. Governors of the Kingston-upon-Hull Corporation, (1888) 20 Q. B. D. 412 ; 58 L. T. 583 ; 52 J. P. $535 ;$ W. N. 12

Wiseman, Metcalf $v$.

Wolfe $v$. Matthews (1882), 21 Ch. D. $194 ; 51$ L. J. Ch.

$833 ; 47$ L. T. 158 ; 30 W. R. 838 ; W. N. 113...29, 41, $135,142,143,144,147,155,162,163$

Wood $v$. Bowron, (1867) L. R. 2 Q. B. 21 ; 36 L. J. M. C. 5 ; 15 L. T. 207 ; 7 B. \& S. 931 ; 15 W. R. 58 . 66

Wood $v$. McCarthy, [1893] 1 Q. B. $775 ; 62$ L. J. Q. B. 373 ; 69 L. T. 431 ; 9 T. L. R. 447 ; 41 W. R. 523 ; 37 S. J. 478 ; W. N. 85

Yorkshire Miners' Association, Denaby and Cadeby Main Collieries, Ltd. $v$.

Yorkshire Miners' Association v. Howden, [1905] A. C. $256 ; 74$ L. J. K. B. $511 ; 92$ L. T. $701 ; 21$ 'I'. L. R. 431 ; 53 W. R. 667 ; W. N. 72. C. A., [1903] 1 K. B. $308 ; 72$ I. J. K. B. $176 ; 88$ L. T. $134 ; 19$ 'T. I. R. 193 ; 47 S. J. 237 ; W. N. 17 . 44, 82, 126, $128,143-152,153,155,162$, $163,165,175,176,178$ 


\section{ABBREVIATIONS.}

\section{ENGLAND.}

Asp. M. L. C. . . Aspinall's Maritime Law Cases.

Car. \&.P. . . . Carrington \& Payne's Reports.

C. C. C. Sess. Papers - Central Criminal Court (Session Papers).

Co. Rep. . . . Coke's Reports.

Cox, C. C. . . . Cox's Criminal Cases.

Cro. Jac. . . . Croke's Reports.

Den. C. C. . . . Denison's Crown Cases.

E. \& B. . . . Ellis \& Blackburn.

F. Soc. Cas. . . . Diprose \& Gammon's Friendly Society Cases.

J. P. . . . . Justice of the Peace.

I. J. . . . . Law Journal.

L. R. . . . . Law Reports.

L. T. . . . . Law Times.

Man. \& G. . . . Manning \& Grainger's Reports.

M. \& Rob. . . . Moody \& Robinson.

M. \& W. . . . Meeson \& Welsby.

P. Wms. . . . Peere Williams' Reports.

S. J. . . . . . Solicitors' Journal.

T. L. R. . . . Times Law Reporter.

W. N. . . . Weekly Notes.

IV. R. . . . . Weekly Reporter.

\section{SCO'TLAND.}

Adam . . . . Adams' Reports, Justiciary Courts of Scotland.

D. . . . . Dunlop.

Cowp. . . . . Cowper's Scottish Justiciary Cases,

F. : : : : Fraser, 
xxii

R. . . . . Rettie.

S. C. . . . . . Session Cases.

S. L. R. . . . . Scottish Law Reporter.

S. L. T. . . . Scots Law Times.

White · . . . White's Reports, Justiciary Courts of Scotland.

\section{IRELAND.}

Ir. L. R. Irish Law Reports.

Ir. L. T. . . . Irish Law Times. 


\section{INDEX TO STATUTES CITED.}

(1305) $33 \mathrm{Edw}$. I.

PAGE

(1349) 23 Edw. III. st. 1 (Statute of Labourers) . . 2

(1350) 25 Edw. III. st. 2 (Statute of Labourers) . . 2

(1388) 12 Rich. II. cc. 3-9 (Labourers) . . . 2

(1389) 13 Rich. II. c. 8 (Labourers) . . . . . 2,3

(1405) 7 Hen. IV. c. 17 . . . . . . . 2

(1414) 2 Hen. V. c. 4 . $\quad$. $\quad$. $\quad . \quad$. $\quad . \quad$. 2

(1425) 3 Hen. VI. c. 1 (Labourers) . . . . . 5

(1426) Jac. I. c. 4 (of the Fee of Werkmen) . . . 2

(1427) 6 Hen. VI. c. 3 . . . . . . . 2

(1512) 4 Hen. VIII. c. 5 (Wages of Labourers) . 2, 3

(1514) 6 Hen. VIII. c. $3 \quad$. $\quad$. $\quad$. $\quad . \quad$. $\quad$. 2

(1548) 2 \& 3 Edw. VI. c. 3 (Purveyors) . . . 5

(1562) 5 Eliz. c. 4 (Statute of Apprentices) . . . 3

(1662) 14 Chas. II. c. 15 (Silk Throwers) . $\quad$ • $\quad$ • 6

(1720) 7 Geo. I. c. 13 . $\quad$. $\quad . \quad$. $\quad . \quad$. 6

(1746) 20 Geo. II. c. 43 [Heritable Jurisdictions (Scotland) Act $] . \quad . \quad . \quad . \quad . \quad . \quad . \quad . \quad 188$

(1756) 30 Geo. II.c. 12 . . . . . . . 4

(1777) 18 Geo. III. c. 55 . . . . . . . 5

(1799) 39 Geo. III. c. 19 (Unlawful Clubs) . . . . 10

(1799) 39 Geo. III. c. 81 (Unlawful Combinations of Workmen Act) $\quad$. $\quad$. $\quad$. $\quad$. $\quad$. $\quad$. $\quad$. $\quad 6$

(1800) $39 \& 40$ Geo. III. c. 106 (Unlawful Combinations

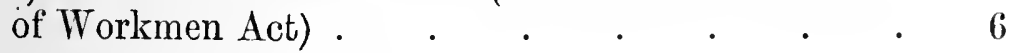

(1801) 41 Geo. III. c. 38 . $\quad$. $\quad$. $\quad$. $\quad$. 4

(1813) 53 Geo. III. c. 40 (Wages of Artificers Act) . 5

(1814) 54 Geo. III. c. 96 (Apprentices' Act) . . . . 5

(1817) 57 Geo. III. c. 19 (Unlawful Clubs) . . . 10

(1824) 5 Geo. IV. c. 95 (Combination of Workmen Act) 7

(1825) 6 Geo. IV. c. 129 (Combination of Workmen Act) 7, 8 (1837) 1 Vict. c. 41 [Small Debts (Scotland) Act] . . 180 
(1855) 18 \& 19 Viat.

(1855) $18 \& 19$ Vict. c. 63 (Friendly Societies Act) . 12

(1859) 22 Vict. c. 34 (Molestation of Workmen Act) . 8

(1861) 24 \& 25 Vict. c. 94 (Accessories and Abettors

Act) . . . . . . . . . 68

(1861) $24 \& 25$ Vict. c. 97 (Malicious Damage Act) $\quad 67,68$

(1868) 31 \& 32 Vict. (. 116 (Larceny Act) . . 13,50

(1869) 32 \& 33 Vict. c. 61 (Trade Union Funds Protection Act) . . . . . . . . 13

(1871) 34 \& 35 Vict. c. 31 ('The 'Trade Union Act) . 9 ,

$11,13,22,24,28-34,36,38-40,42-$

$44,46-48,50,75,81,82,100,118,123$,

$124,129,168,175,179,181-188,191-203$

(1871) $34 \& 35$ Vict. c. 32 (Trade Union Act) . $\quad$. 9

(1875) 38 \& 39 Vict. c. 24 (The Falsification of Accounts

Act) . . . . . . . . . $49(a)$

(1875) $38 \& 39$ Vict. c. 60 (Friendly Societies Acts) . 91

(1875) 38 \& 39 Vict. c. 86 (Conspiracy and Protection

of Property Act) . $\quad . \quad 9,10,61-63,67,68,75$,

$181-189,203-215$

(1876) $39 \& 40$ Vict. c. 22 [Trade Union Act (Amendment) Act] .

$2,21,25,30,33,36,38,40$, $43,44,46,48,52,55,215-220$

(1879) $42 \& 43$ Vict. c. 49 (Summary Jurisdiction) 68, $181-189$

(1883) $46 \& 47$ Vict. c. 47 (Provident Nominations and

Small Intestacies Act) . . . . . 52, 53

(1884) $47 \& 48$ Vict. c. 43 (Summary Jurisdiction) · 181-189

(1893) $56 \& 57$ Vict. c. 2 ('Trade Union Provident Funds

Act) . . . . . . . . 51,221

(1894) $57 \& 58$ Vict. c. 60 (Merchant Shipping Act) . 65

(1896) $59 \& 60$ Vict. c. 25 (Friendly Societies Act). $\quad 25,33$, $39,51,52$

(1906) 6 Edw. VII. c. 38 (Statutory Revision) . . 2 (1906) 6 Edw. VII. c. 47 ('Trade Disputes Act) • 10, 58, $60,61,68,73,75,222,223$

(1908) 8 Edw. VII. c. 49 (Companies Consolidation Act) 23 (1909) 9 Edw. VII. c. 49 (Assurance Companies Act) . 24

(1910) 10 Edw. VII. c. 8 [Finance (1909-10) Act] . 51

(1911) 1 \& 2 Geo. V. c. 55 (National Insurance Act) . . . . . . . $29,256,257$ 


\section{THE LEGAL POSITION OF TRADE UNIONS.}

\section{CHAPTER I.}

INTRODUCTORY.

Before the Trade Union Act, 1871.

To understand the present position of trade unions in English law, it is necessary, in the first Early place, to consider their historical development.

The craft guilds of the middle ages were empowered by the sovereign to lay down the conditions under which persons might practise a trade. They excluded persons who were not members of the guild from working and insisted on a seven years' apprenticeship as a condition of admission, and all this they did lawfully, acting under royal charters. The emancipation of the serfs in Edward III.'s reign increased the competition in the labour market and, as the guilds had now become severely exclusive, the freedmen, thereby liberated, were compelled to sell their labour to those organisations.

In the middle of the fourteenth century, two million persons died of the "black death" - a half of the population-and the scarcity of labour thus T.U. 
produced had far-reaching economic effects. Food rose in price, and higher wages were consequently demanded by the proletarian non-guild workmen. As a result was passed the Statutes of Labourers of 1349 and $1350(a)$, which attempted to fix the wages of all workmen, but in practice operated only in the agricultural and building trades. This statutory determination of wages was limited in its operation to the summer months, and placed the responsibility of fixing them in the winter on the justices of the peace. The labourer, who, since his liberation from serfdom, had been wandering about the country offering his services to the trader or guild who would pay the highest price, was once more tied to the soil., He was ordered by the statute to remain in his parish, under a penalty of imprisonment. To refuse work was an offence, as also was receiving or offering higher wages than were fixed by the statute.

The craft guilds followed the example of Parliament and laid it down that "nobody shall take for working in the said trades more than they were wont heretofore." Many other statutes fixing wages followed the Statute of Labourers $(b)$, until, in 1512, an Act was passed, relieving a master from the obligation to pay the statutory wage above referred to. This Act, in the fourth year of Henry VIII., says : "No penalties for giving of

(a) (1349) 23 Edw. III. st. 1 ; (1350) 25 Edw. III. st. 2 .

(b) Notably (1388) 12 Rich. II. c. 3-9 ; (1389) 13 Rich. II. c. 8 ; (1405) 7 Hen. IV. c. 17 ; (1414) 2 Hen. V. c. 4 ; (1427) 6 Hen. VI. c. 3 ; (1514) 6 Hen. VIII. c. 3 . A similar statute in Scotland is (1426) Jac. I. cap. 4, "of the fee of workmen," repealed in 1906, 6 Edw. VII. c. 38. 
wages under the statute 12 Rich. II. or any other statute shall be imposed on the master or giver of wages" $(a)$.

The next statute of importance was the Statute of Apprentices (b), which resulted from the "suppression of the monasteries by Henry VIII., which led to a large number of unemployed persons wandering about the country" $(c)$.

This Act was passed "in great hope," says the preamble, "that being duly executed, it shall banish idleness, advance husbandry, and yield unto the hired person, both in the time of scarcity and in the time of plenty, a convenient proportion of wages." The Act, among many other provisions (besides confirming the former ones regulating work and wages), fixed hours of labour, and required a testimonial from a master that a servant had completed his work for him, before the servant sought fresh work in a new district. The typical ordinances of the guild were enacted in minute detail in a comprehensive statute, applying to the greater part of the industry of the period $(d)$.

Thus, in 1685, the justices of Warwickshire, in the exercise of the power entrusted to them by the eighteenth Elizabethan Act, fixed, at their quarter sessions, a scale of wages for the county, and notified that every employer who gave more than the authorized sum, and every working man who received more, would be liable to punishment. In Suffolk, Devon-

(a) (1512) 4 Hen. VIII. c. 5. Labour, 1875.

$\begin{array}{ll}\text { (b) (1562) } 5 \text { Eliz. c. } 4 . & \text { (d) " History of Trade }\end{array}$

(c) Royal Commission on Unionism," S. \& B. Webb.

The Eliza-

bethan

Statute of Apprentices.

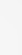


shire and other counties wages were similarly fixed during the seventeenth century. In 1756 an Act was passed to "ratify" piece work wages for clothiers $(a)$.

By 1766, however, the fixing of wages by justices of the peace had fallen entirely into disuse $(b)$. "We may safely assert, that at the close of the eighteenth century, state control had in general become superseded by individual bargaining, and the relationship of master and servant had become contractual" $(c)$. The consequences of this change were that workmen, who had formerly resisted the state regulation of labour, now began to petition Parliament for the enforcement of the Statute of Apprentices, for it was recognised by them that the very state regulation of labour of which they had formerly complained would now be a protection to them in preventing the free competition of unapprenticed men, and of women and children $(d)$.

In 1773 the Spitalfields silk weavers obtained the passing of an Act which ordered the justices to fix the rate of wages in their trade $(e)$. About 1800, the trade societies, which had been formed in many trades to attain what the Statute

(a) (1756) 30 Geo. II. c. 12 ; Macaulay, "History of England," Chapter III. An assessment made in 1725 was published at the end of the century as a curiosity.

(b) "Wealth of Nations," Adam Smith.

(c) "Law of Emplojer and Workman in England," Ruegg.

(d) In 1720 complaint was made to Parliament that journeymen Taylors had combined to raise wages; as a consequence an Act was passed in that year fixing wages in that trade. In 1744 and 1766 complaints were made that the 1720 Act was not being observed.

(e) Confirmed in 1801, 41 Geo. III. c. 38 . In 1778 the Midland Association of Framework Kuitters (a large trade uniop) petitioned Parliament to fix wages. 
of Apprentices had ceased to accomplish (namely, the limitation of apprentices and the fixing of a minimum wage), such as the curriers, hatters, wool staplers, brush makers, calico printers, etc., commenced to bring actions and petition Parliament to enforce the Elizabethan Act. The Courts, however, held that industries which were not in existence in 1563 were outside the scope of the Act, and that the enforcement of the wages was not a duty, but in the discretion, of the justices. ${ }^{1}$ This decision virtually repealed the Statute of Apprentices, as, of course, the justices refused to fix the rate. In 1813, consequently, the sections of the Statute of Apprentices as to fixing wages were repealed $(a)$.

Until the operative sections of the Statute of Apprentices were repealed, Acts restricting combinations of workmen to increase wages, or shorten hours, or better the conditions of their work may be said to have been the necessary corollary of the State fixing their remuneration. But the "Combination Acts," as they were called, which were expressly directed against these combinations, endured much longer than the State regulation of labour. Indeed, there were but few Acts forbidding the combination of workmen prior to the nineteentt century $(b)$. Combinations, however, to enforce the

1 R. v. The Justices of Kent, (1811) 14 East, 395.

(a) (1813) ธ̃3 Geo. III. c. 40 ; (1814) 54 Geo. III. c. 96 . Statutory fixing of wages in the hat trade had been repealed in 1777 , 18 Geo. III. c. 55.

(b) These were (1305) 33 Edw. I., forbidding all con- spiracies; (1425) 3 Henry VI. c. 1, applying to combinations among masons; (15+8) 2 \& 3 Edw. VI. c. 3, "an Act forbidding combinations to raise the price of provisions, applied, thinks Ruegg, to " all 
law, that is, to invoke the Statute of Apprentices, were still considered legal. The above-mentioned Spitalfields Act was thus obtained. Such combinations existed until about 1813. But with regard to all other combinations, not only the statutes above mentioned, but the common law doctrine of "restraint of trade" constituted illegal all combinations of workmen to regulate the conditions of their work $(a)$.

Criminal liabilities of trade unions. Combination Acts.

In 1799 all combinations were made illegal by statute (b), and in 1800 this Combination Act was re-affirmed and codified $(c)$. Thus, in the words of Lord Jeffrey, "a single master was at liberty at any time to turn off the whole of his workmen. But it was made an offence for the whole of the workmen to leave that master at once, if he refused to give the wages they chose to require." Though the Act applied equally to combinations of masters and workmen, "there is no case on record during this period in which an employer was prosecuted" $(d)$.

By the Combination Act of 1800 (c), every combination for obtaining an advance in wages, or altering the hours of work, or decreasing the amount of work, or preventing any person employing whomsoever he might think fit to employ, or for preventing workmen hiring themselves, or attempting to induce combinations amongst labourers for the purpose of regulating the laws and conditions of their work"; (1662) 14 Charles II. c. 15, which, however, referred to master silk throwers rather than workmen; and (1720) 7 Geo. I. c. 13. As to the present law relating to combinations, vide
Chapter III.

(a) As to the present law relating to restraint of trade, vide Chapter IV.

(b) (1799) 39 Groo. III. c. 81.

(c) (1800) $39 \& 40$ Geo. III. c. 106 .

(d) " History of Trade Unionism," S. \& B. Webb. 


\section{INTRODUCTORY.}

workmen to leave their work, was declared illegal ; so also was attending any meeting, called to advance any of these objects, or spending money for the furtherance of such purposes or any of them $(a)$, and imprisonment for three months could be inflicted by the justices for offending against the Act $(b)$.

In 1824, however, was passed the Combination Laws Repeal Act $(c)$, which removed all criminal liability of combinations in advancing or fixing the rate of wages or altering the hours or quantity of work imposed either by statute or common law. The effects of this statute would certainly have included an immunity even for personal violence, threats, or intimidation. In 1825, an amending and qualifying Act was passed ; by it, the combination laws indeed remained repealed, but two new offences, "molestation and obstruction," were created $(d)$.

The immunity of combinations of workmen established by the 1824 Act (making them no longer liable to be prosecuted as associations acting in restraint of trade, save for meetings to discuss wages or hours of work) was removed. 'Thus, after 1825, workmen might still be prosecuted for conspiring in combination.

Conspiracy being thus the only combination liable to prosecution after 1825 , the attention of the Courts was drawn more closely to its nature. Convictions for conspiracy with others to raise wages
(a) Ss. 4-6.
(b) Ibid., s. 2.
(d) (1825) 6 Geo. IV. c. 129.
(c) (1824)5 Geo. IV. c. 95, s.2. As to the present law relating to intimidation, etc., vide Chapter III. 
at common law before 1825 are rare $(a)$. But in 1832 members of trade unions were indicted for illegal combination under the 1825 Act, merely for writing to their employers that a strike would take place. $^{1}$ In 1837 occurred the famous trial of the five Glasgow cotton spinners, for conspiracy, resulting in their conviction $(b)$. In 1846, the officers of the Journeymen Steam Engine, etc., Friendly Society were indicted for conspiracy. The indictment contained 4,914 counts, and resulted in the conviction of nine of the officers. ${ }^{2}$ In 1856, Crompton, J., said that all combinations tending directly to impede and interfere with the free course of trade were not only illegal, but criminal. ${ }^{3}$

In 1859 an Act was passed defining more closely the statutory offences of molestation and obstruction created by the Act of 1825 . It rendered peaceful persuasion to induce workmen to abstain from working, in order to raise their wages, lawful $(c)$. In 1867, the Court of Queen's Bench, for the first time, distinguished between the criminal and civil aspects of combinations generally. "I am very far from saying," said Cockburn, C.J., "that the members of a trade union, constituted for the purpose not to work, except under certain conditions, and to support one another in the event of being ${ }^{1} R$. v. Bykerdike, (1832) 1 C. C. $495(n)$.

M. and Rob. 179.

2 R. v. Selsby, (1851) 5 Cox, 6 E. \& B. 47.

${ }^{3}$ Hilton v. Eckersley, (185̃6)

(a) An instance is the case of Cotton Spinners." T. Marshall, R. v. Journeymen Taylors of Glasgow, 1838.

Cambridge,(1721) 8 Mod. Rep. 10.

(b) "Trial of the Glasgow

(c) Molestation of Workmen Act (1859), 22 Vict. c. 34. 
thrown out of employment, in carrying out the views of the majority. would bring themselves within the criminal law, but the rules of the society would certainly operate in restraint of trade, and therefore, in that sense, be unlawful."

Following this distinction, in 1871 it was enacted by section 2 of the Trade Union Act that the Union, 1871. purposes of a trade union shall not, by reason merely that they are in restraint of trade, be deemed to be unlawful, so as to render any member of such trade union liable to criminal prosecution for conspiracy or otherwise (a). By another Act, passed in the same year, molestation and obstruction were again defined and limited $(b)$, but, in R. v. Bumn and Others, ${ }^{2}$ Brett, J. (Lord Esher), ruled that it had not affected the common law which was not confined to the acts forbidden by that statute. "This decision," said Sir J. Stephen, "caused great dissatisfaction, and probably was the chief cause which led to the passing of the Conspiracy and Protection of Property Act, 1875 " (c).

This Act, by section 3, declared that "no concombination amongst members of trade unions to do any act in furtherance of a trade dispute shall spiracy and Protection of Property be indictable as a conspiracy, unless such act, if Act, 1875, committed by one person, would be punishable as a crime." Since the Poulterer's Case ${ }^{3}$ it had been

1 Hornby v. Close, (1867) 2 L. J. M. O. 121.

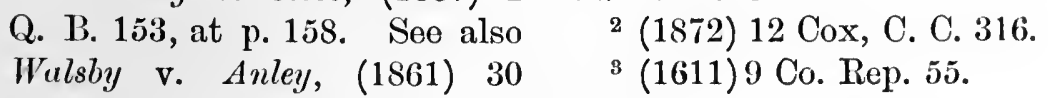

(a) (1871) 34 \& 35 Vict. c. 31 , s. 2 .

(b) (1871) $34 \& 35$ Vict. c. 32. (c) "History of Criminal Law," Stephen; (1875) 38 \& 39 Vict.

c. 86 . See also, infra, p. 62. 
held that the offence of conspiracy might be perpetrated by an agreement between parties to commit an offence, and, in the eighteenth century, it was further considered that a conspiracy might become criminal, even when its original purpose would not be criminal ; in other words, it was held that what was not criminal if done by one person, might become so if several persons agreed to do it $(a)$; and, as well as $R$. v. Bunn above mentioned, the earlier cases of $R$. v. Bykerdike ${ }^{1}$ and $R$. v. Druitt ${ }^{2}$ approved this doctrine. The Act of 1875 rendered trade unions immune from many but not all the consequences of these decisions (b). In 1906, following the Royal Commission on Labour Disputes, by the Trade Disputes Act, further immunities were created $(c)$.

Civil

liabilities of trade unions.

Apart, however, from the question of criminal liability, on the side of civil liability, the agreements of trade unions had long been held unlawful as being contrary to public policy, as being in "restraint of trade" $(d)$. It was decided as early as the reign of Henry V. that a contract imposing a general restraint on trade was void. ${ }^{3}$ No general

1 (1832) 1 M. \& Rob. 179.

${ }^{2}$ (1867) 10 Cox, C. C. 592.

3 Mitchel v. Reynolds, (1711) 1

(a) " Law of Criminal Conspiracies," Wright.

(b) It is still apparently unlawful for any association to employ delegates to meet any other association to persuade the members of the latter society to join the former. 'The prosecution can only be instigated by the Attorney-General. The punish.
Sm. I. Cas. 406 (11th ed.); Hilton v. Eckersley, (18506) 6 E. \& B. 47 ; Mineral Water, etc., Protection

ment is seven years' penal servitude. The Acts, (1799) 39 Geo. III. c. 79 and (1817) 57 Geo. III. c. 19, imposing these penalties are, however, obsolete, (c) (1906) $6 \mathrm{Edw}$. VII. c. 47, vide Chapter III.

(d) As to the present law relating to Restraint of Trade, vide Chapter IV. 
rule has been laid down as to what amounts to restraint of trade. "The question to be decided is whether the restraint exceeds what is reasonable." 1

But among those agreements which are unenforceable at common law, by reason of being in restraint of trade, are those of trade unions, for it has been laid down that agreements between masters not to give employment, or between workmen not to take it except upon fixed terms, being restraints upon trade, are as a general rule not enforceable ${ }^{2}$ between parties to such agreements. On the other hand, rules for the protection of the legitimate interests of the members of an association, where such rules go no further than are reasonably necessary for that purpose, have been held not to be in themselves illegal, and may be enforced, though to some extent in restraint of trade. ${ }^{3}$ The Act of 1871 declared that the purposes of a trade union, by reason merely that they are in restraint of trade, are not deemed to be unlawful so as to render void or voidable any agreement or trust $(a)$.

Society v. Booth, (1887) 36 Ch. D. 465 ; Swaine v. Wilson, (1889) 29 Q.B. D. 252; Old v. Robson,(1890) 59 L. J. M. C. 41 ; Mogul S.S. Co. v. McGreyor, [1892] A. C. 25; Nordenfelt v. Maxim \& Co., [1894] A. C. ๖35 ; Chamberlain's Wharf,Ltd.v.s'mith, [1900] $2 \mathrm{Ch}$. 605 ; Cullen v. Elwin and Others, (1904) 90 L. T. 340.

1 Nordenfelt v. Maxim Nordenfelt Co., [1894] A. C. 535.

2 Hilton v. Lckersley,(1856) $6 \mathrm{H}$. \& B. 47, 66, 75; see also Morgul
S.S. Co.v. McGregor, [1892] A.C. 25.

3 But the Courts may refuse to enforce them on some other ground, ville Chapter V.; see also Collins v. Locke, (1878) 4 App. Cas. 670 ; Mineral Water Society v. Booth, (1S87) $36 \mathrm{Ch}$. D. 465 ; Strick v. Swansea Tinplate Co., ilid., ōss; Swaine v. Wilson, (1889) 24 Q. B. D. 252 ; Urmston v. Whiteleg! Bros., (1890) 63 T. T. 455 ; Lilliman v. Carrington, [1901] 2 Ch. 27 .

(a) (1871) $34 \& 35$ Vict. c. 31 , s. 3. 
Trade union funds.

In addition to these positive restrictions, prior to the Act of 1871 trade unions were placed in considerable difficulty in protecting their funds. One of the results of their status of illegality was that all resort to the Courts for the purpose of preserving or recovering their property or funds was denied to them. A person might steal the money or property belonging to a trade union with impunity. Their bankers or agents could refuse to deliver up the moneys entrusted to them by, or received on account of, the union, and there was no redress $(a)$. It is true that the Friendly Societies Act of $1855(b)$ declared, by section 24 (as applied by section 44), that a society, established for any purpose not illegal, by depositing its rules with the Registrar of Friendly Societies, might have disputes among members summarily dealt with by justices of the peace. In Hornby v. Close, ${ }^{1}$ however, decided in 1867 , it was held that a society, of which one of the objects was the relief of sick, disabled, and aged members, but of which one of the main objects was that of a trade union and the support of members on strike, was not within the 1855 Act, as being in existence, inter alia, for an illegal purpose. Farrer v. Close, ${ }^{2}$ originating like IIornby's case in an accusation by the society that a member had embezzled the funds, was similarly decided, though, in the former case, the Court unanimously upheld the magistrates' refusal to

(1867) 2 Q. B. 153.

${ }^{2}$ (1869) 4 Q. B. 602.

(a) "Tsaw of Employer and Workman in England," Ruegg.

(b) $(1855) 18 \& 19$ Vict. c. 63 , s. 44. 
entertain the proceeding, and, in the latter, the Court was equally divided, in consequence of which the judgment in Hornby's case remained the law.

In 1868, an Act had been passed authorising prosecutions by joint owners of property against one another for larceny $(a)$, and the case of $R$. v. Blackburn ${ }^{1}$ decided that the Act could be used by members of trade unions. No funds, however, could be recovered from the defaulting member, though he could be prosecuted criminally. In 1869, by the Trade Union Funds Protection Act $(b)$, the decision in Hornby v. Close was negatived, and trade unions were expressly placed within the provisions of sections 24 and 44 of the Friendly Societies Act, $1855(c)$.

In the same year a Royal Commission, which had been appointed to enquire into trade unions generally, issued its report. It was recommended that trade unions should be legalised, and a minority report 1868-9. (subscribed by Lord Lichfield and Messrs. Frederick Harrison and Hughes) further recommended that trade unions should be given some legal status, and that they should not be deemed to be illegal by virtue of their acting in restraint of trade, while at the same time the Courts were to be restrained

$$
{ }^{1} \text { (1868) } 11 \text { Cox, C. C. } 157 .
$$

(a) (1868) 31 \& 32 Vict. c. 116.

(b) (1869) $32 \& 33$ Vict. c. 61.

(c) This provision, having become unnecessary owing to the protection granted to registered trade unions by the Act of 1871, was inferentially repealed by the 5th section of that Act. But all rights under the Act of 1869 were, by s. 24 of the 1871 Act, expressly preserved. Vide R. v. Stainer, (1870) L. R. 1 C. C. R. 230. 
from interfering in purely domestic inter-union matters $(a)$. On this recommendation, as to the restriction of the jurisdiction of the Court, which was embodied in section 4 of the 1871 Act, the Lord Justice Clerk (Lord Moncreiff) observed ${ }^{1}$ : "When we see the history of the previous proceedings in the report of the Commissioners, it is quite clear that it was the intention of the Legislature to arrive at this, that the taint of illegality in respect of restraint of trade was to be entirely and absolutely removed, but that the question of enforcement in Courts of law was to be matter of positive statutory enactment." In Shanks v. The United Operative Masons' Association, ${ }^{2}$ Lord President Inglis remarked as follows: "It appears to me that trade unions were unlawful associations before the passing of "The Trade Union Act, 1871 . . . . The object of the Act is to give relief to trade unions in certain clearly defined directions, to enable them to sue certain actions and enforce certain rights which they could not sue and enforce before." And again, in Aitken v. Associated Carpenters and Joiners of Scotland ${ }^{3}$ the same eminent authority said: "The spirit and object of the Statute of 1871 is, I think, to take the laws of trade unions and their administration out of the cognizance of the ordinary tribunals, - in other words, to deprive members of trades unions of the benefit of applying

1 M'Kernan v. United Operative Masons' Association, (1874) 1 R. 453.

(a) $\Lambda \mathrm{s}$ to the present law relating to the jurisdiction of
2 (1877) 4 R. 823.

3 (1885) 12 R. 1206.

the Courts in inter-union matters, vide Chapter V. 
to the ordinary tribunals of the country to enforce the provisions of their associations."

$$
\text { After the Trade Union Act, } 1871 .
$$

On this minority report (a) the Trade Union Act of 1871 was founded, and it remains the principal Act defining the legal position, status, powers and liabilities of trade unions. Its general effect has been stated by Lord Justice Farwell as follows :- "Prior to the passing of the Act of 1871 a trade union, as such, had no legal status. It was, speaking generally, an association of wage-earners for the purpose of improving or maintaining the conditions of employment. It combined the objects of a friendly society with those of a trade guild. In the former capacity it gave relief to its members when out of work from sickness or accident or on strike, that is 'dispute' and 'unemployed' benefits; and in the latter capacity it bargained with employers on behalf of all its members, and, with the influence of a united body, for higher wages, shorter hours, and the like. There was also the further question, in which the masters were only indirectly interested, of encroachment of trade on trade. These and such as these were the proper functions of a trade union in 1871." 1

No. distinction was made in the 1871 Act between the benevolent and trade purposes of a trade union. In Amalgamated Society of Railway Servants v. Osborne (No. 1), ${ }^{2}$ Lord Macnaghten ${ }^{1}[1909] 1$ Ch. 163 , at p. $188 .{ }^{2}$ [1910] A. C. 87 , at p. 95 .

(a) Supra, p. 13. 
said: "Whatever may have been the origin of trade unions, it is a matter of common knowledge that many such societies were in existence long before the Act of 1871. Generally speaking, they had two main objects. They were combinations for trade purposes, and for benevolent purposes as well. But when the struggle began which led to the Act of 1871, those who managed the case on the part of trade unions insisted that the benevolent purposes of a union were to be regarded as secondary and subordinate to its trade purposes. They urged that the strength of the union and the confidence of its members simply consisted in this, that it could, if so disposed, employ the whole of its funds in support of trade ends. They objected to any separation of funds as being calculated to paralyse the efficacy of the institution and tantamount to a proposal to suppress unionism by statute. Hence it comes that the benevolent purposes of trade unions, though referred to in the Trade Union Acts, 1871 and 1876, are not mentioned either in the original or in the amended definition of the term 'trade union.' They are relegated to an inferior and subordinate position."

Registration.

By the 1871 Act, trade unions were given permission to register themselves and thereby acquire certain further rights. In the words of Lord Justice Farwell in Osborne v. Amalgamated Society of Railway Servants (No. 1)," "The Act makes provision for the registration of trade unions 
with resulting advantages not given to unregistered societies. The Act is framed on the lines of the Companies Act, 1862, and provides that any seven or more members of a trade union may, by subscribing their names to the rules of the union, register the union with a name and the exclusive right thereto. Such union can buy and sell land not exceeding one acre, and personal estate, without limit of amount, for the use and benefit of such trade union and the members thereof. Trustees have power to bring and defend actions touching such property. Treasurers and officers are bound to account, and annual returns have to be made to the registry of the assets and liabilities, receipts and expenditure of the union, and the union must have rules in the scheduled form, by which, amongst other things, it is required to state the whole of its objects, and provision is made for its amalgamation with other unions and its winding up. A registered trade union is thus a statutory legal entity, anomalous in that, although consisting of a fluctuating body of individuals, and not being incorporated, it can own property and act by agents" $(a)$.

Speaking generally on the effect of the Act Status of of 1871 on the legal position of trade unions, trade Farwell, L.J., observed in the Taff Vale case: "A trade union is neither a corporation nor an individual, nor a partnership between individuals. It is an association of men which almost invariably owes

(a) As to the present law relating to registration, vide Chapter II. 
its legal validity to the Trade Union Acts, 1871-76 ..."; and "the Legislature, in giving a trade union the capacity to own property and the capacity to act by agents, has, without incorporating it, given it two of the essential qualities of a corporation." 1

This anomalous position was purposely created by Parliament; both the Government and the trade unions desired to create a body which could neither sue nor be sued in Courts of law $(a)$. "It has been said," wrote George Howell, one of the persons responsible for the 1871 Act, "that some of the unions desired incorporation, but that I deny. It was intentionally omitted from the bill." According to the "History of Trade Unionism" (b), "some of the officials were, in 1871, demanding the complete legalisation of the unions in the same manner as friendly societies. They had failed to realise that such legalisation would have exposed them to be sued by one of their members who might be excluded for working contrary to the interests of the trade. The whole efficacy, from the trade union point of view, of the amalgamation of trade and friendly benefits would have been destroyed." "At present, the strength of the union and the confidence of its members consist in this, that it can, if so disposed, employ the whole of its funds in the support of trade ends-an enforced separation of the funds of the

${ }^{1}$ [1901] 1 K. B. 170; approved [1901] A. C. 426.

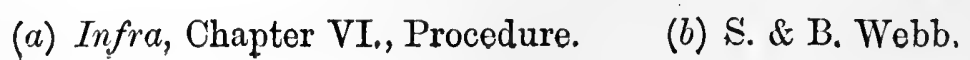


union would be an arbitrary interference with the liberty of association . . . and would be tantamount to the suppression of trade unionism by statute" (a). "Trade unions remain voluntary associations of which the law can take no special cognizance as collective bodies, and it is provided by the fifth section of the 1871 Act that the Acts relating to friendly societies and industrial and provident societies, and the Companies Acts, shall have no application to trade unions, the object apparently being to make careful provision that they should not have any corporate existence or capacity whatever." 1

Nevertheless, despite these opinions and decisions, of late years the judges have tended to hold that even under the statute of 1871 sufficient elements of corporate existence are present, at any rate in the case of a registered trade union, ${ }^{2}$ to make a union liable to be sued or capable of suing in its trade name. "If the Legislature has created a thing which can own property, which can employ servants and which can inflict injury, it must be taken to have impliedly given the power to make it liable in a court of law."3 In the case, moreover, of Amalgamated Society of Railway Servants v. Osborne (No. 1), ${ }^{4}$ it was held that, though the Act of 1871 does not make a trade

1 Per Lord President Inglis, in Aitken v. Associated Carpenters, (1885) 12 R. 1206.

2 Vide Lord Skerrington, in Wilson v. Scottish Typographical Association, (1911) 1 S. L. T. 253.
3 Per Lord Halsbury, in Taff Vale Railway Company v. Amalgamated Society of Railway Servants, [1901] A. C. at p. 436 . 4 [1910] A. C. 87 .

(a) Royal Commission, 1869, Minority Report. 
union a corporation, yet the rule that "wherever a corporation is created by Act of Parliament, with reference to the purposes of the Act, and solely to carry those purposes into execution, the powers which the corporation may use in furtherance of those objects, must be expressly conferred by or derived by reasonable implication from its provisions," and was held by analogy to apply equally to trade unions $(a)$.

Thus, although trade unions are not in fact incorporated, they must be deemed to be statutory corporate bodies, at any rate when registered; and, as the definition of a trade union in the Trade Union Acts contains the purposes for which they are incorporated, the purposes which they may lawfully execute at any time will be limited strictly by the ambit of such definition, modified by such express enabling powers as Parliament may from time to time confer upon them.

(a) As to the present law relating to status, etc., vide Chapter VI. 


\section{CHAPTER II.}

\section{DEFINITION OF TRADE UNIONS AND THEIR \\ POWERS.}

\section{Trade Unions Defined.}

A tRADE union has been defined by statute as any statutory combination, whether temporary or permanent $(a), \quad \begin{aligned} & \text { Defin } \\ & \text { tion. }\end{aligned}$

(a) for regulating the relations between workmen and masters; or

(b) for regulating the relations between workmen and workmen; or

(c) for regulating the relations between masters and masters ; or

(d) for imposing restrictive conditions on the conduct of any trade or business $(b)$.

But a combination concerning solely,

(a) Any agreement between partners as to their own business ; or

(b) Any agreement between an employer and those employed by him as to such employment; or

(c) Any agreement in consideration of the sale

(a) Whether such combination would or would not, if the Trade Union Act, 1871, had not been passed, have been deemed. to be an unlawful combination by reason of some one or more of its purposes being in restraint of trade, $(1876) 39 \& 40$ Vict. c. 22 , s. 16 .

(b) $(1876) 39 \& 40$ Vict. c. 22 , s. 16 . 
Common

Law Definition.
Scope of Statutory Definition.

of the goodwill of a business or of instruction in any profession, trade or handicraft, is not thereby constituted a trade union $(a)$. A combination that has among its objects the regulation of such matters as are referred to in the statutory definition is not necessarily a trade union. "The legislature did not create the name for the purpose of the Trade Union Acts. It was at the time a well-known term, connoting combinations of a known type formed for objects and purposes which were well recognised." " In Hornby v. Close, ${ }^{2}$ decided prior to the passing of the 1871 Act, Cockburn, C.J., said that the term trade union may be held to include "every combination by which men bind themselves not to work except under certain conditions, and to support one another, in the event of being thrown out of employment, in carrying out the views of the majority," and a similar definition, extended to cover the case of combinations of masters as well as of men, was embodied in the Trade Union Act, 1871, as above cited.

This definition, though applying to combinations for regulating the relations between workmen and masters, or between members of either class, did not expressly apply to the regulation of industry. "Before the passing of the 1876 Act there might possibly have been some doubt as to whether a society imposing conditions with regard to the

1 Per Fletcher Moulton, I.J., (No. 1), [1909] 1 Ch. 163, at in Osborne v. Amalgamated p. 184. Society of Railway Servants ${ }^{2}$ (1867) 2 Q. B. 153.

(a) (1s71) $34 \& 35$ Vict. c. 31 , s. 23. 
transaction of business was a trade union, and this doubt led to the passing of section 16 of the Act of 1876, which further defines a trade union as being a combination for imposing restrictive conditions on any trade or business." 1

The terms of the statutory definition are very wide, so that, in order to show that a combination is not a trade union, it is insufficient to show that the regulations imposing restrictive conditions on any trade are only such as are necessary to secure results beneficial to such trade. ${ }^{2}$ Thus, a trading association, which fixes the rate at which trading companies, federated to the association, may charge for their goods, ${ }^{3}$ and a trade protection society, which imposes restrictions on the federated trading companies as to the employment by them of particular persons, are trade unions $(a)$.

A trade union cannot be registered as a limited Trade company under the Companies (Consolidation) Act, Union 1908, and, if so registered, the registration is void $(b)$. Where the Court is of opinion that

1 Per Lord Alverstone, M.R., Water Manufacturers Defence in Chamberlain's Wharf, Ltd. v. Smith, [1900] 2 Ch. 605, at p. 612.

${ }^{2} \mathrm{Per}$ Lord Moncreiff, in Edinburgh and District Aerated

(a) Mineral Water Bottle Exchange and Trade Protection Society v. Booth, (1887) 36 Ch. D. 465. Where an incorporated society, whose charter expressly prohibits it being a trade union, takes over the business of a trade union, the imposition by the society of restrictive con-
Association, Ltd. v. Jenkinson (1903), 5 F. 11 09 , at p. 1163.

3 Chamberlain's Wharf, Ltd. v. Smith, [1900] 2 Ch. 605.

ditions is ultra vires. Aberdeen Master Masons' Incorporation, Ltd. v. Smith, (1908) 10 F. 669.

(b) (1871) 34 \& 35 Vict. c. 31, s. 5(3). Such an association may apparently be an unregistered company, and be wound up as such. (1908) 8 Edw. VII., c. 49.
Statutory Registered Limited Company, or Provident or Friendly Society. 
a society, whose objects are partly those of a friendly society, comes within the definition of trade union $(a)$, the society cannot avail itself of the Industrial and Provident Societies Acts, nor of the Friendly Societies Acts, and its registration under the Friendly Societies Acts is void (b).

How far a Statutory Insurance Company.

A registered trade union is not a statutory insurance company, and is exempt from the provisions of the Assurance Companies Act, 1909 (c). An unregistered trade union carrying on insurance business, and originally established more than twenty years before the commencement of the 1909 Act, may, on application, receive from the Board of Trade the exemption conferred by that Act on registered trade unions, if it appears to the Board, after consulting the Chief Registrar of Friendly Societies, that the society is one to which it is inexpedient th at theprovisions of this Act should apply. It would appear, therefore, that an unregistered trade union, established within twenty years of the $3 \mathrm{rd}$ of December, 1909, must comply with the requirements of the Assurance Companies Act, $1909(d)$.

No trade union, registered or unregistered, may insure against or pay, on the death of a child under ten or five years of age, any sum of money which, added to any amount payable on the death of such child by any other society, exceeds ten or six

(a) Per Lindley, J., in Swaine theless, be a trade union.

v. Wilson, (1889) 14 Ch. D. 252, at p. 259 ; Old v. Robson, 59 L. J. M. C. 41. A provident society, notwithstanding that its "fundamental object" is the relief of members, may, never-

(b) (1871) 34 \& 35 Vict. c. 31 , s. $5(1),(2)$.

(c) (1909) 9 Edw. VII., c. 49, s. 1.

(d) Ibid., s. 35 . 
pounds respectively $(a)$. No such trade union may pay any sum on the death of a child under ten years of age except to the parent of the child, or to the personal representative of the parents, upon production by either of these of a certificate of death issued by the registrar of deaths, or other person having the care of the register of deaths. The certificate of death must be indorsed with certain particulars as to the liability of the trade union $(b)$. Any trade union, or office or member thereof, who pays money on the death of a child under ten years, otherwise than in the manner provided by the Friendly Societies Act, 1896, is liable to a penalty not exceeding five pounds $(c)$.

\section{Powers of Trade Unions Defined.}

The definition of a trade union contained in the Acts of 1871 and 1876 is a limiting and restrictive definition. ${ }^{1}$ The Trade Union Acts constitute, as it were, a charter of incorporation; they render some things lawful which would otherwise be unlawful, and what is not within the ambit of the statute is prohibited to a trade union. ${ }^{2}$

It is a broad and general principle that companies, incorporated by statute for special purposes, and

1 Per Cozens-Hardy, M.R., in Osborne v. Amalgamated Society of Railway Servants (No. 1),
[1909] 1 Ch. 163, at p. 175.

2 Per Earl of Halsbury, ibid., [1910] A. C. 87, at p. 93 . 'a) (1876) $39 \& 40$ Vict. c. 22 , s. 2 ; (1896) 59 \& 60 Vict. c. 25 , s. 62 .

(b) Ibid., ss. 63, 64. Several other formalities must be com-
Powers of Trade

Unions restricted within Statutory Definition. plied with, as to which see the Friendly Societies Act, (1896) 59 $\& 60$ Vict. c. 25 , ss. $62-67$.

(c) 1bid., ss. 84 (1), 89 . 
societies, whether incorporated or not, owing their constitution and their status to Act of Parliament and having their objects and powers defined thereby, cannot apply their funds to any purpose foreign to the purposes for which they were established, or embark on any undertaking in which they were not intended by Parliament to be con"Uires" cerned. ${ }^{1}$ Whenever a corporation is created by Doctrine. Act of Parliament with reference to the purposes of the Act, and solely with a view to carrying those purposes into execution, not only the objects which the corporation may legitimately pursue must be ascertained from the Act itself, but the powers which the corporation may lawfully use in furtherance of these objects must either be expressly conferred or derived by reasonable implication from its provisions ${ }^{2}$ and this principle is not confined to corporations created by special Acts of Parliament. It applies with equal force in every case where a society or association, formed for purposes recognised and defined by an Act of Parliament, places itself under the Act, and by so doing obtains some statutory immunity or privilege. This law applies to all companies created by any statute for a particular purpose. ${ }^{3}$

A definition which permitted trade unions to do the particular things named in the statute, and in addition all things not in themselves illegal, would be no definition at all. The question is whether the

1 Per Lord Macnaghten, in Amalyamated Society of Railway Servants v. Osborne (No. 1), [1910] A. C. 87, at p. 94 .

2 Per Lord Watson, in Wenlock v. River Dee Co., (1885) 10 App. Cas. 362.

${ }^{3}$ Per Lord Blackburn, in Aslibury Railway Co. v. Riche, (1874) 7 II. I. 653. 
Legislature has conferred upon registered trade unions, expressly or by fair implication, a specific power, and the test as to whether a trade union has or has not any specific power is to be proved in the answer to the question: "Does the power merely provide a method of conducting business, or is it a power making the society a thing different from that which is specified in the Act and meant by the Act?"1

Thus, among the powers, which have been held to Extent of be ultra vires a registered trade union, is the right to collect and administer funds for political purposes $(a)$ Trade Union either to return and pay members of Parliament ${ }^{2}$ or Powers. for the purpose of municipal representation. ${ }^{3}$. It is probably ultra vires a trade union to carry on a trade or a newspaper. ${ }^{4}$ The dictum of Mathew, J., in Linaker v. Pilcher ${ }^{5}$ that a trade union could carry on a newspaper cannot now be regarded as correct, but while a trade union cannot lawfully publish a newspaper in the ordinary sense of the word, it is probably within its rights in issuing a sheet sent to the members containing reports of their proceedings and the like. ${ }^{6}$ On the other hand, though the definition of trade union contains no express

1 Per Lord Atkinson, in Amalyamated Society of Railway Servants v. Osborne(No. 1), [1910] A. C. 87 , at pp. 99 et seq.

2 Ibid., pp. 87 et seq.

3 Wilson v. Amalgamated Society of Engineers and Others, [1911] 2 Ch. 324.

4 Per Farwell, I.J., in Osborne v. Amalgamated Society of Railway Servants (No. 1), [1909] 1 Ch. 163 , at p. 192 .

5 (1901) 84 I. T. 421.

- Per Farwell, I.J., in Osborne v. Amalyamated Society of Railway Servants (No. 1), [1909] 1 Ch. 163, at p. 192.

(a) For a list of injunctions granted against trade unions restraining them from such acts, see Appendix VI. 
reference to providing benefits for members, the provision of benefits is probably covered in the definition by the words "regulating the relations between workmen and workmen," and is certainly a purpose collateral or ancillary to the purposes which are set forth in the definition $(a)$.

Powers of unregistered Trade Unions.

While, however, it is now law that a registered trade union is restricted in its functions to such powers as are expressly conferred by, or derived by reasonable implication from, the defining sections of the Trade Union Acts, the position of an unregistered trade union in this respect is not so clear. In the Osborne Case (No. 1) Lord Macnaghten., ${ }^{1}$ Cozens-Hardy, M.R., ${ }^{2}$ and Farwell, L.J., ${ }^{3}$ apparently limited the application of the doctrine that a trade union was a quasi-corporation, whose powers were expressly conferred by statute, to a registered trade union. Lord Halsbury, on the other hand, in the same case, appears to have applied this doctrine to all trade unions, whether registered or unregistered. ${ }^{4}$ In Wilson v. Scottish Typographical Association, ${ }^{5}$ decided subsequently to the Osborne Case, Lord Skerrington said: "It is apparent that the ground of judgment, that purposes of a society are matters outside the purview of the Trade Union Acts and therefore ultra vires of the society, can

${ }^{1}$ [1910] A. C. 87, at p. 94 .

2 [1909] 1 Ch. 163, at p. 176.

3 I bid., at p. 190.

(a) Per Isord Atkinson, in Amalyamated Society of Railmay Servants v. Osborne (No. 1), [1910] A. C. 87 , at p. 102 . Apart from
4 [1910] A. O. 87, at p. 93.

${ }^{5}(1911) 1$ S. L. T. 253.

the definition, the 1871 Act itself says that a trade union may provide benefits. 
have no application to a society, which has no statutory constitution, and which is merely a voluntary association, such as an unregistered trade union " $(a)$.

A trade union may become an approved society under the National Insurance Act, 1911 (b).

National Insurance.

\section{Registered Trade Unions.}

The Trade Union Act, 1871, makes the registration of a trade union optional, but a trade union is not illegal on the ground that it is unregistered. Powers acquired by regisSpecial advantages, however, are afforded to such trade unions as register themselves. Thus, such trade unions may purchase or take upon lease land not exceeding one acre $(c)$. The property of the trade union becomes vested in trustees $(d)$, and actions may be brought by or against the trustees with regard to such property $(e)$. 'The treasurer is compelled to account on demand to the trustees or members for moneys passing through his hands $(f)$, and penalties may be exacted by such registered union against members who have misapplied the property of the union or their representatives $(g)$.

(a) It may be worth observing that Leigh Clare, V.-C., in following the decision in the Osborne Case (No. 1), six months previously to Lord Skerrington's judgment, said that the fact that one trade union is registered and another unregistered is immaterial. Chancery Division, Manchester Assize Courts, July 8th, 1910, infra, p. 169. Wolfe v. Mathews, (1882) 21
Ch. D. 194.

(b) $1 \& 2$ Geo. V., c. 55. For conditions, etc., under which a trade union can become such an approved society, see Appen$\operatorname{dix} \mathrm{V}$.

(c) (1871) $34 \& 35$ Vict. c. 31 , s. 7.

(d) Ibid., s. 8.

(e) Ibid., s. 9 .

(f) Ibid., s.

(g). Ibid., s. 12 


\section{Registration.}

Applica- Any seven or more members of a trade union tion to register. may register their trade union by subscribing their names to the rules of the union $(a)$ and otherwise complying with the provisions of the Trade Union Acts $(b)$ and the regulations made under those Acts with respect to registration $(c)$. Unless the rules provide to the contrary, any person over the age of sixteen may be a member of a trade union, and is therefore competent to subscribe $(d)$. But if the registrar has reason to believe that the applicants have not been duly authorised by the trade union to make the application, he may require evidence from them to that effect $(e)$.

Regulations of Secretary of State.

As regards the regulations respecting registration it is provided that one of the principal Secretaries of State (in Scotland the Secretary for Scotland) shall have power to make regulations respecting registration and respecting the seal (if any) and the forms to be used for the purpose of registration. He may make regulations respecting the inspection of documents kept by the registrar and the fees (if any) to be paid on registration, but such fees must not exceed the sum of $£ 1$ for registration and $2 s .6 d$. for inspection of documents $(f)$. The fee of $£ 1$

(a) (1871) $34 \& 35$ Vict. c. 31 , s. 6 .

(b) The Trade Union Acts, 1871 and 1876, and the Trade Disputes Act, 1906, are cited together as the Trade Union Acts, 1871 to 1906 (6 Edw. VII., c. 44$)$, s. 5 (1).

(c) Vide Appendix II., p. 224. (d) (18;6) $39 \& 40$ Vict. c. 22 , s. 9 ; but vide infra, p. 44.

(e) Regulation made by Secretary of State as to registration of trade unions (Reg. (3)), Appendix II., p. 224.

(f) (1871) $34 \& 35$ Vict. c. 31, s. $13(6)$; Second Schedule. 
is in fact the fee fixed by the Secretary of State for the certificate of registration of a trade union $(a)$.

Certain of the requirements, therefore, imposed upon unions desiring registration are contained in the Trade Union Acts, and certain of them have been made by the Home Secretary duly acting under the Acts. On the general power of the Home Secretary to make regulations, Blackburn, J., in $R$. v. Registrar of Friendly Societies, ${ }^{1}$ observed: "I cannot see why the regulations are not within the Power of Seeretary of State to make regulaauthority given to the Secretary of State by s. 13 (6) of the 1871 Act." The learned judge's opinion would seem to indicate that the words "the Secretary of State may from time to time make regulations respecting registry under this Act" (b) confer a general power on him.

On the other hand, while the Secretary of State may make general regulations, the fact that he or his deputy is satisfied that his requirements have been carried out will not necessarily validate the proceedings of the union in seeking registration. In Osborne v. Amalgamated Society of Railway Servants (No. 1), Lord Justice Fletcher Moulton said: " "It is true that by the provisions of section 13 (6) of the Act of 1871, under regulations made by the Home Secretary, power is given to any seven members of the union to apply for the registration of alterations of rules. But there is not in the sub-section authorising the making of these (altered) rules anything which would

1 (1872) 7 Q. B. 741.

${ }^{2}$ [1909] 1 Ch. 163, at p. 180.

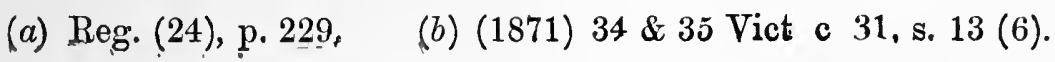


entitle the Home Secretary to interfere with the provisions of the Act or the rules of a trade union with regard to the proceedings necessary to give validity to an alteration."

It would seem safe to infer that this dictum could also be applied to the original proceedings taken at the time of registration $(a)$. The certificate of the registrar affirming due compliance with the regulations made by the Secretary of State is not necessarily conclusive as to the validity of such proceedings.

Powers of registrar to refuse to register.
With regard to the requirements as to registration, it is provided that, if any of the purposes of the trade union, which it is sought to register, are unlawful, the registration is void $(b)$, and the registrar, on his being satisfied that any of the purposes of the trade union have become unlawful, must cancel the certificate of registration, no notice to the trade union to that effect being required. Moreover, on proof to the satisfaction of the registrar, either

(a) That the certificate was obtained by fraud or mistake; or

(b) That the trade union has, after notice from the registrar, wilfully violated any of the provisions of the Trade Union Acts ;

the registrar may cancel the certificate, but in these specified cases, before the certificate is actually cancelled (which cancellation must be on a form prescribed $(c)$ ), not less than two months' notice in writing (on a prescribed form $(d)$ ), specifying the
(a) Infra, p. 39.
(c) For form, vide infra, p. 238.
(b) (1871) $34 \& 35$ Vict. c. 31 ,
(d) For form, vide infra, p. 237. s. 6 . 
grounds of the proposed withdrawal or cancellation, must be given by the registrar to the trade union (a). A trade union, whose certificate of registration has been withdrawn or cancelled, ceases absolutely, from the time of such withdrawal or cancellation, to enjoy, as such, the privileges of a registered trade union, but it is nevertheless exposed to any liability which may be enforced against it as if such withdrawal or cancellation had not taken place $(b)$.

The registrars of trade unions, to whom applica- Appointtion to register is made, are the registrars of friendly societies $(c)$. By the Friendly Societies Act, 1896, tion of for the purpose of registering friendly societies, a chief registrar and one or more assistant registrars of friendly societies for England, and assistant registrars for Scotland and Ireland, are appointed by and hold office during the pleasure of the Treasury. Every chief registrar must be a barrister of not less than twelve years' standing. One, at least, of the assistant registrars for England and every assistant registrar for Ireland must be a barrister or solicitor of, respectively, not less than seven years' standing. Every assistant registrar for Scotland must be an advocate, writer to the signet, or solicitor, of not less than seven years' standing in their respective professions $(d)$. The assistant registrars are subordinate to the chief registrar $(e)$.

(a) (1876) $39 \& 40$ Vict. c. 22 , s. 6.

s. 8 ; Regs. (13) \& (14), p. 226.

(b) Ibid., s. 28.

(d) (1896) $59 \& 60$ Vict. c. 25 ,

(c) (1871) $34 \& 35$ Vict. c. 31 ,

s. 1 ; Reg. (1), p. 224.

T.U.

(e) Ibid., s. $\mathbf{3}$.

ment and qualitica- 
The

Central Office.

Formalities of registration.

The Central Office of the chief registrar is the Central Office of the Registrar of Friendly Societies, and exercises the functions of the registrar for England $(a)$. The assistant registrars for Scotland and Ireland are required to send to the central office in London copies of all documents, registered or recorded by them, as the chief registrar may from time to time direct $(b)$.

The application to register a trade union must be sent to the registrar (on a prescribed form $(c)$ ), together with printed copies of the rules and a list of the titles and names of the officers $(d)$, and upon being satisfied that the trade union has complied with the regulations in force, it is his duty to register the trade union and its rules $(e)$.

Registered No trade union may be registered under a name name. identical with that by which any other existing trade union (whether registered or unregistered) is known, or so nearly resembling such name as to be likely to deceive members or the public $(f)$. When a trade union is already in operation, the registrar, upon an application for its registration, may, if he has reason to believe that the applicants have not been duly authorised by the union to make the application, require evidence from them of the facts $(g)$. The evidence accompanying the application must be made on a special form $(h)$.

(a) (1896) $59 \& 60$ Vict. c. $25, \quad$ ss. 6,13 (1) \& (2).

s. 8 (1).

(b) Ibid., s. 4.

(c) For form, vide infra, p. 231.

(d) Infra, pp. 44 et seq.

(e) (1871) 34 \& 35 Vict. c. 31 , (f) Ibid. s. $13(3)$; Reg. (2), p. 224.

(g) Reg. (3), p. 224.

(h) Ibid.; for form, vide infra, p. 232. 


\section{TRADE UNIONS AND THEIR POWERS.}

'The registrar's duties are ministerial and not Registrar's judicial. In $R$. v. The Registrar of Friendly Societies, ${ }^{1}$ each of two sections of a trade union functions ministerial, not judicial. applied to register by the name which the original society had always borne. The registrar heard evidence from each side, and, finding that there was a bona fide dispute, refused to register the trade union at all until the decision of the Court should determine the legal position of the parties. The registrar's refusal was approved. Blackburn, J., said :" "The effect of registering either section of the society by the name claimed by both would be virtually to give that section the control of the funds of the society. I think the registrar, as soon as he found each body of persons claiming as against one another a large sum of money, was bound to say, 'I won't alter the position of the parties, or do anything by registering one set of applicants which may prejudice the others." "

Every registered trade union must have a registered office, for the reception of communications and Registered office.

notices. If any trade union is in operation for seven days without having such an office, such trade union and every officer thereof incurs a penalty not exceeding $£ 5$ for every day during which the union is in operation. Notice of the situation of the office and of any change thereof must be given (on a prescribed form $(a)$ ) to the registrar and must be recorded by him; and, until such notice is given, the trade union has not complied with the
${ }^{1}$ (1872) 7 Q. B. 741.
2 Ibid., at p. 744.

(a) For form, vide infra, p. 234. 
conditions of registration (a). The removal of the registered office of a trade union from one country (i.e., England and Wales, or Scotland or Ireland) to another does not render re-registration of the union necessary $(b)$.

Domicile for regis. tration.

Trade unions carrying on or intending to carry on business in more than one such country must be registered in the country in which their registered office is situate. All matters requiring registration must be registered with, and returns and notices must be sent to, the registrar of the country in which the trade union is situate. Copies of such returns and notices are sufficient, when required, for other countries $(c)$.

Registered In addition to having an office, a trade union rules. desiring registration must have and register rules $(d)$. In the case of unions carrying on or intending to carry on business in more than one country, copies of the rules, and of all amendments of the same, must, when registered, be sent to the registrar of each of the other countries in which the trade union carries on or intends to carry on business, to be recorded by him. Until such rules are so recorded, the union will not be entitled, in the country in which such rules have not been recorded, to any of the privileges arising from registration, and, until such amendments of rules be recorded, the same cannot take effect in that country $(e)$. A trade union having its registered office in one
(a) (1871) 34 \& 35 Vict. c. 31 ,
(d) For specimen rules see

s. 15.; Reg. (15), p. 226.

(b) Reg. (15 A), p. 227.

(c) Reg. (15 B.), p. 227. Appendix IV., p. 245.

(e) (1876) 39 \& 40 Vict. c. 22 , s. 6 . 
country, but which has recorded its rules with another in accordance with this requirement, is subject to the jurisdiction of the Courts in the country in which its rules have been recorded. ${ }^{1}$ The rules must contain the following particulars $(a)$ :

1. The name of the trade union $(b)$ and its place of meeting for the transaction of its business.

2. The whole of the objects, for which the trade Particulars to be contained in rules. union is to be established; the purposes for which the funds thereof shall be applicable; the conditions under which any member may become entitled to any benefit assured thereby; and the fines and forfeitures which it resolves to impose on any of its members. The objects must be objects which it is competent for a trade union to pursue, ${ }^{2}$ but the Court will not prevent a trade union carrying out one of its lawful objects, provided for in its rules, merely on the ground that the rules do not contain the machinery necessary for carrying out such object. ${ }^{3}$ It will not interfere in mere matters of internal administration. ${ }^{4}$

3. The manner of making, altering, amending and rescinding rules. Where the rules contain a

1 Mackendrick v. National Union of Dock Labourers in Great Britain and Ireland, (1911) 48 S. L. R. 17.

2 Amalgamuted Society of Railway Servants v. Osborne (No. 1), [1910] A. C. 87.

(a) Where rules form an exhaustive code, it is ultra vires the governing body to vary them. In re Durham Miners' Association, Watson v. Carr, (1900) 17 T. L. R. 39.
${ }^{3}$ Per A. T. Lawrence, J., in Burke v. Amalgamated Society of Dyers, [1906] 2 K. B. 583, at p. 591.

4 Steele v. South Wales' Miners' Federation, [1907] 1 K. B., at pp. 366, 368 .

(b) In which registered name a trade union may sue or be sued. Taff Vale Ruilway v. Amalgamated Society of Railuay Servants, [1901] A. C. 426, infra, pp. 174 et seq. 
provision for alteration, effectual when carried by a stipulated majority, every member is bound by alterations thus duly carried. ${ }^{1}$

4. A provision for the appointment and removal of a general committee of management, of a trustee or trustees, treasurer, and other officers.

5. A provision for the investment of the funds, and for an annual or periodical audit of accounts $(a)$.

6. A provision for the inspection of the books and names of members of the trade union by every person having an interest in the funds of the trade union (b). The members of the trade union are entitled to employ an accountant to inspect the books and accounts for them, provided that the accountant gives an undertaking that the information obtained will only be used for informing his clients of the result of the inspection. ${ }^{2}$

7. A provision for dissolution $(c)$. In the absence of rules dealing with the distribution of funds on dissolution, where the members of a trade union, about to be dissolved, are subscribing in different proportions and receiving proportionate benefits, then the money is divisible among them, in proportion to the amounts respectively contributed. ${ }^{3}$

1 This even if such member is non compos: Burlie v. Amalgamated Society of Dyers, [1906] 2 K. B. 533, at p. 588. Steele v. South Hales Miners' Federation, [1907] 1 K. B. 361 .

(a) Infra, p. 46.

(b) (1871) 34 \& 35 Vict. c. 31 , s. 14 (1); First Schedule.

(c) A trade union registered before the 30th June, 1876, does
2 Norrey v. Keep, [1909] $1 \mathrm{Ch}$. 561.

3 In re Printers and Transferers' Amalyamated Trades Protertion Society, [1899] 2 Ch. 184.

not have its rules invalidated by the absence of such a provision, (1876) $39 \& 40$ Vict. c. 22 , s. 14 . 
In case of doubt as to the meaning of the rules, application may be made to the Court to determine their construction. ${ }^{1}$

A copy of their rules must be delivered by a copies of trade union to every person on demand, on payment of a sum not exceeding one shilling $(a)$, and it is a misdemeanour for any person, with intent to mislead or defraud, to give to any person who intends to become or is a member of a trade union a copy of the rules, incorrect in whole or in part, whether by addition, alteration or omission, or to give to any such person a copy of the rules of an unregistered trade union on the pretence that such trade union is in fact registered $(b)$.

Upon registering the trade union, the registrar must issue a certificate of registration (in a prescribed of registraform $(c)$ ), which is conclusive evidence that the requirements to obtain registration have been complied with, unless the certificate be proved to have been withdrawn or cancelled $(d)$. But the certificate of the registrar is not conclusive evidence as to whether the society is or is not lawful, ${ }^{2}$ nor as to the validity of the proceedings taken by a trade union for the passing of such rules and regulations. ${ }^{3}$ In the case of a trade union which has been in operation for more than a year before the date of the

1 In re Durham Miners' Asso- 901. ciation, Watson v. Cann, (1900) 17 T. L. R. 39.

3 Osborne v. Amalgamated ${ }^{2}$ Gozney v. Bristol Trade and (No. 1), [1909] 1 Ch. D. 163 ; Provident Society, [1909] 1 K. B. affirmed [1910] A. C. 87.

(a) (1871) $34 \& 35$ Vict. c. $31, \quad$ (c) For form, vide infra, p.232. s. $14(2)$.

(d) (1871) $34 \& 35$ Vict. c. 31 ,

(b) Ibid., s. 18.

s. $13(5)$. 
application for registration, there is a special provision, whereby a general statement of the receipts, funds, effects and expenditure of the trade union must be delivered to the registrar. Such statement must be in a similar form to the annual general statement of a trade union $(a)$.

Change of name.

A trade union may change its name, with the consent of not less than two-thirds of all its members, provided that the approval in writing (in a prescribed form) of the chief registrar (and in the case of trade unions registered and doing business exclusively in Scotland or Ireland, of the assistant registrar for Scotland or Ireland respectively) be first obtained $(b)$. Notice in writing of every such change in name, signed by seven members, and countersigned by the secretary of the trade union, accompanied by a statutory declaration by him (in a prescribed form), that the foregoing requirements in respect of change of name have been complied with, must be sent to the central office of the chief registrar and registered there, and until such change of name is so registered the same does not take effect $(c)$. Such change of name does not, by itself, affect the rights or obligations of a registered trade union or of its members $(d)$.

Amalgamation.

Any two or more trade unions may, with the consent of not less than two-thirds of all the members of every such trade union, amalgamate as one trade union, with or without any dissolution or

(a) (1871) 34 \& 35 Vict. c. 31, infra, p. 239.
s. 13 (4).
(c) Ibid., s. 13 ; Reg. (16);
(b) (1876) $39 \& 40$ Vict. c. 22 , for form, vide infra, p. 240.

s. 11 ; Reg. (16); for form, vide

(d) Ibid., s. 11 . 
division of the funds of such trade unions $(a)$. It would appear that, in spite of this general power, the rules must specifically authorise the amalgamation. ${ }^{1}$ Notice in writing of every such amalgamation, signed by seven members, and countersigned by the secretary of every amalgamating union (in a prescribed form), accompanied by a statutory declaration (in a prescribed form), made by every such secretary to the effect that the foregoing requirements in respect of amalgamation have been complied with, must be sent to the central office of the chief registrar and be registered there; and, until such amalgamation is so registered, the amalgamation does not take effect $(b)$. Such an amalgamation does not prejudice the right of a creditor of an amalgamating trade union $(c)$.

At the request of a trade union, the certificate of registration may be withdrawn by the chief registrar (in the case of trade unions registered and Withdrawal of certificate of registracarrying on business exclusively in Scotland or Ireland, by the assistant registrar of Scotland or Ireland respectively). This request must be sent (in a prescribed form) to the registrar, and the withdrawal of the certificate by the registrar is in a prescribed form $(d)$.

Every registered trade union must transmit to Annual the registrar annually, before the 1st of June, a of Trade

1 Per Fry, J., in Wolfe v. Mathews, (1882) 30 W. R. 838, at p. 839. Union.

(a) (1876) $39 \& 40$ Vict. c. 22 , s. 12 ; Reg. (22).

(b) Ibid., s. 13 ; Reg. (22). For forms, vide infra, pp.243, 244. (c) Ibid., s. 12.

(d) Ibid:, s. 8; Regs. (12), (14); for forms, vide infra, pp. $237,238$. 
general statement of its receipts, funds, effects, and expenditure, showing the assets and liabilities at that date and the receipts and expenditure with the respective items thereof during the year preceding. The statement must be prepared and made out up to. such date, in such form, and with such particulars as the registrar may require. Every member of and depositor in any such trade union is entitled, on application to the treasurer or secretary of the trade union, to receive a copy of the general statement, free of charge. Together with the general statement, a copy of all alterations of rules, new rules, and changes of officers made by the trade union during the year, and a copy of the rules of the trade union, must be sent to the registrar. Every such trade union and every officer thereof, failing to comply with or acting in contravention of these requirements, are both liable to a penalty not exceeding $£ 5$ for each offence. Every person who wilfully makes or orders to be made any false entry in or omission from a general statement, or in or from the return of such copies or alterations of rules, is liable to a penalty not exceeding $£ 50$ for each offence $(a)$. Failure to Generally, a trade union which fails to give
transmit required documents. any notice or send any document, which it is required to give or send to the registrar, or every person who, being bound by the rules thereof to give or send the same, likewise so fails, is liable to a penalty of not less than $£ 1$ and not more than $£ 5$, and to an additional penalty of the like amount

(a) (1871) 34 \& 35 Vict. c. 31 , s. 16. 
for every week during which such failure continues $(a)$. If there be no such person, then every member of the committee of management of the union, unless proved either to have been ignorant of the duty to give such notice or send such document, or to have attempted to prevent such failure to give or send the same, is liable to the like penalty. Such penalty is recoverable at the suit of the chief or any assistant registrar, or of any person aggrieved.

The chief registrar must lay annual reports before Parliament with respect to the matters transacted by the registrars in pursuance of the Annual report of registrar to Parlia. Trade Union Acts $(b)$.

The rules of every registered trade union must provide for the manner of dissolving the same. ment.

Notice of dissolution under the hand of the secretary and seven members, in a form prescribed, must be sent within fourteen days thereafter to the central office (in the case of registered trade unions doing business exclusively in Scotland or Ireland, to the assistant registrar of Scotland or Ireland respectively), and such notice of dissolution must be registered by the registrar (c). The words of this section are "the rules of every trade union," i.e. registered or unregistered. "But, since there is no statutory obligation upon an unregistered trade union to have rules at all, and since the effect ofth is section, as applied to an unregistered trade

(a) (1876) $39 \& 40$ Vict. c. 22 , s. 1 .

(b) (1871) 34 \& 3 5ict. c. 31 , (c) (1876) $39 \& 40$ Vict. c. 22 , s. 14 ; Reg. (31) ; for form, vide infra, p. 243.

Dissolution. s. 17 . 
union, would apparently be to compel an unregistered union, if it has rules, to register such rules only as provide for dissolution, and if it has no rules, to make rules providing for dissolution, the provisions of this section would, in all probability, be considered by the Court to apply to a registered trade union only.

Property All property belonging to a registered trade trustees. union must be vested in the trustees $(a)$ for the time being. In the case of a branch of a trade union the property may be vested in the trustees of the branch, or, if the rules of the trade union so provide, in the trustees of the trade union (b). All such property must be under the control of the trustees (or their executors or administrators, according to their respective claims and interests). The words of the Act are "all real and personal estate whatsoever," which mean in effect all property generally; ${ }^{1}$ and "the property, so held, is the property of the union; the union is the beneficial owner." 2 It is not necessary that the trustees should be members of the union. ${ }^{3}$

1 Curle v. Lester, (1893) 9 Servants, [1901] A. C. 416, at T. L. R. 480 ; Linaker v. Pilcher, p. 444. (1901) 84 L. T. 421.

8 Per Lord Davey, in York-

2 Per Lord Lindley in Taff shire Miners Association, [1905] Vale Railway Company v. A. C. 256, at p. 271. Amalgamated Society of Railway

(a) No member under twenty- s. 8 ; (1876) 39 \& 40 Vict. c. 22, one may be a trustee, treasurer, or a member of the committee of management, (1876) $39 \& 40$ Vict. c. 22 , s. 9.

(b) (1871) $34 \& 35$ Vict. c. 31 , s. 3, vide Cope v. Crossingham, [1909] 2 Ch. 148, at p. 158. As to the rights of trustees to sue and be sued, etc., vide infra, pp. 174 et seq. 
Upon the death or removal of trustees $(a)$ the New property of the trade union vests in the succeeding trustees. trustees precisely as in their predecessors. No conveyance nor assignment is necessary, except in the cases of stocks and securities in the public funds of Great Britain and Ireland, in which case such stocks and securities must be transferred into the names of the new trustees.

There is special provision made for the case of a person who is or has been the trustee of a trade union or any branch thereof, in whose name, as trustee, any stock transferable at the Bank of England or Bank of Ireland is standing (either jointly or solely). In the event of such person-

(1) being either absent from Great Britain or Ireland ; or

(2) becoming bankrupt; or

(3) filing any petition ; or

(4) executing any deed for liquidation of his affairs, or for composition with his creditors ; or

(5) becoming a lunatic; or

(6) being dead; or

(7) being unknown to be alive or dead; or

(8) being removed from his office of trustee; the registrar, on written application (in a prescribed form $(b)$ ) from the secretary and three members of the union or branch, on proof satisfactory to him, may direct the transfer of the stock into the names

(a) As to the removal of 11th edition, chapter 30 . trustees, see Lewin on Trusts, (b) For form, vide infra, p. 241. 
of any other persons as trustees for the union or branch. The transfer must be made by the surviving or continuing trustee, and, if he refuses or is unable to make the transfer, or if there be no such trustee, then, if the registrar so directs (such direction being in a prescribed form (a) ), the transfer must be made by the accountant-general or deputy or assistant accountant-general of the Bank of England or the Bank of Ireland, as the case may be. The Governors and Companies of the Bank of England and Bank of Ireland are indemnified against any claim or demand in duly executing duties arising from the registrar's direction $(b)$.

Rights and Duties of Registered Trade Unions.

Accounts. A trustee of a registered trade union is liable for moneys actually received by him on account of the trade union, but is not otherwise liable to make good any deficiency which may arise in the funds of the trade union $(c)$. The treasurer (or other appointed officer) of a registered trade union must render, either to the trustees or to the members at a meeting of the trade union, a just and true account of all moneys received and paid by him since he last rendered an account, a like account of the balance then remaining in his hands, and of all bonds and securities of the trade union. Such account must be rendered by him at such times as the rules require, or upon his being expressly required to do so. The trustees must appoint some

(a) For form, vide infra, s. 4 ; Regs. (17) to (20). p. 242 .

(b) (1876) $39 \& 40$ Vict. c. 22 , s. 10.

(c) (1871) $34 \& 35$ Vict. c. 31 , 
fit and proper person or persons to audit such accounts. The treasurer, if so required, must, after the audit, forthwith hand over to the trustees the balance displayed by the audit, and must also, if required, hand over to the trustees all securities and effects, books, papers, and property of the trade union in his possession. If he fails to do so, the trustees may sue him in any competent Court for the balance of the account displayed by the audit and for all moneys since received by him on account of the trade union, and for the securities and effects, books, papers, and property of the trade union. In such an action the treasurer may set off such sums as he has disbursed on account of the trade union, and the trustees in such action are entitled to their full costs as between solicitor and client (a).

Moreover, if any officer, member or other person, being, or representing himself to be, a member of a registered trade union or the nominee, executor, administrator, or assignee of a member thereof, or any person whatsoever, by false representation or member. imposition, obtain possession of any moneys, securities, books, papers, or other effects of such trade union, or, having the same in his possession, wilfully withhold or fraudulently misapply the same, or wilfully apply any part of the same to purposes other than those expressed or directed in the rules of such trade union, such officer, member, or other person may be ordered by the Court $(b)$ to deliver up all such moneys, securities,

Wrongful possession of property of trade union by officer or mentor

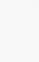
(a) (1871) $34 \& 35$ Vict. c. 31 ,
competent to make such an ค. 11 .

(b) As to which Courts are order, infra, pp. 181 et seq. 
books, papers, or other effects to the trade union, or to repay the amount of money applied improperly, and to pay, if the Court think fit, a further sum of money not exceeding $£ 20$, together Criminal with costs not exceeding $20 s$. In default of such remedy. delivery of effects, or repayment of such amount of money, or payment of such penalty and costs, the Court may order the person convicted of such default to be imprisoned, with or without hard labour, for any time not exceeding three months $(a)$. 'The trade union, or, in Scotland, His Majesty's Advocate, may also proceed criminally by indictment against the party; but no person may be proceeded against by indictment, unless a conviction has been previously obtained for the same offence $(b)$. "Summary remedies for misapplications of the trade union's property are provided, but there is nothing to oust the jurisdiction of the superior Courts." 1

Remedies alternative.

Where any such person has suffered imprisonment for such offence, he cannot afterwards be sued civilly $(c)$. If the union "elect to have recourse to the remedy provided by section 12 of the 1871 Act, the claim of the society against the defendant is satisfied by his conviction by the Court." 2 Conversely, if he has been sued civilly,

1 Per Lord Lindley, Taff Vale Railway Company v. Amalgama. ted Society of Railway Servants,

(a) Despite the Summary Jurisdiction Act, 1879 (s. 6), the debt is not a civil debt and the power of commitment, therefore, can be enforced. $R$. v. I'ruscott, (1900) 81 L. T. 188.

(b) (1871) $34 \& 35$ Vict. c. 31 ,
[1901] A. C. 426, at p. 444.

${ }^{2}$ Per Field, J., Knight v. Whit. more, (1885) 53 L.'T. 233, at p. 234.

8. $12 ;(1876) 39 \& 40$ Vict. c. 22, s. 5 .

(c) It is doubtful how far this statement applies to Scotland: see Agnew v. Addison, (1893) 20 R.i(J.C.), a case, however, where the union was unregistered. 
in the absence of fraud, he cannot be prosecuted criminally. In Madden v. Rhodes, ${ }^{1}$ where an officer of a trade union against whom fraud was not alleged, withheld the money of the trade union, it was considered that the language of the section sanctioning prosecution was substantially the same as that of section 24 of the Friendly Societies Act, $1855^{2}$, and as under the latter section, a civil remedy is given against the treasurer (as is also the case under section 9 of The Trade Union Act, 1871) ${ }^{3}$, it was held by the Divisional Court (Lord Alverstone, C.J., Ridley and Darling, JJ.) on analogy, that the penal remedy should only be applied when the conduct complained of partakes of fraud in some way. The case of United Builders Labourers Union v. Stevenson ${ }^{4}$, if correctly reported, is inconsistent with the contention in Knight $\mathrm{v}$. Whitmore that the remedies are mutually exclusive. In the former case, a defaulting officer was successfully sued after having been convicted. This decision cannot be regarded as authoritative. The defendant was not represented by counsel, and the conviction was obtained under the Falsification of Accounts Act, 1875 (a).

1 [1906] 1 K. B. 534.

2 Per Lord Alverstone, C.J., ibid., at p. 537 .

(a) The Falsification of Accounts Act (1875) 38 \& 39 Vict. c. 24 , above referred to, affords protection both to registered and unregistered trade unions; it enacts that any person (employed by a trade

T.U.
3 Barret v. Markham, (1872)

7 L. R. C. P. 405.

4 (1906) Times, February 7th.

union) who, with intent to defraud, mutilates or destroys a book, security or account of the union or makes a false entry in an account, is liable to penal servitude for seven years or imprisonment for two years. The 
Knight v. Whitmore was, apparently, not cited. It would seem, therefore, that, the civil and criminal remedies are mutually exclusive.

It would appear that an unregistered trade union may also prosecute for embezzlement of its property. ${ }^{1}$

Purchase of land.

A registered trade union or branch thereof may purchase or take upon lease (in the names of its trustees) any land not exceeding one acre. It may also sell, exchange, mortgage or let the same. No purchaser, assignee, mortgagee, or tenant is bound to inquire whether the trustees have authority to perform any of these transactions, and the receipt of the trustees is a sufficient discharge for the money arising therefrom $(a)$.

A registered trade union has power to acquire land by paying for it, but cannot take land by devise. ${ }^{2}$ In Re Amos, Carrier v. Price, North J., held that the power to purchase or take on lease land, given by section 7 of the 1871 Act to a registered trade union, means a power to acquire property by purchase, or by taking a lease of it. The word "purchase," in that section, does not have the meaning of acquiring otherwise than by descent or escheat. ${ }^{2}$ It would seem, however,

1 R. v. Stainer, (1870) L. R. 1 C. C. R. $230 ; R$. v. Tankard, [1894] 1 Q. B. 548.

Larceny Act (1868) $31 \& 32$ Vict. c. 116 (supra, p. 13) in so far as it is applicable, operates in like manner; and enables the beneficial co-owners of property to be prosecuted for stealing or embezzling their common property, vide Hornby v Close (1867),
2 Per North, J., in Re Amos Carrier v. Price, [1891] $3 \mathrm{Ch}$. 159 , at p. 165.

2 Q. B. 153.

(a) (1871) 34 \& 35 Vict. c. 34 , s. 7; by Local Government Board Circular (1908), March 23rd, local authorities are urged to lend their suitable buildings to trade unions for meetings. 
that an unregistered trade union apparently is not capable of taking land at all. ${ }^{1}$

A registered trade union is exempt from income tax in respect of moneys arising out of real estate (Schedule A) ; interest, etc. payable out of public Income $\operatorname{tax}$ exemption. revienue (Schedule B), or other sources not being profits from public employment or the occupation of lands (Schedule D); where such moneys are applicable and are applied solely for the purpose of provident benefits. Provident benefits include any payment to a member of the union during sickness, while he is out of work, or when he is aged, or any payment for tools or funeral expenses. The exemption only extends to cases where the amount assured by the rules of the union does not exceed $£ 300$, or the amount of an annuity granted to any member or his nominee does not exceed $£ 52$ per annum $(a)$. The claim for exemption should be made in the same manner as in the case of an exemption claimed in respect of income applied to charitable purposes $(b)$.

By the Friendly Societies Act, $1896(c)$, a registered trade union or its branch may contribute to the Contribution to funds of, and take part (by delegates or otherwise) in medical society. the government of a society which relieves sickness by providing attendance and medicine; though by so doing, it does not become a friendly society. The trade union, if desirous of withdrawing from such society, must give the society three months'

1 Re Amos, Carrier v. Price, [1891] 3 Ch. 159.

(a) (1893) 56 \& 57 Vict. c. 2, (b) See Pratt on Income Tax, s. 1 ; (1910) 10 Edw. VII. c. 8, 8th edition, chap. ii. s. 70 .

(c) $(1896) 59 \& 60$ Vict. c. 25. 


\section{LEGAL POSITION OF TRADE UNIONS.}

notice and pay all contributions due at the end of that period, to the medical society $(a)$. The contributing trade unions or branches do not become members or branches of the society to which they contribute. A dispute between a trade union and such a society cannot be referred to arbitration under the rules of the latter. ${ }^{1}$

Nomination.

A member of a registered trade union, not being under the age of sixteen years, may, by writing under his hand, delivered at, or sent to, the office of the trade union, nominate any person not being an officer or servant of the trade union (except the husband, wife, father, mother, child, brother, sister, nephew, or niece of the nominator), to whom any moneys (not exceeding $£ 100$ ), payable on the death of such member shall be paid at his decease $(b)$. Such nomination may be partly printed, and, if made in a book kept at the office, is deemed to be delivered at such office $(c)$.

If a member of a registered trade union, who is entitled from the funds thereof to a sum not exceeding $£ 100$, dies intestate, without leaving any subsisting nomination at the time of his death, such sum is nevertheless payable, without letters of adminstration. The person, to whom this sum is to be paid, is the person who appears to a majority of the trustees, upon evidence deemed

\section{Snell v. Vine, (1890) F. S. Cas. 313.}

(a) (1896) $59 \& 60$ Vict. c. $25, \quad$ s. 3.

s. $22(2),(3)$.

(b) (1876) 39 \& 40 Vict. c. 22 , s. 4.

(c) (1883) $46 \& 47$ Vict. c. 47 , s. 10 ; (18s3) $46 \& 47$ Vict. c. 47 , 
satisfactory by them, to be entitled by law to receive it $(a)$.

If a member of a registered trade union, not being under the age of sixteen years, is illegitimate and has died intestate, without leaving any such nomination, the trustees may pay the sum which such member may die possessed of, to the person or persons who, in the opinion of the majority of such trustees, would have been entitled thereto, if such member had been legitimate. If there be no such persons, the deposit must be dealt with as the 'Treasury may direct $(b)$.

All payments made by trustees under these powers are valid against persons claiming as nextof-kin or representative of the deceased. But such next-of-kin or representative may recover money paid by the trustees from the recipients $(c)$.

In Crocker v. Knight, ${ }^{1}$ it was held by the Court Crocker v. of Appeal (Kay and Lindley, L.JJ.), that section 4 Knight. of the 1871 Act prevents the Court from entertaining legal proceedings to enforce the foregoing provisions as to nomination. The plaintiff, the widow of a member of a registered trade union, had been nominated by her husband to receive his funeral money from the society. Lindley, L.J., Lindley, said: " "The sum, sought to be recovered here, is L.J.

1 [1892] 1 Q. B. 702.

2 1bid., at p. 707.

(a) (1883) $46 \& 47$ Vict. c. 47 , moneys available for nominas. 7 .

(b) Ibid., s. 8.

(c) Ibid., s. 9. For the provision as to prevention of frauds on the revenue in respect of tion, and for provisions in respect of nomination in the Channel Islands and the Isle of Man, vide (1883) 46 \& 47 Vict. c. 47 , ss. 10 and 11. 
payable under a rule which provides a benefit to a member within section 4 of the 1871 Act. So far, therefore, this action cannot be maintained $(a)$; but section 10 of the 1876 Act is in terms one, which seems to impose a statutory obligation on the trade union to pay to the nominee the amount to which the member was entitled under the rules. The question is whether the words, 'the trade union shall pay,' constitute an obligation which can be enforced by action. Now I think the object of this section was not to depart from the policy of the 1871 Act, but was entirely different, namely, to enable persons of sixteen years of age and upwards, without the necessity of making a will and incurring the expense of probate, to give away any small sums of money, that may be due to them from the trade union. Under section 10, the money recoverable by a member from the trade union is to go to the nominee of that member, even though he may be so young as seventeen or eighteen years of age, and I do not think, looking at the first and other sections of the 1876 Act, that we can find any sufficient indication of any intention to depart from the terms of section 4 of the 1871 Act, so as to alter the policy of the Legislature, which was to prevent the introduction of legal proceedings into the affairs of trade unions, and to save trade unions from being subjected to the expense of litigation."

"The question" continued his Lordship, "really turns on the construction of the two Acts. We

(a) Infra, Chapter V. 
are asked to read section 10 of the second Act as overriding section 4 of the first, and to hold that there is, therefore, a distinct statutory obligation on the part of the trade union to pay; but when we are told by the Legislature to read the two Acts as one $(a)$, we must read them in such a way as to make them consistent. In my opinion, the trade union is súbject to no more obligation to pay than it was before the Act of 1871 was passed." Kay, L.J., in concurring, said:" "If section $10 \mathrm{Kay}$, L.J. of the 1876 Act had meant to repeal section 4 of the 1871 Act, I should have expected to find in it some such words as 'notwithstanding anything contained in section 4 of the principal Act, such nominee shall be entitled to sue."

In view, however, of subsequent decisions on the construction of section 4 of the 1871 Act, in limiting the jurisdiction of the Courts in inter-union affairs it is extremely doubtful how far Crocker v. Knight may now be regarded as good law (b).

No change of name on the part of a registered Effect of trade union will affect any of its rights or obligations. Any pending legal proceedings may be change of name and amalgacontinued by or against the trustees of the trade union or any other officer who may sue or be sued on behalf of such trade union notwithstanding its new name, and no amalgamation of trade unions will prejudice the right of a creditor of any amalgamating union $(c)$.

$$
{ }^{1} \text { [1892] } 1 \text { Q. B. 702, at p. } 708 .
$$

(a) (1876) $39 \& 40$ Vict. c. $22, \quad$ (c) (1876) $39 \& 40$ Vict. c. 22 , s. 1.

(b) Infra, Chapter V. ss. 11,12 . 


\section{CHAPTER III.}

DIREC'T INTERFERENCE WITH THE DISPOSAL OF LABOUR AND CAPITAL.

Liability THE execution of the purposes of trade unions

for

interference with labour or capital. involves extensive interference with the free disposal of labour and capital, and certain legal liabilities have, in consequence, attached to such associations, "for he that hinders another in his trade or livelihood is liable to an action for so hindering him." 1 The liabilities which have thus attached to trade unions may conveniently be grouped under two general heads :-

(1) Liabilities arising from direct interference with the free disposal of labour or capital ;

(2) Liabilities arising from trade unions acting generally in "restraint of trade" $(a)$.

Direct Interference.

Individual With regard to direct interference with the free and concerted disposal of labour or capital, two distinct sources interference. of liability arise, namely :-

(a) Liabilities arising from individual interference of one or more persons with the free disposal of labour or capital.

${ }^{1}$ Per Holt, C.J. in Keeble v. Hickeringill, (1809) 11 East 574, at pp. $57 \tilde{0}, 576$.

(a) Infra, Chapter IV., Restraint of Trade. 
(b) Liabilities arising from concerted interference of two or more persons with the free disposal of labour or capital.

The liabilities arising both from individual and concerted interference may be divided into two and civil concerted interference may be divided into two liability. classes, namely-(i.) Criminal liabilities and

$$
\text { (ii.) Civil liabilities }(a) \text {. }
$$

Immunities from liability for direct interference have been conferred upon trade unions by the Trade Disputes Act, $1906(b)$, which expressly saves trade unions from certain consequences which formerly attached to them, but such immunities are limited to interference in cases where a "trade dispute" is in contemplation or furtherance.

The words "trade dispute" are specifically defined by the 1906 Act as "any dispute between employers and workmen (that is, all persons employed in trade or industry, whether or not in the employment of the employer with whom a trade dispute arises), or between workmen and workmen, which is connected with the employment

(a) The common law of wrong:ful interference, unqualified by statute, is still in operation in most parts of the United States of America, but in the States of Maryland, California and Oklahoma, Acts analogous to the Conspiracy and Protection of Property Act, 1875, and the Trade Disputes Act, 1906, restrict the common law.

(b) (1906) 6 Edw. VII. c. 47.
The immunity conferred by the 1906 Act is not retrospective, and will not prevent the continuance of an action against a trade union which was com. menced before the passing of the Act. Smithies v. National. Association of Operative Plasterers and others, [1909] 1 K. B. 310 ; Russell \& Co. v. United Soriety of Boilermakers, (1907) 1 ๖ S. I. T. 118.
Immunities under Trade Disputes Aet, 1906.

Meaning of contemplation or furtherance of a trade dispute. 
or non-employment, or the terms of the employment: or with the conditions of labour of any person $(a)$. The words "trade dispute" as also the words "in contemplation or furtherance," immediately preceding them in the Act, must be construed strictly. 'To constitute a "trade dispute" a mere personal quarrel or grumbling or an agitation will not suffice. It must be something fairly definite and of real substance. ${ }^{1}$ In order that a dispute may be a trade dispute at all, a workman must be a party to it on each side, or a workman on one side and an employer on the other. The term "trade dispute" does not necessarily include every case of personal difference between any one workman and one or more of his fellows. It is true that after a certain stage even such a dispute, although originally. grounded, it may be, upon personal animosity, may come to be a subject in which sides are taken, and may develop into a situation of a general aspect containing the characteristics of a trade dispute, but until it reaches that stage a "trade dispute" does not necessarily exist.?

The words " in contemplation or furtherance" do not necessarily embrace every act done by a person with a view to bringing about a trade dispute. ${ }^{3}$ To contemplate a trade dispute is to have before the mind some objective event or situation, but

1 Per Loreburn, I.C., in at p. 517.

Convay v. Irade, [1909] A. C. ${ }^{8}$ Vide Cozens-Hardy, M.R., j06, at p. $50 \mathrm{~s}$.

${ }^{2}$ Per Lord Atkinson, ibid., p. 249.

(a) (1906) 6 Edw. VII. c. 47 , s. 5 (3). 
does not mean a contemplation, meditation or resolve in regard to something as yet wholly within the mind and of a subjective character. And the term "furtherance of a trade dispute" must apply to a trade dispute in existence, and the act done must be in the course of it, and for the purpose of promoting the interest of either party or both parties to it." The words " in contemplation or furtherance " are in the Conspiracy and Protection of Property Act, 1875 ; they mean either a dispute is imminent and the act is done in expectation and with a view to it, or that the dispute is already existing and the act is done in support of one side to it. ${ }^{2}$ It is help, assistance and encouragement to a dispute that the Legislature apparently had in view when it used the words "in furtherance"-must it not, when it uses, in juxtaposition with these words, the words " in contemplation," be held to have had in view a dispute which must, at the time the act it designed to protect was done, have been, at all events, "thought of " by some person who should be a party to it when it arose. ${ }^{3}$

These immunities, conferred by the 1906 Act, apply, whether the original liabilities for individual interference were incurred under statute or at common law.

Criminal Liability for Unconcerted Interference.

With regard to criminal liability, the various Peaeeful forms of interference, generally termed "picketing,"

1 Per Lord Shaw, [1909] A. C. ibid., at p. 512. 506, at p. 522.

${ }^{2}$ Per Lord Loreburn, L.O., at p. 517. picketing lawful where there is a trade dispute. 
are, under certain conditions, legalised $(a)$. It is provided that, in contemplation or furtherance of a trade dispute, it is lawful for one or more persons, acting on their own behalf, or on behalf of a trade union, or of an individual, employer or firm, to attend at or near a house or place where a person resides, or works, or carries on business or happens to be, provided they so attend merely for the purpose of peacefully obtaining or communicating information, or of peacefully persuading any person to work or abstain from working $(b)$.

Communi cation of information apparently unlawful where there is no trade dispute.

Where there is no trade dispute in contemplation or furtherance, attendance at or near the place where a person happens to be in order merely to obtain or communicate information, though formerly expressly exempted from illegality by the proviso of section 7 of the Conspiracy and Protection of

(a) On this section, the Attorney-General, Sir John Walton, said, in introducing the Trades Disputes Act into the House of Commons, "The right of peaceful persuasion is an essential part of the right to strike. The law at present is in an absurd position. It is held to be perfectly lawful to point out to the men what are the points of difference. You may either ask for information with regard to the strike, or you may give them information with regard to the reason of the conflict between the workmen and the employer. But, if you go one step further and so present the information you give them as to make your appeal in the nature of persuasion you are then violating the law."

The Attorney-General further pointed out that this section only revived the law of 1859 , which excepted peaceful persuasion from the offences of molestation and obstruction contained in the Act of 1825, a law which the Act of $187 j$ had been said to repeal. (Parl. Debates, 4th series, 154, col. 130.)

(b) (1906) 6 Edw. VII. c. 47 , s. $2(1)$. 
Property Act, 1875 (a), would now, owing to the repeal of that proviso, seem to be unlawful $(b)$.

The immunity afforded by the 1906 Act must be strictly limited to peaceful picketing. Watching and besetting, or trespass, or any other improper Watching and act is still unlawful. The Trade Disputes Act of 1906 and the 1875 Act must be read together, or rather the latter Act must be read as amended by the former. The seventh section of the 1875 Act was partially repealed by the 1906 Act, and section 7 of the 1875 Act must be read as if section 2 of the 1906 Act was embodied in it. The former Act relates to besetting or watching which is plainly an external operation. " The words in the second section of the 1906 Act are in like manner to be read in connection with the words besetting and watching, thus indicating what may be lawfully done without, but not within, a house or place. It was not intended to enlarge the field of operations - the physical area of the operations of representatives of trade unions or of others. It was never intended to authorise as a matter of right an

(a) (1875) 38 \& 39 Vict. c. 86 . the repeal of that part of the

(b) (1906) 6 Edw. VII. c. 47, 1875 Act, which specifically s. 2 (2). This is evidently an error in drafting, for while the immu. nity bestowed by s. 2 of the 1906 Act, extends only to picketing in contemplation or furtherance of a trade dispute, the 1875 Act has no such limitation. S. 7 of the 1875 Act would embrace the case of besetting a man's house with a view to compel him not to receive guests or visitors. The consequence, therefore, of allows attending to obtain or communicate information, is apparently to restrict rather than to extend immunities to picketing, where there is no contemplation or furtherance of a trade dispute, though this was obviously not the intention of the framers of the 1906 Act. As to the liabilities of trade unions on this head apart from the 1906 Act, vide infra, p. 63. 


\section{LEGAL POSITION OF TRADE UNIONS.}

invasion into a man's house or entry against the will of the owner. ${ }^{1}$ The section refers to a mere "attending" which is more temporary than "watching." The immunity does not extend to a "watching" purposing to compel a person to do an act. ${ }^{2}$

When picketing is not lawful.

Otherwise, apart from the exemptions contained in the Trade Disputes Act, 1906, the statutory criminal liabilities of trade unions for picketing and similar forms of individual interference are contained in the Conspiracy and Protection of Property Act, $1875(a)$.

1 Per Lord O'Brien, L.C.J., in Larkin v. Belfast Harbour Commissioners, [1908] 2 Ir. R., K. B. D. 214, at p. 219.

(a) (1875) 38 \& 39 Vict. c. 86. The circumstances which led to the passing of this Act were as follows. It was undoubtedly the intention of the framers of the Trade Union Act of 1871 , to make the reasonable activities of a trade union lawful. The sidenote to s. 2 of that Act states that "Trade unions are not criminal," and another Act passed in the same year (34 \& 35 Vict. c. 32 ) expressly limited intimidation to cases where a magistrate would have power to convict; but in $R$. v. Bunn and others (1872), $12 \mathrm{Cox}$, C. C. 316 , tried a year after the passing of the Trade Union Act, 1871, Isord Esher gave to the offence of molestation such an extended scope as to make practically all striking
2 Per Palles, J., in $R$. v. Wall and others, (1907) 21 Cox, C. C. 401 , at p. 403.

and collective bargaining unlawful, for, said his Lordship in that case, " it is improper molestation, if anything is done with an improper iutent which the jury might think was an unjustifiable annoyance and interference with the masters in the conduct of their business, and which, in any business would be such annoyance and interference as would be likely to have a deterring effect upon masters of ordinary spirit." His Lordship pointed out that s. 2 of the 1871 Act, which frees trade unions from certain criminal liabilities, applies only to actions criminal as being in restraint of trade, and in R. v. Hibbert and others, (1873) 13 Cox, C. C. 82, it was held, that if the molestation 
Section 7 of the 1875 Act, provides that-

Every person who, with a view to compel any other person to abstain from doing or to do any act which such other person has a legal right to do or abstain from doing, wrongfully and without legal authority,-

1. Uses violence to or intimidates such other person or his wife or children, or injures property ; or,

2. Persistently follows such person about from place to place; or,

3. Hides any tools, clothes, or other property owned or used by such other person, or deprives him of or hinders him in the use thereof ; or,

4. Watches or besets the house or other place where such other person resides, or works, or carries on business or happens to be, or the approach to such house or place; or,

5. Follows such other person with two or more other persons in a disorderly manner in or through any street or road,

shall be liable either to pay a penalty not exceeding Penalty. twenty pounds, or to three months "hard labour $(a)$. Save on a first offence, the penalty if imposed cannot be reduced to less than $£ 5(b)$.

This seventh section imposes liabilities in summary was carried on in such a manner the decision in $R$. v. Ilibbert, was as to give rise to apprehension, pronounced, the Conspiracy and and was done with a view to Protection of Property Act, coerce, it would be a crime. The effect of these decisions went far to nullify the freedom conferred upon trade unions by the Trade Union Act, 1871 ; as a consequence, in the same year as 1875 , was enacted.

(a) Infra, Chapter VI., Procedure.

(b) (1875) 38 \& 39 Vict. c. 86 , s. 8 ; (1879) $42 \& 43$ Vict. c. 49 , s. 4 . jurisdiction. 
substitution for and not in addition to any liabilities for the like offences at common law. It gives " in respect of some nuisances, as to which there was already a civil remedy, a summary remedy by summons before the magistrate" (a), and "criminal prosecutions under it are limited to cases so tortious as to give a civil remedy also." ${ }^{1}$ Where immunities have been conferred by the statute, as in the case of peaceful communication of information, "to hold that the very same acts which are expressly legalised by statute remain, nevertheless, crimes punishable by the common law, would be contrary to good sense and elementary principle." ${ }^{2}$ The section creates only one offence, the various subheadings merely setting out different ways of committing the offence. ${ }^{3}$

Nature of compulsion.

A person on whom compulsion is exercised is protected whether he be a master or a workman. ${ }^{4}$ The compulsion complained of must be done wrongfully and without legal authority. The word "wrongfully" is not superfluous ; the Legislature inserted the word "wrongfully" expressly, because it did not wish the Court to put that restrictive meaning on the word compel. ${ }^{5}$ To issue bills, asking men not to work during a strike,

1 Per Vaughan Williams and Moulton, L.JJ., in Ward, Lock $\&$ Co., $L d$. v. Operative Printers Society and another, (1906) 22 T. I. R. 327 .

2 l'er Lord Coleridge in Gibson v. Lauson, [1891] 2 Q. B. 545, at p. 560 .

${ }_{3}$ Wilson v. Renton, (1909) 47 S. L. R. 209.

${ }^{4}$ Lyons v. Wilkins (No. 2),
[1899] 2 Ch. 255.

5 Per Fletcher Moulton, L.J., in Ward, Lock \& Co., Ld. v. Operative Printers Society and another, (1906) 22 T. L. R. 327. A conviction will not, however, be quashed because the word "wrongfully" is omitted from the complaint. Clarkson $\nabla$. Stuart, (1895) 22 R. (J.) 5.

(a) Vide Chapter VI., Procedure. 
is not a compulsion to make another abstain from doing a legal act, ${ }^{1}$ nor is it compulsion to issue a bill asking union men to boycott a particular person ${ }^{2}$; but to issue a general "black list" of non-union men, apparently, is compulsion. ${ }^{3}$

Section 16 of the 1875 Act declares that nothing Applicain the Act shall apply to seamen or sea apprentices. tion to "Seamen" means persons employed under and subject to the Merchant Shipping Acts, ${ }^{4}$ that is every person (except masters and pilots) employed on board any ship $(a)$. The exemption merely means that seamen cannot be made liable to punishment under the Act, ${ }^{5}$ it does not prevent them from bringing an action. $^{6} \quad$ Similar offences, when committed by seamen, are punishable under the Merchant Shipping Act, 1894, section 236, with a fine of $£ 10$.

With regard to the offence of intimidation, the word "intimidate" is to be interpreted according of "intimito the circumstances which may arise from time to time, but in any event, intimidation, to become unlawful, must at least be such as would justify a magistrate in binding over the intimidator to keep the peace towards the person intimidated. ${ }^{7}$ To constitute intimidation, personal violence must be

1 Peto v. Apperley, (1890) 35 Sess. Papers 880 ; R. v. Cole, Sol. J. 792.

2 Haile v. Lillingstone, (1890) 55 J. P. 676.

${ }^{3}$ Trollope $\nabla$. London Building Trades Federation, (1895) $72 \mathrm{~L}$. T. 342 .

${ }^{4} R$. v. Lynch, [1898] 1 Q. B. 61.

${ }^{5}$ R. v. Wall, (1890) 112 O.C. C. (1891) 13 C. O. C. Sess. Papers 622 ; R. v. Phillips, ibid.

- Kennedy v. Cowie, [1891] 1

Q. B. 771.

${ }^{7}$ Gibson v. Lawson, [1891] 2 Q. B. 545; Curran v. Treleaven. ibid., 553 ; R. v. McCartny, [1903] 2 Ir. K. B. D. 146.

(a) $57 \& 58$ Vict. c. 60 , в. 742.

T.U. 
used. ${ }^{1}$ The intimidation used need not result in such compulsion as would induce serious apprehension of violence in a man of ordinary courage, if the intimidation is such as would justify a binding. over of the intimidator to keep the peace. ${ }^{2}$ But an intimidating letter to an employer that his shop would be picketed, in language so threatening as to make such employer afraid, does not amount to "intimidation." Nor is it intimidation within the reasonable construction of the statute to threaten an employer that workmen will be told to cease work, without, however, using violence. ${ }^{4}$ To communicate to a master a resolution of a union as to the number of apprentices he might employ is not an intimidation. ${ }^{5}$ The test is a subjective one. ${ }^{6}$

Meaning of " persistent following."

With regard to the offence of "persistently following a person from place to place," a man must not be dodged from place to place, so as to interfere with his personal liberty to do what he likes.' To follow another down two streets, and when he crosses the street to cross after him, without speaking to him, has been held to be an unlawful "persistent following." ${ }^{8}$ The essence of

1 Per Cave, J., in $R$. v. McKeevit in Connor v. Kent, [1891] 2 Q. B. 545, at p. 550.

2 Agnew v. Munro, (1891) 18 R. (J. C.) 22.

'Gibson v. Lawson, [1891] 2 Q. B. 545, reversing Judge v. Bonnet, (1887) 36 W. R. 103.

- Per Lord Coleridge, C.J., in Curran v. Treleaven, [1891] 2 Q. B. 545 , at p. 562.

- Wood v Bowron, (1866) 2
Q. B. 21.

- Per Lord O'Brien, L.C.J., in R. v. McCarthy, (1903) 2 Ir. L. R. 146, at p. 156 .

7 Per Huddleston B., in $R$. v. Bauld, (1876) 13 Cox, C. O. 282, at p. 283.

8 Smith v. Thomasson (1890), 62 L. T 68 ; Vegelahn v. Gurther, (1896) 167 Mass. 92, discussed all the English cases to that date as to "persistent following." 
the offence is not the following of a person in a disorderly manner, but such a following as to prevent a person doing such acts as he has a right to do. ${ }^{1}$

With regard to the offence of "watching and besetting," men have no right to watch or beset the house where a person happens to be for the Meaning of "watching and besetting." purpose of compelling him to abstain from doing that which he has a legal right to $\mathrm{do}^{2}$ As to picketing generally, it would appear that, except where a trade dispute is in furtherance or contemplation, picketing may be illegal. Picketing, when it really means improper watching and besetting, is illegal. ${ }^{3}$ At the same time, picketing is not an offence unless it is shown that the pickets have wrongfully and without legal authority done some one or more of the five sets of acts specified in section 7.4 "Watching and besetting" to be wrongful need not be extended in time nor occur in a particular place; a mere attending may thus be wrongful under the 1875 Act $^{5}$; nor need the persons watched and beset be actually employed at the time. ${ }^{6}$

Where a person employed by a body $(a)$, who have

1 R. v. Mackenzie, [1892] 2 United French Polishers Society, Q. B. $519 ; R$. v. Wall, (1910) 21 Cox (Ir.) 401; M'Kinlay v. Hart, (189S) 25 R. (J.) 7 .

a $P$ er Huddleston, B., in $R$. v. Bauld, (1876) 13 Cox, C. C. 282. 3 Lyons v. Wilkins (No. 1), [1896] 1 Ch. S11; ibid., (No. 2), [1899] 1 Ch. 255; Wallis v.

(a) Such body must publish this penalty in their works, otc. It is an offence against the Act

(1905) Times, Nov. 28.

4 Charnock v. Court, [1899] 2 Ch. 35; Walters v. Green, [1899] 2 Ch. 696.

5 Lyons v. Wilkins(No. 2), ibid.

6 Farmer v. Wilson, (1900) 69

L. J. Q. B. 496.
Unlawful breaches of contracts concerning gas and water supply. to fail to publish or for any person to deface notice of the penalty. 
the duty of supplying any place with gas or water, wilfully and maliciously (a) breaks a contract of service with that body, knowing or having reasonable cause to believe that the probable consequences of his so doing will be to deprive the inhabitants of that

Unlawful breaches of contract involving destruction of property.
Interference lawful when there is a trade dispute. place of gas or water, or where a person wilfully and maliciously breaks a contract, knowing that the probable consequences of his so doing will be to endanger human life, or cause serious bodily injury, or to expose valuable property, whether real or personal, to destruction or serious injury, he is liable either to be fined twenty pounds or be imprisoned for three months with hard labour $(b)$. A person procuring such an offence is probably likewise guilty of a misdemeanour $(c)$. The malice need not be directed against the owner of the property concerned $(d)$.

\section{Civil Liability for Unconcerted Interference.}

With regard to civil liability where a trade dispute is in contemplation or furtherance, an act done by a person is not actionable on the ground only (a) that it induces some other person to break a contract of employment, or (b) that it is an interference with his employment, or (c) that it is an interference with his right to dispose of his capital

(a) I.e., purposely; (1875) 38 bo reduced to loss than $£ 5$, \& 39 Vict. c. 86 , s. 15 ; (1861) ibid., s. 8; (1879) $42 \& 43$ Vict. $24 \& 25$ Vict. c. $97 ; R$. v. Clemens, [1898] 1 Q. B. 556.

(b) (1875) $38 \& 39$ Vict. c. 86 , s8. 4 \& 5. Savo on a first offence, the penalty, if imposed, cannot (c) (1861) $24 \& 25$ Vict. c. 94.

(d) $(1875) 38 \& 39$ Vict. c. 86 , 8. 15 ; (1861) $24 \& 25$ Vict. c. 97 , s. 58 . 
or labour as he wills $(a)$. It is, however, otherwise if there are threats or violence, because there is then an independent cause of action, that is, there is some other ground of action besides only the ground that it induces some other person to break a contract and so forth. ${ }^{1}$

It is doubtful whether the existence of malice in inducing another to break his contract affects the immunity $(b)$. Malice may or may not be used to denote ill-will, but if all that is meant by malice is an intention to commit an unlawful act without reference to strife or ill-feeling, its existence probably does not affect the immunity. ${ }^{2}$

Where no trade dispute is in contemplation or furtherance, two sources of liability at common law for individual interference may be distinguished:

Procurement of breach of contract.

(a) Liabilities arising from procuring a breach of contract.

(b) Liabilities arising from preventing persons entering into contracts.

With regard to the first class, it is at common law a violation of legal right to interfere with contractual relations recognised by law, if there be no sufficient justification for such interference, ${ }^{3}$

1 Per Lord Loreburn, L.C., in Convay v. Wade, [1909] A. C. 506, at p. 511.

2 Vide Lord Lindley, in South Wales Miners' Federation v. Glamorgan Coal Co., [1905] A. C. 239.

(a) (1906) 6 Edw. VII. c. 47 , s. 3.

(b) During the debate in
- Per Lord Macnaghton, in Quinn v. Leathem, [1901] A. O. 495 , at p. 510 ; soe also Lumley v. Gye (1853), 2 E. \& B. 216 ; Bowen จ. Hall, (1881) 6 Q. B. D. 333 ; Temperton v. Russell, [1893] 1 Q. B. 715.

committee on this section, Sir Charles Dilke proposed to add to the section "whethor or not 
but the contractual relation must be an enforceable one before this liability can accrue. ${ }^{1}$ As to what amounts to sufficient justification, regard may be had to the nature of the contract broken, the position of the parties to the contract, the grounds for the breach, the means employed to procure the breach, the relation of the person procuring the breach to the person who breaks the contract, and the object of the person in procuring the breach, but no general rule beyond this can be laid down. ${ }^{2}$ It is doubtful whether the fact of a prior contract between $\mathrm{A}$. and $\mathrm{B}$., inconsistent with a subsequent contract between $\mathrm{A}$. and $\mathrm{C}$., is a sufficient justification for the procuring by $B$. of the breach of contract between A. and C. ${ }^{3}$ But the existence of a rule among certain employers not to employ men on strike is an answer to the complaint of a man of procurement of dismissal by such an employer after a strike has broken out. ${ }^{4}$

Preven-

tion of the formation of contract.

With regard to the second class, it is unlawful at common law, by illegal means, to prevent persons from entering into contracts as to the employment of labour or capital if there be no sufficient justification for such prevention. Everyone has the right

1 De Francesco v. Barnum, (No. 1), (1890) 45 Ch. D. 430.

2 Per Romer, L.J., in Glamorgan Coal Co. v. South Wales Miners' Federation, [1903] 2 K. B. 545, at p. 573 ; per Stirling, I.J., ibid., at p. 577.

malice be alleged," but Sir John Walton said he did not think the words were required.
3 Read v. The Friendly Society of Operative Stonemasons, [1902] 2 K. B. 732.

4 Bulcock v. St. Anne's Master Builders' Federation, (1902) 19 T. I. R. 27.

(Parl. Debates, Fourth Series, 156, col. 157.) 
to employ his labour or capital as he will $(a)$; he may earn his own living in his own way. ${ }^{1}$ 1llegal means include any acts of violence or threats of violence, ${ }^{2}$ and may include moral intimidation by exercise of the pressure of numbers $(b)$, as, where a person, controlling the conduct of many in order indirectly to intimidate A., prevents them from working for $B$., thereby exercising pressure upon $\mathrm{A}^{3}$; or illegal means may take the form of publishing a "black list," containing the names of recalcitrant men, thus preventing them from being employed. ${ }^{4}$

What constitutes sufficient justification is a when question of degree and must be defined in each justified. case. It must be left to the Court to determine on which side of the line the ease falls. ${ }^{5}$ Without malice, to protect one's own legitimate trade or labour interests may be a justification, ${ }^{6}$ but the motive of vengeance may exclude the justification. To prevent a man from getting employment in order to make him pay a fine, is not justifiable, ${ }^{7}$ though

1 Per Lord Lindley in Quinn v. Leathem, [1901] A. C. $495 ; R$. v. Batt, (1835) 6 A. R. \& P. 329.

2 Garret v.Taylor, (1792) Cro. Jac. 567 ; Keeble v. Hickering, (1705) 11 East. 574; T'arleton v. McGawley, (1793) 1 Peake 270.

s Quinn v. Leathem, [1901] A. C. 495 .

4 Trollope v. London Building Trades' Federation, (1895) 72L.'T. 342.

(a) "Trado Unions" (Erle).

(b) Which intimidation must be carefully distinguished from
5 Per Bowen, L.J., in Mogul Steamship Co. v. McGregor, Gow \& Co., (1889) 23 Q. B. D. 596, at p. 618 ; Jenkinson v. Nield, (1891) 8 T. L. R. 540.

${ }^{6}$ Scottish Co-operative Society v. Glasgow Fleshers Association, (1898) 35 S. L. R. 645 ; Pink v. Federation of Trades and Labour Unions, (1893) 67 L. T. 258.

7 Giblan v. National Labourers' Union, [1903] 2 K. B. 600.

concerted intimidation or conspiracy. 
if done with just cause and excuse, such prevention may be justified." 1

Lawful interference.

On the other hand, where no contract or other legal right is interfered with in any way, though the act done by the defendant may be one both calculated and intended to inflict upon the plaintiffs great loss and suffering, it is not actionable. It does not matter what the particular act interfered with is, so long as it is not one which the person doing it has a definite legal right by contract, or by common law or statute law to do. ${ }^{2}$ For, under these circumstances, if mere evil motive were to make that unlawful which would otherwise be lawful, ${ }^{3}$ or if, to do intentionally that which is calculated in the ordinary course to damage another, were actionable, it would lead to singular results. ${ }^{4}$ One who committed an act, not in itself illegal, but attended with consequences detrimental to several other persons, would incur liability to those he intended to injure, and the rest of them would have no remedy. ${ }^{5}$ On the other hand, it is very desirable to guard against the notion that, if the act of interference be illegal, just cause may still be averred to purge the wrong. The cause of intervention might be just, but the means used to

1 Peto v. Apperley, (1890) 35 Allen v. Flood, [1895] 2 Q. B. Sol. J. 792 ; (1890) Haile v. 21.

Lillingstone, 55 J. P. 676 ; Hutley v. Simmons, [1898] 1 Q. B. 181; McElrea v. United Society of Drillers, (1905) Times, Feb. 17.

2 Per Wills, J., in Allen v. Flood, [1898] A. C. 1, at p. 51.

${ }^{3}$ Per Lord Wshor, in Temperton v. Russell, [1893] 1 Q. B. 715 ;
4 Per Bowen, L.J., in Mogul Steamship Co. v. McGregor, Gow \& Co., (1899) 23 Q. B. D. 598.

5 Per Lord Watson, in Allen v. Flood, [1898] A. C. 1, at p. 100; see also José v. Metallic lioofing Company of Canada, [190S] A. C. 814 . 
enforce it might be illegal. . . . The use of illegal means evidences malice, and in this connection malice is not equivalent to without just cause. ${ }^{1}$

But for the 'Trades Disputes Act, 1906, a trade Trade union would be liable for the wrongful acts of their servants in interfering with the legal rights of others. ${ }^{2}$ It is provided that no action shall be union not liable for tortious acts of its entertained by a Court against a trade union (whether of workmen or masters), or against any members or officials thereof acting on behalf of themselves and all the other members, in respect of any tortious act alleged to have been committed by or on behalf of the trade union $(a)$. This immunity does not affect the liability of the trustees of a trade union to be sued in the events provided for by the 'Trades Union Act, 1871, section 9, except in respect of any tortious act committed by or on behalf of the union in contemplation or in furtherance of a trade dispute $(b)$. Section 9 of the 1871 Act applies only to the trustees of a registered trade union, who are thereby authorised, if the rules so provide, to bring

1 Per Collins, M.R., in Read v. The Friendly Society of Operative Stonemasons, [1902] 2 K. B. 732.
${ }^{2}$ Taff Vale Railway Co. v. Amalgamated Society of Railway Servants, [1901] A. C. 426. (a) (1906) 6 Edw. VII., c. 47 , s. 4 (1). It is notorious that s. 4 of the 1906 Act was passed to reverse the law as it was declared by Lord (then Mr.) Justice Farwell, and by the House of Lords in the case of 'Taff Vale Railway Co. v.
Amalgamated Society of Railway Servants; per Darling, J., in Bussy v. Amalgamated Society of Railway Servants and Bell (1908), 24 T. L. R. 437.

(b) Ibid., s. 4 (2); supra, p. 44 infra, pp. 174 et seq. agents. 
or defend any action concerning the property of the trade union. It appears, therefore, that

(1) The trustees of an unregistered trade union, and

(2) The trustees of a registered trade union, without rules authorising the bringing and defending of actions, and

(3) The trustees of a registered trade union with such rules, when acting in contemplation or furtherance of a trade dispute,

do not render a trade union liable in respect of their tortious acts.

Generally, the immunity conferred upon trade unions for the tortious acts of their servants by the 1906 Act applies whether there is a trade dispute or not. ${ }^{1}$ But an action will still lie against trade union officials personally for tortious acts unconnected with a trade dispute $(a)^{2}$.

\section{Criminal Liability for Concerted Interference.}

Effect of combination.

It is the common characteristic of all trade unions that they exist for the purpose of combined action. A trade union is defined by statute as a combination, and legal consequences, which would not be produced by the act of a single individual, may ensue from this fact.

1 Bussy v. Amalgamated Society of Railway Servants and Bell, (1908) 24 T. L. R.

(a) The general question as to the right of trade unions, to sue and be sued in the name of their officials, etc.,
437.

2 But see Rickards v. Bartram, (1909) 25 T. L. R. 181.

and thoir legal position with regard to their officials and servants, is discussed under Procedure, Chapter VI. 
With regard to criminal liability, it is provided I that the purposes of any trade union shall not, by reason merely that they are in restraint of not oriminal. $^{\text {nat }}$ trade, be deemed to be unlawful, so as to render any member of such trade union liable to criminal prosecution for conspiracy $(a)$, and with regard to acts done in contemplation or furtherance of a trade dispute, an agreement or combination by two or more persons to do or procure to be done any act in contemplation or furtherance of such "trade dispute" is not indictable as a conspiracy, if such act committed by one person would not be punishable as a crime $(b)$. The law relating to any offence against the State or Sovereign is unaffected by this immunity $(c)$.

\section{Civil Liability for Concerted Interference.}

With regard to civil liability, where a trade dispute is in contemplation or furtherance it is provided that an act done in pursuance of an agreement or Effect of combination on act otherwise combination is not actionable, unless the act would be actionable if done without any such agreement or combination $(d)$, and even where no such dispute exists, it appears clear from recent decisions that where no action will lie against an individual, no action will lie against a combination for similar acts done by them collectively. ${ }^{1}$ That is, the addition

1 Kearney v. Lloyd, (1891) 26 Gregory v. Duke of Brunswick, L. R. Ir. 268 ; the case of (1843) 6 Man. \& G. 205, which is s. 2.

(a) (1871) 34 \& 35 Vict. c. 31 ,

(b) (1875) 38 \& 39 Vict. c. 86 , s. 3 ; (1906) 6 Edw. VII. c. 47 , ss. $1 \& 5(3)$.

(c) (1875) 38 \& 39 Vict. c. 86 , s. 3.

(d) (1906) 6 Edw. VII. c. 47 , ss. 1,5 (3). 
of conspiracy will not make an otherwise lawful act unlawful. ${ }^{1}$

Strikes per Strikes, therefore, and similar combinations to
se lawful. better the conditions of labour, are not in themselves unlawful at common law. There is no foundation for the proposition that strikes are per se illegal or unlawful by the law of England. It is true that occasional dicta are to be found to the effect that combinations to better the conditions of labour are unlawful at common law, ${ }^{2}$ but the Courts have never accepted the law thus laid down, and eminent judges have expressed views to the contrary. Throughout the seventeenth and eighteenth centuries no Court treated combinations to better the conditions of labour as being contrary to common law, and none of the series of legislative enactments, resisting attempts of workmen to better the conditions of labour, purported to declare or rest upon the common law. If we except an obiter dictum by Grose, J., in Rex v. Mawbey ${ }^{3}$ (which was not intended to refer to the common law, but to the effect of statutes then in force), there were no judicial dicta in support of the suggested proposition until after the Legislature swept away all those

often cited against this proposition is not in point; in that case organised hissing of an actor was held to be a conspiracy, and the case was decided on the question of malice (per Coltman, J., ibid.), and it is actionable for an individual to hiss maliciously.

1 Huttley v. Simmons, [1898]
1 Q. B. 181 ; and vide Memorandum of Royal Commission on Trade Disputes, 1906.

2 Notably Hillon v. Eckersley (1856), 8 E. \& B. 47 ; Walsby v. Anley (1861), 30 L. J. M. C. 121 ; per Kay, L.J., in Lyons v. Wilkins, (No. 1), [1896] 1 Ch. 822 , at p. 828.

${ }^{3}$ (1796) 6 T. R. 619, 636. 
statutes by the eombination Aet of $1825(a)$. . . Conclusions as to the common law which first appear in recent times, and are based upon no accepted principle of earlier date, are to be looked upon with great suspicion. Ever since 1824 the weight of authority is against this doctrine. Strikes per se are eombinations neither for accomplishing an unlawful end, nor for accomplishing a lawful end by unlawful means. ${ }^{1}$ The law is clear that workmen have a right to combine for their own protection, while the purpose of the combination is to obtain a benefit which by law they ean claim. ${ }^{2}$ The power of ehoice in respect of labour and terms, which one may exercise and declare singly, many, after consultation, may exereise jointly, and they may make simultaneous declaration of their choice, and may lawfully act thereon for the immediate purpose of obtaining the required terms $(b)$.

The maintenance of a strike is not necessarily illegal, ${ }^{3}$ and if a strike has taken place, in breach of contract, but the broken contracts have expired, Maintenance of strikes, when those who help to maintain the strike by supporting the workmen after their current contracts have expired in a refusal to enter into new contracts of service on new terms, are not doing anything illegal. ${ }^{4}$

1 Per Fletcher Moulton, C.J., in Gozney v. Bristol Trade and Provident Society, [1909]1 K. B. 901 , at p. 923.

${ }^{2} R$. v. Rowlands, (1851) ј Cox, C. C. 466.

${ }^{3}$ Per Buckley, I.J., in Gozney's case, [1909] 1 K. B. 901, at

(a) Supra, p. 7 . p. 925. Vide Lord Bramwell in Mogul Steamship Co. v. McGregor, Gow \& Co., [1892] A. C. 25, at p. 47 .

- Denaby and Cadeby Main Collieries, Ld. v. Yorkshire Miners Association, [1906] A. C. 384. lawful.

(b) “Trade Unions," Erle. 
But to procure by combination a continuing breach of contract is unlawful. ${ }^{1}$ While there is nothing illegal in a strike, nor in contributing for the support of strikers, it may be attended with circumstances, such as breach of contract or intimidation, which make it illegal.?

Combina-

tions

resulting in injury and combinations to injure.
Combination evidence of unlawful intention.

Thus combinations which result in injury to another may lie unlawful, when the object of the combination is injury; and, if the injury is effected, an action may lie for conspiracy. 'The question to be decided in each individual case is, how far the resulting injury is ancillary to a legitimate combination and how far the combination exists for the purpose of injury. When the object of the combination is to benefit oneself, it can seldom, perhaps it can never, be effected without some consequent loss or injury to someone else. The mere fact that the effect of combination is injurious does not make it unlawful. ${ }^{3}$ The act complained of must amount to the violation of a right; no conspiracy is known to the law which has not for its object the accomplishment of an unlawful act, or which does not involve the use of unlawful means. ${ }^{4}$

But, though combination in itself is not unlawful, yet, as a combination for the purpose of causing injury may be more effective than unconcerted coercion, in this sense, it may be evidence of an

1 Smithies v. National Association of Operative Plasterers, [1909] 1 K. B. 310.

${ }^{2}$ Gozney v. Bristol Trade and Provident Society, [1909] 1 K. B. 901.
${ }^{3}$ Mogul Steamship Co. v. McGregor, Cow \& Co., (1889) 23 Q. B. D. 598.

- Per Bigham, J., in Boots v. Grundy, (1900) 82 L. T. 769, at p. 771 . 
unlawful intention; for a combination may make oppressive or dangerous that which, if it proceeded only from a single individual would be otherwise, and the very fact of combination mays show that the object is simply to do harm and not merely to exercise one's own rights; a man may resist without much difficulty the wrongful act of an individual, but it is a very different thing when one man has to defend himself against many combined to do him wrong. It is, however, the damage wrongfully done and not the conspiracy which is the gist of the action. An apparent conflict is thus presented between two rights that are equally regarded by the law, the right of the employer to be protected in the legitimate exercise of his trade, and the right of the employed to dispose of their labour as seems best to them, provided they do no harm to others. We have to consider what is the legitimate boundary. ${ }^{1}$

Summarizing the salient points of this chapter summary. with regard to interference, it would appear that,

(1) When a trade dispute is in contemplation or furtherance, which dispute must be substantial and imminent $(a)$ :

(a) Members of a trade union may peacefully

1 Per Bowen, L.J., in Mogul at p. 616; Quinn v. Leathem, Steamship Co. v. McCYregor, Gow \& Co., (1889) 23 Q. B. D. 598, [1901] A. C. 495:

(a) Supra, p. 58. 
picket to carry information or to persuade persons to work or not to work, but that they incur liability if they in any way intimidate such person $(a)$.

(b) Members of a trade union may induce persons to break contracts and interfere with the right of persons to dispose of their labour and capital as they will, provided no other ground of action save that of such inducement or interference is urged against them $(b)$.

(c) Acts done by members of a trade union in combination, when not actionable if done by individuals, are not unlawful $(c)$.

(2) But when there is no such trade dispute in contemplation or furtherance;

(a) Picketing is probably unlawful $(d)$.

(b) Members of a trade union may be held liable for procuring breaches of contract, or preventing by illegal means persons entering into contracts, unless they can justify their acts $(e)$.

(c) A combination merely to interfere with another in his trade or labour is not unlawful, unless such interference by one person would have been unlawful $(f)$; but a combination to injure another in his trade or labour may be unlawful $(g)$.
(a) Supra, p. 61.
(e) Supra, p. 70.
(b) Supra; p. 68.
(f) Supra, p. 75.
(c) Supra, p. 75.
(g) Supra, p. 78.
(d) Supra, p. 67, 61 (note b). 


\section{CHAP'TER IV.}

RESTRAINT' OF 'TRADE.

The purposes of a trade union, by reason merely that they are in restraint of trade, are not unlawful, so as to render any member of such trade union liable to criminal prosecution, or so as to render void or voidable any agreement or trust $(a)$.

Before the Trade Union Act, 1871, was passed, Former trade unions were unincorporated societies, not recognised as legal, and in that sense, at least, they illegality of trade unions. were held to be illegal on the ground that their objects were to restrain freedom of trade and were against public policy. Neither Courts of law nor courts of equity would recognise or enforce the rules of such societies or the trusts on which their funds were held. By the Trade Union Act, 1871, trade unions were freed from the illegality which was the consequence of being regarded as against public policy (section 2): Their rules and trusts can no longer be treated as invalid by reason of their being in restraint of trade (section 3). They may be illegal or unenforceable on some other ground $(b)$,

(a) The Trade Union Act Chapter III.), or as being un(1871) $34 \& 35$ Vict. c. 31 , ss. 2 constitutional, and thus contrary and 3 .

(b) E.g., "molestation (vide to public policy.

T.U. 
and, if they are, the Act of 1871 does not in any way legalise or affect them. ${ }^{1}$

Their
rules and Even where proceedings concerning the rules and rules and
trusts en- trusts of trade unions, illegal at common law, can be
forceable. entertained by the Court under section 3 of the 1871 Act, the Court's power to entertain such proceedings does not extend generally to proceedings concerning inter-union arrangements, which are specifically excluded by section $4(a)$. The Court, however, is not prevented from exercising any jurisdiction (with regard to such inter-union arrangements) which it could have exercised prior to the Act of $1871 .^{2}$ The legal position of a trade union, therefore, at common law is in no way altered by the Act of 1871 . It can still, so long as it is a legal association, enforce all agreements, domestic or otherwise, unless invalid on other grounds, and consequently, in deciding whether the Court can or cannot entertain proceedings concerning inter-union arrangements, the question whether such trade union is or is not illegal at common law as being in restraint of trade is still, notwithstanding the enabling sections 2 and 3 of the Act of 1871, of great legal importance, and to this question, therefore, the present chapter is devoted.

Test of legality of trade union.

The illegality of an association, by reason of its acting in restraint of trade, is not to be presumed,

1 Per Lord Lindley in York- at p. 279.

shire Miners' Association v. ${ }^{2}$ Ibid., at p. 281. Howden, [1905] A. C. 256;

(a) (1871) $34 \& 35$ Vict. c. 31 , s. 4 ; infra, Chapter V. 
but must be established by those who rely on it.' It is immaterial for this purpose whether such an association is a trade union or not; the crucial question is whether it is legal or illegal at common law. ${ }^{2} \quad$ The determination of its legality or illegality depends upon whether the object of the association, as indicated by the rules, involves an illegal restraint of trade; and the question whether the rules do involve an illegal restraint of trade depends upon their construction. The construction is for the determination, not of the jury, but of the Court..' A society is not to be found illegal by reason of difficulties in interpreting the rules, but by finding in sufficiently plain language that there are in the rules provisions so in restraint of trade as to render the society illegal at common law. ${ }^{4}$ The law as to restraint of trade is now well settled. Every contract in general restraint of trade without limit is bad, but a partial restraint, limited so as to afford reasonable protection only to either or both of the contracting parties, and so as not to be injurious to the public, is good. ${ }^{5}$

It cannot be said that an association, although its objects, as provided for by its rules, are in restraint

Extent of restraint of trade involving

1 Per Lindley, L.J., in Swaine v. Wilson, (1889) 24 Q. B. D. 252, at p. 259; Osborne v. Amalgamated Society of Railway Servants (No. 2), [1911] 1 Ch. 540, per Fletcher Moulton, L.J., at p. 556.

${ }^{2}$ Per Wills, J., in Old v. Robson, (1890) 62 L. T. 282, at p. 284.

: Y'er Farwell, L.J., in Russell

v. Amalgamated Society of illegality.

Carpenters and Joiners, [1910] 1 K. B. 506, at p. 521.

4 Per Buckley, L.J., in Osborne v. Amalgamated Society of Railway Servants (No. 2), [1911] 1 Ch. 540, at p. 542.

5 Per Farwell, L.J., in Russeli v. Amalgamated Society of Carpenters and Joiners, [1910] $1 \mathrm{~K}$. B. 506, at p. 520 . 
of trade, is necessarily unlawful in any criminal sense. Nor does every restraint of trade render the rules unlawful in the sense of being unenforceable; to have that effect a restraint of trade must be such as in some way to prejudice the interests of the community. ${ }^{1}$ The question whether such rules can be enforced by civil proceedings depends mainly upon their reasonableness with reference to the real and legitimate objects of the association. Rules made for the bona fide purpose of protecting the unds of an association from claims which can be avoided by reasonable care and management, will not be regarded as invalid on the ground that they are in restraint of trade, provided that the rules are not unduly oppressive or obviously detrimental to the public. The restraint of trade, in order to render rules providing for such protection invalid, must clearly be shown to extend beyond what is necessary for that purpose. ${ }^{2}$ Objection- But where some rules are objectionable as being
able and innocent rules ; separability of. in restraint of trade, that circumstance may be insufficient in itself to render the association illegal. If the objects of a society are themselves legal, the introduction of some objectionable rules will at most only have the effect of rendering those particular rules invalid. ${ }^{3} \quad$ And there may be cases in which there might be subsidiary rules providing for objects more or less in restraint of trade, which

1 Russell v. Amalgamated Society of Carpenters and Joiners, [1910] 1 K. B. 506, per Vaughan Williams, L.J., at p. 516 .
2 Per Lindley, L.J., in Swaine v. Wilson, (1889) 24 Q. B D. 252, at p. 261.

3 1bid., per Lord Esher, M.R., at p. 257. 
might not prevent the other rules, free from that objection, being enforced, provided that such subsidiary rules do not go to the main object of the association. ${ }^{1}$ Where one object in the rules is ancillary and subordinate to another and is solely for the purpose of more effectively accomplishing it, the Court may then take the latter as being the real or main object, and consider with regard to the former whether it so alters the primary object of the association as to affect its legal status. ${ }^{2}$

But where rules which, though innocent and lawful in themselves, are inextricably mixed up with Inseparability of. rules illegal as being in restraint of trade, then the illegal portion of the rules is necessarily incorporated into the scheme of the innocent and lawful portion, so that the joint and inseverable fabric stands condemned. Or, where the main purpose of an association is such that a member can hardly avail himself of it without bringing into operation such of its purposes as are in restraint of trade, then such association is unlawful and its rules are unenforceable. ${ }^{3}$ Where, however, the objects of an association, as appearing from the rules, are independent of each other and therefore separable, then such objects are of co-ordinate importance in testing whether the main object of the association is illegal. ${ }^{4}$

${ }^{1}$ Russell v.A malgamated Society of Carpenters and Joiners, [1910] 1 K. B. 506, per Vaughan Williams, L.J., at p. 516.

2 Vide Fletcher Moulton, L.J., in Gozney v. Bristol Trade and Provident Society, [1909] 1 K. B. 901 , at p. 921. s Per Kennedy, J., in Burke v. Amalgamated Society of Dyers, [1906] 2 K. B. 583, at p. 590 .

1 Per Fletcher Moulton, L.J., in Gozney v. Bristol T'rade and Provident Society, [1909] 1 K. B. 901 , at p. 921 . 
Attributes The principle, on which an association may be
of an unlawful pronounced unlawful, depends (1) on whether the
association.

purposes for which the association is formed are unlawful; (2) on whether the means whereby its purposes are effected are unlawful; and (3), assuming either of the foregoing to be unlawful, on whether the illegality be of such a kind as to taint the whole constitution of the association and to make it an unlawful association. ${ }^{1}$ If rules which characterise what the object of the association is indicate that the object, or the method of pursuing it, is inconsistent with public interest, then the character of such rules taken as a whole is such as to render unenforceable the individual rules, which would otherwise have been unobjectionable. ${ }^{2}$

Strikes. It should be observed that strikes are not per se illegal $(a)$, and therefore, rules providing for strikes are not necessarily illegal; nor is there anything illegal in rules providing for contributions in support of strikers. Strikes are combinations neither for accomplishing an unlawful end nor for accomplishing a lawful end by unlawful means. Consequently an association does not necessarily become unlawful by reason of its having the facilitation of strikes as one of its objects. But, though the objects of an association, which are for the purpose of maintaining strikes, are now lawful objects if lawfully executed, still they are not

1 Per Fletcher Moulton, L.J., in Gozney v. Bristol Trade and Provident Society, [1909] 1 K. B. 901 , at p. 918.
2 Per Vaughan Williams, L.J., in Russell v. Amalgamated Society of Carpenters and Joiners, [1910] 1 K. B. 506, at pp. 516 and 517.

(a) Vide supra, p. 76. 
objects as to which agreements concerning them can be enforced by the Court. ${ }^{1}$

\section{Authorities.}

In Swaine v. Wilson and Others, ${ }^{2}$ it was held unanimously by the Court of Appeal (Lord Swaine v. Wilson. Esher, M.R., Lindley and Lopes, L.JJ.) that in fact, none of the rules of the defendant society (which does not appear to have been registered) were illegal as being in restraint of trade; that the society was consequently legal at common law, and that the action was one which the Court could entertain at common law apart altogether from the 'Trade Union Act, 1871 ; and it was beld that, where the general objects of a society are legal, the fact that some of its rules may be illegal as being in restraint of trade does not render it illegal, nor does that fact prevent a member from recovering a sum of money payable to him under a rule of the society which is not illegal.

Lord Justice Lindley observed ${ }^{3}$ that illegality was not to be presumed, but must be established Lindley, by those who relied on it. His lordship said ${ }^{4}$ : "It is to be observed that the particular rule sought to be enforced is not even alleged to be illegal, and that the illegality relied upon is the illegality of other rules and of the objects of the society. . . . It is desirable to ascertain the principles which render rules illegal simply by reason of their

1 Sayer v. Amalgamated Society of Carpenters and Joiners, (1903) 19 T. L. R. 122, at p. 123, and vide infra, p 93.
${ }^{2}$ (1890) 24 Q. B. D 252

8 Ibid., at p. 259.

4 Ibid., at p. 260. 
being in restraint of trade. The general proposition that every society which has rules in restraint of trade is unlawful, i.e., criminal, was denied by the Court in Reg. v. Stainer, ${ }^{1}$ and cannot be supported. ${ }^{2}$ The rules of such a society, although in restraint of trade, are not necessarily unlawful in any criminal sense. Whether such rules can be enforced by civil legal proceedings is quite another matter. . . . If the objects of the society are themselves legal, the introduction of some objectionable rules will, at most, only have the effect of rendering those particular rules invalid. The other rules will notbe affected by them. . . . The test of validity in a case like this is reasonableness with reference to the real and legitimate objects of the society. ${ }^{3}$ Rules made for the bona fide purpose of protecting the funds of the society from claims which can be avoided by reasonable care and management will not be invalid on the ground that they are in restraint of trade, provided the rules are not unduly oppressive or obviously detrimental to the public. To render rules for the above purposes invalid it must clearly be shown that they go beyond what is necessary for these purposes."

"No doubt," his Lordship continued, " if the real object of this society were unduly to fetter trade, its rules might all be tainted by the vice of the object, and none of the rules might be enforceable,

1 (1870) L. R. 1 C. C. 230.

2 Soo also Hilton v. Eckersley (1855), 6 E. \& B.47, atp. 58; Horn by v. Close, (1867) 2 Q. B. 153; per Patteson, J., in Price v. Green,
(1847) 16 M.\& W. 346, at p. 353.

${ }^{3}$ Collins v. Locke, (1879) 4 App. Cas. 674.

4 Tallis v. Tallis, (1853) 1 E \& B. 391 . 
as was the case in Hornby v. Close and Farrer v. Close, ${ }^{1}$ where the Court was equally divided, and where Cockburn, C.J., and Mellor, J., relied on evidence which, in their opinion, showed that the rules were used to support strikes." His lordship analysed the rules which were alleged to be objectionable, and came to the conclusion that they were valid.

Lord Esher, M.R., observed" : "If it were ${ }_{\text {Lorler, }}$

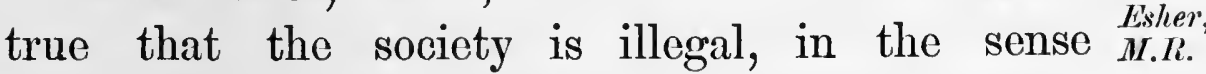
that its object is an illegal object, and any stipulation made by the rules in favour of a member would come into operation in consequence of his assisting in the illegal object of the society, there is no doubt that such a society would be an altogether illegal thing, and the Court could not assist a member of it to enforce any such stipulation. ... If the object of a society were illegal as being in restraint of trade, e.g., if the object were that every nember should assist in establishing and carrying out such a monopoly as would be in restraint of trade and unlawful, and there was a stipulation that every member so assisting should have certain payments made to him, I apprehend that such a society would be so illegal that the Court would not assist a member of it to enforce such a stipulation. 'The question, therefore, is whether this is such a society. It is clear, I think, that it is not. It is a friendly society, the object of which is to assist working people, who are members of it, in old age and

${ }^{1}$ (1867) 2 Q. B. 153, and (1869) 4Q. B. 602.

${ }^{2}(1890) 24$ Q. B. D. at p. 256. 
when they are disabled and out of employment. Therefore its fundamental object is not illegal."

"I think," continued Lord Esher," "even where some of the rules of a society are in restraint of trade, and as such illegal, if the general objects of the society are not illegal, the existence of those rules, though they could not be enforced, would not prevent the enforcement of rules in favour of members which are not in restraint of trade or otherwise illegal. Therefore, as the rule upon which the plaintiff founds his action is not tainted with that vice, and the society is notillegal in its fundamental object, I think he can enforce that rule. This view seems to me to be in strict accordance with the principles laid down in Collins v. Locke ${ }^{2}$ by Sir Montague Smith. But I say further as to this society that I do not think the rules challenged are vicious as being in restraint of trade. I do not think they were intended for that purpose. . . Although, if carried into effect, they may to some extent be in restraint of trade, yet, that not being their object, and their provisions being only sufficient for a legal object, I do not think that we ought to extend the doctrine with regard to restraint of trade so far as to hold them illegal as being in restraint of trade." Lopes, I.J., concurred.

old v. In Old v. Robson ${ }^{3}$ the respondent made a claim Robson. under the rules of a society, which was a registered trade union, to recover a sick benefit relief. IIe contended that, under the Friendly Societies Act, 1875,
${ }^{1}$ (1890) 24 Q. B. D. at p. 257.
2 (1879) 4 App Cas 674 ${ }^{3}(1890) 62$ L. T. 282. 
s. $22(a)$, this was a friendly society. It was held by the Divisional Court (Pollock, B., and Wills, J.), reversing the magistrates' decision, that the objects of the society's rules were illegal, as being in restraint of trade, that the society was therefore illegal at common law, and that consequently the Court had no jurisdiction to entertain the action. Pollock, B., observed that the question was whether the society was a trade union or subPollock, B. stantially a friendly society. He said: " "We have a society which at common law would clearly have been illegal." In referring to the rules in sofar as they related to trade matters, the learned Baron observed that there were powers of fine, of suspension, and even of expulsion of members for violating the rules of the society with reference to these trade questions. He held that at common law the rules were illegal, and that an action concerning their breach could not be entertained by the Court. His lordship concluded in these words: "In the case of Knowles v. Booth ${ }^{2}$ there was no suggestion that the society in question was an illegal society, so that the decision in that case is no authority whatever for supporting the decision of the magistrates in this case." Wills, J., observed" : "It seems to me wills, $J$. that it is immaterial whether this society is a trade union or not; the only question is, whether it is an illegal association at common law. If so, it

1 (1890) 62 T. T., at p. 283.

${ }^{3}$ (1890) 62 L. T., at p. 284.

${ }^{2}$ (1854) 32 W. R. 432.

(a) (1875) $38 \& 39$ Vict. c. 60. 
remains so as to this purpose." His lordship was of opinion that the society was illegal at common law. Commenting upon the rules he observed: "There are various provisions, the objects of which are in restraint of trade. A man shall not carry on his trade as he likes, but must look to the governance of his society. It is clear, therefore, that the society is illegal at common law, and that the incapacity to appear in Court has not been removed by any legislation. The case of Knowles v. Booth ${ }^{1}$ applies to what is a friendly society and no more. It will not do to say that the society is a legal society for some purposes, but illegal for other purposes."

Curiously enough, the case of Swaine v. Wilson (a) was not brought before the notice of the Court. But it cannot be suggested that there is any real analogy between that case and the case of Old v. Robson. In Swaine v. Wilson the Court held that none of the rules were illegal. It is true that there were obiter dicta which laid down the further doctrine that, if the object of a society was legal, the introduction of some objectionable rules would, at most, merely render such particular rules invalid. But there is nothing inconsistent with this doctrine in Old v. Robson. Mr. Justice Wills's expression "that it will not do to say that the society is legal for some purposes, but illegal for others," is not inconsistent when it is remembered that the Court was of opinion that the main object of the society was illegal.
${ }^{1}$ (1884) 32 W. R 432.
(a) Supra, p. 87. 
In Sayer v. The Amalgamated Society of Carpenters sayer v. and Joiners ${ }^{1}$ the plaintiff brought an action against a Amalgaregistered society, which was likewise defendant in Society of Old v. Robson, to recover benefits. Both Swaine v. penters. Wilson and Old v. Robson (a) were brought before the notice of the Court. In holding that he had no jurisdiction to entertain the action Mr. Justice Bruce observed that it was quite clear that the Bruce, $J$. objects of the society were in restraint of trade and to maintain strikes. 'These were now legal objects if carried out in a legal way, but they were not objects as to which agreements concerning them could be enforced by the Court. The authority of Old v. Robson was binding upon him, and it was decided upon the rules of this very society, one of the main objects of which was to promote the organisation of trade, though some of the rules had the objects of a friendly society. Although in Swaine v. Wilson it was decided that the rules were not in restraint of trade, he thought that the dictum of Lord Esher did not apply in this case. This was primarily a society for the organisation of trade, and the rules dealing with the objects of a friendly society were a small part of the whole.

In Cullen v. Elwin and Others ${ }^{2}$ the plaintiff brought an action to recover arrears of superannuaCullen v. Elwin. tion allowance. The Court of Appeal (Collins, M.R., Romer and Mathew, L.JJ.), affirming the judgment of the Divisional Court, held that the main purpose of the defendant society, as appearing from the
${ }^{1}(1903) 19$ T. L. R. 122.
${ }^{2}$ (1904) 90 L. T. 840.

(a) Supra, pp. 87 and 90. 
rules, was illegal, that all the other rules were ancillary to and inseparable from those in restraint of trade, and that the association was therefore Collins, illegal. Collins, M.R., observed ${ }^{1}$ : "The question M.R. here is whether there is anything in the rules of this society which makes it an illegal association at common law. It is possible for societies to frame rules which contain an element of illegality in them without at the same time vitiating the whole system. It is also possible. for them to make rules, which are apparently and ostensibly innocuous, and yet may vitiate the whole system, because, rightly understood and considered as a whole, their innocent parts are merely ancillary to that part which is not in point of law deemed to be legal. The question on which side of the line the particular rules of a particular society fall is a question of fact in each case. ... In Swaine v. Wilson (a) the Court of Appeal, on perusing the rules of the society, were able to arrive at the opinion that there was not such illegality in the rules as to vitiate the whole scheme and render it impossible to enforce them at common law. The rules are summarised in the report of the case, and the critical point was whether they were ancillary to the illegal purpose of the society, or whether the illegal purpose came in only in particular rules, without being so inter-connected and indispensable to the rest as to carry its vicious character through the whole system. 'The Court of Appeal came to

1 (1904) 90 L. T., at p. 842.

(a) Supra, p. 87. 
the conclusion, after looking at the rules, that the illegality was entirely separate from, and not mixed up with, the innocuous part of the rules, and therefore did not vitiate the whole scheme (a). In Old v. Robson the Court, upon reviewing the rules of the society, came to the opposite conclusion (b). In the present instance the question that we have to consider is on which side of the line does this case fall. In Swaine v. Wilson the society purported to be a friendly society. I do not say that that would be conclusive, but the society purported to be a fjiendly society and not a trade union, and the greater number of the rules, on the face of them, were obviously fit rules for carrying out the purposes of a friendly society." His Lordship, after referring to the rules, continued:" "It seems to me that it is perfectly impossible to say that the primary object of this society is not 'trade protection,' as they call it, by the ordinary means employed by trade unions-viz., strikes and so on, which at common law are illegal $(c)$. That is the main purpose of the society, and all these other provisions (in the rules) are ancillary to it." Mathew, L.J., had no doubt that this was not a friendly society. The Mathew, friendly part was only aneillary to the trade union part, and the condition and consideration for

(a) In Swaine v. Wilson (supra, p. 87) the Court in fact held that none of the rules were illegal, and that the objects were notillo. gal (see (1889) 24 Q. B. D., at pp. 252,260 ). The Master of the Rolls would seem to imply that there was illegality of purpose or of rules. It is quite true that the Court of Appeal made obitcr dicta to the effect he states.

(b) Supra, p. 90.

(c) Sed quare, vide pp. 76 and 86. 
granting a superannuation allowance was that the applicant should belong from the first to the trade union. The society had power at any moment to terminate the membership and expel him for interfering with its main objects. Romer, L.J., concurred.

Some extracts from the judgments of the Court Lord
dlverstone, C.J. JJ.) in Cullen.v. Elwin ${ }^{1}$ are given. Lord Alverstone, after coming to the conclusion that the particular rules of this society were illegal, observed that Swaine v. Wilson and Old v. Robson were not inconsistent. He remarked that there was not a single Wills, J. rule which was illegal in Swaine v. Wilson. Wills, J., observed ${ }^{1}$ : "It is perfectly true that a much larger quantity of the rules in bulk relate to friendly society matters rather than matters which relate to trade disputes; but the answer is the very simple one, that the benefits which are assured by a friendly society are inextricably mixed up by the rules themselves with the observance of trade rules, the trade rules themselves being of such a character that I cannot doubt that, according to the principles which have usually been applied, they do amount to rules in restraint of trade. . . ." His Lordship was of opinion that this was a friendly society for the purpose of affording benefits to superannuated members, but with this qualification, that supposing there should be ample funds to meet all the demands of persons entitled to superannuation allowances, yet, if such person had broken one of the trade rules, he might be expelled and might forfeit the whole 
benefit of his contributions to the friendly society. He continued: "How can that be said to be such a society as Lord Esher's observations (sc. in Swaine v. Wilson) apply to? The portions which are objectionable are of express intention and purpose. They are so mixed up with the friendly society part of it that any member who breaks the trade rules is liable to lose everything that he has put into the society. It seems to me that it is quite impossible under these circumstances to say that it is not a society with the most effectual guarantee that the members of it shall observe the rules which are made in restraint of trade." His Lordship was of opinion that Lord Esher's judgment in Swaine v. Wilson had no application to this case. He concluded: "If you cannot separate the one from the other, it seems to me the illegal portion is necessarily incorporated into the scheme of the friendly society portion of the work of the society."

Channell, J., in concurring, observed " : "The main question that we have to consider is whether Channell, $J$. this society by its constitution, as shown by its rules, is, as a matter of law, an illegal society at common law. ..." His Lordship said that this question depended upon the rules, and then proceeded: "It has been held, apparently, that what is to be looked at is the main and substantial object of the society. That seems to me to be the effect of the cases taking them altogether $(a)$. But 1 (1903) 88 L. T., at pp. 688-689.

(a) Butsee Fletcher Moulton, and Provident Society, infra, L.J., in Gozney v. Bristol Trade p. 103.

T.U. 
when we come to consider whether there is any case that gives us a guide as to whether this particular society must be held to come within the category of societies whose object is illegal, so that the society is illegal, or is merely a society some of the rules of which are unenforceable, it seems to me that the case of Old v. Robson is an authority which we are bound to follow to the effect that this is an illegal society."

Burke v. In Burke v. Amalgamated Society of Dyers ${ }^{1}$ the Amalgamated Society of Dyers.

plaintiff, a lunatic's widow, sued a registered trade union for sick benefits alleged to be due to her husband at the date of his death. The Divisional Court (Kennedy and A. T. Lawrence, JJ.) held that the main object of the society was illegal, that the legal and illegal portion of the rules were inseparable, and that consequently the Court could Kennedy, not entertain the action (a). Kennedy, J., observed ${ }^{2}$ : "It is contended that inasmuch as the society is a trade union, and is sued as such, and as its main objects are in restraint of trade, the jurisdiction of the Courts is excluded. The plaintiff, on the other hand, relying on the case of Swaine v. Wilson (b), contends that, although the defendant society is a trade union by reason of the fact that one of its objects is to interfere in the relations of employer and employed, yet the rules are so largely of the type of rules of an ordinary friendly society that

1 [1906] 2 K. B. 583.

2 Ibid., at pp. 589 et seq.

(a) The decision of the Court rested largely on a question of agency.

(b) Supra, p. 87. 
we may properly neglect the other objects of the society, with the result that this action would be maintainable upon the principle illustrated in that decision. No doubt there are in that case weighty expressions of opinion, especially on the part of Lindley, L.J., to the effect that, although a society is a trade union, yet, if its objects are severable into trade union objects and friendly society objects, there may be cases in which an action will lie to enforce an obligation which is not in restraint of trade. This decision may, however, be contrasted with Old v. Robson (a), decided in the following year, where it was held that, the objects of the society not being those of a friendly society, justices had no jurisdiction to entertain the application. . . . We are, of course, bound by Swaine v. Wilson, which was a decision of the Court of Appeal, and which, no doubt, decided that an action would lie where the main object of the society was to provide benefits for its members, although some of its objects might be trade union objects and in restraint of trade. It seems to me a fair inference that, when the main purpose of such a society is such that a member can hardly avail himself of it without bringing into operation the purposes of the society which are in restraint of trade, an action would not lie; but that question it is not necessary now to determine. In the present case I am unable to sever the two classes of objects. The main object was clearly to protect the interests of the workman and to interfere in his relations with his employers,

(a) Supra, p. 90. 
and though no doubt the benefits are not confined to that, but extend to allowances in respect of sickness and accidents, I am inclined to think that the society is illegal."

A. T.

Law-

A. T. Lawrence, J., after making observations rence, $J$. to a similar effect, remarked ${ }^{1}$ : "The argument which was pressed on us with regard to Swaine v. Wilson ignores the fact that in that case the society was not registered under the Trade Union Acts.... In the present case an endeavour is being made to sue a society, which is admittedly a trade union, by its registered name upon an agreement to provide certain benefits for one of its members, and such a claim see ms tome to come within the exact language of section 4 of the Trade Union Act, $1871 "(a)$.

Distinc- This is the first judicial notice which has been
tion

between registered and unregistered trade union raised. taken of the effect of registration or non-registration having any bearing on the legality of a trade union or entertainment of jurisdiction by the Court. His Lordship would seem to imply that the Court entertained jurisdiction in Swaine v. Wilson because the society was not registered under the Trade Union Acts and its objects were in the main lawful, whereas in the present case his Lordship was unable to entertain jurisdiction because the society was a registered one, as well as because he regarded the objects as unlawful and inseverable from the lawful objects.

1 [1906] 2 K. B., at p. 591.

(a) (1871) $34 \& 35$ Vict. c. 31. 
Unfortunately the learned judge does not give the reasons by which he arrived at this conclusion.

In Gozney v. Bristol Trade and Provident Society ${ }^{1}$ Gozney v. the plaintiff brought an action against a registered ${ }_{\text {Trade }}^{\text {Bristol }}$ and trade union, for a declaration as to the construction of some of its rules, which referred to penalties imposed on sick members for being out after hours. He also claimed a declaration that he was right in carrying out the directions of his doctor, and that the defendants were wrong in fining him for so doing, and he claimed for the return of the amount he had been fined. It was unanimously held by the Court of Appeal (Cozens-Hardy, M.R., Fletcher Moulton and Buckley, L.JJ.), reversing the Divisional Court, that the society was legal, that its rules were unobjectionable, and that, even assuming that they were not, the formation and application of the trade funds was distinct and severable from that of the friendly society funds. In commenting upon the rules of the defendant society, Cozens-Hardy, M.R., observed ${ }^{2}$ that there was nothing in the rules which authorised calling Hardy, out members or assisting a strike. Indeed, any such action was expressly prohibited by the rules. $\mathrm{He}$ thought that the society was really a mutual insurance society against sickness and loss of wages by reason of shortness of work (called travelling relief), or by reason of voluntary abstention from work (called strike pay). His Lordship thus concluded: "It is a harmless society, and there is nothing unlawful in its objects. The judgment of 
this Court in Swaine v. Wilson (a) applies to the present case. ... I think this society is just inside the limits of legality."

Fletcher Moulton,

Fletcher Moulton, L.J., was of opinion that L.J. strikes per se were combinations neither for accomplishing an unlawful end nor for accomplishing a lawful end by unlawful means. In order to determine the question whether the society was illegal apart from the Act of 1871 he observed ${ }^{1}$ : "To answer this question it is necessary to examine the purposes for which the defendant society is formed and the means whereby it proposes to effect those purposes. If either of these be illegal, it may be necessary to examine more closely into the nature of that illegality to see whether it is of such a kind as to taint the whole constitution of the society and make it an illegal society. But if there is no illegality in either respect, it is impossible to refuse to it a legal status which would entitle the plaintiff to bring it before the Courts. It follows, therefore, that the question must be decided entirely by an examination of the rules. These rules define its constitution and objects, and set forth the detailed rules adopted by it for carrying out those objects." His Lordship proceeded to comment on the individual rules. He was of opinion that a rule " to regulate the relations between employers and workmen " was neutral in its bearing on the question. It connoted nothing illegal. He then 1 [1909] 1 K. B. 901, at pp. $918 \mathrm{et} \mathrm{seq}$.

(a) Supra, p. 87. 
discussed the effect of the rule, which provided for strike pay. He said: "To understand the matter properly it is necessary to state that the society has two types of subscriptions, the produce of each going into a separate fund. The one is to provide sick pay and the like, and so far as this subscription is concerned the society is for all practical purposes merely a friendly society. But members of the society may, but not must, subscribe to the trade fund and thereby become entitled to trade benefits. The formation and application of this trade fund is therefore a separate and distinct object of the society."

"It was pressed upon us," continued Fletcher Moulton, L.J., " on behalf of the plaintiff that nevertheless it (i.e., the formation and application of the trade fund) was not the main object of the society, and certain authorities were quoted which speak of the main object as that which must be looked to. I do not think that such a contention is sound. So soon as it is clear that one of the objects of a society is a separate and distinct object and that it is carried out independently, no question of its order of importance can have any legal bearing or effect. For all legal purposes such objects are co-ordinate. They possess the same status. It may be different in cases where one is ancillary and subordinate to another and is solely for the purpose of more effectively accomplishing it. The Courts may then take the latter as the real or main object and consider with regard

[1909] 1 K. B., at pp. 920 et seq. 
to the other whether it so alters the primary object of the society as to affect its legal status. But no such question can come in where the objects are independent and therefore co-ordinate, and I shall consider the question arising out of the rule in regard to strikes as though the giving of these trade benefits were a principal object of the society. ... Under the rule in regard to strikes it is provided that, when a strike takes place for the purpose of bettering or defending existing conditions of labour, trade members shall receive strike pay for the first six weeks, and the executive committee are empowered, should the strike continue, to extend this period if after consideration they deem it necessary to do so. Counsel for the defendants contend that these rules by providing for the payment of strike pay facilitate strikes, because strike pay prevents workmen from being driven to abandon them by the imminence of starvation to themselves and their families. This they say is sufficient to make an association which has the giving of strike pay as one of its objects an illegal association independently of the relieving provisions of the Trade Union Acts. This appears to me to be a tremendous conclusion to be based upon such slight premises $(a)$. . . I Icannot see that

(a) The contention of counsel for the defendant, as it appears in the report, was that illegality would apply at common law to any association formed for the purpose of maintaining strikes; that the main object of this society was to protect actual strikers against their masters; that provision was made by the rules for combination with the object of securing by pressure on the employer improved conditions of labour, which was illegal; and that taking over funds, which one member has 
it makes any difference that this object is effected by a specific provision with regard to strikes as, for instance, by an insurance against them, whether on the mutual principle or otherwise. ... What a workman does by becoming a trade member of the defendant society is (so far as this matter is concerned) neither more nor less than to join a mutual insurance society against loss of wages during strikes. But the real fallacy of the argument on the part of the defendants lies deeper. It proceeds on the proposition that strikes are per se illegal or unlawful by the law of England. In my opinion there is no foundation for such a proposition. . . . I therefore come unhesitatingly to the conclusion that the fact that the arrangements for giving strike pay do in a sense facilitate strikes is quite immaterial for the purposes of our decision, and that the defendant society does not become illegal by reason of its having this as one of its objects."

Buckley, L.J., in concurring, observed ${ }^{1}$ : "If the Buckley, general objects of the society are not illegal, it is legitimate, upon the authority of Collins v. Locke ${ }^{2}$ and Swaine v. Wilson (a), to inquire, notwithstanding the existence of some rules which might be in restraint of trade and thus illegal, whether the general objects are not free from that objection. . . . So far as trade benefits are concerned, the rules amount to no more than insurance of the members against the consequences of a strike. Provisions

1 [1909] 1 K. B. 901 , at p. 925. 2 (1879) 4 App. Cas. 674.

subscribed for a particular to other members who were on purpose, and paying them over strike, was illegal.

(a) Supra, p. 87. 
to encourage or procure a strike may be illegal. Provisions for the assistance of the victims of a strike may be perfectly legal. In these rules I can find no provisions addressed to the procurement or even the sanction of a strike. The rules do not, it is true, as did the rules in Swaine v. Wilson, provide that one of the objects shall be to render assistance to members when out of employment, but one rule really points in this direction. It contemplates that a member is in search of work and provides that his allowance shall be stopped if he refuses work at the current rate, except in an event, namely, that he is asked to fill the place of one fighting for better conditions. Here is a scintilla of assistance to maintaining a strike. This may fall into the observations which I have to make upon the principal rule in this connection, namely, the rule in regard to strikes. The effect of that rule, I think, is that, if a strike takes place, members are to have assistance, but that that assistance even is not available in the case of all strikes, but only in support of certain strikes. It is provided that no officer or member shall take any active interest or aid in any way or otherwise assist any trade movement except in his private capacity. This is a direct veto upon procuring or inciting a strike." His Lordship concluded with the observation that there was not in these rules any provision so in restraint of trade as to render the Russell v. society illegal.

Amalgamated Society of Carpenters.
In Russell v. Amalgamated Society of Carpenters and Joiners and Others ${ }^{1}$ an action was brought by a ${ }^{1}$ [1910] 1 K. B. 506. 
widow, as personal representative of her husband, who had been a member of a registered trade union, against the society and the trustees of its funds, claiming sums alleged to be due under the rules providing sick and superannuation benefits for the society's members. It was held unanimously by the Court:of Appeal (Vaughan Williams, Farwell, and Kennedy, L.JJ.), that the main object of the society was illegal at common law as being in restraint of trade, and that the rules relating to its provident purposes were so inseparably connected with that object as to be affected by its illegality, and were therefore unenforceable; and consequently the plaintiff's action to recover benefits was unenforceable. Vaughan Williams, L.J., observed ${ }^{1}$ : "It is not every restraint of trade which will render the provisions of an agreement unlawful, in the sense that it cannot be enforced by action at common law. To have that effect a restraint of trade must be such as in some way to prejudice the interests of the community. It may do that in a case where the freedom of contract of an individual is restricted to an unnecessary extent by an agreement which he has entered into, or in a case where the area, from which employers not parties to the agreement can seek to obtain workmen, is unreasonably restricted. It may be observed, in passing, that it cannot be said in the latter case, as it can in the former, that the restraint of freedom of trade arises in consequence of the voluntary action of the party whose freedom is restrained; 
for in a case where, for instance, the rules of a trade union prohibit their members from working with non-union men, there is a restraint of trade to the prejudice of employers and workmen other than members of the trade union, quite independently of any action of their own."

Vaughan Williams, L.J., continued: "If the expulsion clause contained in the rules be looked at, it will be seen that, if a member of the society refuses to comply with any decision of a managing or branch committee, or of a branch, he may be expelled from the society, and will thereupon lose, not merely a specific amount in which he might be mulcted by a fine or penalty, but all those future benefits from the funds of the society, in the nature of friendly society benefits, which he sought to ensure through subscription to the society. It is impossible, when one is judging of the object of this society, to leave out of consideration the fact that a breach of the trade union rules or directions by a member involves the liability to loss of all the friendly society benefits, for that fact goes a very long way towards the conclusion that the main object of this society is that of a trade union and not that of a friendly society. I come to the conclusion that at common law, and apart from section 3 of the Trade Union Act, 1871, these rules are of such a character that an action would not lie to enforce the benefits in the nature of friendly society benefits thereby provided for, because the whole object of the society is one which involves such a restraint of trade as to 
render its rules as a whole unenforceable, although individual rules, taken by themselves, may be unobjectionable."

After analysing the particular rules which he regarded as illegal, Vaughan Williams, L.J., continued ${ }^{1}$ : "I have now to consider the rules generally, in order to see whether those particular rules are capable of being severed from the rest Inseparability of friendly society purposes from trade union purposes. and treated individually as being in restraint of trade, and therefore unenforceable, without treating the whole object of the association as being such as to render its rules incapable of being enforced. In dealing with this question I desire to point out that this is not a case in which there is a complete separation of the purposes of the society as regards the fund applicable to what I may call friendly society purposes and that applicable to the trade union purposes provided for by the rules. In some cases there have been rules which provided for such separation. This is not such a case." His Lordship thought, moreover, that there might be cases in which there might be subsidiary rules, not affecting the main object of the association, which might be more or less in restraint of trade, and yet might not prevent the other rules of the association, which were free from that objection, from being enforced. "This proposition," he said, " "is one which applies to rules which do not go to the main object of the association. If one finds rules which really by their character indicate the object of an association, and the object so indicated is in its

${ }^{1}$ [1910] 1 K. B. 506, at p. 318.

${ }^{2}$ Ibid., at p. 516. 
nature, or by reason of the manner in which it is to be worked out, inconsistent with the public interest, I think that one is bound to hold that the character of such rules, taken as a whole, is such as to preclude a Court from giving effect to individual rules here and there amongst them, which, taken by themselves, might be unobjectionable." His Lordship was of opinion that there were amongst the rules of this society a considerable number which were clearly in restraint of trade in the sense that they must have operated to the prejudice of the interests of the community.

Authorities reviewed.

Turning his attention to the authorities, Vaughan Williams, L.J., observed ${ }^{1}$ : "The rules of the defendant society have been before the Courts on previous occasions. In each of the cases where the rules at present in force have had to be considered, it appears to have been held that they did involve such an illegality, as being in restraint of trade, that they were unenforceable. . . . I do not believe that anything which I have said in the present case is in any way inconsistent with the decisions in Swaine v. Wilson and Gozney v. Bristol Trade and Provident Society (a). In both of these cases the rules were very different from those in the present case. I decide this case on the ground that, if the rules of this society be taken as a whole, it is plain that the main object of the society is one which involves such a restraint of trade as to render the rules unenforceable. . . . I do not think that the judgment

${ }^{1}$ [1910] 1 K. B., at p. 519.

(a) Supra, pp. 87, 101. 
which I am giving in any way trenches upon the proposition, which is now undoubted, that a strike is not necessarily unlawful, that it is not illegal to persuade men to determine their contracts with their employer lawfully, or not to work for an employer, unless the workmen can obtain some terms for which they are asking. There is nothing to my mind contrary to the rules against restraint of trade in a society's maintaining such strikes by providing them with funds. A strike may of course be so conducted as to be not only unlawful, but criminal, but there is no suggestion here of anything of that kind."

Farwell, L.J., was of opinion that the determination whether the society was lawful depended upon Farwell, L.J. whether the object of the society, as appearing from the rules, involved an illegal restraint of trade. "The law," he said," "as to restraint of trade is now well settled. Every contract in general restraint of trade is bad, but a partial restraint limited so as to afford reasonable protection only to either or both of the contracting parties, and so as not to be injurious to the public, is good." His Lordship then referred to the doctrines in regard to restraint of trade laid down in the cases of Horner v. Graves, ${ }^{2}$ Nordenfelt v. Maxim Nordenfelt Guns and Ammunition Co. (No. 1), ${ }^{3}$ and Underwood \& Sons v. Baker. ${ }^{4}$ He then proceeded ${ }^{5}$ : "The question" (sc. in regard to restraint of trade) "depends upon the construction of the rules, which is for the Court, and not for a jury. The only facts which could be relevant, for

${ }^{1}[1910] 1$ K. B. 506, at p. 520.

¿ (1831) 7 Bing. 735, at p. 742.

3 [1894] A. C. 535, at p. 565 .
4 [1899] 1 Ch. 300, at p. 304.

5 [1910] 1 K. B., at pp. 521 et seq. 
the purpose of assisting the Court in coming to a conclusion on that question, would be facts deposed to by witnesses giving evidence from which the Court could draw an inference whether the restriction imposed on trade was reasonable or the reverse as was explained by this Court in Leng \& $\mathrm{Co}$. v. Andrews. ${ }^{1}$ In the present case there are no facts in evidence to assist us in determining whether the restrictions contained in these rules are or are not reasonably necessary for the protection of parties interested or from the point of view of the public. ... The rules fall under two heads, trade union rules proper and benefit society rules. Now trade unions were, as Lord Macnaghten pointed out in Amalgamated Society of Railway Servants v. Osborne (No. 1), ${ }^{2}$ originally formed for a double purpose, one being a diplomatic and militant purpose, and the other a benevolent purpose. ... The only means by which a trade union can give full effect to the former of these purposes is the power of compelling a strike and rendering assistance to strikers."

Separability of funds and rules.
"It is said," Farwell, L.J., continued," "that, if the rules, by providing for strikes, are thereby illegally in restraint of trade, still the benefit rules are severable, and the plaintiff is suing in respect of rights arising under benefit rules. If there were two distinct sets of rules constituting two distinct contracts with separate funds applicable respectively to militant and beneficent purposes, exclusively each of the other, the case might be different; but there

${ }^{1}:[1909] 1$ Ch. 763.

2. [1910] A. C. 87 , at p. 95 .

${ }^{3}[1910] 1$.K. B. 506, at p. 523. 
are here no separate funds, and nothing to prevent funds standing to the credit of benevolent purposes from being applied to militant purposes, and the two portions of the union are bound together by the indissoluble nexus that members may be entirely expelled from the society and lose all the benefit advantages by reason of some breach of a militant rule. Moreover, this power of expulsion and consequent forfeiture of benefits is of the essence of the trade union, because the union derives therefrom its whole power of effecting its militant purposes as a trade union. A member, who has subscribed to a union, perhaps for years, in order to obtain in the future the benefits in the nature of friendly society benefits provided for by the rules, will naturally hesitate long before he disobeys an order which may involve his expulsion from the union."

Farwell, L.J., commented on the authorities Authothus " : "In Swaine v. Wilson (a), Lindley, L.J., said: $\begin{gathered}\text { rities } \\ \text { reviewed. }\end{gathered}$

'No doubt, if the real object of this society were unduly to fetter trade, its rules might all be tainted by the vice of the object, and none of the rules might be enforceable.' ${ }^{2}$ That to my mind applies exactly to this case. This society is in my opinion a trade union pure and simple, and the fact that it has certain subsidiary objects in the way of benefit to its members does not make it the less so. The paramount object is that of a trade union, and the subsidiary objects cannot be severed from that object. The society in Swaine v. Wilson was really a friendly society, but some of its rules at first

${ }^{1}$ [1910] 1 K. B. 506, at pp. 523-525. $\quad{ }^{2}$ Ibid., at p. 523.

T.U.

(a) Supra, p. 87. 
sight appeared to savour somewhat of a trade union. The Court of Appeal held that, its objects being substantially those of a friendly society, those subsidiary rules did not go beyond what was reasonably necessary for the protection of its funds, and therefore did not make it an illegal association. Gozney v. Bristol Trade and Provident Society (a) comes within the same category. Cozens-Hardy, M.R., said of the society in that case: 'it is a harmless friendly society and there is nothing unlawful in its objects.' Neither of these cases affects the present. . . . The case of Farrer v. Close ${ }^{1}$ does not seem to have much bearing on the present, because it is said that the rules then in force were not the same, and did not contain the provisions in the present rules upon which the defendants rely. As I read it, all the members of the Court thought the rules there in themselves unobjectionable, but two of them took into consideration the course of business which had been followed by the society in acting upon them, and held that, as that amounted to an unlawful restraint of trade, the society was an illegal one." His Lordship thought that Cockburn, C.J., indicated that in that case he would have been inclined to accept the view that the rules were characteristic of a friendly society's rules, had there been nothing to show that the rules in question, in their practical application by the society, had been made subservient to the purposes of a trade union instead of being confined to those of a friendly society. And his Lordship quoted the following remark from the 1 (1869) 4 Q. B. 602.

(a) Supra, p. 101. 
judgment of the Chief Justice: 'I think we are bound to look not only to the rules themselves, but also to the conduct and operations of the society; and that we must treat the society, not according to what it professes to be, but according to what it practically is.' The Chief Justice, therefore, treated the question in that case as depending, not on the construction of the rules, but on the manner in which the funds of the society had actually been applied. "That mode," said Farwell, L.J., "of dealing with the question is contrary to the view which I have expressed, but the point does not really arise in the case now before us."

On the subject of strikes, Farwell, L.J., observed ${ }^{1}$ : strikes. "It was urged before us that a strike may or may not be lawful, and that the Court ought to assume that only lawful strikes are contemplated by the rules of the society. Admitting that it is not to be assumed that an unlawful strike is intended, in the sense of a strike involving criminal or wrongful acts, there is no such assumption with regard to a strike which is in restraint of trade; the very object of a trade union on its militant side is to obtain its end by restraining trade, and, as this has been rendered lawful by the Trade Union Acts, there is no reason for assuming that this is not its real object and purpose. These rules undoubtedly enable such restraint to be applied; thus, the executive body may call out the men on strike for any or no reason, for their good or to their detriment, and regardless of the public

${ }^{1}[1910] 1$ K. B. 506 , at p. $\tilde{2} 22$. 
welfare. ... If the rules are so framed as to give the executive this power, then they are illegal at common law and only good under the Trade Union Act. I cannot doubt that this is their true construction, and the actual intention of the framers thereof."

Kennedy, L.J.

Kennedy, L.J., concurred. He thought that the question here was whether the scheme of the rules constituted the society an illegal one at common law. He observed ${ }^{1}$ : "Speaking generally, what seems to me to be the vice of these rules is that they provide for a restraint of trade, not shown to be reasonable, in that they involve a surrender by the members of the union of their individual freedom of action." $\mathrm{He}$ pointed out that an expelled member was excluded not merely from the benefits under the militant portion of the rules, but also all benefits under the friendly society portion. He thought that the rules involved restraint of the widest and most extreme character, and were inseverable. He adopted the decisions in Old v. Robson (a), Sayer v. Amalgamated Society of Carpenters and Joiners (b), and Cullen v. Elwin (c), and said that his decision was not in conflict with Swaine v. Wilson (d), nor Gozney v. Bristol Trade and Provident Society (e).

Mudd v. In Mudd v. General Union of Operative Carpenters Gnion of and Joiners, ${ }^{2}$ it was held that, on the construction Operative of the defendant society's rules, it was an illegal
Carpenters.

[1910] 1 K. B. 506, at p. 526. ${ }^{2}$ (1910) 26 T. L. R. 518.
(a) Supra, p. 90.
(b) Supra, p. 93.
(c) Supra, p. 93.
(d) Supra, p. 87.

(e) Supra, p. 101. 
association at common law as being in restraint of trade. Coleridge, J., observed " : "If the matter was res integra it might be urged that the law ridge, $J$. should take cognizance of all innocent rules of a trade union, but decline to recognise such rules as are framed for an illegal purpose. But it has been held in Russell v. Amalgamated Society of Carpenters and Joiners (a), that if the objects of the trade union are in any substantial sense illegal, the whole trade union is an illegal association, and none of its rules can be enforced. On the other hand, if the objects of the trade union be in the main legal the fact of the existence of a rule or rules which disclose an illegal purpose, if such rule or rules are not in regard to a main object of the society, will not make the whole society illegal." His Lordship thought that the rule dealing with misconduct and consequent expulsion of members was similar to that in Russell's case, in which it was held that such a rule contemplated such a restraint of trade as to make all the other rules generally, harmless or otherwise, unenforceable at law. "This decision," he concluded, "was grounded on the consideration that there was so strong a persuasion on the members to obey the rules, even contrary to their inclination, through fear of losing the benefits, as to make the rule a rule in restraint of trade, and that, being a dominant rule, it made all the other rules unenforceable." His Lordship thought that it must be clearly shown that the rules having an illegal tendency

$$
1 \text { (1910) } 26 \text { T. L. R., at p. ô19. }
$$

(a) Supra, p. 106. 
were a main feature of the trade union before they could render unenforceable the harmless rules.

Osborne v. In Osborne v. Amalgamated Society of Railway
AmalgaAmalgaSociety of Rail. way Servants (No. 2). Servants (No. 2), ${ }^{1}$ the plaintiff brought an action against a registered society, from which he had been expelled, claiming to be reinstated. On the preliminary objection that the defendant society was an illegal association at common law, and that its domestic agreements were therefore unenforceable, being taken (a), the Court of Appeal (Cozens-Hardy, M.R., Fletcher Moulton and Buckley, L.JJ.), reversing the decision of Warrington, $\mathrm{J} .{ }^{2}$ held that on construction the rules were not illegal as being in restraint of trade, that the society was therefore an association lawful at common law, and that the action was Cozens- consequently maintainable. Cozens-Hardy, M.R., Mar.R. after remarking that there was nothing in the objects of the society, as appearing from the rules, which suggested illegality, observed ${ }^{3}$ : "But, though the objects are free from the taint of illegality, there may be provisions in the rules which seek to advance the objects by unlawful means. It is remarkable that there is no provision, such as is very often found in rules of trade unions, for calling out members in the event of a strike." His Lordship said that illegality must be established upon some plain provisions in the rules, and he

1 [1911] 1 Ch. 540.

${ }^{3}[1911] 1$ Ch., at p. 551.

${ }^{2}$ (1911) 27 T. L. R. 115.

(a) For the legal principles in regard to the unforceableness of the agreement under s. 4 of the Trade Union Act, 1871 ; vide infra, pp. 135 et seq. 
could find no such provision. ${ }^{1}$ He further observed that the executive committee of the society could only sanction, as distinct from ordering, a strike, and that the rules contained careful provisions to secure legality. ${ }^{2}$

Fletcher Moulton, L.J., after stating that the Fletcheronus of establishing the allegation of illegality M.J. Mon, rested on the party relying on it, ${ }^{3}$ observed that the familiar provisions relating to strikes and the power of the society to direct whether men shall or shall not work under particular circumstances, were absent. ${ }^{4}$ His Lordship said that the Courts would not hold an association to be illegal at common law unless it clearly appeared from the rules that its objects were in restraint of trade to an unreasonable extent. He thought that the rules contained no provision in restraint of trade such as would render this association illegal at common law. ${ }^{5}$ Buckley, L.J., was of opinion that, the rules did not provide that when a strike, or, as Buckley, L.J. the rules called it, a trade movement, was sanctioned by the executive committee, every member was bound to strike, nor was such member, if he had struck, bound not to resume work without the executive committee's sanction. ${ }^{6}$ His Lordship concluded ${ }^{7}$ : "A society is not to be found illegal by reason of difficulties in interpreting the rules, but by finding in sufficiently plain language that there are in the rules provisions so in restraint of

${ }^{1}[1911] 1 \mathrm{Ch}$., at p. 553.

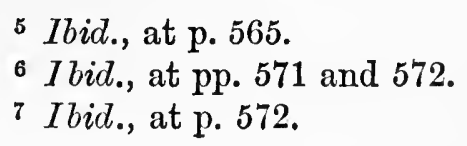

4 Ibid., at p. 564. 
trade as to render the society illegal at common law. Those rules do not, I think, contain anything plain in that direction, and upon this ground I am disposed to think that this society is not illegal."

\section{Authorities Reviewed.}

Comment on authorities.

The association in all the cases under review in this chapter has been held to be illegal with only three exceptions-viz., Swaine v. Wilson, ${ }^{1}$ Gozney v. Bristol Trade and Provident Society, ${ }^{2}$ and Osborne v. Amalgamated Society of Railway Servants (No. 2). ${ }^{3}$. In Swaine v. Wilson, it will be remembered, not only the impugned rule, but all the rules of the association were held to be legal. The obiter dicta, however, of the Court of Appeal laid down some further principles. Provided that the fundamental object of an association or its general objects were not illegal, then only such rules as were objectionable on the ground of restraint of trade were invalid, the test of validity being reasonableness with reference to the real and legitimate objects of the association, and absence of undue oppression or obvious detriment to the public. In Gozney v. Bristol Trade and Provident Society the Court of Appeal likewise, it is apprehended, considered that all the rules were legal, and the like conclusion was arrived at in Osborne v. Amalgamated Society of Railway Servants (No. 2). It would seem that, so long as the purposes of an association

1 (1889) 24 Q. B. D. 252; p. 101. supra, p. 87.

${ }_{2}^{2}$ [1909] 1 K. B. 901 ; supra, p. 118.

${ }^{3}$ [1911] 1 Ch. 540; supra, 
or the means of effecting its purposes are legal, the association is legal. In Swaine v. Wilson the attributes of the association's rules were said to connote those of a friendly society, in Gozney's case those of a mutual insurance or friendly society. In both these cases the trade funds and friendly society funds were held to be severable both as to contribution and application.

It may be safely affirmed from the foregoing cases that neither a strike, nor the sanctioning, contributing to or assisting a strike, is illegal, not Under what circumstances is merely in a criminal sense, but in the sense of illegal? rendering an association unlawful, so as to render its domestic agreements unenforceable. This, however, is a somewhat negative affirmation, and is inadequate to determine the precise point at which a strike or these concomitant factors do render the association illegal in the sense that its agreements are unenforceable. The question is probably one of the degree of restraint of trade involved, but, if it is, the Courts have not, so far, contributed any principles to its solution. 'The Courts have laid great stress on the question whether a member of an association was bound by the provisions for a strike, and have indicated that compulsion in that matter would tend to render the rules and therefore the association illegal. It is submitted that this proposition is not the true solution unless in an indirect sense. Provided the rules are legal, it cannot be said that compulsory obedience will render them illegal. It might, of course, be said that it is the compulsion which renders a compulsory 
strike so obnoxiously in restraint of trade, but this is indirect reasoning from consequences. Either a strike is legal or not. If it is legal it is difficult to see why a rule making it compulsory should be illegal, whereas other compulsory rules, which are legal, are not visited with the same consequences. 


\section{CHAPTER V.}

LIMITATION OF THE COURT'S JURISDICTION.

THe purposes of any trade union, by reason Trade merely that they are in restraint of trade, are not unions' deemed to be unlawful so as to render void or trusts and agreements are voidable any agreement or trust $(a)$. But while the valid, following agreements are not unlawful, no legal proceeding instituted with the object of directly enforcing or recovering damages for the breach of any of them will be entertained by any Court, namely :-

1. Any agreement between members of a trade union as such, concerning the conditions on which any members for the time being of such trade union shall or shall not sell their goods, transact business, employ, or be employed $(b)$ :

2. Any agreement for the payment by any

(a) (1871) 34 \& 35 Vict. c. 31, between the employer and s. 3. Supra, Chapter IV.

(b) The agreements herein contemplated are agreements between members of a trade union as to the conditions of employment, and not as to whether a member shall or shall not be employed. That is to say the conditions are conditions of employment in regard to such things as wages, hours, and bonds, or arrangements employee. They are not conditions upon which a man shall seek employment or return to his trade, but are the conditions of his employment when he is actually employed. Baker (otherwise known as Friendly Society of Iron Founders of England, Ireland and Wales) v. Ingall, [1911] 2 K. B. 132 ; per Phillimore, J., at p. 139.

but certain specified agreements are unenforcable.

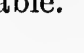


person of any subscription or penalty (a) to a trade union :

3. Any agreement for the application of the funds of a trade union

(a) To provide benefits (b) to members ; or,

(b) To furnish contributions to any employer or workman not a member of such trade union, in consideration of such employer or workman acting in conformity with the rules or resolutions of such trade union; or,

(c) To discharge any fine imposed upon any person by sentence of a Court of justice.

4. Any agreement made between one trade union and another;

5. Any bond to secure the performance of any of the above-mentioned agreements $(c)$.

An agreement based upon an unenforceable agreement may be itself unenforceable.

Though the above agreements are thus rendered unenforceable by the statute, it is doubtful if an agreement based upon them, or one of them, is excepted. Thus if a trade union enter into a contract to pay a member a sum in the event of his becoming totally incapacitated, and under that contract such member signs an agreement that he will repay the said sum in the event of returning to his work, then

(a) It is possible that this sub-section may not comprise all things which would be called penalties at common law, and probable that it is confined to such matters as fines, or exclusion from the trade union, or from benefits, but the subsection does not extend the meaning of the word "penalty." Baker v. Ingall, [1911] 2 K. B. 132. (b) The word " benefit" is limited to such benefits as sick and strike pay; it does not include, for example, indemnity for the costs of an appeal in a compensation case (Lees v. Lancashire andCheshire Miners' Associa. tion, (1906) Times, June 20th).

(c) (1871) $34 \& 35$ Vict. c. 31 , s. 4 . 
the subsequent agreement has been held to be a part or term of the original agreement. ${ }^{1}$ On the other hand, it has been held in Scotland, by the First Division, on appeal, that such subsequent agreement is enforceable, notwithstanding that the original was unenforceable, and that it is immaterial whether the original contract in the rules required the repayment in terms, or only the signing of an agreement to repay. ${ }^{2}$

It will be observed that it is only where at common law the action would not be maintainable, the Court is still, in virtue of section 4, not enabled to entertain it (a). In Swaine v. Wilson, Lord Justice Lindley observed" : This action is brought with the object of directly enforcing an agreement for the Circumstances under which actions fall within the ambit of the 1871 Act. application of the funds of the society to provide benefits to members, and the action is in fact 'a legal proceeding instituted with the object of directly enforcing or recovering damages for the breach of an agreement' of the kind mentioned in s. 4 . Notwithstanding s. 3 of the Act this action therefore cannot be maintained unless it can be maintained independently of that section." "If the action," observed Lord Young," "was a good one at common law, then there was no necessity for the statute, and in the words of the section itself the statute did not require to be appealed to as ' enabling.' All general statutes are framed with

1 Per Vaughan, Williams L.J., (1911) Times, December 2nd, reversing the Divisional Court in Baker v.Ingall, [1911] 2 K. B. 132. ${ }^{2}$ Wilkie v. King (1911), 2 (1880), 7 R. 867.

S. I. T. 206.

${ }^{3}$ (1889) 24 Q. B. D. 252, at p. 259.

${ }^{4}$ In $M \cdot$ Laren v. Miller

(a) Supra, p. 82. 
tacit reference to the common law. ... All the 1871 Act says, in fact, is, that if it would not have been enforceable at common law the statute will give no assistance."

The The operation of s. 4 is lucidly set forth in the jurisdic- following observations of Lord Lindley": "(1) Section prior tion 4 extends not only to Courts of law, but also to 1871 Act is left wholly unaffected.

Courts of equity.

(2) The section does not prohibit any Court from exercising in any case jurisdiction which it could have exercised before the Act passed; the section simply prevents any Court from extending its jurisdiction, and interfering in cases in which the Act would authorise interference if it were not for the direct prohibition contained in the section. (3) No legal proceeding, which might be taken, if the section did not prohibit it, is prohibited except a legal proceeding instituted with the object of directly enforcing, or recovering damages for the breach of the specified agreements. The word ' directly' is important and limits the application of the section. Legal proceedings for other purposes than those specified are not prohibited; although they may indirectly affect agreements on which no action can be brought."

Con-

tractual relations, though lawful, may be unenforceable.

The combined effects of sections 2, 3, and 4 of the Trade Union Act, 1871, are well expressed by Lord Justice Buckley. "Assuming," he said," "a society illegal at common law by reason of having purposes in restraint of trade, 1 In Yorkshire Miners'Associa. Society of Railway Servants tion v. Howden, [1905] A. C. (No. 2), [1911] 1 Ch. 540, at 256, at p. 281. p. 566 .

2 In Osborne v. Amalgamated 
section 2 of the Act renders those purposes lawful in any question of criminal liability for conspiracy. Section 3 renders those purposes lawful in any question of validity of agreement or trust. By virtue of section 3 contractual relations which would have been void for illegality become lawful contractual relations and enforceable accordingly. But this is qualified by section 4. That is a section which lawfully defines certain agreements which may form part of the contractual terms, and enacts that nothing in the Act shall enable any Court to entertain any legal proceeding to enforce those defined agreements. Notwithstanding that section 3 has rendered contractual relations which include such terms lawful, the particular defined agreements are nevertheless to be unenforceable in any Court."

Considerable difficulties have arisen in connection with the interpretation of section 4 , so that its of the proper interpretation can only be pronounced on with diffidence. It may be said that:

1. An action to recover benefit money is unenforceable ${ }^{1}$;

2. An action

(1) claiming a declaration that

(a) a member is entitled to participate in the enjoyment of the property and effects of the trade union, and in its rights, privileges and benefits;

(b) his expulsion was invalid; and

$1 M$ 'Kernan v. United Opera- 1 R. 45̃3; Shanks v. Same, (1874) tive Masons' Association, (1874) 1 R. 823. 
(2) claiming an injunction against expulsion, and

(3) claiming damages,

is unenforceable ${ }^{1}$;

3. An action-

(1) claiming rescission of a resolution of fine and expulsion, and

(2) claiming damages, ${ }^{2}$

is similarly unenforceable.

Actions entertainable ;

On the other hand,

1. An action claiming an injunction against uplifting or applying the funds contrary to the rules, ${ }^{3}$ and

2. An action claiming a declaration that a resolution authorising strike pay is ultra vires and illegal," would appear clearly to be enforceable.

It would seem, too, that

3. An action claiming a declaration, reinstating an expelled member in his membership, is enforceable, though his rights as a member, in so far as affected by section 4 , are unenforceable. ${ }^{5}$

\section{Authorities.}

McKer- In McKernan v. United Operative Masons' Assonan v. United ciation $^{6}$ the pursuer raised an action against the Operative Masons' Association. defendant association and the central committee thereof to recover benefit money which he averred

${ }^{1}$ Rigby v. Connol, (1880) 14 Ch. D. 482.

${ }^{2}$ Aitken v. Associated Carpenters and Joiners of Scotland, (1885) 12 R. 1206.

${ }^{3} M^{\prime}$ Laren $\nabla$. Miller, (1880)

7 R. 867.
4 Yorkshire Miners' Association v. Howden, [1905] A. C. 256.

- Osborne v. Amalgamated Society of Railway Servants (No. 2), [1911] 1 Ch. 540.

6 (1874) 1 R. 453. 
was due to him under the rules of the association. It was held by the Second Division of the Court of Session (Lord Justice Clerk Moncreiff, Lords Benholme and Neaves) that in terms of section 4 of the 1871 Act, the claim could not be enforced in a Court of law. The Lord Justice Clerk (Right Hon. Lord Moncreiff), after reciting the defenders'

Lord

Moncreiff. plea, that the association and its laws, being directed to support strikes of workmen and in restraint of trade, the said laws could not sustain action in a civil Court," observed: "The plea is that the purposes of this association, being in restraint of trade, agreements made in respect of them are void or voidable. It was put from the bar as pactim illicitum " (a) . . It is perfectly clear from the terms of the Trade Union Act, 1871, section 3 , that the intention and object of the Act was to declare the very reverse of that proposition, and that the purposes of a trade union shall not be unlawful so as to render void or voidable any agreement or trust by reason merely that they are in restraint of trade. Granting that the agreements or trusts are neither void nor voidable, are they to be enforced in a civil Court?" His Lordship then indicated that the Court was prevented from entertaining the action because it fell within the excepted agreements of the Act of $1871(b)$.

${ }^{1}$ (1874) 1 R. 453, at pp. 457 et seq.

2 Ibid., at p. $45 \mathrm{~s}$.

(a) A general term applied to all contracts opposed to law, either as being contra legem, contra bonosmores, or inconsistent

T.U. with the principles of sound policy.

(b) (1871) $34 \& 35$ Vict., s. 4 (3) (a). 
Shanks v. United

Operative Masons' Associa. tion.

Lor d d Inglis.

In Shanks v. The Same, ${ }^{1}$ which was identical with McKernan's case, and was similarly decided by the First Division of the Court of Session, Lord President Inglis observed ${ }^{2}$ : "It appears to me that trade unions were unlawful associations before the passing of the Trade Union Act, 1871, in this sense, that actions such as the present could not be legally brought against them in a Court of law. This is made clear by the statute, if it were not so on the decisions prior to its passing. ... The object of the Act is to give relief to trade unions in certain clearly defined directions, to enable them to sue certain actions and enforce certain rights which they could not sue and enforce before. . . . Section 3 enacts that 'the purposes of any trade union shall not, by reason mercly that they are in restraint of trade, be unlawful, so as to render void or voidable any agreement or trust,' that is to say, that agreements made by and with such associations may, notwithstanding the unlawfulness of these associations in other respects, be enforced in Courts of law or equity. The fourth section is really a rider upon this one, limiting the extent of its application. The agreements specified in this section are not to be held as absolutely unlawful, but no Court is to entertain any action to enforce them. This section comprises 'any agreement for the application of the funds of a trade union'-inter alia - 'to provide benefits to members.' Now the action before us concludes for a payment, which the association has, it is alleged, agreed according to its rules and

$$
1 \text { (1874) } 1 \text { R. } 823 .
$$

2 Ibid., at p. 825. 
regulations, to provide to its members in certain events. Now, as the combined result of the common law and of the statute of 1871 , I think there can be no doubt that this action falls under this provision of the fourth section, and consequently that we have no jurisdiction to entertain this case." The other judges concurred.

Rigby v. Connol ${ }^{1}$ is the first English case bearing on this section. The previous Scottish authorities Rigby $\mathbf{}$. were not cited; indeed, Sir George Jessel said that the matter appeared to him to be free from authority. ${ }^{2}$ In that case the rules of a registered trade union provided, inter alia, for fines in the event of a member binding his son in a shop in which non-union men were employed. The plaintiff refused to pay such fine and was expelled. He brought an action against the committee and trustees of the union, claiming for a declaration that he was entitled to participate in the enjoyment of the property and effects of the trade union, and in its rights, privileges, and benefits, and that the pretended expulsion was invalid; and he claimed for an injunction restraining the defendants from excluding him from such participation and for damages. It was held that the action was brought for the purpose of directly enforcing an agreement between members of a trade union "to provide benefits to members" within the meaning of, section 4 (3) (a), and that, apart from the Act, the union was an unlawful association, and the plaintiff was therefore not entitled to any relief. The judgment
${ }^{1}$ (1880) 14 Ch. D. 482.
${ }^{2}$ Ibid., at p. 488.

K 2 
in this case is of considerable importance in view of the fact that a vast number of judgments in subsequent cases have been based on it.

Sir Jeorge Jessel, M.R., after remarking that the basis of the Jessel, $\boldsymbol{M} . \boldsymbol{R}$. Court's jurisdiction to interfere at the instance of a member of a society, in order to prevent his improper expulsion therefrom, rested on the right of property vested in such member $(a)$, observed as follows": "I am satisfied that the agreement contained in the rules is an agreement to provide benefits for members, and that, if I decide in favour of the plaintiff, I directly enforce that agreement, because I declare him entitled to participate in the property of the union, and the only property they have is their subscriptions and fines, and I restrain the society from preventing that participation. It seems to me that is directly enforcing that agreement, in fact, it is in substance directing and enforcing the specific performance of it, nothing more nor less. The only question remaining, therefore, is whether the negative words in this Act 'nothing in this Act shall enable,' really prevent me giving him any relief whatever, because these words do not say that the Court may not otherwise enforce; all the section says is, 'nothing in this Act shall enable.' The question, therefore, which I have to consider is, what would have happened without the Act? And it appears to me that without the Act this is clearly an unlawful association; it is an association by which men are not only

${ }^{1}$ (1880) 14 Ch. D. 482, at p. 490.

(a) Vide infra, pp. 169-174. 
restrained in trade, but they are bound to do certain acts under a penalty. . . . If nothing in the Act, therefore, will assist the plaintiff, he must still be in a position of a member of an illegal association coming to a Court of justice to assist him to enforce his rights under the illegal association. If that is so, it is impossible for me, and I do not think it even was intended by the Legislature, looking to the terms of the Act, to enable the Courts to interfere on behalf of the members of these societies for the purpose of getting relief inter se with respect to rights and liabilities contrary to the Act. . . ."

The case of Duke v. Littleboy, ${ }^{1}$ it is submitted, Duke v. must now be regarded as of very questionable Littleboy. authority, and should be read in connection with the review of the cases subsequently criticised $(a)$. In it the executive council of a registered trade union, through its officers, claimed an injunction against officers of a branch to restrain them from dividing funds belonging to the central society among members of the branch, and they claimed payment of the balance over after the current expenses of the branch had been satisfied. In so far as section 4 (3) (a) was concerned, the only authority, adduced in the argument or referred to in the judgment, was Rigby v. Connol (b); curiously enough, the Scottish case of M'Laren v. Miller (c), which was identical as to facts, and was contrarily decided, does not appear to have been cited.

Denman, J. followed Rigby v. Connol and adopted Denman, 1 (1880) 49 L. J. Ch. 802.

(a) Infra, pp. 161 et seg.

(b) Supra, p. 131.

(c) Infra, p. 138. 
the reasoning of Jessel, M.R. He observed ${ }^{1}$ : "This application is contended to be not a legal proceeding instituted with the object of directly enforcing an agreement, but it is for an injunction, and it is intended to stop there at present, and to prevent trustees doing what they please with, or returning to members, money in their hands. It appears to me that that is too great a refinement when you look at the true object and at the words of the Act, 'legal proceedings,' which are very elastic. Is not this a proceeding instituted with the object of directly enforcing an agreement for the application of the funds of a trade union to provide benefits for members? What other object has it? It is undoubtedly intended to be followed with something further; it would be useless if it were limited merely to keeping the funds locked up. ... Rigby v. Connol (a) was an application to restore a member. This is to prevent funds from being dealt, with in any other manner except according to the rules, and I think it would be frittering away the meaning of this clause if I were to put any other construction upon it than that this is a proceeding directly to enforce an agreement to apply the funds of a trade union to provide benefits to members ; and that I cannot, without overruling Rigby v. Connol, or putting a forced and untrue construction upon the rules of this society, hold that the plaintiff is entitled to succeed."

Aitkin v. In Aitken v. Associated Carpenters and Joiners of Associated Scotland ${ }^{2}$ a member of an unregistered trade union tersand Joiners of Scotland. 1 (1880) 49 L. J. Ch. 802, at p. 804. $\quad 2$ (1885) 12 R. 1206. 
brought an action against the union concluding (1) for reduction of certain resolutions imposing a fine upon him and depriving him of membership, and (2) for declarator (a) that his expulsion was illegal, and that he was entitled to damages for loss of benefits attached to membership. The First Division (Lord President Inglis, Lords Mure and Shand) unanimously held: (1) That the society being merely a voluntary association no action lay at the instance of a member to enforce his right to membership unless he could show patrimonial loss, and that the only loss alleged was deprivation of a right under a contract not enforceable by law ; and (2) that an action against a trade union directed to enforcing or recovering damages for breach of an agreement to provide benefits could not be entertained by the Court (b).

Lord President Inglis commented on section 4 thus ${ }^{1}$ : "This case is a complaint by a member that Lorrd he was first fined, and then expelled from his union, which, he says, was in violation of the laws of the union. The pursuer seeks to reduce the proceedings by which he was expelled, and to have it found and declared that he was unlawfully and without just cause expelled from, and deprived of, membership of the society, and all the rights and privileges 112 R., at pp. 1211 et seq.

(a) An action for "declarator" is one in which some right of property, servitude or status is sought to be declared in favour of the pursuer, but where nothing is demanded to be performed by the defender. See also p. 174 (a). (b) In this case M'Kernan and Shanks v. United Operative Masons' Association (pp. 128, 130), Rigby v. Connol (p. 131), and McLaren v. Miller (p. 138) were referred to, but not Wolfe v. Mattheus (p. 142). 
attaching to membership. Supposing the pursuer's complaint was made by a member of any other kind of society, and not of this tolerated kind of trade union, the only ground upon which the pursuer could maintain an action of this kind would be that he had suffered patrimonial or pecuniary loss, or that he had been deprived of some civil right $(a)$. Now, so far as I can see, the only patrimonial loss which the pursuer can represent himself as having sustained, and the only civil right which he can say has been invaded, is the loss of the prospect of his being entitled to come upon the funds of this association. ... There is no other right he can derive from being a member of this union. But this is precisely the kind of agreement comprehended by the fourth section of the Act."

Lord Mure

Lord Mure, after stating that the question for decision was whether this was an action which pointed at the recovery of benefit money and was therefore an unenforceable action, came to the conclusion that it was of such a nature. "Of this," he said," "I have no doubt, for the main object of the action, as shewn by the conclusions of the summons and by the averments on the record, is to reduce certain resolutions of the defenders, by which the pursuer alleges that he was deprived of membership in the society, and to have it declared that the pursuer is still a member, and entitled 'to all the rights, benefits, and privileges of membership '-and to compensation for the loss

1 (1885) 12 R. 1206, at p. 1212.

(a) Vide infra, pp, 160-174. 
of benefits of which he had been deprived. 'The pursuer wishes still to participate in the benefits of the society, and it is the defenders' refusal to allow him to do so which is at the root of the action." Lords Shand and Adam concurred.

The case of Chamberlain's Wharf, Limited v. ChamberSmith ${ }^{1}$ must now be regarded with considerable lain's doubt as to whether it is still good law. In view of the fact that it has never been specifically reversed, it will be expedient to review it, and to reserve for a subsequent stage the considerations which render it of doubtful authority $(a)$. The Court of Appeal (Lord Alverstone, M.R., Rigby and Collins, L.JJ.) reversed an interlocutory injunction pronounced by Kekewich J., restraining the defendant association from acting upon a resolution expelling the plaintiff for committing a breach of rules, and held that, the association being illegal, this suit fell within section 4 (1) of the 1871 Act (b), and that the Court had no jurisdiction to entertain it.

Lord Alverstone, M.R., in delivering judgment, Lord observed: "Looking at the substance of the AliRer. matter, I think this action is a proceeding 'instituted with the object of directly enforcing' the agreement contained and embodied in the rules of the association. And in my opinion we could not come to any other conclusion without (I will not say over-ruling) but to a great extent limiting the decision of Jessel, M.R., in Rigby v. Connol (c). Co. Ld. v. Smith.

Alcerstone, ${ }^{1}$ [1900] 2 Ch. 605.

(a) Infra, pp. 153, 161 et seq.

(c) Supra, p. 132.

(b) Sılra, p. 131. 
... It is true that in that case the question arose under sub-section 3 of section 4 of the Act of 1871, but, if I am right in my view of the essence of this agreement, I think the same principle applies to a proceeding to enforce the terms of an agreement which falls within sub-section 1 of section 4."

Collins, Collins, L.J., was of opinion that this case came in terms within the decision of Rigby v. Connol, and adopted the reasoning of Sir George Jessel's judgment therein.

M'Laren v. Miller.

In the Amalgamated Society of Railway Servants for Scotland v. The Motherwell Branch of the Society, otherwise called $M{ }^{\prime}$ Laren $\mathrm{v}$. Miller, ${ }^{1}$ it was held by the Second Division of the Court of Session (Lords Ormidale, Gifford, and Young), that an application, at the instance of the general trustees of a registered trade union for interdict against the trustees of a branch to restrain them from applying funds in their hands for purposes alleged to be other than those specified in the rules, does not fall within the category of legal proceedings instituted with the object of " directly enforcing or recovering damages for the breach of" any of the agreements enumerated under the Trade Union Act, 1871, section 4, and is not therefore a legal proceeding which the Court has no power to entertain. The Court, having found that the defenders proposed illegally to interfere with and appropriate the funds in question, granted interdict restricting them from applying any part of the said funds until the rights of the parties were ascertained. In this case the pursuers petitioned 
for interdict against the defenders (1) uplifting certain sums of money deposited in the bank in their names; (2) paying away any portion of these funds except in accordance with the rules ; (3) carrying out a resolution alleged to have been come to to uplift these funds and pay them away. They contended that a division of the funds in the manner proposed by the defenders was ultra vires and illegal. 'The defenders set up section 4 of the 1871 Act. They further contended that the action was incompetent on the ground that it was virtually an action of declaration affecting the society's organisation and not an action for payment. The basis on which all the judges founded their judgments was that the suit was not a legal proceeding for directly enforcing any agreement or claim for damages, but was a proceeding by interdict to preserve the status quo of the parties.

This decision is the first in which the distinction Meaning has been taken that, in interpreting the meaning of the words " directly enforced" in section 4 there is a of "direct enforcement." difference in granting an interdict or injunction as compared with granting a declarator or declaration. In this case McKernan v. United Operative Masons' Association (a) was referred to, but no reference is to be found in the report to Shanks v. The Same (b), nor to Rigby v. Connol (c). Lord Ormidale explained the differentiation in the following terms ${ }^{1}$ : "The Lord Ormidale. action is one for interdict alone, without any declaratory or petitory conclusions, the object being to

${ }^{1}(1880) 7$ R. 867 , at p. 871.

(a) Supra, pp. 128 et seq.

(b) Supra, p. 130.

(c) Supra, p. 131. 
prevent certain funds from being diverted from their alleged proper uses." His Lordship then adopted the words of the Sheriff-Principal, whose decision, now under review, found that " the present action being one of interdict, does not fall within the category of legal proceedings instituted with the object of directly enforcing or recovering damages for the breach of any of the agrecments enumerated under section 4, and is not therefore an action which the Court has no power to entertain."

His Lordship continued: "The action is simply one for interdict, and that appears to me to contain the essence of this case. Whether in point of law the conclusion to which the sheriff has come, that the fourth section of the statute quoted does not apply, is a right one can only be ascertained by a consideration of that section itself. To my mind it is obvious that the expressions in the section have no reference to actions of interdict, which are intended merely to preserve the status quo. As to whether the expression 'enabled' in the section must be construed to mean that the Court cannot entertain any action in which damages are concluded for, observations were made during the argument to the effect that we were inclined to think that such actions were not necessarily excluded, but only that no aid was to be taken from the statute to make them competent, if in themselves they were incompetent at common law $(a)$. It is, however,

(a) It is obvious that by the has not jurisdiction to entertain words " competent" and "incompetent" his Lordship here means that the Court has or the action, and that the action is therefore enforceable or uncnforceable. 
unnecessary to decide that point in this case, because McKernan's case (a) seems to decide that such an action cannot be sustained. . . . But the judgment referred to is not applicable to this case, which is one for interdict. That being the nature of this case, McKernan's action, which contained a petitory conclusion for money, is of a different character, and has little or no bearing on the present case."

Lord Gifford observed " : "This is not in my view all action to enforce any of the agreements mentioned Lord Gifford. in section 4 of the statute. It is not in the least an attempt to obtain judicial sanction and judicial enforcement contrary to the provisions of the statute. It does not seek to make good by decree anything which the statute declares shall not be so enforced. On the contrary, the action may be defined and described as simply one to prevent a misapplication of trust money belonging to a legal society, and held by them for legal and legitimate trust purposes. If the defendant trustees are about to uplift certain funds in their possession, which are the property of the society, and to apply them to purposes not authorised by the society's rules, a decree to prevent such a proceeding will be quite as competent against these trustees of a trade union society, allowed and recognized by law, as it would be against any private trustee misusing or embezzling private trust funds. . . . I think the interdict must be granted until the rights of the parties are cleared up, the object being merely to preserve the status quo." Lord Young, referring to McKernan's case, said ${ }^{2}$ : Lord

$$
{ }^{1}(1880) 7 \mathrm{R} \text {., at p. } 872 . \quad{ }^{2} \text { Ibid., at p. } 873 .
$$


"I think it right to say that I could only concur in some of the observations of the judges in that case if at common law, and before the statute was passed, the action would not have been maintainable in this Court. . . . All the 1871 Act says is, that having regard to the nature of the agreement sought to be enforced, if it would not have been enforceable at common law, the statute will give no assistance."

Wolfe v. In Wolfe v. Matthews ${ }^{1}$ members of an unregistered Matthews. society sought an injunction to restrain other members from applying any part of the funds of the society in carrying out an amalgamation of the society with another society. Duke v. Littleboy (a) was not cited, the only case referred to (at any rate in the report) being Rigby v. Connol (b). In repelling the preliminary objection to want of jurisdiction $F r y, J . \quad$ in the Court, Fry, J., said ${ }^{2}$ : "It is plain that this is not an action to recover damages for the breach of an agreement, neither is it, in my judgment, an action directly to enforce an agreement, which proceedings are alone mentioned in the fourth section. An order that the defendants should pay money to the plaintiffs would be a direct enforcement of an agreement for the application of the funds, but all that is sought here is to prevent the payment of the moneys to somebody else. Either that is no enforcement of an agreement at all, or it is an indirect enforcement. To take a simple case, if there is a contract by A. to pay $£ 100$ to $\mathrm{B}$., that

' (1882) 21 Ch. D. 194.

2 Ibid., at p. 195.

(a) Supra, p. 133.

(b) Supra, p. 131. 
contract is directly enforced by a judgment of the Court directing A. to pay B. And the contract is only indirectly enforced, or not at all, by a judgment restraining $\mathrm{A}$. from paying the money to some one else. It is only by a stretch of language that such an order can be said to enforce A.'s contract; the utmost that can be said is, that it is then more likely that A. will pay B. For these reasons I am of opinion that the judgment of Jessel, M.R., in Rigby v. Connol does not apply to this case, and that the preliminary objection must be overruled, though it will remain to be seen whether the terms of the Act will eventually permit any relief to be given by the Court to the plaintiffs." It is interesting to observe that Fry, J., had arrived at the same conclusion as the Second Division of the Court of Session in M'Laren v. Miller (a), though that case does not appear to have been cited. While the ground of Fry, J.'s decision seems to have been that the grant of an injunction is either an indirect enforcement or no enforcement of an agreement, the Scottish Court regarded the grant of an injunction (or, rather, interdict) merely as preservative of the status quo. This approaches more closely to no enforcement than to indirect enforcement.

In Yorkshire Miners' Association v. Howden, ${ }^{1}$ the Yorkshire action was brought by the plaintiff, a member of a Mssocia. registered trade union, which, but for the 1871 IIow $\begin{aligned} & \text { tionden. } \\ & \text { Ind }\end{aligned}$ Act, was admitted to be illegal, against that union and its officers for the purpose of restraining them

$$
\frac{{ }^{1}[1905] \text { A. C. } 256 .}{\text { (a) Supra, p. } 138 .}
$$


by injunction from misapplying the funds of the association contrary to its rules and the provisions contained therein. It was held unanimously in the Court of Appeal ${ }^{1}$ and affirmed by the House of Lords (Lords Davey and James dissenting) (1) that the action was not instituted with the object of "directly enforcing" an agreement for the application of the funds to provide benefits to members within the meaning of the Trade Union Act, 1871, section 4 , the object being not to enforce application, but to prevent misapplication, of the funds, and that the action was consequently maintainable; and (2) that the payment of strike pay made in pursuance of a resolution of the executive council of the defendant association was in contravention of the rules, and that the resolution purporting to authorise such payment was ultra vires and illegal $(a)$.

In the Court of Appeal, Vaughan Williams, L.J., distinguished this case and the case of Wolfe $\mathrm{v}$. Matthews (b) from Rigby v. Connol (c) on the ground that in the latter case the plaintiff, who had been

Court of Appeal.

Vaughan Williams, L.J. expelled from a trade union, was claiming to be entitled to participate in the benefits of the union, and was asking for an injunction restraining the defendants from excluding him. His Lordship

$$
{ }^{1} \text { [1903] } 1 \text { K. B. } 308 .
$$

(a) But in Mullet v. United French Polishers' Society, (1905) 91 L. T. 133, Kekewich, J., declined to entertain an action claiming a declaration that a fine was ultra vires and illegal on the ground that the case fell within Rigby v. Connol, and that Howden's case had no application to it.

(b) Supra, p. 142.

(c) Supra, p. 131. 
made the same observation in regard to Chamberlain's Wharf, Ltd. v. Smith (a). Stirling, L.J., observed ${ }^{1}$ : Stirling, "By s. 4, sub-sec. 3 of the Trade Union Act, 1871, the Court is prohibited from entertaining any legal proceeding instituted with the object of directly enforcing or recovering damages for the breach of any agreement for the application of the funds of a trade union, not generally, but in three specified cases. The objects of a trade union may, and in the present case do, include others than those mentioned in this section $(b)$; and the Act contains nothing to prevent the Court from entertaining a legal proceeding for the purpose of enforcing agreements with respect to those of other objects. 'The section clearly cannot be read as prohibiting the Courts from entertaining proceedings for enforcing every agreement with reference to the funds of trade unions. It is said, however, that the present action falls within a prohibited class, namely, the class of actions which are brought with the object of directly enforcing an agreement for the application of the funds to provide benefits to the members. In my opinion it does not. The word "directly" is important, and ought to have effect given to it. If, for example, the object of the action were to establish the plaintiff's title to a benefit or benefits provided for members of the association, then it would fall within the prohibition, as has been decided in Rigby v. Connol (c) and Chamberlain's

\section{1 [1903] 1 K. B. at p. 337.}

(a) Supra, p. $137 . \quad$ (b) Supra, p. 28.

(c) Supra, p. 131.

T.U. 
Wharf, Ltd. v. Smith $(a)$ : a fortiori if the action claimed any such benefit for the plaintiff individually. . . . But no application of the funds in favour of the plaintiff is claimed by the action. All that is sought is that the funds shall not be dealt with otherwise than in accordance with the rules. . . . It is truly said that the result will be that, if the plaintiff ever becomes entitled to any benefit under the rules, there will be funds available for that purpose which would otherwise have disappeared; but in my opinion the object of the action is not directly to enforce any agreement to provide a benefit for him, but at most only to do so indirectly."

Matthew, Matthew, L.J., said ${ }^{1}$ : "It is argued for the plaintiff that this is merely an application for the purpose of protecting the funds of the association, and compelling the trustees to do their duty and maintain the status quo; that it is not an application for the benefit of the plaintiff, who will remain, after the injunction is granted, in precisely the same position as before; and the action is therefore not one prohibited by the section. It is said on the other side that there are authorities which dispose of the case in favour of the defendants. Two decisions were cited, which are no doubt authorities entitled to the highest respect, namely, that of Jessel, M.R., in Rigby v. Connol (b) and that of the Court of Appeal in Chamberlain's Wharf, $L t d$. v. Smith $(a)$. Those cases are in my opinion clearly distinguishable from the present case. In ${ }^{1}$ [1903] 1 K. B. at p. 348.
(a) Supra, p. 137.
(b) Supra, p. 131. 
each of them the action was brought to prevent the expulsion of the plaintiff from a society. It cannot be doubted that the object of the plaintiff in each of those cases was to secure for himself the benefits of the association. He was not representing the interest of anyone else in the action. It was therefore held that the ease came within the spirit and also the letter of the Act. Then we have the decision of Fry, J., in Wolfe v. Matthews (a) and that of the Scottish Court in M'Laren v. Miller (b), which, no doubt, is not binding on us, but is a valuable statement of judicial opinion, to the effect that such an action as that in the present case is maintainable. I think these decisions are in point."

In the House of Lords, ${ }^{1}$ the Lord Chancellor, Earl of Halsbury, in his judgment ${ }^{2}$ adopted the reasoning of Fry, J. in Wolfe v. Matthews and quoted the following passage :- "An order that

House of Lords. Lord Halsbury, L.C. the defendant should pay money to the plaintiff would be a direct enforcement of the agreement for the application of the funds, but all that is sought here is to prevent the payment of the money to someone else. Either that is no enforcement of an agreement at all or it is an indirect enforcement." Lord Halsbury observed: "I cannot escape from this reasoning, nor do I see any inconsistency between that decision and the case of Rigby $\mathbf{v}$. Connol (c) before Sir George Jessel, and a long line of judicial decisions has recognized the distinction

${ }^{1}$ [1905] A. C. 256.

${ }^{2}$ I bid., at p. 261.

(a) Supra, p. 142.

(b) Supra, p. 138.

(c) Supra, p. 131. 
which the learned Judge himself pointed out between the case before him and the decision given by Sir George Jessel. I am bound, however, to say that, if that decision ever came up for review, I think it would have to be considered whether it does not strike the word 'directly' out of the statute."

Lord Lord Macnaghten expounded the meaning of the Macnaghten. word "directly" thus ${ }^{1}$ : "I cannot think that the Legislature intended to strike at proceedings for directly enforcing certain agreements, leaving untouched and unaffected all proceedings (other than actions for damages) designed to enforce those particular agreements indirectly. 'To forbid direct action in language that suggests that the object of the action so forbidden may be attained by a sidewind seems to me somewhat of a novelty in legislation. I venture to think that the word 'directly' is only put in to give point to the antithesis between proceedings to enforce agreements directly and proceedings to recover damages for breach of contract, which tend, though indirectly, to give force and strength to the agreement for breach of which an action may be brought. Speaking of section 4 generally Lord Macnaghten observed" : "What was the object of the present litigation? Was it to enforce an agreement for the application of the funds of the union to provide benefits to members? I should say certainly not. The object of the litigation was to obtain an authoritative decision that the action of the union, which was challenged by the plaintiff, was not authorised by the rules.
1 [1905] A. C., at p. 264.
${ }^{2}$ Ibid., at p. 265. 
The decision might take the form of a declaration or the form of an injunction, or both combined. No administration or application of the funds was sought or desired. The object of the litigation was simply to prevent misapplication of the funds of the union, not to administer those funds, or to apply them for the purpose of providing benefits to members. I am aware that in expressing this view I am dissenting from the opinion of Sir George Jessel in the case of Rigby v. Connol (a). . . . The proceedings which the plaintiff has instituted do not, I think, involve the administration of the funds of the association, collected for benevolent purposes, or the application of those funds to provide benefits to members. Nor was the litigation, as it seems to me, instituted with that object. It was simply an application to the Court to determine the true construction of certain rules which had been, as the plaintiff contended, misconstrued by the executive of the association."

Lord Lindley in his judgment gives a concise classification of the effects of section 4." "'The words Lord Limlley. of section 4," he said, "suggest the following observations: (1) The section extends not only to Courts of law, but also to Courts of equity.

(2) The section does not prohibit any Court from exercising in any case jurisdiction which it could have exercised before the Act passed ; the section simply prevents any Court from extending its jurisdiction, and interfering in cases in which the Act would ${ }^{1}$ [1905] A. C. at pp. 281 et stq.

(a) Sinpra, p. 131. 
authorise interference if it were not for the direct prohibition contained in the section. (3) No legal proceeding, which might be taken, if the section did not prohibit it, is prohibited, except a legal proceeding instituted with the object of directly enforcing or recovering damages for the breach of the specified agreements. The word 'directly' is important and limits the application of the section. Legal proceedings for other purposes than those specified are not prohibited ; although they may indirectly affect agreements on which noaction can be brought."

Lord lindley remarked that the only agreement to be considered was the third one in section 4, viz., an agreement for the application of the funds of a trade union (a) to provide benefits to members, or (b) to furnish contributions, or (c) to discharge any fine. "I am," he continued, "quite unable to see that these words include such an action as that which has been brought in this case. ${ }^{1}$ 'The object of this action is not directly to enforce any agreement for the application of the funds of the trade union in any of the ways specified under the third head. The object of the action is not to apply the funds, but to preserve them for future application; and to my mind this action is no more struck at by s. 4 than is an action brought by the trustees for the recovery of the funds of the trade union from some person wrongfully in possession of them." 2 His Lordship was of opinion that the object of this action was not to enforce a contract between the plaintiff and the defendants, nor to distribute
${ }^{1}$ [1905] A. C. at p. 282.
${ }^{2}$ lbid., at p. 281; infra, p. 174. 
funds held in trust for the members of the union nor to obtain payment of any money out of the funds, nor in any way to administer them, but that its object was to vindicate a right to property by means of an injunction restraining the intended misapplication of the funds. "All trusts," he said, " except those created by statute or by will may be said to be created by a contract between the parties to the instrument creating the trusts. But these trusts can be enforced in equity by any person entitled to the benefit of them. A suit by a cestui que trust against his trustee is not what is usually understood as a proceeding to enforce an agreement ; if it were, the suit could only be maintained by some person who was a party to the agreement creating the trust. Considering the object of the action, it appears to me competent for any member who has a beneficial interest in the funds of the union to sue to prevent their application to purposes not warranted by the rules as they stand. It is true the rules may be altered, but it does not follow that the Court ought not to enforce the trust created by them as they stand." 1

Lords Davey and James dissented on the ground that in their opinion this action was brought for Lord James. the purpose of "directly" enforcing an agreement for the application of the funds of a trade union to provide benefits to members, and that there was no distinction in principle between an injunction to restrain the exclusion of the plaintiff from a right to participation in the property, and one to restrain

${ }^{1}$ [1905] A. C., at pp. 230 et seq. 
the removal or diversion of the property in which he claims to participate. Referring to the case of Lord M'Laren v. Miller (a), Lord Davey remarked ${ }^{1}$ : Darey. "The interdict granted there was only to keep things in statu quo until the rights of the parties should be ascertained. It was, however, an action, by trustees under s. 9, to which, I think, different considerations may apply $(b)$. If and so far as it is a decision against the opinion I have already expressed on the construction of the Act, I think it was wrongly decided."

Steele v. The decision in Steele v. South Wales Miners' South

Wales

Miners'

Federa-

tion.

Federation ${ }^{2}$ rested partially on the ground that the definition of the term "trade union" in section 16 of the 1876 Act was not exhaustive and therefore did not precludeParliamentary representation from being one of the purposes of a trade union $(c)$; partially on the ground that the Court, on the authority of Macdougall v. Gardiner, ${ }^{3}$ declined to interfere in what was merely a matter of internal administration Philli of the federation. Mr. Justice Phillimore, however, more, $J$. was of opinion that an injunction, restraining the levy of funds for Parliamentary representation, would not be a direct enforcement of an agreement providing benefits to members. He observed ${ }^{4}$ : "No doubt the decisions in Rigby v. Connol and Chamberlain's Wharf, Ltd. v. Smith warrant the

1 [1905] A. C., at p. 274.

${ }^{2}$ [1907] 1 K. B. 361 .
3 (1876) 1 Ch. D. 13.

$4[1907] 1$ K. B. at p. 370. (a) Supra, p. 138.

(b) Infra, p. 174.

(c) But see Amalgamated
Society of Railway Servants v. Osborne (No. 1), [1910] A. O.87 ;

Chapter II., p. 27. 
contrary contention, and as the latter is a decision of the Court of Appeal, if it stands it is binding on us. But after the decision in Howilen v. Yorkshire Miner's' Association in the House of Lords, I think it is very difficult now to regard Chamberlain's Wharf, Ltd. v. Smith as being good law. In Howden's Case the plaintiff was allowed, in virtue of his proprietary interest in the funds of the union, to maintain an action to prevent their diversion to an unauthorised purpose. But if a member can get an injunction to prevent their going to an unathorised person (quaere, 'purpose'), surely he may equally get an injunction to prevent his being excluded from all share in the benefit of them, and that is what would ultimately be the result of the proposed levies, if permitted to be made." I)arling, J., expressed no opinion on this subject, and the refusal to grant the injunction craved for by the plaintiff was based by both judges on the other grounds already referred to.

In Cope v. Crossingham ${ }^{1}$ the plaintiffs, the head trustees of a registered trade union, admittedly Cope v. C'rossingillegal apart from the 1871 Act, brought an action against the trustees of a branch, claiming (1) a declaration that a resolution, providing for secession and for distribution of the funds in its possession, was ultra vires of the branch; (2) an injunction restraining the trustees of the branch from dealing with the funds otherwise than in accordance with the society's rules; (3) the removal of the trustees of the branch and the appointment of new trustees; and (4) administration by the Court of the funds ${ }^{1}$ [1909] 2 Ch. 148. 
and property of the branch. It was unanimously held by the Court of Appeal (Cozens-Hardy, M.R., Buckley and Kennedy, L.JJ.), affirming Eve, J., (1) that under the rules the plaintiffs had a sufficient interest in the property of the branch to maintain the action $(a)$; $(2)$ that the intended distribution was ultra vires the rules; and (3) that the action, apart from the claim for administration, was not instituted with the object of directly enforcing an agreement within the meaning of section 4 of the 1871 Act; but it was held (4) that the Court had no jurisdiction to make any order for payment, which would be an administration of the funds, though it would, if necessary, grant an injunction.

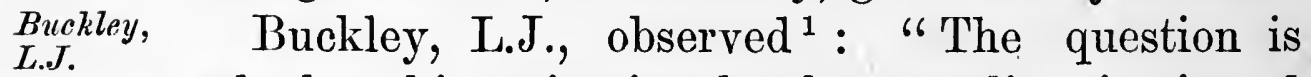
whether this action is a legal proceeding instituted with the object of directly enforcing an agreement for the application of the funds of the union to provide benefits to members. I do not address myself particularly to the word ' directly.' It may well be that that word means (by way of contrast) enforcing by direct order as distinguished from enforcing by the recovery of damages for breach. This action is not, 1 think (within any meaning of the word 'directly'), such a legal proceeding as is excluded by section 4.... In this action the Court has nothing to do with the right of any member to a distributive share of the fund. All the Court is asked to do is to see that the fund is preserved, leaving its proper destination as between 1 [1909] 2 Ch., at pp. 159 et seq.

(a) Infra, pp. 169-174, and 176. 
the members entitled to share in the fund wholly unaffected by any judgment which the Court is asked to pronounce." His Lordship thought that the present case was governed by Wolfe v. Matthews and Yorkshire Miners' Association v. Howden (a).

Kennedy, L.J., after referring to the ambiguity of the language of section 4, which had led to Kennedy, L.J. the remarkable divergence of judicial interpretation in Yorkshire Miners' Association v. Howden, observed ${ }^{1}$ : "The defendant trustees have threatened to obey the resolution of the branch by distributing the funds in question amongst members of the branch, not as 'benefits' under the rules at all, or for any purpose named or contemplated in the rules, but substantially as gifts to those members. In my view this would be a dealing with the trust funds ultra vires; and the present action, so far as the prayer for a declaration and for an injunction is concerned, is a legal proceeding to declare that such a dissipation of the funds, collected from the group of members forming this branch and held by the defendant trustees for the objects of the association, is ultra vires, and to prevent it by an injunction." His Lordship thought that this action was on all fours with McLaren v. Miller (b), and was governed by the decision in Howden's Case.

In Osborne v. Amalgamated Society of Railway Servants (No. 2) ${ }^{2}$ a member of a registered trade union, who had been expelled by a resolution of the ${ }^{1}[1909] 2$ Ch., at pp. $167 \quad{ }^{2}[1911] 1$ Ch. 540, and vide
et seq.

Osborne v. Amalgamated Sirciety of Railway Servants (No. 2).

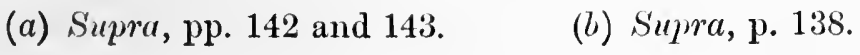


executive committee, brought an action to obtain reinstatement on the ground that the resolution of expulsion was ultra vires and void, and he claimed an injunction restraining the defendants, their officers, agents, or servants from acting upon or enforcing the resolution or such part of it as referred to his expulsion. It was held unanimously by the Court of Appeal (Cozens-Hardy, M.R., Fletcher Moulton and Buckley, L.JJ.), reversing Warrington, J., that the action was not a proceeding instituted with the object of directly enforcing an agreement for the application of the funds of the union "to provide benefits to members," and that the action was therefore maintainable.

CozensHardy, M.R.

Cozens-Hardy, M.R., observed ${ }^{1}$ that the contention of the defendants involved two propositions -(1) That the society is at common law an unlawful association (a); and (2) that this action is a legal proceeding which no Court can entertain, having regard to section 4 of the Act of 1871: and that, if either of these propositions was not well founded, the defendants must fail.

His Lordship thought that the present action was not a legal proceeding "instituted with the object of directly enforcing or recovering damages for the breach" of an "agreement for the application of the funds of the trade union to provide benefits" to the plaintiff. Payment of any sum of money out of the funds of the union was not claimed. If the plaintiff obtained the declaration and injunction

${ }^{1}$ [1911] 1 Ch., at pp. 551 and 554 et seq.

(a) supra, p. 118. 
applied for, he would be entitled, not as a matter of legally enforceable right, but as a matter of reasonable expectation, to certain benefits for which he had subscribed. If a member was threatened with expulsion on grounds not justified by the rules, there was nothing in section 4 which prevented him from maintaining an action to restrain the contemplated wrong. The language of section 4 was narrow, and ought not to be construed so as to cover every arreement under section 3. The plaintiff had in the funds of the society an interest which, in the event of a dissolution, might be asserted in a Court of justice. ${ }^{1}$ He had rights of voting under the rules, and a right of voting was a property right.

Fletcher Moulton, L.J., observed" "The only disabilities under which a trade union or its members Fletcher Moulton, lie, relate to the enforcement of contracts and not L.J. to their validity. In the present case we have to assume, for the purposes of this argument, that the plaintiff lawfully became and continued to be a member of the trade union, and that he has been wrongfully expelled therefrom. If this had not been a trade union, but some society whose lawfulness did not depend on the Act of 1871, no one could have seriously contended that the Courts could not entertain his claim for reinstatement into his former position of membership. Now trade unions and their members are in as good a position

1 In re Printers' and Transferrers' Amalgamated 'Trades Protection Suciety, [1899] 2 Ch.
187.

2 [1911] 1 Ch, at pp, 557 et seq. 
in all respects as other societies and their members, except as regards the enforcement of contracts, and there only if the contract which is sought to be enforced comes within one of the excepted classes. The contract of membership is the contract which the plaintiff secks here to enforce. He says that he has been admitted to membership and has performed all conditions for his continuance therein. This is not denied for the purposes of to-day. But the defendants say that this demand for reinstatement is a legal proceeding instituted with the object of directly enforcing an agreement for the application of the funds of the trade union to provide benefits for members. To test this, let us assume that the relief is granted and that the

Effect of declaration. plaintiff is declared a member of the trade union. Will the effect of that be to enforce an agreement for the application of the funds of the trade union to provide benefits for him? The only possible answer to this question is, Certainly not. By the statute that is the very thing which his membership does not entitle a man to do, and therefore declaring him a member simpliciter not only does not directly enforce the application of funds for his benefit, but does not even help him in any future proceeding to enforce any such agreement. It seems to me to be a logical contradiction to say that to put a man in a position where he cannot enforce a particular agreement is enforcing it. All that the Court is asked to do here is to declare that the plaintiff is entitled to the performance of the agreement to accept and to keep him as member, 
and inasmuch as this is not in itself an application of the funds of the trade union to provide benefits for a member, and does not even enable the plaintiff by subsequent proceedings to enforce any agreement so to apply them, the subject-matter of this action appears to me to be entirely outside the excepted classes enumerated in section 4."

Fletcher Moulton, L.J., concluded: "If the law status. is prepared to defend personal rights it must possess the power of deciding who possesses them. Further, a suit to defend the property of the society can certainly be brought by the society itself since the Act of 1871. 'To enable this to be done was one of the main objects of that Act (a). In such a suit the Courts must of necessity decide whether the plaintiff has the right to call itself the society $(b)$. This may well depend on decisions as to membership. . . . In a suit purporting to be in the name of the society the Court must decide whether the plaintiffs are entitled to use its name, and this must entail in such a case an examination as to the legality of the acts and their legal effect on membership. Otherwise the rights of members would be at the mercy of those who most persistently pursued illegal courses. When the Legislature legalised the status and contracts of trade unions, it was to save them from such chaos as this, and if the limitations to the action of the Courts contained in section 4 be closely looked at, it will be found that they leave untouched the
(a) Supra, pp. 12 et seq.
(b) Infra, pp. 174 et seq. 
jurisdiction of the Courts to pronounce on the meaning or validity of any contract whatever."

Buckley, Lord Justice Buckley observed ${ }^{1}$ that the joint
L.J. effect of sections 3 and 4 of the 1871 Act was to render lawful the contract of co-membership in a trade union even if it had purposes in restraint of trade, but to render certain of the mutual relations unenforceable. He said" : The plaintiff was a person who before his expulsion enjoyed certain contractual relations with the other members of the defendant society, which even if the trade union was illegal at common law was by s. 3 lawful as a matter of contract between him and his co-members. He enjoyed a vote as a member; a right to subscribe to certain funds, a right to benefits from those funds, an interest in common with his fellow members in the property of the society, a like right in all the advantages of membership, and, in case the society should be dissolved and the common purposes thus come to an end, a right to his distributive share of the assets. These rights, were all, by virtue of s. 3, lawful, although some, but not all, were, by virtue of s. 4, unenforceable. The right to have benefits from the funds was unenforceable; others seem to me clearly to be enforceable. There is nothing in s. 4 to forbid a Court to entertain legal proceedings to enforce the member's right to his vote or his right to his distributive share in winding up. It is quite plain that he had rights in respect of property. 
All the property of the society belonged to him and his co-members, and none the less because s. 4 renders unenforceable certain rights in respect of that property. His vote was property ${ }^{1}$. . . B But it is said that an order to declare his expulsion ultra vires, and a proper consequential injunction will be an enforcement of the agreement in the rules to apply the funds to provide him with benefits. I cannot follow the contention. How can an order to restore him to membership do more than make him what he was before, namely, a member with the same unenforceable rights? How does such an order enforce those rights. What benefit in the application of the funds is it that the order compels the society to give him? Obviously none. If he succeeds in the action he merely resumes the position in which he stood before. His rights by way of benefit are neither greater nor less than before his expulsion. The whole answer to the contention on this part of this case may be summarised in a sentence. An order to restore membership with unenforceable rights is no order to enforce those rights.

\section{Authorities Reviewed.}

It will be appreciated that, as was foreshadowed at the commencement of this chapter, the interpretation of section 4 has placed the law it enacts in Irreconcilability of authoreties. a state of indecision. Whether, in the words of Lord Macnaghten, "the difficulty is not so much in the language of the Act as in the language of

${ }^{1}$ Pender v. Lushington, (1877) 6 Ch. D. 70.

T.U. 
the learned judges who have expounded it," ${ }^{1}$ and " the commentaries are in fault rather than the text," 1 must remain matters of opinion. There Interpre- can be no doubt that the word "directly" in the "directly," passage-_" no legal proceedings instituted with the object of directly enforcing . . . any of the (specified) agreements will be entertained by any Court"legitimately gives rise to speculative interpretation. The Courts are entitled to assume that every section of an Act of Parliament has a meaning, and it rests with the Courts to interpret what that meaning is from the words of the statute itself, and they will naturally construe an Act in such a way as not to render it absurd. ${ }^{2}$ Bearing this in mind the word " directly" raises two distinct difficulties :

(1) Is it meaningless; and

(2) If not, what meaning have the Courts applied to it?

as meaningless,
(1) Confining attention to the first difficulty, the dictum of Lord Halsbury in Howden s Case bears considerable significance. He observed that there was no inconsistency between Wolfe v. Matthews ( $a$ ) and Rigby v. Connol(b), but added : "I am bound to say that if the judgment of Sir George Jessel in Rigby v. Connol ever came up for review, I think it would have to be considered whether it
1 Yorkshire Miners' Association
v. Howden, [1905] A. C. 256, at
11 App. Cas. 627.
p. 263.
3 Yorkshire Miners' Association v. Houvden, [1905] A. C. 256, 2 Salmon v. Duncombe, (18s6) at p. 261.
(a) Supra, p. 142.
(b) Supra, p. 131. 
does not strike the word 'directly' out of the statute." The inference to be deduced from this dictum is that Sir George Jessel regarded the word "directly" as being meaningless.

(2) In considering those cases in which the judges have applied a meaning to the word as creating all anti"directly," it will be observed that a distinction has been made between actions whose object has been to preserve and prevent misapplication of the funds of the union, but not to administer them, and actions whose object the Courts have held to involve administration of the funds. In other words, an action to enforce negatively by preventing misapplication of the funds is distinguished from an action to enforce directly. ${ }^{1}$ Thus Rigby v. Review of Connol (a) and Chamberlain's Wharf, Ltd. v. Smith (b) $\begin{gathered}\text { authori- } \\ \text { ties }\end{gathered}$ and the like cases have been distinguished from M'Laren v. Miller (c), Wolfe v. Matthews (d), Yorkshire Miners' Association v. Howden (e), and their successors on the ground that the claim in the former actions amounted to a claim directly to enforce participation in the benefits and an injunction restraining exclusion from such participation, whereas the claim in the latter actions amounted merely to a claim indirectly to enforce or not to enforce at all, or to a claim preservative of the status quo. Had the distinction conclusively ended

${ }^{1}$ Cope v. Crossingham, [1909] 2 Ch. 148; per Buckley, L.J., at p. 160.

(a) Supra, p. 131.

(c) Supra, p. 138.

(b) Supra, p. 137.

(d) Supra, p. 142.

(e) Supra, p. 143. 
here it would, at any rate, have been a comprehensible one.

Conflict of But a perusal of the foregoing cases points to authorities.

the conclusion that it is difficult to reconcile them with each other, and consequently not easy to discover the fundamental principle upon which the law in regard to them is based. The resulting confusion is enhanced by the fact that not only have the decisions in Rigby v. Connol (a), Chamberlain's Wharf, Ltd. v. Smith (b), Duke v. Littleboy (c), and other similar decisions, never been reversed, but the Courts have frequently asseverated their soundness.

Partial

Two lines of thought have still further comsoundness of Rigly v. Connol. plicated the question. One line, while specifically asserting the soundness of the actual result in Pigby v. Connol (a), in fact reverses the judgment in that case on the ground that it is too wide. 'The

Complete soundness of Rigby v. Connol.

Modification of judgment in Kigby v. Connol. other line of thought, while asserting the soundness of both the actual result and the grounds of that judgment, differentiates contrarily-decided cases as being distinguishable from Rigby v. Connol (a), thereby rendering it inapplicable to them. The judges, who have pursued the former line of thought, have shown a tendency to modify considerably the scope of the judgment in Rigby $\mathrm{v}$. Connol (a). For instance, Lord Macnaghten ${ }^{1}$ thought that the effect of Sir George Jessel's observations, in conjunction with the cases of unenforceable

'In Yorkshive Miners' Association v. Howden, [1905] A. C. 256, at pp. 265 et seq.
(a) Supra, p. 131.
(b) Supra, p. $13 \%$.

(c) Supra, p. 133. 
contracts specified in the Act, made trade union agreements one and all alike unenforceable; at the same time his Lordship did not wish to be understood as expressing any doubt as to the correctness of the actual decision $(a)$. Lord Lindley ${ }^{1}$ observed that the decision in Wolfe v. Matthews (b) had never been reversed, and he expressed his approval of the decision in ML Laren v. Miller (c). $\mathrm{He}$ thought that those decisions were not in conflict with any other decision, unless it were the action of Duke v. Littleboy $(d)$, the object of which he regarded as wider than that of Wolfe $\mathrm{v}$. Matthews (b) or that of Howden's case (e). Fletcher Moulton and Buckley, L.JJ., thought that the explanation of the decision in Rigby v. Connol $(f)$ Qualified dissent from Rigby v. was to be found in the nature of the relief claimed. They were of opinion that, had the plaintiff's claim been limited to restoration of membership, a different decision might have been arrived at. But, if the judgment implied that an order to restore membership amounted to a specific enforcement of the whole contract of membership, or to a declaration of a right to participation in the benefits and an injunction to restrain prevention of participation, they dissented from it.

${ }^{1}$ [190う] A. C. 256, at pp. 231 et seq.

2 Osborne v. Amalgamated Society of Railway Servants

(a) This view was likewise expressed by Cozens-Hardy, M.R., in Osborne v. Amalgamated Society of Railway Servants (No. 2), [1911] 1 Ch. 540, at pp. 554 and 555 .
(No. 2), [1911] 1 Ch. 540, at pp. 561 and 562 ; and at pp. 568 and 569 , respectively.

\section{Connol.}
(b) Supra, p. 142.
(c) Supra, p. 138.
(d) Supra, p. 133.
(e) Supra, p. 143.
(f) Supra, p. 131. 
Effect of claim involving investiga. tion of rules.

Rule in Rigby v. Connol,

in Chamberlain's Wharf,

Ld. v. Smith, in Oshorne v. Amalgamated Society of Railway Servants (No. 2).

A new feature of some significance has been introduced by Lord Justice Buckley ${ }^{1}$ in support of the soundness of Rigby v. Connol (a). He thought that the restoration of the plaintiff to membership would have involved an investigation of the ground of his expulsion, and that would have involved the question of the validity of the rule for breach of which he was expelled. The same reasoning applied to Chamberlain's Wharf, Itt. v. Smith but was inapplicable to the case of Osborne (No. 2), because the plaintiff in the latter was not expelled for breach of any rule covered by any of the provisions of section 4 . He pointed out that in Chamberlain's Wharf, Ltd. v. Smith (b) the rule for breach of which the plaintiffs were expelled was one providing for "an agreement concerning the conditions on which any members - . shall sell their goods" $(c)$. To adjudicate in the action would, in his opinion, have involved an investigation whether the plaintiffs had or had not broken this rule. "The action," he said, "was to enforce that agreement not affirmatively by restraining members from breaking it, but negatively by restraining the society from expelling members for a breach of it, which the society alleged and they denied." It is, however, somewhat difficult to comprehend why this course of reasoning should not apply to the case of Osborne (No. 2), where the rule was as follows: ${ }^{2}$

1 [1911] 1 Ch. 540, at pp. 569 and $570 .{ }^{2}$ Ibid., at p. 543.
(a) Supra, p. 131.
(b) Supra, p. 137.

(c) Section 4, sub-section 1. 
"Any member found guilty of attempting to injure the society, or to break it up otherwise than as allowed by these rules... the committee shall expel him from the society and he shall forfeit all claims on the funds and benefits of the society." It is submitted that adjudication in the latter case would have "involved an investigation whether the plaintiff had broken" this rule or not. 


\section{CHAPTER VI.}

\section{PROCEDURE.}

Status.

A TRADE union occupies an anomalous position in the law. It is neither a corporation, nor an individual, nor a partnership between a number of individuals. ${ }^{1}$ No change was introduced into its constitution by the Act of 1871 . It remains a voluntary association of which the law can take no special cognizance as a collective body, ... the object apparently being to make careful provision that it should not have any corporate existence or capacity whatever. ${ }^{2}$ Nevertheless, although the intention of the Act of 1871 was to avoid incorporation and the attendant consequences, the Legislature in giving a trade union the capacity to own property and the capacity to act by agents has, without incorporating it, given it some of the essential qualities of a corporation $(a)$. Thus it can act by its agents, and in this resembles such bodies as unincorporated improvement commissioners, established by Act of Parliament. ${ }^{3}$

1 Per Farwell, J., in Taff Vale Railway v. Amalgamated Society of Railway Servants, [1901] 1 K. B. 170. In re Amos, Carrier v. Price, [1891] 3 Ch. 159. ${ }^{2}$ Per Lord Inglis in Aitken v.
Associated Carpenters and Joiners of Scotland, (1885) 12 R. 1206.

3 Per Farwell, J., in Taff Vale Railway v. Amalgamated Society of Railway Servants, [1901] A. C. 426, at p. 432.

(a) Supra, pp. 8-20, 
The 187.1 Act is, as it were, the charter of incorporation, ${ }^{1}$ for thereby trade unions obtain their statutory immunities and privileges, ${ }^{2}$ and in respect of this dependence upon statute, trade unions are in the same position as all corporations, municipal or commercial, including in the latter all limited liability companies created under the Companies Acts. ${ }^{3}$ A trade union, then, at any rate when registered, is a "legal entity, and though not perhaps in a strict sense a corporation, it is a newly created corporate body, created by statute," 4 "... anomalous in that, although consisting of a fluctuating body of individuals and not being incorporated it can own property and act by agents." ${ }_{5}$ On the other hand, an unregistered trade union has apparently no such corporate existence. ${ }^{6}$

\section{Civil Procedure.}

With regard to civil procedure, a trade union, Basis of notwithstanding its quasi-corporate character, is a voluntary association. It is therefore of importance Court's jurisdicat the outset to determine whether the Court has jurisdiction to interfere in the relationship of members of a voluntary association at all, and if so, on what principle.

With the personal relationship of members of

1 Per Earl of Halsbury, in Amalyamated Society of Railway Servants v. Osborne (No. 1), [1910] A. C. 87, at p. 92.

2 Per Lord Macnaghten, ibid., at p. 94.

3 Per Lord Atkinson, ibid., at p. 104 ,
4 Per Lord Brampton, [1901]

A. C. 426, at p. 440 .

5 Per Farwell, L.J., [1909] 1 Ch. 163, at p. 191.

6 Wilson v. Scottish Typo. graphical Association, (1911) 1 S.. L. J. 253. tion. 
voluntary associations, or with their domestic relations in general, the Court declines to interfere. It will be found that the basis of the Court's jurisdiction in interfering with voluntary associations rests firstly, on the right of property vested in the member requesting the Court's interference $(a)$; or secondly, on the existence of a civil right of which such member avers that he has been deprived $(a)$.

Proprie- $\quad$ On the first right of jurisdiction, that of property, Jessel, M.R., said, "The foundation of the jurisdiction is the right of property vested in the member of a voluntary association, and of which he is unjustly deprived $(a)$. . . . There is no jurisdiction to decide upon the rights of persons to associate together when the association possesses no property. Persons, and many persons, do associate together without any property in common at all. . . . But if the association has no property, and takes no subscriptions from its members, I cannot imagine that any Court could interfere with such an association if some of the members declined to associate with some others. The Courts, as such, have never dreamt of enforcing agreements strictly personal in their nature. . . . If property is the foundation of the jurisdiction, the plaintiff, if he can succeed at all, must succeed on the ground that some right of property to which he is entitled has been taken away from him." 1

1 Per Jessel, M.R., in Rigby v. Connol, (1880) 14 Ch. D. 482, at p. 487.

(a) The Court may interfere, by injunction, to restrain an act, on the ground that it tends to the deterioration of property. Springhead Spinning Company v. Riley, (1868) 6 Eq. 551. 
The second right of jurisdiction, that of civil right, is commented on by Lord Justice Fletcher Moulton, as follows ${ }^{1}$ : "There are many rights which could not be called rights of property, which, nevertheless, the law will protect, as, for instance, if there was an association of men subscribing for a benevolent purpose, say for the endowment of a scientific institution, the whole funds of the association being dedicated to that charitable purpose on the terms that the administration should be under the control of the association, I can see no reason why membership of such an association should not have the same legal protection as would be given in the case of an association where the members had a beneficial interest in the funds. In the case of a trade union there is undoubted interest in property even in the narrow sense of the word. The funds of the union belong to the members, and are, by reason of agreement and trusts, which are valid in law, appropriated to the purposes of the trade union, and more especially to giving benefits to members. Should the trade union be dissolved these funds would be divided amongst its members. While it is in existence these members are eligible, and are the only persons who are eligible, to receive the benefits which by its rules follow from membership. They have the right to come to the Courts to protect the misapplication of those funds. It is true that they cannot enforce the application of the

1 In Osborne v. Amalyamated Society of Railway Servants (No. 2), [1911] 1 Ch. 540 ; at p. 562. 
funds to the granting of those benefits, but that is a defect in their remedies and not in their rights" $(a)$.

Basis of jurisdiction in Scotland.

That the law of Scotland rests on a similar basis appears from the case of Aitken v. Associated Carpenters and Joiners of Scotland, ${ }^{1}$ in which Lord President Inglis remarked: "The only ground upon which a member could maintain an action against a voluntary association of this kind would be that he had suffered patrimonial or pecuniary loss, or that he had been deprived of some civil right." In the same case, the principles were more elaborately illustrated, in the Outer House by the Lord Ordinary (Lord Lea), as follows: "The law of Scotland is not deficient in authority upon the principles and limits of jurisdiction in civil actions. . . . The result of many decisions, to which it is now unnecessary to refer, is very distinctly brought out in McMillan v. The Free Church of Scotland." 2 In that case a minister, who had been deposed by the defendant association, brought an action against them for reduction and damages. Lord Lea adopted the principle, upon which the conclusion for reduction could not be sustained to the effect of preventing an association from expelling one of its members, or of ordering them to receive him back as a member, as set forth by Lord Deas as follows ${ }^{3}$ : "It is not because the office of a clergyman is a holy office,--it is not because those who ordained or deposed him did so by divine

${ }^{1}$ (1885) 12 R. p. $1206 .{ }^{2}$ (1861) 23 D.p. 1314. ${ }^{3}$ I bid.,p. 1316.

(a) As to this specific limitation of the Court's jurisdiction, vide supra, Chapter V. 
authority,-it is not because the Church he belongs to is a Christian Church,-it is not because the object of the association is a religious object, - that we decline to interfere further than I have indicated. It is simply because this Court deals only with civil or patrimonial interests and consequences, and, while vindicating or giving redress for these, refuses to go beyond them. It is upon the same ordinary principle, that if no civil interests are involved, we refuse to interfere at all. Men may associate themselves together for innumerable purposes, under rules and regulations, which may be called, if you please, a contract of agreement, but of the breach or observance of which the law will take no cognizance. It is of no moment whether these purposes be trivial or important, temporal or spiritual, scientific or religious, so long as they do not involve civil or patrimonial rights." Lord Lea then continued : ${ }^{1}$ "There are, it is true, many questions involving no pecuniary or patrimonial interest, which are competent to this Court. Erskine gives, as examples of such questions, the election of magistrates of burghs, and commissioners of supply. Those are public offices. But there are also questions of personal status, which, as affecting civil rights, are equally competent to the Court. It is, however, "without doubt," as Erskine says, that "private right or property is the chief and most proper subject of the Court's jurisdiction ; and there is no authority that I am aware of, for the Court's interference in regard to the mere

(1885) 12 R., at p. 1209. 
membership of voluntary associations." His Lordship proceeded to indicate that, if the alleged error of the majority of the association affected no civil right, of which the law took cognizance, and merely involved the continuation of an association terminable at will, or unrecognizable by the law, then the Court could not interfere, for it had no means of compelling obedience to its decisions $(a)$.

\section{Procedure in Case of Registered Trade Union.}

Where it is competent for the Court to entertain an action, in the case of registered trade unions, the trade union may sue or be sued in its registered name, service being effected at the registered office of the trade union. A judgment, however, against such trade union can only be enforced against its property, and to reach that property it may be necessary to sue the trustees also, for, it is expressly provided by statute that, in the case of a registered trade union, the trustees or other officers duly authorized by the rules may bring or defend any action or prosecution concerning the property of the union." They sue or are

1 Taff Vale Railway Company v. Amalgamated Society of Railway Servants [1901] A. C. 426.

(a) In England, since 1883, R. S. O. Ord. xxv., r. 5. In the Courts have jurisdiction to make declarations without granting consequential relief; per Fletcher Moulton, L.J., in Gozney v. Bristol Trade and Pro. vident Society, [1909] 1 K. B. 901, and Osborne v. Amalgamated Society of Railway Servants (No. 2), [1911] 1 Ch. 540 ; Scotland, however, the practice would seem to be different, and the Courts decline to pronounce a decree in a form in which they cannot enforce it; per Lord Inglis in Aitken v. Associated Carpenters and Joiners of Scotland, (1885) 12 R. 1206. 
sued in their names without any other description than the title of their office $(a)$, and summonses may be issued against such trustees by being left at the registered office of the union $(b)$. The property of the union is to be stated in all actions to be the property of the trustees $(c)$, but such property, held by the trustees, is nevertheless the property of the union; trade unions, not being incorporated, had recourse to the old well-known machinery of trustees for acquiring, holding property and for suing and being sued in respect of it, but the union is the beneficial owner. ${ }^{1}$ An official, therefore, suing for salary, should make the trustees defendants, for the judgment concerns the property of the union. ${ }^{2}$

Trustees may be sued personally, either in contract, or in tort $(d)$, when they are the legal owners of property of the union, so as to bind the union funds, and in such case may be indemnified for damages awarded against them, out of the funds of the union, ${ }^{3}$ and in an action against a trade union, the Court may add the trustees as defendants. ${ }^{*} \quad$ Generally, a slight technical error of procedure in authorising trustees to bring actions, etc. (as when a standing committee giving authority

1 Per Lord Lindley, [1901] A. C. 426 , at p. 444 .

2 Curle v. Lester, (1893) 9 T. I. R. 480 .

(a) Except in respect of torts committed by or on behaif of the trade union in contemplation or furtherance of a trade dispute, for which they are not suable, supra, pp. 73 and 74 .
3 Linaker v. Pilcher, (1901) 84 I. T. 421.

4 Yorkshire Miners' Association v. Howden, [1905] A. C. 256.

(b) (1871) 34 \& 35 Vict. c. 31, s. 9 .

(c) Ibid., s. 8 .

(d) Where there is no trade dispute in furtherance or contemplation, supra, pp. 73 and 74 . 
to the trustees so to do was one short of the prescribed number of members) will not of itself invalidate the action either by or against the trustees. ${ }^{1}$

Procedure in Case of Unregistered Trade Union.

A part from this procedure, which is only applicable In England. in the case of a registered trade union; in England, a trade union (among other associations), whether unregistered or registered, may sue or be sued in a "representative action " $(a)$, if the persons selected as plaintiffs or defendants be persons who, from their position, may be fairly taken to represent the In trade union. ${ }^{2}$ As regards Ireland, a similar proIreland. vision ebtains $(b)$.

Representative persons.

The persons selected should, if possible, be persons who are managers of the union, having control over it or its funds, such as the executive committec and the trustees. ${ }^{3} \quad$ The persons suing or being sued must have, at least, a common interest with those whom they represent. ${ }^{4}$ The president and secretary of trade unions, where there are no trustees, or where trustees have not such management, control, common interest or representative capacity, may be held not to be proper persons to sue or be sued as representing the union for an action founded in tort, ${ }^{5}$ but they are apparently sufficiently representa-

1 M'Laren v. Miller, (1880) 7 R. 867.

2 Yorkshire Miners' Association v. Howden, [1905] A. C. 256 ; Taff Vale Railway Company v. Amalyamated Society of Railway Servants, [1901] A. C. 426.
3 Per Lord Macnaghten, ibid., at p. 439.

4 Duke of Bedford $\nabla$. Ellis, [1901] A. C. 1 .

5 'T'emperton v. Russell, [1893] 1 Q. 13. 435.

(a) R. S. C., Ord. XVI., r. $9 . \quad$ (b) R. S. C. (Ir.),Ord. III., r. 4. 
tive to be sued when the plaintiff is endeavouring to sue in contract to establish a beneficial proprietary right. ${ }^{1}$

When the persons selected are not sufficiently representative to sue as plaintiffs, the Courts may add others to remedy the deficiency ${ }^{2}$; so, also, persons may be made representative defendants even against their will. ${ }^{3}$ Generally, the Court has power to join claims against defendants in trade union actions when it is of opinion that the right to relief arises out of the same series of transactions $(a)$. Thus, where an injunction was claimed to prevent several defendants from watching and besetting certain places for the purpose of preventing workmen from offering their services to a master, it was held that such defendants could be properly joined in one action. ${ }^{4}$

In Scotland trade unions may sue or be sued in the Procedure general name of the trade union, with the addition in scotland. of the names of three of the members $(b)$.

Right of Trade Union to Conduct Actions for Members.

A trade union may, out of its funds, pay the legal expenses of a member when there is a common

1 Wood v. McCarthy, [1893] 1 Wholesale Societies, Ltd. v. GlasQ. B. 775 .

${ }^{2}$ Clarnock v. Court and Others, [1899] 2 Ch. 3j.

${ }^{3}$ Wood v. McCarthy, [1893] 1 Q. B. 435 ; Scottish Co-operative gow Fleshers' Trude Defence Association, (1898) 35 S. L. R. 645.

${ }^{4}$ Walters v. Green, [1899]'2 Ch. 696.

(a) Ord. XVI., r. 1.

(b) Court of Session Practice (Mackay). Even the three members are apparently un-

T.U.

necessary. Agnew v. Addison, (1893) 20 R. (J. C.) 19 ; Smith v. Lothian, (1862) 4 Ir. V. 170. 
interest $(a)$ between the member and the trade union, ${ }^{1}$ but it cannot bring an action, even with his consent; when there is no common interest between him and the union, and to do so may amount to the offence of "maintenance," which is a misdemeanor."

How far
legitimate. The fact that it is an express object of a trade union to give legal aid to members in their relations with employers will not cover the case of a union supporting the claims of a member for such an extraneous matter as an alleged libel, ${ }^{3}$ for, generally, unless the defence of a member of the union is vital to the interests of the union, the union will not have the right to employ the union funds for that member's defence. ${ }^{4}$

Maintenance of action not

When the union are entitled, and have agreed, to a benefit. pay the costs of a member's legal proceedings, such an agreement is not an agreement "to provide a benefit to a member" within the meaning of section 4 of the 1871 Act, and is therefore enforceable by the Court, ${ }^{5}$ and when such an agreement to pay a member's costs is made by a branch, the agreement may bind the parent union. ${ }^{6}$ Where the officers of

1 Gordon v. Pyper, (1893) 20 R. (H. L.) 23 ; Yorkshire Miners' Association v. Howden, [1905] A. C. 256.

2 Bradlaugh v. Newdegate, (1883) 11 Q. B. D. 1.

3 Greig v. National Amalgamated Union of Shop Assistants, (1906) 22 T. I. R. 274.

(a) In which case, informa. tion in support of an action supplied by a member to the officers of a trade union or by
4 Alfin v. Hewlett, (1901) 18 T. L. R. 664.

${ }_{5}^{5}$ Lees v. Lancashire and Cheshire Miners' Federation, (1906) Times, June 20th.

- Mackendrick $\quad$ v. National Union of Dock Labourers, (1911) 48 S. L. R. 17.

them to their solicitor is not privileged as between solicitor and client. Jones v. Great Central Railway Co., [1910] A. C. 4. 
a trade union have committed a breach of trust Rights of against the members, no right of action is thereby parties. conferred upon third partie, such as employers who have no interest in the funds. ${ }^{1}$

With regard to the relations of a trade union to its branches, generally a trade union may bring an of trade action against the trustees of a branch to determine union to branch. the title of property held by the branch ${ }^{2}$; so, also, the branch trustees may be restrained by injunction at the suit of the trustees of the parent union. ${ }^{3}$

While the excepted agreements contained in section 4 of the 1871 Act are not unlawful, no legal proceeding instituted with the object of directly enforcing or recovering damages for the Procedure under the Trade Union Act, 1871 , section 4. breach of any of them will be entertained by any Court (a).

In England, the question has arisen whether the exception to jurisdiction can be pleaded on appeal, where it has not been taken in the inferior Court. Pleading of statutory defence. In Strick v. Swansea Tin Plate Company ${ }^{4}$ North, J., decided this question in the negative. But in Burke v. Amalgamated Society of Dyers, ${ }^{5}$ where the fact was mentioned in the course of the argument that the

1 Denaby and Cadeby Main Collieries, Ltd., v. Yorkshire Miners' Association, [1906] A. C. 384, at p. 393. On the question of costs in this case the Court refused to vary an order of the Taxing Master allowing the defendants only two counsel. Ibid., (1907) 23 T. L. R. 635.
2 Madden v. Rhodes, [1906] 1 K. B. 534.

s Cope v. Crossingham, [1909] 2 Ch. 148; Duke v. Littleboy, (1880) 49 I. J. Ch. 802; M'Laren v. Miller, (1880) $7 \mathrm{R}$. 867.

4 (1887) 36 Ch. D. 558.

5 [1906] 2 K. B. 583.

(a) Supra, Chapter V.; (1871) 34 \& 3j Vict. c. 31, s. 4. 
plea to jurisdiction had not been taken in the inferior Court, ${ }^{1}$ Kennedy, J., nevertheless entertained that plea in the Divisional Court. ${ }^{2}$ An action by a member, unenforceable in virtue of section 4 of the 1871 Act, remains unenforceable by that member's representative (whether by decease or assignment). ${ }^{3}$

Competency of sheriff Court.

In Scotland, a curious point with regard to jurisdiction under this section is raised by the SmallDebts (Scotland) Act (a). Under it decrees of a sheriff may be reviewed by the Court of Justiciary on the ground, inter alia, of incompetency, including defect of jurisdiction of the Sheriff. It has been held ${ }^{4}$ that the question whether an action based on a contract between a deceased member and his trade union was or was not excluded as being within the excepted agreements of section 4, was one of which the Sheriff was alone the competent juidge, and that there could be no objection to his jurisdiction.

\section{Criminal Procedure.}

Criminal procedure in

England and Ireland.

As regards procedure in criminal matters in England and Ireland, every offence and penalty which is summarily punishable or recoverable under the Trade Unions Acts, 1871 and 1876, or the Conspiracy and Protection of Property Act, 1875, must be prosecuted and recovered in the manner provided

1 Ibid., at p. 586.

2 Ibid., at p. 590. See also General Union Society of Operative Carpenters and Joiners v. O'Donnel, (1877) 11 Ir. I. T. 282.
3 Winder v. Guardians of Kingston-upon-Hull Corporation, (1888) 20 Q. B. D. 412.

4 In Alison v. Balmain, (1883) 10 R. 12.

(a) (1837) 1 Vict. c. 41 , s. 31. 
by the Summary Jurisdiction Acts $(a)$. The jurisdiction under the 1871 Act may be exercised for the Under the Act of place where the office of the trade union is situated 1871. or where the offence has been committed. The costs on summary conviction must not exceed $£ 1(b)$, and they and all offences and penalties may be prosecuted and recovered summarily $(c)$. Under the 1875 Act, where a person is accused before a Court of Summary Jurisdiction of any offence, Under the Act of for which a penalty of $£ 20$ or imprisonment is imposable, the accused may, on appearing before the Court of Summary Jurisdiction, declare that he objects to being tried for such offence summarily and may claim to be tried by indictment $(d)$.

\section{Constitution of Court.}

For the purposes of both Acts the "Court of Summary Jurisdiction" must be constituted in some one of the following manners :-

(A) In England,

(1) In any place within the jurisdiction of a metropolitan police magistrate or other stipendiary magistrate, of such magistrate or his substitute;

(2) In the City of London, of the Lord Mayor or any alderman of the city;

(a) (1871) $34 \& 35$ Vict. c. 31 , s. $19 ;(1875) 38 \& 39$ Vict. c. 86 , s. 10 ; (1879) $42 \& 43$ Vict. c. 49 ; (1884) $47 \& 48$ Vict. c. 43 . As to summary procedure generally, see Stone's Justices' Manual, 43rd ed.

(b) (1871) 34 \& 35 Vict. c. 31 , s. 19 .

(c) (1876) $39 \& 40$ Vict. c. 22 , s. 5. Stone's Justices' Manual, 43rd ed., pp. 33 et seq.

(d) (1875) 38 \& 39 Vict. c. 86 , s. 9 . In trial by indictment it is not necessary to aver in the indictment that the defendant elected to be so tried. $R$. v. Chambers, (1896) 18 Cox, C. C. 401.
Court of first instance in England. 
In Ireland. (B) In Ireland,

(3) In any other place, of two or more justices of the peace sitting in petty sessions.

(1) In the police district of Dublin Metropolis, of a divisional justice;

(2) In any other place, of a resident magistrate $(a)$.

Appeal.

If any party feels aggrieved by any order or conviction made by such a Court of Summary Jurisdiction on determining any complaint or information, the party so aggrieved may appeal therefrom, subject to the following conditions and regulations :-

Appeal in England.

(A) In England,

(1) The appeal must be made to the prescribed Court of Generalor Quarter Sessions, or if no Court is prescribed, to the next practicable Court of General or Quarter Sessions having jurisdiction in the county borough or place for which the said Court of Summary Turisdiction acted, and holden not less than fifteen days after the day on which the decision was given upon which the conviction or order was founded ;

(2) 'The appellant must, within the prescribed time, or if no time is prescribed within seven days after the day on which the said decision of the Court was given, give notice of appeal by serving on the other party and on the clerk of the said Court

(a) (1871) $34 \& 35$ Vict. c. 31 , s. 19 ; (1875) 38 \& 39 Vict. c. 86 ss. 13 and 21. 
of Summary Jurisdiction notice in writing of his intention to appeal, and of the general grounds of such appeal;

(3) The appellant must, within the prescribed time, or if no time is prescribed within three days after the day on which he gave notice of appeal, enter into a recognizance before a Court of Summary Jurisdiction, with or without a surety or sureties as that Court may direct, conditioned to appear at the said sessions and to try such appeal, and to abide the judgment of the Court of Appeal thereon, and to pay such costs as may be awarded by the Court of Appeal, or the appellant may, if the Court of Summary Jurisdiction before whom the appellant appears to enter into a recognizance think it expedient, instead of entering into a recognizance, give such other security, by deposit of money with the clerk of the Court of Summary Jurisdiction or otherwise, as that Court deem sufficient;

(4) Where the appellant is in custody, the Court of Summary Jurisdiction before whom the appellant appears to enter into a recognizance may, if the Court think fit, on the appellant entering into such recognizance or giving such other security as aforesaid, release him from custody ;

(5) The Court of Appeal may adjourn the hearing of the appeal, and upon the hearing thereof may confirm, reverse, or 
modify the decision of the Court of Summary Jurisdiction, or remit the matter, with the opinion of the Court of Appeal thereon, to a Court of Summary Jurisdiction acting for the same county borough or place as the Court by whom the conviction or order appealed against was made, or may make such other order in the matter as the Court of Appeal may think just, and may by such order exercise any power which the Court of Summary Jurisdiction might have exercised, and such order shall have the same effect, and may be enforced in the same manner, as if it had been made by the Court of Summary Jurisdiction. The Court of Appeal may also make such order as to costs to be paid by either party as the Court may think just;

(6) Whenever a decision is not confirmed by the Court of Appeal, the clerk of the peace shall send to the clerk of the Court of Summary Jurisdiction from whose decision the appeal was made, for entry in his register, and also indorse on the conviction or order appealed against, a memorandum of the decision of the Court of Appeal, and whenever any copy or certificate of such conviction or order is made, a copy of such memorandum shall be added thereto, and shall be sufficient evidence of the said decision in every case where such copy or certificate would 
be sufficient evidence of such conviction or order;

(7) Every notice in writing required to be given by an appellant must be in writing signed by him, or by his agent on his behalf, and may be transmitted as a registered letter by the post in the ordinary way, and shall be deemed to have been served at the time when it would be delivered in the ordinary course of the post $(a)$.

(B) In Ireland,

(1) The appeal must be made to some Court Appeal in of General or Quarter Sessions which must be for the county or place in which the cause of appeal has arisen, holden not less than fifteen days and not more than four months after the decision of the Court from which the appeal is made ;

(2) The appellant must within seven days after the cause of appeal has arisen, give notice to the other party and to the clerk of the Court of Summary Jurisdiction of his intention to appeal and of the ground thereof :

(3) The appellant must after such notice immediately enter into a recognizance before a justice of the peace in the sum of ten pounds, with two sufficient sureties in the sum of ten pounds, conditioned

(a) (1879) $42 \& 43$ Vict. c. 49 , s. 31 ; (1881) 47 \& 48 Vict. c. 43, s. 4 . 
personally to prosecute such appeal, and to abide the judgment of the Court thereon, and to pay such costs as may be awarded by the Court;

(4) Where the appellant is in custody the justice may, if he think fit, on the appellant entering into such recognizance as aforesaid, release him from custody ;

(5) The Court of Appeal may adjourn the appeal, and, upon the hearing thereof, may confirm, reverse, or modify the decision of the Court of Summary Jurisdiction, or remit the matter to the Court of Summary Jurisdiction, in which event the said lastmentioned Court shall thereupon re-hear and decide the information or complaint in accordance with the opinion of the said Court of Appeal. The Court of Appeal may also make such order as to costs to be paid by either party as the Court thinks just $(a)$.

It appears that, as regards England and Ireland, the dismissal of a charge may also be appealed against. $^{1}$

Constitution of Court and Appeal in Scotland.

Constitu-

tion of Court.
(C) In Scotland,

All offences and penalties must be prosecuted and recovered by the procurator fiscal of the county in the Sheriff

1 Gibson v. Lawson, [1891]2 Q. B. 545, at p. 557.

(a) (1871) $34 \& 35$ Vict. c. 31 , s. 12. 
Court under the provisions of the Summary Procedure Act, 1864. And in the case of offences under the 1875 Act, where a person is entitled to be tried on indictment, the proceedings may be taken in the Court of Justiciary, and generally, under the 1875 Act, offences may be prosecuted at the instance of the Lord Advocate as well as at the instance of the prosecutor fiscal. Summary orders under this Act may be made and enforced on complaint in the Sheriff Court. All the jurisdictions, powers, authorities necessary for giving effect to these provisions relating to Scotland are conferred on the sheriffs and their substitutes.

Penalties may be enforced in default of Penalties. payment by imprisonment for a term to be specified in the summons or complaint, but not exceeding in the case of the 1871 Act, or in the case of the 1875 Act, two calendar months. All penalties must be paid to the sheriff clerk, and must be accounted for and paid by him to the King's and Lord Treasurer's Remembrancer on behalf of the Crown $(a)$.

It is competent to any person to appeal against any order or conviction under Appeal in Scotland. both the 1871 and 1875 Acts, to the High Court of Justiciary, in the manner prescribed by and under the rules,

(a) (1871) $34 \& 35$ Vict. c. 31 , ss. 19,21 ; (1875) $38 \& 39$ Vict. c. 86, s. 19 . 
limitations, conditions, and restrictions contained in the Heritable Jurisdictions (Scotland) Acts, 1846 (a), with regard to appeals to Circuit Courts in matters criminal, as the same may be altered or amended by any Acts of Parliament for the time being in force $(b)$.

\section{General Provisions.}

Interested Generally, with regard to the constitution of the
justices. Courts of Summary Jurisdiction or Appeal in trying offences incurred under the 1871 Act, in all three countries a person who is a master, or father, son, or brother of a master, in the particular manufacture, trade, or business in or in connection with which any offence under this Act is charged to have been committed, may not act as, or as a member of, such a Court $(c)$. There is no such statutory provision as to a Court constituted to try offences under the Act of 1875 , though in the case of a prosecution under that Act, bias on the part of the Court may be alleged by way of objection to its constitution. The fact that a justice, convicting under that Act, is a shareholder in a company, which is a constituent of a federation of which the prosecutor is an official, is not however a sufficient bias to nullify the conviction. ${ }^{1}$

Description of offence,

Generally, also, the description of any offence, in 1 R. v. McKenzie, [1892] 2 Q. B. 43.

(a) (1746) 20 Geo. II. c. 2 , s.

(c) (1871) $34 \& 35$ Vict. c. 31 ,

(b) (1871) $34 \& 35$ Vict. c. 31 , s. 20 ; (1875) $38 \& 39$ Vict. c. 86 , s. 21 ; (1875) $38 \& 39$ Vict. c. 86 , s. 12. Stone's Justices Manual, s. 19 . 
the words of the Trade Union Acts, 1871 and 1876, is sufficient in law. Any exception, exemption, proviso, excuse, or qualification, whether it does or does not accompany the description of the offence alleged may be proved by the defendant, but need not be specified or negatived in the information, and, if so specified or negatived, no proof in relation to the matters so specified or negatived is required on the part of the informant or prosecutor $(a)$, but when the defect in description is one of substance and not merely of form, the conviction may be quashed. ${ }^{1}$

As regards offences under the Act of 1875, where intimidation is alleged the specific acts of In indictment. intimidation must be stated in the conviction, ${ }^{2}$ so also where the offence consists in preventing a person from performing acts, the specific acts must be stated, ${ }^{3}$ but a commitment for "following in a disorderly way with a view to compel A. to abstain from working in the employment of $B$. as a shoe finisher" is a sufficiently specific description. ${ }^{4}$ To allegre "violence or intimidation" as alternate counts in an indictment is bad for duplicity. ${ }^{5}$ Where the offence consists in injuring property the conviction must specify the particular property injured. ${ }^{6}$

1 R. v. McKenzie, [1892] 2 Q. B. 519 .

2 Metcalf v. Wiseman, (1889) 52 J. P. 439. But see Clarkson v. Stuart, (1895) 22 R. (J.) 5.
3 R. v. McKenzie, [1892]
K. B. 56.

Q. B. 519 .
4 Ex parte Wilkins, (1895) 64

L. J. M. C. 221.

5 R. v. Eidmondes, (1874) 59

J. P. 776.

6 Smith v. Moody, [1903] 1

(a) (1871) $34 \& 35$ Vict. c. 31 , s. 19 



\section{APPENDICES.}

STATUTES, REGULATIONS, FORMS, RULES.

\section{APPENDIX I.}

STATUTES.

(a) THE TRADE UNION ACT, 1871.

[34 \& 35 VICT. с. 31.]

Preliminary.

1. This Act may be cited as "The Trade Union Act, Short 1871."

title.

\section{Criminal Provisions.}

2. The purposes of any trade union shall not, by Trade reason merely that they are in restraint of trade, be deemed to be unlawful, so as to render any member of union not criminal. such trade union liable to criminal prosecution for conspiracy or otherwise.

3. The purposes of any trade union shall not, by Trade reason merely that they are in restraint of trade, be unlawful so as to render void or voidable any agreement or trust.

4. Nothing in this Act shall enable any court to entertain any legal proceeding instituted with the object of directly enforcing or recovering damages for the breach of any of the following agreements, namely,

(1.) Any agreement between members of a trade union not unlawful for civil purposes.

\section{Trade} union contracts when not enforceunion as such, concerning the conditions on which any members for the time being of such trade union shall or shall not sell their goods, transact business, employ, or be employed: 
(2.) Any agreement for the payment by any person of any subscription or penalty to a trade union:

(3.) Any agreement for the application of the funds of a trade union,-

(a.) To provide benefits to members; or,

(b.) To furnish contributions to any employer or workman not a member of such trade union, in consideration of such employer or workman acting in conformity with the rules or resolutions of such trade union; or

(c.) To discharge any fine imposed upon any person by sentence of a court of justice; or,

(4.) Any agreement made between one trade union and another; or,

(5.) Any bond to secure the performance of any of the above-mentioned agreements.

But nothing in this section shall be deemed to constitute any of the above-mentioned agreements unlawful.

Provisions of $18 \&$ 19 Vict. c. 63 , $30 \&$ 31 Vict. c. 117 , $25 \&$

26 Vict. c. 89, \&c., not to apply to trade unions.

liegistry of trade unions.
5. The following Acts, that is to say,

(1.) The Friendly Societies Acts, 1855 and 1858, and the Acts amending the same;

(2.) The Industrial and Provident Societies Act, 1867, and any Act amending the same; and

(3.) The Companies Acts, 1862 and 1867, shall not apply to any trade union, and the registration of any trade union under any of the said Acts shall be void, and the deposit of the rules of any trade union made under the Friendly Societies Acts, 1855 and 1858, and the Acts amending the same, before the passing of this Act, shall cease to be of any effect.

\section{Registered Trade Unions.}

6. Any seven or more members of a trade union may by subscribing their names to the rules of the union, and otherwise complying with the provisions of this Act with respect to registry, register such trade union under this Act, provided that if any one of the purposes of such trade union be unlawful such registration shall be void. 
7. It shall be lawful for any trade union registered under this Act to purchase or take upon lease in the names of the trustees for the time being of such union any land not exceeding one acre, and to sell, exchange, mortgage or let the same, and no purchaser, assignee, mortgagee, or tenant shall be bound to inquire whether the trustees have authority for any sale, exchange, mortgage, or letting, and the receipt of the trustees shall be a discharge for the money arising therefrom; and for the purpose of this section every branch of a trade union shall be considered a distinct union.

8. All real and personal estate whatsoever belonging to any trade union registered under this Act shall be vested in the trustees for the time being of a trade union appointed as provided by this Act for the use and benefit of such trade union and the members thereof, and the real or personal estate of any branch of a trade union shall be vested in the trustees of such branch, and be under the control of such trustees, their respective executors or administrators, according to their respective claims and interests, and upon the death or removal of any such trustees the same shall vest in the succeeding trustees for the same estate and interest as the former trustees had therein, and subject to the same trusts, without any conveyance or assignment whatsoever, save and except in the case of stocks and securities in the public funds of Great Britain and Ireland, which shall be transferred into the names of such new trustees; and in all actions, or suits, or indictments, or summary proceedings before any court of summary. jurisdiction, touching or concerning any such property, the same shall be stated to be the property of the person or persons for the time being holding the said office of trustee, in their proper names, as trustees of such trade union, without any further description.

9. The trustees of any trade union registered under this Act, or-any other officer of such trade union who may be authorised so to do by the rules thereof, are hereby empowered to bring or defend, or cause to be brought or defended, any action, suit, prosecution or complaint in any court of law or equity touching or concerning property, right, or claim to property of the

Property of the trade unions vested in trustees.
Actions, etc., by or against trustees, etc.

T.U. 
trade union; and shall and may, in all cases concerning the real or personal property of such trade union, sue and be sued, plead and be impleaded, in any court of law or equity, in their proper names, without other description than the title of their office; and no such action, suit, prosecution, or complaint shall be discontinued or shall abate by the death or removal from office of such persons or any of them, but the same shall and may be proceeded in by their successor or successors as if such death, resignation, or removal had not taken place; and such successors shall pay or receive the like costs as if the action, suit, prosecution, or complaint had been commenced in their names for the benefit of or to be reimbursed from the funds of such trade union, and the summons to be issued to such trustee or other officer may be served by leaving the same at the registered office of the trade union.

Limitation of responsibility of trustees.

10. A trustee of any trade union registered under this Act shall not be liable to make good any deficiency which may arise or happen in the funds of such trade union, but shall be liable only for the moneys which shall be actually received by him on account of such trade union.

Treasurers, 11. Every treasurer or other officer of a trade union etc., to account. registered under this Act, at such times as by the rules of such trade union he should render such account as herein-after mentioned, or upon being required so to do, shall render to the trustees of the trade union, or to the members of such trade union, at a meeting of the trade union, a just and true account of all moneys received and paid by him since he last rendered the like account, and of the balance then remaining in his hands, and of all bonds or securities of such trade union, which account the said trustees shall cause to be audited hy some fit and proper person or persons by them to ve appointed; and such treasurer, if thereunto required, upon the said account being audited, shall forthwith hand over to the said trustees the balance which on such audit appears to be due from him, and shall also, if required, hand over to such trustees all securities and effects, books, papers, and property of the said trade union in his hands or custody; and if he fail to do 
so the trustees of the said trade union may sue such treasurer in any competent court for the balance appearing to have been due from him upon the account last rendered by him, and for all the moneys since received by him on account of the said trade union, and for the securities and effects, books, papers, and property in his hands or custody, leaving him to set off in such action the sums, if any, which he may have since paid on account of the said trade union; and in such action the said trustees shall be entitled to recover their full costs of suit, to be taxed as between attorney and client.

12. If any officer, member, or other person being or representing himself to be a member of a trade union registered under this Act, or the nominee, executor, administrator, or assignee of a member thereof, or any person whatsoever, by false representation or imposition obtain possession of any moneys, securities, books, papers, or other effects of such trade union, or, having the same in his possession, wilfully withhold or fraudulently misapply the same, or wilfully apply any part of the same to purposes other than those expressed or directed in the rules of such trade union, or any part thereof, the court of summary jurisdiction for the place in which the registered office of the trade union is situate upon a complaint made by any person on behalf of such trade union, or by the registrar, or in Scotland at the instance of the procurator fiscal of the court, to which such complaint is competently made, or of the trade union, with his concurrence, may, by summary order, order such officer, member, or other person to deliver up all such moneys, securities, books, papers, or other effects to the trade union, or to repay the amount of money applied improperly, and to pay, if the court think fit, a further sum of money not exceeding twenty pounds, together with costs not exceeding twenty shillings; and, in default of such delivery of effects, or repayment of such amount of money, or payment of such penalty and costs aforesaid, the said court may order the said person so convicted to be imprisoned, with or without hard labour, for any time not exceeding three months: Provided, that nothing herein contained shall prevent the said trade union, or in Scotland Her Majesty's Advocate, from proceeding by indictment

Punish. ment for withholding money, etc. 
against the said party; provided also, that no person shall be proceeded against by indictment if a conviction shall have been previously obtained for the same offence under the provisions of this Act.

\section{Registry of Trade Union.}

Regulations for registry.
13. With respect to the registry, under this Act, of a trade union, and of the rules thereof, the following provisions shall have effect:

(1.) An application to register the trade union and printed copies of the rules, together with a list of the titles and names of the officers, shall be sent to the registrar under this Act:

(2.) The registrar, upon being satisfied that the trade union has complied with the regulations respecting registry in force under this Act, shall register such trade union and such rules:

(3.) No trade union shall be registered under a name identical with that by which any other existing trade union has been registered, or so nearly resembling such name as to be likely to deceive the members or the public:

(4.) Where a trade union applying to be registered has been in operation for more than a year before the date of such application, there shall be delivered to the registrar before the registry thereof a general statement of the receipts, funds, effects, and expenditure of such trade union in the same form, and showing the same particulars, as if it were the annual general statement required as herein-after mentioned to be transmitted annually to the registrar:

(5.) The registrar upon registering such trade union shall issue a certificate of registry, which certificate, unless proved to have been withdrawn or cancelled, shall be conclusive evidence that the regulations of this Act with respect to registry have been complied with:

(6.) One of Her Majesty's Principal Secretaries of State may from time to time make regulations respecting registry under this Act, and respecting the seal (if any) to be used for the 
purpose of such registry, and the forms to be used for such registry, and the inspection of documents kept by the registrar under this Act, and respecting the fees, if any, to be paid on registry, not exceeding the fees specified in the second schedule to this Act, and generally for carrying this Act into effect.

14. With respect to the rules of a trade union registered under this Act, the following provisions shall have effect:

(1.) The rules of every such trade union shall contain provisions in respect of the several matters mentioned in the first schedule to this Act:

(2.) A copy of the rules shall be delivered by the trade union to every person on demand on payment of a sum not exceeding one shilling.

15. Every trade union registered under this Act shall have a registered office to which all communications and notices may be addressed; if any trade union under this Act is in operation for seven days without having such an office, such trade union and every officer thereof shall each incur a penalty not exceeding five pounds for every day during which it is so in operation.

Notice of the situation of such registered office, and of any change therein, shall be given to the registrar and recorded by him; until such notice is given the trade union shall not be deemed to have complied with the provisions of this Act.

16. A general statement of the receipts, funds, effects, and expenditure of every trade union registered under this Act shall be transmitted to the registrar before the first day of June in every year, and shall show fully the assets and liabilities at the date, and the receipts and expenditure during the year preceding the Rules of registered trade unions.

Registered office of trade unions. date to which it is made out, of the trade union; and shall show separately the expenditure in respect of the several objects of the trade union, and shall be prepared and made out up to such date, in such form, and shall comprise such particulars, as the registrar may from time to time require; and every member of, and depositor in, any such trade union shall be entitled to receive, on application to the treasurer or secretary of

Annual returns to be prepared as registrar may direct. 
that trade union, a copy of such general statement, without making any payment for the same.

Together with such general statement there shall be sent to the registrar a copy of all alterations of rules and new rules and changes of officers made by the trade union during the year preceding the date up to which the general statement is made out, and a copy of the rules of the trade union as they exist at that date.

Every trade union which fails to comply with or acts in contravention of this section, and also every officer of the trade union so failing, shall each be liable to a penalty not exceeding five pounds for each offence.

Every person who wilfully makes or orders to be made any false entry in or any omission from any such general statement, or in or from the return of such copies of rules or alterations of rules, shall be liable to a penalty not exceeding fifty pounds for each offence.

Registrars. 17. The registrars of the friendly societies in England, Scotland, and Ireland shall be the registrars under this Act.

The registrar shall lay before Parliament annual reports with respect to the matters transacted by such registrars in pursuance of this Act.

Circulating false copies of rules, etc., a misdemeanor.

18. If any person with intent to mislead or defraud gives to any member of a trade union registered under this Act, or to any person intending or applying to become a member of such trade union, a copy of any rules or of any alterations or amendments of the same other than those respectively which exist for the time being on the pretence that the same are the existing rules of such trade union, or that there are no other rules of such trade union, or if any person with the intent aforesaid gives a copy of any rules to any person on the pretence that such rules are the rules of a trade union registered under this Act which is not so registered, every person so offending shall be deemed guilty of a misdemeanor.

\section{Legal Proceedings.}

Summary proeeedings for offences,

19. In England and Ireland all offences and penalties under this Act may be prosecuted and recovered in manner directed by the Summary Jurisdiction Acts. 
In England and Ireland summary orders under this Act may be made and enforced on complaint before a penalties, court of summary jurisdiction in manner provided by the Summary Jurisdiction Acts.

Provided as follows:

1. The "Court of Summary Jurisdiction," when hearing and determining an information or complaint, shall be constituted in some one of the following manners ; that is to say,

(A.) In England,

(1.) In any place within the jurisdiction of a metropolitan police magistrate or other stipendiary magistrate, of such magistrate or his substitute:

(2.) In the city of London, of the Lord Mayor or any alderman of the said city:

(3.) In any other place, of two or more justices of the peace sitting in petty sessions.

(в.) In Ireland,

(1.) In the police district of Dublin metropolis, of a divisional justice:

(2.) In any other place, of a resident magistrate.

In Scotland all offences and penalties under this Act shall be prosecuted and recovered by the procurator fiscal of the county in the Sheriff Court under the provisions of the Summary Procedure Act, 1864.

In Scotland summary orders under this Act may be made and enforced on complaint in the Sheriff Court.

All the jurisdictions, powers, and authorities necessary for giving effect to these provisions relating to Scotland are hereby conferred on the sheriffs and their substitutes.

Provided that in England, Scotland, and Ireland-

2. The description of any offence under this Act in the words of such Act shall be sufficient in law.

3. Any exception, exemption, proviso, excuse, or qualification, whether it does or not accompany the description of the offence in this Act, may be proved by the defendant, but need not be specified or negatived in the information, and if so specified or negatived, no proof in relation to the matters so specified or negatived shall be required on the part of the informant or prosecutor. 
Appeal to quarter sessions.

20. In England or Ireland, if any party feels aggrieved by any order or conviction made by a court of summary jurisdiction on determining any complaint or information under this Act, the party so aggrieved may appeal therefrom, subject to the conditions and regulations following:

(1.) The appeal shall be made to some. court of general or quarter sessions for the county or place in which the cause of appeal has arisen, holden not less than fifteen days and not more than four months after the decision of the court from which the appeal is made:

(2.) The appellant shall, within seven days after the cause of appeal has arisen, give notice to the other party and to the court of summary jurisdiction of his intention to appeal, and of the ground thereof:

(3.) The appellant shall immediately after such notice enter into a recognizance before a justice of the peace in the sum of ten pounds, with two sufficient sureties in the sum of ten pounds, conditioned personally to try such appeal, and to abide the judgment of the court thereon, and to pay such costs as may be awarded by the court:

(4.) Where the appellant is in custody the justice may, if he think fit, on the appellant entering into such recognizance as aforesaid, release him from custody:

(5.) The court of appeal may adjourn the appeal, and upon the hearing thereof they may confirm, reverse, or modify the decision of the court of summary jurisdiction, or remit the matter to the court of summary jurisdiction with the opinion of the court of appeal thereon, or make such other order in the matter as the court thinks just, and if the matter be remitted to the court of summary jurisdiction the said last-mentioned court shall thereupon re-hear and decide the information or complaint in accordance with the opinion of the said court of appeal. The court of appeal may also make such order as to costs to be paid by either party as the court thinks just. 
21. In Scotland it shall be competent to any person to appeal against any order or conviction under this Act to the next Circuit Court of Justiciary, or where there are no Circuit Courts to the High Court of Justiciary at Edinburgh, in the manner prescribed by and under the rules, limitations, conditions, and restrictions contained in the Act passed in the twentieth year of the reign of His Majesty King George the Second, chapter forty-three, in regard to appeals to Circuit Courts in matters criminal, as the same may be altered or amended by any Acts of Parliament for the time being in force.

All penalties imposed under the provisions of this Act in Scotland may be enforced in default of payment. by imprisonment for a term to be specified in the summons or complaint, but not exceeding three calendar months.

All penalties imposed and recovered under the provisions of this Act in Scotland shall be paid to the sheriff clerk, and shall be accounted for and paid by him to the Queen's and Lord Treasurer's Remembrancer on behalf of the Crown.

22. A person who is a master, or father, son, or brother of a master, in the particular manufacture, trade, or business in or in connexion with which any offence under this Act is charged to have been committed shall not act as or as a member of a court of summary jurisdiction or appeal for the purposes of this Act.

\section{Definitions.}

23. In this Act-

The term Summary Jurisdiction Acts means as follows:

As to England, the Act of the session of the eleventh and twelfth years of the reign of Her present Majesty, chapter forty-three, intituled "An Act to facilitate the performance of the duties of justices of the peace out of sessions within England and Wales with respect to summary convictions and orders," and any Acts amending the same:

As to Ireland, within the police district of Dublin metropolis, the Acts regulating the powers and
Appeal in

Scotland

as pre-

scribed by 20 Geo. 2, c. 43 .
Interested person not to act as a member of a court of appeal.

Defini-

tions.

As to the

term

"Stum-

mary

Jurisdic-

tion

Acts :" 
As to "trade union."

Repeal of Trades Unions Funds Protection Act, 1869, as herein stated.

duties of justices of the peace for such district, or of the police of such district, and elsewhere in Ireland, "The Petty Sessions (Ireland) Act, 1851," and any Act amending the same.

In Scotland the term " misdemeanor" means a $\operatorname{crim} \theta$ and offence.

The term "trade union" means such combination, whether temporary or permanent, for regulating the relations between workmen and masters, or between workmen and workmen, or between masters and masters, or for imposing restrictive conditions on the conduct of any trade or business as would, if this Act had not passed, have been deemed to have been an unlawful combination by reason of some one or more of its purposes being in restraint of trade: Provided that this Act shall not affect-

(1.) Any agreement between partners as to their own business ;

(2.) Any agreement between an employer and those employed by him as to such employment;

(3.) Any agreement in consideration of the sale of the good-will of a business or of instruction in any profession, trade, or handicraft.

\section{REPEAL.}

24. The Trades Unions Funds Protection Act, 1869, is hereby repealed.

Provided that this repeal shall not affect-

(1.) Anything duly done or suffered under the said Act:

(2.) Any right or privilege acquired or any liability incurred under the said Act:

(3.) Any penalty, forfeiture, or other punishment incurred in respect of any offence against the said Act:

(4.) The institution of any investigation or legal proceeding or any other remedy for ascertaining, enforcing, recovering, or imposing any such liability, penalty, forfeiture, or punishment as aforesaid. 


\section{SCHEDULES.}

\section{FIRST SCHEDULE.}

Of Matters to be provided for by the Rules of Trade Unions Registered under this Act.

1. The name of the trade union and place of meeting for the business of the trade union.

2. The whole of the objects for which the trade union is to be established, the purposes for which the funds thereof shall be applicable, and the conditions under which any member may become entitled to any benefit assured thereby, and the fines and forfeitures to be imposed on any member of such trade union.

3. The manner of making, altering, amending, and rescinding rules.

4. A provision for the appointment and removal of a general committee of management, of a trustee or trustees, treasurer, and other officers.

5. A provision for the investment of the funds, and for an annual or periodical audit of accounts.

6. The inspection of the books and names of members of the trade union by every person having an interest in the funds of the trade union.

\section{SECOND SCHEDULE.}

Maximum Fees.

$\begin{array}{llrrrr} & & & £ & s . & d . \\ \text { For registering trade union } & \cdot & 1 & 0 & 0 \\ \text { For registering alterations in rules } & \cdot & 0 & 10 & 0 \\ \text { For inspection of documents . } & \cdot & 0 & 2 & 6\end{array}$

(b) THE CONSPIRACY, AND PROTECTION OF PROPERTY ACT, 1875.

[38 \& 39 VICT. с. 86.]

1. This Act may be cited as the Conspiracy, and Pro short title. tection of Property Act, 1875.

19 Vict.

c. 63, s. 25 . 
Commencement of Act.

Amendment of law as to conspiracy in trade disputes.

2. This Act shall come into operation on the first day of September one thousand eight hundred and seventyfive.

\section{Conspiracy, and Protection of Property. .}

3. An agreement or combination by two or more persons to do or procure to be done any act in contemplation or furtherance of a trade dispute between employers and workmen shall not be indictable as a conspiracy if such act committed by one person would not be punishable as a crime.

Nothing in this section shall exempt from punishment any persons guilty of a conspiracy for which a punishment is awarded by any Act of Parliament.

Nothing in this section shall affect the law relating to riot, unlawful assembly, breach of the peace, or sedition, or any offence against the State or the Sovereign.

A crime for the purposes of this section means an offence punishable on indictment, or an offence which is punishable on summary conviction, and for the commission of which the offender is liable under the statute making the offence punishable to be imprisoned either absolutely or at the discretion of the court as an alternative for some other punishment.

Where a person is convicted of any such agreement or combination as aforesaid to do or procure to be done an act which is punishable only on summary conviction, and is sentenced to imprisonment, the imprisonment shall not exceed three months, or such longer time, if any, as may have been prescribed by the statute for the punishment of the said act when committed by one person.

Breach of contract by persons employed in supply of. gas or water.
4. Where a person employed by a municipal authority or by any company or contractor upon whom is imposed by Act of Parliament the duty, or who have otherwise assumed the duty of supplying any city, borough, town, or place, or any part thereof, with gas or water, wilfully and maliciously breaks a contract of service with that authority or company or contractor, knowing or having reasonable cause to believe that the probable consequences of his so doing, either alone or in combination with others, will be to deprive the inhabitants of that city, borough, town, place, or part, wholly or to a great 
extent of their supply of gas or water, he shall on conviction thereof by a court of summary jurisdiction or on indictment as hereinafter meniioned, be liable either to pay a penalty not exceeding twenty pounds or to be imprisoned for a term not exceeding three months, with or without hard labour.

Every such municipal authority, company, or contractor as is mentioned in this section shall cause to be posted up, at the gasworks or waterworks, as the case may be, belonging to such authority or company or contractor, a printed copy of this section in some conspicuous place where the same may be conveniently read by the persons employed, and as often as. such copy becomes defaced, obliterated, or destroyed, shall cause it to be renewed with all reasonable despatch.

If any municipal authority or company or contractor make default in complying with the provisions of this section in relation to such notice as aforesaid, they or he shall incur on summary conviction a penalty not exceeding five pounds for every day during which such default continues, and every person who unlawfully injures, defaces, or covers up any notice so posted up as aforesaid in pursuance of this Act, shall be liable on summary conviction to a penalty not exceeding forty shillings.

5. Where any person wilfully and maliciously breaks a contract of service or of hiring, knowing or having reasonable cause to believe that the probable consequences of his so doing, either alone or in combination with others, will be to endanger human life, or cause serious bodily injury, or to expose valuable property whether real or personal to destruction or serious injury, he shall on conviction thereof by a court of summary jurisdiction, or on indictment as herein-after mentioned, be liable either to pay a penalty not exceeding twenty pounds, or to be imprisoned for a term not exceeding three months, with or without hard labour.

\section{Miscellaneoús.}

6. Where a master, being legally liable to provide Penalty for his servant or apprentice necessary food, clothing, medical aid, or lodging, wilfully and without lawful

Breach of contract involving injury to persons or property. for neglect by master to provide 
food, clothing, etc., for servant or apprentice.

Penalty for intimidation or annoyance by violence or otherwise.

excuse refuses or neglects to provide the same, whereby the health of the servant or apprentice is or is likely to be seriously or permanently injured, he shall on summary conviction be liable either to pay a penalty not exceeding twenty pounds, or to be imprisoned for a term not exceeding six months, with or without hard labour.

7. Every person who, with a view to compel any other person to abstain from doing or to do any act which such other person has a legal right to do or abstain from doing, wrongfully and without legal authority,-

(1.) Uses violence to or intimidates such other person or his wife or children, or injures his property; or,

(2.) Persistently follows such other person about from place to place; or,

(3.) Hides any tools, clothes, or other property owned or used by such other person, or deprives him of or hinders him in the use thereof; or,

(4.) Watches or besets the house or other place where such other person resides, or works, or carries on business or happens to be, or the approach to such house or place; or,

(5.) Follows such other person with two or more other persons in a disorderly manner in or through any street or road,

shall, on conviction thereof by a court of summary jurisdiction, or on indictment as hereinafter mentioned, be liable either to pay a penalty not exceeding twenty pounds, or to be imprisoned for a term not exceeding three months, with or without hard labour.

Attending at or near the house or place where a person resides, or works, or carries on business, or happens to be, or the approach to such house or place, in order merely to obtain or communicate information, shall not be deemed a watching or besetting within the meaning of this section.

Reduction 8. Where in any Act relating to employers or workmen penalties. a pecuniary penalty is imposed in respect of any offence penalties. under such Act, and no power is given to reduce such penalty, the justices or court having jurisdiction in respect of such offence may, if they think it just so to do, impose by way of penalty in respect of such offence any 
sum not less than one-fourth of the penalty imposed by such Act.

\section{Legat Proceedings.}

9. Where a person is accused before a court of summary jurisdiction of any offence made punishable by this Act, and for which a penalty amounting to twenty pounds, or imprisonment, is imposed the accused may, on appearing before the court of summary jurisdiction, declare that he objects to being tried for such offence by a court of summary jurisdiction, and thereupon the court of summary jurisdiction may deal with the case in all respects as if the accused were charged with an indictable offence and not an offence punishable on summary conviction, and the offence may be prosecuted on indictment accordingly.

10. Every offence under this Act which is made punishable on conviction by a court of summary jurisdiction or on summary conviction, and every penalty under this Act recoverable on summary conviction, may be prosecuted and recovered in manner provided by the Summary Jurisdiction Act.

11. Provided, that upon the hearing and determining of any indictment or information under sections four, five, and six of this Act, the respective parties to the contract of service, their husbands or wives, shall be deemed and considered as competent witnesses.

12. In England or Ireland, if any party feels aggrieved by any conviction made by a court of summary jurisdiction on determining any information under this Act, the party so aggrieved may appeal therefrom, subject to the conditions and regulations following:

(1.) The appeal shall be made to some court of general or quarter sessions for the county or place in which the cause of appeal has arisen, holden not less than fifteen days and not more than four months after the decision of the court from which the appeal is made:

(2.) The appellant shall, within seven days after the cause of appeal has arisen, give notice to the other party and to the court of summary

Power for offender under this Act to be tried on indictment and not by court of summary jurisdiction.

Proceedings before court of summary jurisdiction.

Regulations as to evidence.

Appeal to quarter sessions. 
jurisdiction of his intention to appeal, and of the ground thereof:

(3.) The appellant shall immediately after such notice enter into a recognizance before a justice of the peace, with or without sureties, conditioned personally to try such appeal and to abide the judgment of the court thereon, and to pay such costs as may be awarded by the court:

(4.) Where the appellant is in custody the justice may, if he think fit, on the appellant entering into such recognizance as aforesaid, release him from custody:

(5.) The court of appeal may adjourn the appeal, and upon the hearing thereof they may confirm, reverse, or modify the decision of the court of summary jurisdiction, or remit the matter to the court of summary jurisdiction with the opinion of the court of appeal thereon, or make such other order in the matter as the court thinks just, and if the matter be remitted to the court of summary jurisdiction the said last-mentioned court shall thereupon rehear and decide the information in accordance with the opinion of the said court of appeal. The court of appeal may also make such order as to costs to be paid by either party as the court thinks just.

\section{Definitions.}

General

defini-

tions :

"The

Summary

Jurisdiction Act."

" Court of summary jurisdiction."
13. In this Act,-

The expression "the Summary Jurisdiction Act" means the Act of the session of the eleventh and twelfth years of the reign of Her present Majesty, chapter fortythree, intituled "An Act to facilitate the performance of the duties of justices of the peace out of sessions within England and Wales with respect to summary convictions and orders," inclusive of any Acts amending the same; and

The expression "court of summary jurisdiction" means-

(1.) As respects the city of London, the Lord Mayor or any alderman of the said city sitting at the Mansion House or Guildhall justice room; and 
(2.) As respects any police court division in the Metropolitan police district, any Metropolitan police magistrate sitting at the police court for that division; and

(3.) As respects any city, town, liberty, borough, place, or district for which a stipendiary magistrate is for the time being acting, such stipendiary magistrate sitting at a police court or other place appointed in that behalf; and

(4.) Elsewhere, any justice or justices of the peace to whom jurisdiction is given by the Summary Jurisdiction Act: Provided that, as respects any case within the cognizance of such justice or justices as last aforesaid, an information under this Act shall be heard and determined by two or more justices of the peace in petty sessions sitting at $\operatorname{som} \theta$ place appointed for holding petty sessions.

Nothing in this section contained shall restrict the jurisdiction of the Lord Mayor or any alderman of the city of London, or of any metropolitan police or stipendiary magistrate, in respect of any act or jurisdiction which may now be done or exercised by him out of court.

14. The expression "municipal authority" in this Act means any of the following authorities, that is to say, the Metropolitan Board of Works, the Common Council of the city of London, the Commissioners of Sewers of the city of London, the town council of any borough for the time being subject to the Act of the session of the fifth and sixth years of the reign of King William the Fourth, chapter seventy-six, intituled "An Act to provide for the Regulation of Municipal Corporations in England and Wales," and any Act amending the same, any commissioners, trustees, or other persons invested by any local Act of Parliament with powers of improving, cleansing, lighting, or paving any town, and any local board.

Any municipal authority or company or contractor who has obtained authority by or in pursuance of any general or local Act of Parliament to supply the streets of any city, borough, town, or place, or of any part thereof, with gas, or which is required by or in pursuance of any general or local Act of Parliament to 
supply water on demand to the inhabitants of any city, borough, town, or place, or any part thereof, shall for the purposes of this Act be deemed to be a municipal authority or company or contractor upon whom is imposed by Act of Parliament the duty of supplying such city, borough, town, or place, or part thereof, with gas or water.

"Maliciously" in this Act construed as in

Malicious Injuries to Property Act.

15. The word "maliciously" used in reference to any offence under this Act shall be construed in the same manner as it is required by the fifty-eighth section of the Act relating to malicious injuries to property, that is to say, the Act of the session of the twenty-fourth and twenty-fifth years of the reign of Her present Majesty, chapter ninety-seven, to be construed in reference to any offence cimmitted under such last-mentioned Act.

\section{Saving Clause.}

Saving as to sea service.

Repeal of Acts.

16. Nothing in this Act shall apply to seamen or to apprentices to the sea service.

\section{Repeal.}

17. On and after the commencement of this Act, there shall be repealed:-

I. The Act of the session of the thirty-fourth and thirty-fifth years of the reign of Her present Majesty, chapter thirty-two, intituled "An Act to amend the Criminal Law relating to violence, threats, and molestation;" and

II. "The Master and Servant Act, 1867," and the enactments specified in the First Schedule to that Act, with the exceptions following as to the enactments in such Schedule; (that is to say,)

(1.) Except so much of sections one and two of the Act passed in the thirty-third year of the reign of King George the Third, chapter fiftyfive, intituled "An Act to authorise justices of the peace to impose fines upon constables, overseers, and other peace or parish officers for neglect of duty, and on masters of apprentices for ill-usage of such their apprentice; and also to make provision for the execution of warrants of distress granted by magistrates," as 
relates to constables, overseers, and other peace or parish officers; and

(2.) Except so much of sections five and six of an Act passed in the fifty-ninth year of the reign of King George the Third, chapter ninety-two, intituled "An Act to enable justices of the peace in Ireland to act as such, in certain cases, out of the limits of the counties in which they actually are; to make provision for the execution of warrants of distress granted by them; and to authorise them to impose fines upon constables and other officers for neglect of duty, and on masters for illusage of their apprentices," as relates to constables and other peace or parish officers; and

(3.) Except the Act of the session of the fifth and sixth years of the reign of Her present Majesty, chapter seven, intituled "An Act to explain the Acts for the better regulation of certain apprentices;" and

(4.) Except subsections one, two, three, and five of sections sixteen of "The Summary Jurisdiction (Ireland) Act, 1851," relating to certain disputes between employers and the persons employed by them; and

III. Also there shall be repealed the following enactments making breaches of contract criminal, and relating to the recovery of wages by summary procedure; (that is to say,)

(a.) An Act passed in the fifth year of the reign of Queen Elizabeth, chapter four, and intituled "An Act touching dyvers orders for artificers, labourers, servantes of husbandrye, and apprentices;" and

(b.) So much of section two of an Act passed in the twelfth year of King George the First, chapter thirty-four, and intituled "An Act to prevent unlawful combination of workmen employed in the woollen manufactures, and for better payment of their wages," as relates to departing from service and quitting or returning work before it is finished; and

(c.) Section twenty of an Act passed in the fifth 
year of King George the Third, chapter fiftyone, the title of which begins with the words "An Act for repealing several laws relating to the manufacture of woollen cloth in the county of York," and ends with the words "for preserving the credit of the said manufacture at the foreign market; " and

(d.) An Act passed in the nineteenth year of King George the Third, chapter forty-nine, and intituled "An Act to prevent abuses in the payment of wages to persons employed in the bone and thread lace manufactory;" and

(e.) Sections eighteen and twenty-three of an Act passed in the session of the third and fourth years of Her present Majesty, chapter ninety-one, intituled "An Act for the more effectual prevention of frauds and abuses committed by weavers, sewers, and other persons employed in the linen, hempen, union, cotton, silk, and woollen manufactures in Ireland, and for the better payment of their wages, for one year, and from thence to the end of the next session of Parliament;" and

(f.) Section seventeen of an Act passed in the session of the sixth and seventh years of Her present Majesty, chapter forty, the title of which begins with the words "An Act to amend the Laws," and ends with the words "workmen engaged therein; " and

(g.) Section seven of an Act passed in the session of the eighth and ninth years of Her present Majesty, chapter one hundred and twentyeight, and intituled "An Act to make further regulations respecting the tickets of work to be delivered to silk weavers in certain cases."

\section{Provided that,-}

(1.) Any order for wages or further sum of compensation in addition to wages made in pursuance of section sixteen of "The Summary Jurisdiction (Ireland) Act, 1851," may be enforced in like manner as if it were an order made by a court of summary jurisdiction in pursuance of the 
Employers and Workmen Act, 1875, and not otherwise; and

(2.) The repeal enacted by this section shall not affect-

(a.) Anything duly done or suffered, or any right or liability acquired or incurred under any enactment hereby repealed; or

(b.) Any penalty, forfeiture, or punishment incurred in respect of any offence committed against any enactment hereby repealed; or

(c.) Any investigation, legal proceeding, or remedy in respect of any such right, liability, penalty, forfeiture, or punishment as aforesaid; and any such investigation, legal proceeding, and remedy may be carried on as if this Act had not passed.

Application of Act to Scotland.

18. This Act shall extend to Scotland, with the modifications following; that is to say,

(1.) The expression "municipal authority" means the town council of any royal or parliamentary burgh, or the commissioners of police of any burgh, town, or populous place under the provisions of the General Police and Improvement (Scotland) Act, 1862, or any local authority under the provisions of the Public Health (Scotland) Act, 1867:

(2.) The expression "The Summary Jurisdiction Act" means the Summary Procedure Act, 1864, and any Acts amending the same:

(3.) The expression "the court of summary jurisdiction" means the sheriff of the county or any one of his substitutes.

19. In Scotland the following provisions shall have effect in regard to the prosecution of offences, recovery of penalties, and making of orders under this Act:

(1.) Every offence under this Act shall be prosecuted, every penalty recovered, and every order made at the instance of the Lord Advocate, or of the Procurator Fiscal of the sheriff court:

(2.) The proceedings may be on indictment in the Court of Justiciary in Edinburgh or on circuit

Recovery of penalties, etc., in Scotland. tion to Scotland. Definitions.

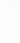


or in a sheriff court, or may be taken summarily in the sheriff court under the provisions of the Summary Procedure Act, 1864:

(3.) Every person found liable on conviction to pay any penalty under this Act shall be liable, in default of payment within a time to be fixed in the conviction, to be imprisoned for a term, to be also fixed therein, not exceeding two months, or until such penalty shall be sooner paid, and the conviction and warrant may be in the form of No. 3 of Schedule K. of the Summary Procedure Act, 1864:

(4.) In Scotland all penalties imposed in pursuance of this Act shall be paid to the clerk of the court imposing them, and shall by him be accounted for and paid to the Queen's and Lord Treasurer's Remembrancer, and be carried to the Consolidated Fund.

Appeal in Scotland as prescribed by 20 Geo. 2, c. 43.
Application to Ireland.

20. In Scotland it shall be competent to any person to appeal against any order or conviction under this Act to the next circuit Court of Justiciary, or where there are no circuit courts to the High Court of Justiciary at Edinburgh, in the manner prescribed by and under the rules, limitations, conditions, and restrictions contained in the Act passed in the twentieth year of the reign of His Majesty King George the Second, chapter forty-three, in regard to appeals to circuit courts in matters criminal, as the same may be altered or amended by any Acts of Parliament for the time being in force.

\section{Application of Ačt to Ireland.}

21. This Act shall extend to Ireland, with the modifications following; that is to say,

The expression "The Summary Jurisdiction Act" shall be construed to mean, as regards the police district of Dublin metropolis, the Acts regulating the powers and duties of justices of the peace for such district; and elsewhere in Ireland, the Petty Sessions (Ireland) Act, 1851, and any Acts amending the same:

The expression " court of summary jurisdiction" shall be construed to mean any justice or justices of the 
peace, or other magistrate to whom jurisdiction is given by the Summary Jurisdiction Act:

The court of summary jurisdiction, when hearing and determining complaints under this Act, shall in the police district of Dublin metropolis be constituted of one or more of the divisional justices of the said district, and elsewhere in Ireland of two or more justices of the peace in petty sessions sitting at a place appointed for holding petty sessions:

The expression "municipal authority" shall be construed to mean the town council of any borough for the time being, subject to the Act of the session of the third and fourth years of the reign of Her present Majesty, chapter one hundred and eight, entitled "An Act for the Regulation of Municipal Corporations in Ireland," and any commissioners invested by any general or local Act of Parliament, with power of improving, cleansing, lighting, or paving any town or township.

(c) THE TRADE UNION ACT (1871) AMENDMENT ACT, 1876.

[39 \& 40 VICT. c. 22.]

1. This Act and the Trade Union Act, 1871, hereinafter termed the principal Act, shall be construed as one Act, and may be cited together as the "Trade Union Acts, 1871 and 1876," and this Act may be cited separately as the "Trade Union Act Amendrnent Act, 1876."

2. Notwithstanding anything in section five of the Trade principal Act contained, a trade union, whether registered or unregistered, which insures or pays money on the death of a child under ten years of age shall be deemed to be within the provisions of section twentyeight of the Friendly Societies Act, 1875.

Construction and short title. unions to be within 8. 28 of Friendly Societies Act, 1875 . 
Amendment of s. 8 of principal Act.

Provision in case of absence, etc., of trustee.
Jurisdiction in offences.
3. Whereas by section eight of the principal Act it is enacted that "the real or personal estate of any branch of a trade union shall be vested in the trustees of such branch:" The said section shall be read and construed as if immediately after the hereinbefore recited words there were inserted the words "or of the trustees of the trade union, if the rules of the trade union so provide."

4. When any person, being or having been a trustee of a trade union or of any branch of a trade union, and whether appointed before or after the legal establishment thereof, in whose name any stock belonging to such union or branch transferable at the Bank of England or Bank of Ireland is standing, either jointly with another or others, or solely, is absent from Great Britain or Ireland respectively, or becomes bankrupt, or files any petition, or executes any deed for liquidation of his affairs by assignment or arrangement, or for composition with his creditors, or becomes a lunatic, or is dead, or has been removed from his office of trustee, or if it be unknown whether such person is living or dead, the registrar, on application in writing from the secretary and three members of the union or branch, and on proof satisfactory to him, may direct the transfer of the stock into the names of any other persons as trustees for the union or branch; and such transfer shall be made by the surviving or continuing trustees, and if there be no such trustee, or if such trustees refuse or be unable to make such transfer, and the registrar so direct, then by the Accountant-General or Deputy or Assistant Accountant-General of the Bank of England or Bank of Ireland, as the case may be; and the Governors and Companies of the Bank of England and Bank of Ireland respectively are hereby indemnified for anything done by them or any of their officers in pursuance of this provision against any claim or demand of any person injuriously affected thereby.

5 . The jurisdiction conferred in the case of certain offences by section twelve of the principal Act upon the court of summary jurisdiction for the place in which the registered office of a trade union is situate may be exercised either by that court or by the court of 
summary jurisdiction for the place where the offence has been committed.

6. Trade unions carrying or intending to carry on business in more than one country shall be registered in the country in which their registered office is situate; but copies of the rules of such unions, and of all amendments of the same, shall, when registered, be sent to the registrar of each of the other countries, to be recorded by him, and until such rules be so recorded the union shall not be entitled to any of the privileges of this Act or the principal Act, in the country in which such rules have not been recorded, and until such amendments of rules be recorded the same shall not take effect in such country.

In this section "country" means England, Scotland, or Ireland.

7. Whereas by the "Life Assurance Companies Act, Life 1870 " it is provided that the said Act shall not apply, to societies registered under the Acts relating to Friendly Societies: The said Act (or the amending Acts) shall not apply nor be deemed to have applied to trade unions registered or to be registered under the principal Act.

8. No certificate of registration of a trade union shall be withdrawn or cancelled otherwise than by the chief registrar of Friendly Societies, or in the case of trade unions registered and doing business exclusively in Scotland or Ireland, by the assistant registrar for Scotland or Ireland, and in the following cases:

(1.) At the request of the trade union to be evidenced in such manner as such chief or assistant registrar shall from time to time direct:

(2.) On proof to his satisfaction that a certificate of registration has been obtained by fraud or mistake, or that the registration of the trade union has become void under section six of the Trade Union Act, 1871, or that such trade union has wilfully and after notice from a registrar whom it may concern, violated any of the provisions of the Trade Union Acts, or has ceased to exist.

Not less than two months previous notice in writing,

Assurance

Com-

panies

Acts not to apply to regi:tered unions.

Withdrawal or cancelling of certificate. 
specifying briefly the ground of any proposed withdrawal or cancelling of certificate (unless where the same is shown to have become void as aforesaid, in which case it shall be the duty of the chief or assistant registrar to cancel the same forthwith) shall be given by the chief or assistant registrar to a trade union before the certificate of registration of the same can be withdrawn or cancelled (except at its request).

A trade union whose certificate of registration has been withdrawn or cancelled shall, from the time of such withdrawal or cancelling, absolutely cease to enjoy as such the privileges of a registered trade union, but without prejudice to any liability actually incurred by such trade union, which may be enforced against the same as if such withdrawal or cancelling had not taken' place.

Membership of Minors.

Nomination.

Change of name.
9. A person under the age of twenty-one, but above the age of sixteen, may be a member of a trade union, unless provision be made in the rules thereof to the contrary, and may, subject to the rules of the trade union, enjoy all the rights of a member except as herein provided, and execute all instruments and give all acquittances necessary to be executed or given under the rules, but shall not be a member of the committee of management, trustee, or treasurer of the trade union.

10. A member of a trade union not being under the age of sixteen years may, by writing under his hand, delivered at, or sent to, the registered office of the trade union, nominate any person not being an officer or serrvant of the trade union (unless such officer or servant is the husband, wife, father, mother, child, brother, sister, nephew, or niece of the nominator), to whom any moneys payable on the death of such member not exceeding fifty pounds shall be paid at his decease, and may from time to time revoke or vary such nomination by a writing under his hand similarly delivered or sent; and on receiving satisfactory proof of the death of a nominator, the trade union shall pay to the nominee the amount due to the deceased member not exceeding the sum aforesaid.

11. A trade union may, with the approval in writing of the chief registrar of Friendly Societies, or in the 
case of trade unions registered and doing business exclusively in Scotland or Ireland, of the assistant registrar for Scotland or Ireland respectively, change its name hy the consent of not less than two thirds of the total number of members.

No change of name shall affect any right or obligation of the trade union or of any member thereof, and any pending legal proceedings may be continued by or against the trustees of the trade union or any other officer: who may sue or be sued on behalf of such trade union notwithstanding its new name.

12. Any two or more trade unions may, by the con- Amalgasent of not less than two thirds of the members of each mation. or every such trade union, become amalgamated together as one trade union, with or without any dissolution or division of the funds of such trade unions, or either or any of them; but no amalgamation shall prejudice any right of a creditor of either or any union party thereto.

13. Notice in writing of every change of name or amalgamation signed, in the case of a change of name, by seven members, and countersigned by the secretary of the trade union changing its name, and accompanied by a statutory declaration by such secretary that the provisions of this Act in respect of changes of name have been complied with, and in the case of an amalgamation signed by seven members, and countersigned by the secretary of each or every union party thereto, and accompanied by a statutory declaration by each or every: such secretary that the provisions of this Act in respect of amalgamations have been complied with, shall be sent to the central office established by the Friendly Societies Act, 1875, and registered there, and until such change of name or amalgamation is so registered the same shall not take effect.

14. The rules of every trade union shall provide for the manner of dissolving the same, and notice of every Dissolution. dissolution of a trade union under the hand of the secretary and seven members of the same, shall be sent within fourteen days thereafter to the central office hereinbefore mentioned, or, in the case of trade unions registered and doing business exclusively in Scotland

Registration of changes of names and amalgamations. 
or Ireland, to the assistant registrar for Scotland or Ireland respectively, and shall be registered by them: Provided that the rules of any trade union registered before the passing of this Act shall not be invalidated by the absence of a provision for dissolution.

Penalty for failure to give notice.

Definition of "trade union" altered.
15. A trade union which fails to give any notice or send any document which it is required by this Act to give or send, and every officer or other person bound by the rules thereof to give or send the same, or if there be no such officer, then every member of the committee of management of the union, unless proved to have been ignorant of, or to have attempted to prevent the omission to give or send the same, is liable to a penalty of not less than one pound and not more than five pounds, recoverable at the suit of the chief or any assistant registrar of Friendly Societies, or of any person aggrieved, and to an additional penalty of the like amount for each week during which the omission continues.

16. So much of section twenty-three of the principal Act as defines the term trade union, except the proviso qualifying such definition, is hereby repealed, and in lieu thereof be it enacted as follows :

The term "trade union" means any combination, whether temporary or permanent, for regulating the relations between workmen and masters, or between workmen and workmen, or between masters and masters, or for imposing restrictive conditions on the conduct of any trade or business, whether such combination would or would not, if the principal Act had not been passed, have been deemed to have been an unlawful combination by reason of some one or more of its purposes being in restraint of trade. 


\section{(d) THE TRADE UNION (PROVIDENT FUNDS) ACT, 1893.}

[56 \& 57 Vicт. с. 2.]

1. A trade union duly registered under the Trade Provident Union Acts, 1871 and 1876, shall be entitled to exemp- funds of tion from income tax chargeable under Schedules A., trade C., and D. of any Acts for granting duties of income tax be exempt in respect of the interest and dividends of the trade from union applicable and applied solely for the purpose of provident benefits.

Provided always that the exemption shall not extend to any trade union by the rules of which the amount assured to any member, or person nominated by or claiming under him, shall exceed the total sum of two hundred pounds, or the amount of any annuity granted to any member, or person nominated by him, shall exceed the sum of thirty pounds per annum.

2. The exemption shall be claimed and allowed in the same manner as is prescribed by law in the case of income applicable and applied to charitable purposes.

3. In this Act the expression "provident benefits" means and includes any payment made to a member during sickness or incapacity from personal injury, or while out of work; or to an aged member by way of superannuation, or to a member who has met with an accident or has lost his tools by fire or theft, or a payment in discharge or aid of funeral expenses on the death of a member or the wife of a member, or as provision for the children of the deceased member, where the payment in respect whereof exemption is claimed is a payment expressly authorised by the registered rules of the trade union claiming the exemption.

4. This Act may be cited as the Trade Union (Pro- Short vident Funds) Act, 1893.

Mode of claiming exemption.

Definition of "provident benefits." 


\section{(e) THE TRADE DISPUTES ACT, 1906.}

[6 EDw. 7, c. 47.]

Amendment of law of conspiracy in the case of trade disputes. $38 \& 39$ Vict. c. 86
Peaceful picketing.
Removal of

liability

for interfering

with another person's business, \&c.

Prohibition of actions of tort against trade unions. 34 \& 35 provided for by the Trade Union Act, 1871, section nine,

1. The following paragraph shall be added as a new paragraph after the first paragraph of section three of the Conspiracy and Protection of Property Act, 1875:-

"An act done in pursuance of an agreement or combination by two or more persons shall, if done in contemplation or furtherance of a trade dispute, not be actionable unless the act, if done without any' such agreement or combination, would be actionable."

2.-(1) It shall be lawful for one or more persons, acting on their own behalf or on behalf of a trade union or of an individual employer or firm in contemplation or furtherance of a trade dispute, to attend at or near a house or place where a person resides or works or carries on business or happens to be, if they so attend merely for the purpose of peacefully obtaining or communicating information, or of peacefully persuading any person to work or abstain from working.

(2) Section seven of the Conspiracy and Protection of Property Act, 1875, is hereby repealed from " attending at or near" to the end of the section.

3. An act done by a person in contemplation or furtherance of a trade dispute shall not be actionable on the ground only that it induces some other person to break a contract of employment or that it is an interference with the trade, business, or employment of some other person, or with the right of some other person to dispose of his capital or his labour as he wills.

4.-(1) An action against a trade union, whether of workmen or masters, or against any members or officials thereof on behalf of themselves and all other members of the trade union in respect of any tortious act alleged to have been committed by or on behalf of the trade union, shall not be entertained by any court.

(2) Nothing in this section shall affect the liability of the trustees of a trade union to be sued in the events vict.c. 31. except in respect of any tortious act committed by or 
on behalf of the union in contemplation or in furtherance of a trade dispute.

5.-(1) This Act may be cited as the Trade Disputes Act, 1906, and the Trade Union Acts, 1871 and 1876, and this Act may be cited together as the Trade Union Short title and construction. Acts, 1871 to 1906.

(2) In this Act the expression "trade union" has the same meaning as in the Trade Union Acts, 1871 and 1876 , and shall include any combination as therein defined, notwithstanding that such combination may be the branch of a trade union.

(3) In this Act and in the Conspiracy and Protection of Property Act, 1875, the expression "trade dispute " means any dispute between employers and workmen, or between workmen and workmen, which is connected with the employment or non-employment or the terms of the employment, or with the conditions of labour, of any person, and the expression "workmen " means all persons employed in trade or industry, whether or not in the employment of the employer with whom a trade dispute arises; and, in section three of the lastmentioned Act, the words " between employers and workmen " shall be repealed. 


\section{APPENDIX II.}

\section{REGULATIONS.}

Regulations dated November 1, 1876, made by the Secretary of State as to the Registration of Trade Unions as amended by Regulations made by the Seoretary of State, April 29, 1890, and by the Secretary for Scotland, May 8, $1890(a)$.

Trade Union Acts, 1871 (b) \& 1876 (c).

(1.) In the following Regulations and Forms the terms " chief registrar" and "assistant registrar" mean respectively the chief registrar and assistant registrar of Friendly Societies, and the term "central office" means the central office established under the Friendly Societies Act, $1875(d)$.

(2.) The registrar shall not register a trade union under a name identical with that of any other existing trade union known to him, whether registered or not registered, or so nearly resembling such name as to be likely to deceive the members or the public.

(3.) Upon an application for the registration of a trade union which is already in operation, the registrar, if he has reason to believe that the applicants have not been duly authorised by such trade union to make the same, may, for the purpose of ascertaining the fact, require from the applicants such evidence as may seem to him necessary.

(4.) Application for registry of a trade union shall be made in Form A. subjoined to these regulations, and shall be accompanied by two printed copies of the rules, marked and signed, as mentioned in the said form.

(a) The amending Regula. tions which were made under the Acts of 1871 and 1876 and the Secretary for Scotland Act, 1887, are printed at length in
Statutory Rules and Orders, 1890, p. 1015.

(b) $34 \& 35$ Vict. c. 31.

(c) $39 \& 40$ Vict. c. 22.

(d) 38 \& 39 Vict. c. 60. 
(5.) The certificate of registry of a trade union shall be in Form B. subjoined to these Regulations.

(6.) An alteration of the rules of a trade union may be either-

(a.) A partial alteration, consisting of the addition of a new rule or part of a rule or rules to the existing rules, or of the substitution of a new rule or part of a rule or rules for any of the existing rules, or of a rescission of any of the existing rules or any part thereof without any substitution or of more than one or all of those modes; or,

(b.) A complete alteration consisting of the substitution of an entire set of rules for the existing set of rules.

(7.) An application for the registration of a partial alteration of rules must be made by seven members of the trade union, and must be made in the Form C. annexed hereto, and must be accompanied by a statutory declaration in Form D. hereto annexed, and by a printed copy of the existing rules, and by the following documents :-

(a.) If the partial alteration consists of the addition or substitution of a new rule or part of a rule or rules, two copies of such rule or part of a rule or rules, each copy being marked $O$. and signed by each of the applicants.

(b.) If the partial alteration consists of the rescission of any of the rules without any substitu. tion, two copies of the resolution for such rescission, each copy being marked 0 . and signed by each of the applicants.

The Registrar, before registering the partial alteration of rules, shall ascertain that the rules of the trade union, if altered in accordance with the proposed partial alteration, will provide for all the matters required by the above-mentioned Acts to be provided for by the rules of a registered trade union.

(8.) The certificate of registry of a partial alteration shall be in Form E. annexed hereto, and shall be delivered to the applicants, attached to one of the copies of the new rule or rules, or, when the alteration consists of rescission merely, attached to the old set of rules.

(9.) An application for the registration of a com-

T.U. 
plete alteration of rules shall be made by seven members of the trade union, and shall be in Form F. annexed hereto, and must be accompanied by a statutory declaration in Form D. annexed hereto, and by a printed copy of the existing rules and by two printed copies of the new rules, each copy being marked $P$. and signed by each of the applicants; and the registrar before registering the new set of rules shall ascertain that it provides for all matters which, by the above-mentioned Acts, are to be provided for by the rules of a registered trade union.

(10.) The certificate of registry of a complete alteration of rules shall be in Form G. annexed hereto, and shall be delivered to the applicants attached to one of the copies of the new set of rules.

\section{Recording of Rules already Registered.}

(11.) An application to record in one country rules or amendments of rules registered in another shall bo made by the secretary or other officer of the trade union in Form H. or I. hereto annexed, and shall be accompanied by a copy of such rules or amendments duly authenticated.

Withdrawal or Cancelling of Certificate of Registration.

(12.) Every request by a trade union for withdrawal or cancelling of its certificate of registration shall be sent to the chief registrar or assistant registrar for Scotland or for Ireland, as the case may require, in Form J. annexed hereto.

(13.) Notice before withdrawal or cancelling of certificate, where required, shall be in Form K. annexed hereto.

(14.) The withdrawal or cancelling of certificate shall be in Form L. annexed hereto.

\section{Registered Office (a).}

(15.) Notice of the situation of the registered office of a trade union, and of any change therein, shall be given to the Registrar in Form M. annexed hereto. 
(15A.) (a) The removal of the registered office of a trade union from one country within the meaning of section 6 of the Trade Union Act Amendment Act, 1876, to another shall not render it necessary to re-register the trade union in the country in which its new registered office is situate.

(15в.) (a). All matters requiring registry shall be registered in and returns and notices sent to the registrar of the country in which the registered office of a trade union is for the time being situate; copies of matters requiring registry being forwarded for recording to the registrar of each of the other countries in which it is carrying or intending to carry on business.

\section{Change of Name.}

(16.) The application for approval, and notice of change of name of a trade union shall be in Form N. annexed hereto, and shall be sent in duplicate, accompanied by a statutory declaration in Form O. annexed hereto, to the chief registrar, or, in the case of trade unions registered and doing business exclusively in Scotland or Ireland, to the assistant registrar for Scotland or Ireland, as the case may require. The chief or assistant registrar, before approving the change of name, shall ascertain that the new name is not identical with that of any existing trade union known to him, or so nearly resembling the same as to be calculated to deceive; and if the change of name be approved, the word " approved" shall be written at the foot or end of each copy of the application, and the same shall be signed by the chief registrar or by such assistant registrar as the case may require, and shall be transmitted by him to the central office for registry.

\section{Transfer of Stock.}

(17.) Every application to the registrar to direct a transfer of stock shall follow, as near as may be, Form P. annexed hereto, and shall be accompanied by

(a) Regulations $15 . \mathrm{A}$ and $15 \mathrm{~B}$ were alded by the: Regulation of 1890 . 
a statutory declaration in Form Q. annexed hereto, or as near thereto as the fact admit, and by the certificate of the stock in respect of which the application is made.

(18.) Before making the application, the trade union shall submit to the registrar for examination a draft copy, on foolscap paper, written on one side only of the proposed application and declaration.

(19.) The registrar, before directing the transfer, may require further proof of any statement in the application.

(20.) The registrar shall give a direction in Form $R$. annexed hereto, so framed in each case as to suit the particular circumstances, and shall register the same and deliver the same to the applicants endorsed with the word "registered," and duly authenticated.

\section{Dissolution.}

(21.) When a trade union is dissolved, notice of the dissolution shall be given to the central office, or in the case of trade unions registered and doing business exclusively in Scotland or Ireland, to the assistant registrar for Scotland or Ireland, as the case may require, in duplicate in Form S. annexed hereto, and the central office or assistant registrar shall return one copy to the trade union, endorsed with the word "registered," and duly authenticated.

\section{Amalgamation.}

(22.) Where two or more trade unions become amalgamated together, notice shall be given to the central office in duplicate in Form T. annexed hereto, accompanied by statutory declarations from each such trade union in Form U. annexed hereto, and the central office shall return to the amalgamated trade union one copy of the notice, endorsed with the word "registered," and duly authenticated.

\section{Nominations.}

(23.) Every registered trade union shall keep a record or register of all nominations made by the members, and of all revocations and variations of the same, and for the recording or registering of every such nomination, revocation, or variation the rules of the trade union 
may require the member nominating to pay a sum not exceeding threepence.

\section{Fees.}

(24.) The following fees shall be payable under the Acts :-

$\stackrel{\mathfrak{E}}{s}, d$.

For the certificate of registry of a trade

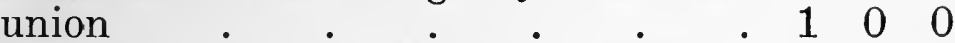

For the certificate of registry of an alteration of rules . $. \quad . \quad .0100$

For the certificate of registry of a change of name . $\quad . \quad . \quad . \quad . \quad .00100$ For a direction to transfer stock . 100 For registry of notice of a dissolution . $\begin{array}{llll}0 & 2 & 6\end{array}$ For registry of amalgamation . . . 0100 For every document required to be authenticated by the registrar, not $\begin{array}{llllll}\text { chargeable with any other fee } & \cdot & 0 & 0 & 6\end{array}$

For every inspection on the same day of documents (whether one or more), in custody of the Registrar, relating to one and the same trade union . .

For every copy or extract of any document in the custody of the Registrar, not exceeding 216 words $1 s$., and if exceeding that number $4 d$. per folio of 72 words, in addition to the fee for authentication.

No fee is payable for the recording of rules or decuments already registered in another country, or for the registry or recording of-

The cancelling or withdrawal of certificate of registry.

Any notice of change of office.

Any document or copy of document supplied to a public department.

Any document in respect of which a fee is already chargeable under or by virtue of the Act and of any other statute.

The chief registrar may also dispense with the fee for inspection of documents in cases where he may consider it for the public interest to do so. 
Authentication of Doouments by Registrar.

(25.) Every document under the Trade Union Acts, 1871. (a) and $1876(b)$, bearing the seal of the central office, or the signature of the chief registrar or the assistant registrar for Scotland or Ireland, as the case may require, shall be deemed to be duly authenticated for the purposes of the said Acts and the regulations made thereunder.
(a) $34 \& 35$ Vict. c. 31.
(b) $39 \& 40$ Vict. c. 22 . 


\section{APPENDIX III.}

FORMS.

For societies registered in Scotland the address " 43 , Now Register House, Edinburgh," and in Ireland " 9 , Upper Ormond Quay, Dublin," will be substituted in the following forms for " 28, Abingdon Street, Westminster."

\section{Form A.-Reg. 4.}

Trade Union Acts, 1871 and 1876, 34 \& 35 Vict. c. 31, and $39 \& 40$ Vict. c. 22.

\section{Application for Registry of Trade Union.}

1. This application is made by the seven persons whose names are subscribed at the foot hereof.

2. The name under which it is proposed that the trade union on behalf of which this application is made shall be registered is , as set forth in Rule No.

To the best of our belief there is no other existing trade union, whether registered or not registered, the name of which is identical with the proposed name or so nearly resembles the same as to cause confusion.

3. The place of meeting for the business of the * and the office to which all communications and notices may b'

addressed, is at was set forth in Rule No.
4. The* ${ }^{*}$ way of

5. The whole of the objects for which the* is estabunion. lished and the purposes for which the funds thereof are applicable are set forth in Rule No.

6. The conditions under which members may become entitled to benefits assured are set forth in Rule No.

7. The fines and forfeitures to be imposed on members are * Name of trade union.

* Name of trade union. set forth in Rule No.

8. The manner of making, altering, amending, and rescinding rules is set forth in Rule No.

9. The provision for the appointment and removal of a general committee of management, of trustee or trustees, treasurer, and other officers, is set forth in Rule No.

10. The provision for the investment of funds and for the periodical audit of accounts is set forth in Rule No.

11. The provision for the inspection of the books and names of the members by every person having an interest in the funds is set forth in Rule No.

12. The provision for the manner of dissolving the trade union is set forth in Rule No. 
* This

will only

be neces-

sary in

cases

where the

trade

union has

been in

operation

more than

a year pre-

vious to

the date of

the appli-

cation.

$\dagger$ Name

of 'trade

union.

\pm This

date will

be fixed

by the

Registrar.

$\S$ This

will only

be neces-

sary where

the trade

union has

been in

operation

before the

date of the

applica-

tion.
13. Accompanying this application are sent-

1. Two printed copies, each marked A., of the rules.

2. A list, marked B., of the titles and names of the officers.

3. A general statement, marked C.* showing-

(a.) The assets and liabilities of the $\dagger$ at the date up to which the statement is made out.

(b.) The receipts and expenditure of $\dagger$ during the year preceding the date $\neq$ up to which the statement is made out, such expenditure being set forth under separate heads corresponding to the several objects of the Trade Union.

14. §We have been duly authorised by the trade union to make this application on its behalf, such authorisation consisting of

$\begin{array}{ll}\text { (Signed) } & 1 . \\ & 2 . \\ & 3 . \\ & 4 . \\ & 5 . \\ & 6 . \\ & 7 .\end{array}$

day of

18

In paragraph 14 must be stated whether the authority to make this application was given by a "resolution of a general meeting of the trade union," or, if not, in what other way it was given.

The two copies of rules must be signed by the seven members signing this application.

The application should be dated, and forwarded to "The Registrar of Friendly Societies, Abingdon Street, Westminster, S.W."

Form B.-Reg. 5.

Trade Union Acts, 1871 and 1876.

Certificate of Registry of Trade Union.

It is hereby certified that the has been registered under the Trade Union Acts, 1871 and 1876, this day of 18 .

[Seal of Central Office, or signature of Assistant Registrar for Scotland or Ireland. ' 
Form C.-Reg. 7.

Trade Union Acts, 1871 and 1876.

Applioation for Registry of partial Alteration of Rules.

Trade Union. Register No.

This application for the registry of a partial alteration of the rules of the trade union, is made by the seven persons whose names are subscribed at the foot hereof.

With this application are sent-

(a.) A printed copy of the registered rules marked to show where and in what way they are altered:

(b.) Two printed [or written] copies of the alteration, each marked O., signed by each of the applicants :

(c.) A statutory declaration of an officer of this trade union, that in making the alteration of rules now submitted for registry the rules of the Trade Union were duly complied with.

2. We have been duly authorised by the Trade Union to make this application on its behalf, such authorisation consisting of a resolution passed at a general meeting on the* day of

$\begin{array}{ll}\text { (Signed) } & 1 . \\ & 2 . \\ & 3 . \\ & 4 . \\ & 5 . \\ & 6 . \\ & 7 .\end{array}$

To the Registrar of Friendly Societies, Abingdon Street, Westminster.

Form D.-Reg. 7, 9.

Trade Union Acts, 1871 and 1876.

Declaration accompanying Alteration of Rules.

Trade Union.

Register No.

I of , an officer of the above-named trade union, do solemnly and sincerely declare that in making the alteration of the rules of the trade union, the application for the registry of which is appended to this declaration, the rules of the said trade union have been duly complied with.

And I make this solemn declaration, conscientiously believing the same to be true, and by virtue of the provisions of the Statutory Declarations Act, 1835.

Taken and received before me, one of

Her Majesty's justices of the peace

for the county of at , at day of, in the said county, this 18 .

* Here insert the date, or if there was no such resolution, state in what other way the authorisation was given.

$\dagger$ Here insert the date. 
Form E.-Reg. 8.

Trade Union Acts, 1871 and 1876.

Certificate of Registry of partial Alteration of Rules.

Trade Union. Register No.

It is hereby certified that the foregoing partial alteration has been registered under the above-mentioned Acts this day of, 18 .

[Seal of Central Office, or signature of Assistant Registrar for Scotland or Ireland.]

Form F.-Reg. 9.

Trade Union Acts, 1871 and 1876.

Form of Application for Registry of complete Alteration of Rules.

\section{Trade Union. Register No.}

1. This application for the registry of a complete alteration of the registered rules of the

Trade Union is made by the seven persons whose names are subscribed at the foot hereof.

2 . The complete alteration submitted for registry is the substitution of the set of rules, two printed copies of which (each copy marked P., and signed by the applicants) accompany this application, for the set of rules already registered.

3. The name under which it is proposed that the trade union on behalf of which this application is made shall be registered is as set forth in Rule No.

To the best of our belief there is no other existing trade union, whether registered or not registered, the name of which is identical with the proposed name, or so nearly resembles the same as to cause confusion.

* Name of Trade Union.

* Name of Trade Union.

* Name of Trade Union.

4. The place of meeting for the business of the * and the office to which all communications and notices may be addressed, is at

, as set forth in Rule No.

5. The * was established on the day of

6 . The whole of the objects for -which the * is established, and the purposes for which the funds thereof are applicable, are set forth in Rule No.

7. The conditions under which members may become entitled to benefits assured are set forth in Rule No.

8. The fines and forfeitures to be imposed on members are set forth in Rule No.

9. The manner of making, altering, amending, and rescinding rules is set forth in Rule No.

10. The provision for the appointment and removal of a general committee of management, of trustee or trustees, treasurer, and other officers, is set forth in Rule No. 
11. The provision for the investment of funds and for the periodical audit of accounts is set forth in Rule No.

12. The provision for the inspection of the books and names of the members by every person having an interest in the funds is set forth in Rule No.

13. The provision for the manner of dissolving the trade union is set forth in Rule No.

14. This application is accompanied by a statutory declaration of , an officer of the said trade union, to the effect that in making the alteration of rules now submitted for registry the rules of the trade union were duly complied with.

15. We have been duly authorised by the Trade Union to make this application on its behalf, such authorisation consisting of a resolution passed at a general meeting held on the * day of

(Signed)

$$
\begin{aligned}
& 1 . \\
& 2 . \\
& 3 . \\
& 4 . \\
& 5 . \\
& 6 . \\
& 7 .
\end{aligned}
$$

day of 18.
The Registrar of Friendly Societies,
28, Abingdon Street,
Westminster, S.W.
* Here

insert the date, or, if there was no such resolution state in what other way authorisation was given.

Form G.-Reg. 10.

Trade Union Acts, 1871 and 1876.

Certificate of Registry of complete Alteration of Rules.

$$
\text { Trade Union. Register No. }
$$

It is hereby certified that the set of rules, copy whereof is appended hereto, has been registered under the above-mentioned Acts in substitution for the set of rules already registered for the

Trade Union this day of 18 . [Seal of Central Office, or signature of Assistant Registrar for Scotland or Ireland.] 
Form H.-Reg. 11.

Trade Union Acts, 1871 and 1876.

Application to record Rules registered in another country.

Trade Union.

Register No. the case may be.]

- [Add England, Scotland, or Ireland, as

To the Registrar of Friendly Societies.

Application to record the rules of the Trade Union is made by the secretary of the same.

1. The trade union carries [or intends to carry] on business in [Scotland, Ireland, or England, as the case may be] as well as in England, Scotland, or Treland where the same is registered.

2. With this application are sent two printed [or written] copies of the rules of the trade union, one of such copies being under the seal of the Central Office [or under the signature of the Assistant Registrar for Scotland or Ireland]. (Signed)

Registered Office Date

Secretary.

Form I.-Reg. 11.

Trade Union Acts, 1871 and 1876.

Application to record Amendments of Rules already recorded. Trade Union.

Register No. the case may be.]

Recorded in may be] No.

. [Add England, Scotland, or Ireland, as [Scotland, Ireland, or England, as the case

To the Registrar of Friendly Societies.

Application to record an amendment of the rules of the trade union is made by the secretary of the same.

1. The trade union carries on business in [Scotland, Ireland, or England, as the case may be] as well as in [England, Scotland, or Ireland] where the same is registered.

2. The rules of the trade union have been already recorded in [Scotland, Ireland, or England, as the case may be].

3. With this application are sent two printed [or written] copies of an amendment of such rules lately registered, one of such copies being under the seal of the central office [or under 
the signature of the Assistant Registrar for Scotland or Ireland].

(Signed)
$\begin{aligned} & \text { Registered Office } \\ & \text { Date day of }\end{aligned}$. $^{\text {Secretary. }}$

ForM J.-Reg. 12.

Trade Union Acts, 1871 and 1876.

Request to withdraw or cancel Certificate of Registry.

Trade Union.

Register No. [If the trade union is registered in Scotland or Ireland, add Seotland or Ireland, as the case may be.]

To the Chief Registrar [or in the case of a trade union registered and doing business in Scotland or Ireland exclusively, to the Assistant Registrar for Scotland or Ireland, as the case may be].

1. The above-mentioned trade union desires that its certificate of registry under the Trade Union Acts may be withdrawn [or cancelled] on the following ground, viz., [state reason for desiring withdrawal or cancelling of certificate of registry] and at a general meeting * duly held on the day of 18 , it was resolved as follows :-

"That the trustees be authorised to request the Chief (or Assistant) Registrar to withdraw [or cancel] the certificate of registry of this trade union."

2 . This request is made by the trustees accordingly.

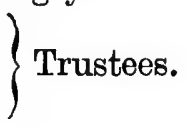

Registered Office

Date 18 .

* If not at a general meeting state in what manner the request has been determined upon.

ForM K.-Reg. 13.

Trade Union Acts, 1871 and 1876.

Notice before withdrawal or cancelling of Certificate of Registry.

Trade Union.

Register No. [If the trade union is registered in Scotland or Ireland, add Scotland or Ireland, as the case may be.]

Notice is hereby given to the above-mentioned trade union that it is the intention of the Chief Registrar [or Assistant Registrar for Scotland or Ireland, as the case may be] to pro- 
* This ceed on the * day of 18 , to cancel [or to withdraw] will be not the registry of the trade union, unless cause be shown to the less than contrary in the meantime.

two

months

after the

date of the notice.

The ground of such proposed cancelling [or withdrawal] is that the certificate of registry has been obtained by fraud [or mistake], or that the registry of the trade union has become void under s. 6 of the Trade Union Act, 1871, or that the trade union has wilfully and after notice from me violated the provisions of the above-mentioned Acts or has ceased to exist. [The facts should be briefly specified where practicable.]

(Signature)

Chief Registrar [or Assistant Registrar

Date for. Scotland or Ireland].

Form L.-Reg. 14.

Trade Union Acts, 1871 and 1876.

Withdrawal or cancelling of Certificate of Registry. Trade Union.

Register No. [If the trade union is registered in Scotland or Ireland, add Scotland or Ireland, as the case may be.]

The certificate of registry of the above-mentioned trade union is hereby withdrawn or cancelled at its request [or as the case may 'be. The Registrar may, if he thinks fit, add a statement, as in Form $K$., of the ground of the cancelling.

(Signed)

Chief Registrar [or Assistant Registrar

Date for Scotland or Ireland].

Form M.-Reg. 15.

Trade Union Acts, 1871 and 1876.

Notice of Change of Registered Office.

Trade Union. Register No. [If the trade union is registered in Scotland or Ireland add Scotland or Ireland, as

To the Registrar of the case may be.]

Friendly Societies.

Notice is hereby given that the registered gffice of the abovementioned trade union is removed from in the parish of 


\section{FORMS.}

, and is now situate at county of

Dated this in the parish of

in the

18

This

part to be detached by the Registrar when the not have complied with the provisions of the Act.

Received this tered office of the county of day of notice , Register No. , to in the [Seal of Central Office, or signature of a Registrar.]

\section{notice is}

registered and returned to the trade union.

ForM N.-Reg. 16.

Trade Union Acts, 1871 and 1876.

Application for Approval, and Notice of Change of Name.

Name already registered

Register No. [If the trade union is registered in Scotland or Ireland, add Scotland or Ireland, as the case may be.]

To the Chief Registrar [or Assistant Registrar for Ireland or Scotland, as the case may be] and Central Office.

Application for approval of a change of name of the abovementioned trade union is made by the three persons whose names are subscribed at the foot hereof.

The following is a copy of a resolution passed by the consent of two-thirds of the total number of members of the trade union :-

[The resolution to be copied at length.]

And notice of the said change is hereby given to the central office for registry thereby.

Registered Office Date
1.

2.

Secretary. 3.

4.

$18 \cdot 5$

6.

7.
Members. 
Form O.-Reg. 16.

Trade Union Acts, 1871 and 1876.

Declaration to accompany Application for Approval of Change of Name.

County of to wit.

Name of trade union

Register No.

[If the trade union is registered in Scotland or Ireland, add Scotland or Ireland, as the case may be.]

I, of , the secretary of the above named trade union, do solemnly and sincerely declare that in making the change of name, notice of which is appended to this declaration, the provisions of the $39 \& 40$ Vict. c. 22 , in respect of change of name, having been complied with.

And I make this solemn declaration, conscientiously believing the same to be true, and by virtue of the provisions of the Statutory Declarations Act, 1835.

Taken and received before me, one of His Majesty's justices of the peace for the said county of , at in the said county, this day of

This

form applies (with the necessary modifications) to a branch of a trade union.

['This clause will not be necessary where the application is in conse-
Form P.-Reg. 17.

Trade Union Acts, 1871 and 1876. Application for Direction to transfer Stock.

Trade Union. Register No.

Application for a direction to transfer stock is made by the four persons whose names are subscribed at the foot hereof, being the Secretary and three members of the above-mentioned trade union.

1. The trade union on the day of , duly appointed , of in the county of [here name and describe all the trustees then appointed $]$ to be trustees.

2. On the day of the sum was invested in the purchase of stock transferable at the Bank of England [or Ireland] in the names of the said trustees, and the same is still standing in their names, as follows [state exactly in what names the stock stands] :-

3. The said is absent from Great Britain [or Ireland] [or became bankrupt on the day , or filed a petition (or executed a deed) for liquidation of his affairs by assignment or arrangement or for composition with his creditors, on the day of , or has become a lunatic, or died on the day of or has not been heard of for years, and it is not known whether he is living or dead.] 
4. On the day of the trade union duly removed the said from his office of trustee, and appointed [give full name and description] in his place.

5. Since such removal application has been made in writing to the said [removed trustee] to join in the transfer of the said stock into the names of the said [here give the names of the other trustees, and of the new trustees appointed in the place of the one removed] as trustees for the said trade union, but he has refused to comply [or has not complied] with such application. [This paragraph may be omitted, or varied, as the facts require.]

6. This application to the Registrar is made pursuant to $39 \& 40$ Vict. c. 22 , s. 4 , that he may direet the said stock to be transferred into the names of the said as trustees for the trade union by

[This blank should be filled by the names of the surviving or continuing trustees (if any), and if they be willing and able to make the transfer; or if there be no such trustee, or if any such trustee refuse or ba unable to make the transfer, then by the words the Accountant General, or Deputy, or Assistant Accountant General of the said Bank; and a full statement of the facts and of the grounds of suich refusal or inability should be made.]

Registered Office Date day of 18 .

To the Registrar.

Secretary.

Member.

Member.

Member.

quence of the mere removal of a trustee.] 
Bank of England [or Ireland] in the names of the said trustees, and the declarant believes that it is still standing in their names, as follows [state as in Form $P$.] :-

That the said is absent from Great Britain [or Ireland] [or, became bankrupt, \&c., as in Form P.]

That on the day of 18 , the said was removed from his office of trustee, and was appointed in his place.

That since such removal application has been made in writing to the said to join in the transfer of the said stock into the names of the said as trustees for the said trade union, but he has refused to comply [or has not complied] with such application. [This paragraph may be omitted or varied as the facts require.]

And I make this solemn declaration, conscientiously believing the same to be true, and by virtue of the provisions of the Statutory Declaration Act, 1835.

Taken and received before me, one of

His Majesty's justices of the peace

for the said county of , at in the said county, this day of

Form R.-Reg. 20.

This

form

applies,

with the

necessary modifica-

tions, to a branch of a trade union.

\section{* The}

para-

graphs marked (a) or $(b)$ will be used as the case requires.

\section{Trade Union Acts, 1871 and 1876.}

\section{Direction by the Registrar to transfer Stock.}

Whereas it has been made to appear to the Registrar that stock, transferable at the Bank of England [or Ireland] is now standing in the names of and as trustees of Trade Union registered under the above-mentioned Acts. And that the said is absent from Great Britain [or Ireland, or became bankrupt, \&c., as in F'orm P.]

And that has been appointed trustee of the said trade union in place of the said

*(a.) The Registrar under the said Acts hereby directs pursuant to section 4 of the $39 \& 40$ Vict. c. 22 , that the said sum of so standing in the books of the Governor and Company of the Bank of England [or Ireland] in the names of the said the names of the said

(b.) And that there is no surviving or continuing trustee of the said trade union, or that the surviving or continuing trustee or trustees refuse or are unable to transfer the said stock.

The Registrar under the said Acts hereby directs, pursuant to section 4 of the $39 \& 40$ Vict. c. 22 , that the said sum of , so standing in the books of the Governor and Company of the Bank of England [or Ireland] be transferred in the said books by the Accountant-General, or Deputy or Assistant 


\section{FORMS.}

Accountant-General, of the said Bank into the names of the said

\section{Address}

Date $18^{\circ}$

[Seal of Central Office, and signature of Chief Registrar or Assistant Registrar for England, or signature of Assistant Registrar for Scotland or Ireland.]

Form S.-Reg. 21.

Trade Union Acts, 1871 and 1876.

Notice of Dissolution.

Trade Union. Register No.

To the Central Office, 28, Abingdon Street, Westminster [or

To the Assistant Registrar for Scotland or for Ireland, as the case may require].

Notice is hereby given that the above-mentioned trade union was dissolved in pursuance of the rules thereof on the day of

Name and address to which registered copy is to be
returned.
Date
18 .

$\begin{array}{ll}\text { 1. } & \text { Secretary. } \\ \text { 2. } & \text { Member. } \\ \text { 3. } & \text { Member. } \\ \text { 4. } & \text { Member. } \\ \text { 5. } & \text { Member. } \\ \text { 6. } & \text { Member. } \\ \text { 7. } & \text { Member. } \\ \text { 8. } & \text { Member. }\end{array}$

Form T.-Reg. 22.

Trade Union Acts, 1871 and 1876.

Notice of Amalgamation of Trade Unions.
(A) Trade Union.
Register No.
(B) Trade Union.
Register No.
[alnd so on if more than two].

To the Central Office, 28, Abingdon Street,

Westminster.

Notice is hereby given, that by the consent of two-thirds of the whole number of members of each or every of the above-

$$
\mathrm{R} 2
$$


mentioned trade unions they. have resolved to become amalgamated together as one trade union.

And that the following are the terms of the said amalgamation [state the terms] :-

And that it is intended that the trade union shall henceforth be called the

Acoompanying this notice is a copy of the rules intended to be henceforth adopted by the amalgamated trade union [which are the rules of the Trade Union].

[To be signed by seven members and the secretary of each trade union.]

Name and address to which

registered copy is to be

sent.

Dato

18

Form U.-Reg. 22.

Trade Union Acts, 1871 and 1876.

Trade Union. Register No.

I, of , the secretary of the above-mentioned trade union, do solemnly and sincerely declare that in the amalgamation of the said trade union with the, notice of which is appended to this declaration, the provisions of the Trade Union Act Amendment Act, 1876, in respect of amalgamations, have been duly complied with.

And I make this solemn declaration, conscientiously believing the same to be true, and by virtue of the provisions of the Statutory Declarations Act, 1835.

Taken and received before me, one of

His Majesty's justices of the peace

for the said county of

in the said county, this

18 .

day of 


\section{APPENDIX IV.}

\section{SPECIMEN RULES OF A REGISTERED 'TRADE UNION.}

\section{RULE I.}

Name, Objects, and Constitution.

1. The Society formed under these rules, hereafter called "The Name. Society," shall be known by the title of

2. The Society shall consist of [members, branches, \&c.].

3. The objects for which the Society is established are:

Trade to

4. The Society shall be divided into branches, to one of which every member shall belong. No branch shall consist of more than

members, unless by consent of the District Committee. 'The local limits of each branch, the formation of new branches, and the number of members in each, shall be determined as hereafter mentioned. Every branch shall have powers as provided by these rules, and shall be subject in accordance with them to the control and direction of the general governing bodies of the Society and their officers; but every branch shall appoint its own officers and conduct its own business in the manner set forth in the following rules.

5. There shall be a General Office, which shall be the registered office of the Society, and which shall be the place of meeting for its business, at , in the county of or Ireland, (as the case may be).

which

members may

belong.

Objects.

Division into branches.

\section{RULE II.}

\section{Elections and Voting.}

1. All elections and voting shall be conducted in the following manner :-

Any member may nominate any branch or general officer without a seconder All nominations must be made days previous to their election. Should only one member accept nomination for any office, he shall be declared duly elected. If two or moro persons accept nomination for any office, the votes shall be taken separately.

All elections for branch officers (with the exception of secretary) shall be by show of hands. The votes shall be taken by ballot for the following: General Secretary and all general officers, delegates to delegate meetings, etc.

Branches shall have power to provide the means of voting by ballot, and in such cases as are so decided the ballot boxes shall remain open for voting as follows:

2. In all elections under the direction of the Executive Council, nomination and election schedules shall be posted from the offices. A date shall be specified on which all voting shall cease, and all votes taken on or before the specified date, providing that they

Nomination of officers and delegates.

Election of officers and delegates.

Regulations for voting. 
have been taken in accordance with this rule, shall be valid notwithstanding any neglect on the part of any officers, or from any Pro tem- other causes whatever. In the event of any general officer pore occu- resigning or being removed by death or otherwise, another pation of election shall take place, and the appointment then made shall be office. for the remainder of the unexpired term. But if it be necessary to fill the office temporarily, such office shall be filled by Council.

Intimida- 3. Any member intimidating members voting shall be fined tion.

Disqualification. [specify amounts].

4. No member shall be nominated, elected to, or continue in, any office if $s$. in arrears.

\section{RULE III.}

\section{Branch and Other Meetings.}

Branch meetings.

\section{Branch} powers.

Quarterly meetings.

Branch books.

Branch powers re niembers of other branches.

Special meetings.

Constitution of Committee.
1. A meeting of the members of each branch shall be held every for the transaction of its business. All members' contributions and other payments, unless otherwise provided for by rule No. 11, must be paid at this meeting.

2. Branches shall have power to submit to the votes of their members the question of levying the members of such branches for affiliation. Branches shall have power to raise funds by levy on their members for the purpose of :

3. The quarterly meeting shall be held on

when the report of the income and expenditure of the last quarter shall be read over by the auditors to the meeting. All officers shall be in attendance. The retiring president shall preside until the quarterly report be received by the branch, and the new president shall then take his place.

4. The branch books shall be open at all reasonable times to inspection by any member or person having an interest in the funds.

5. Any member desirous of visiting a branch other than that of which he is a member, shall be admitted on producing such evidence as may be deemed satisfactory by the president. He shall not be allowed to take part in the proceedings unless with the consent of the meeting.

6. In cases of emergency the president, secretary, and committee of a branch, shall have the power of summoning a general meeting; the business shall be stated and the hour of meeting shall be intimated to the members.

\section{RuLE IV.}

\section{Branch Committee.}

1. There shall be a branch committee (which shall be, in the case of single branches, the District Committee), composed of members who have been in the Society years (except in new branches), who shall be elected at the general summoned meeting for the election of officer's every consist of not less than nor more than , exclusive of 
president and secretary; each member being elected for months, the majority and the minority retiring alternately. Branches having members or under, shall have, and those above shall have members of committee. A majority of the committee shall form a quorum.

2. Members of the branch committee shall attend at such time and place as may be specified by the president, secretary, or a majority of the committee who shall order the secretary to issue surnmonses for that purpose. All decisions arrived at by the committee shall be fiual, subject to the right of appeal, within to a summoned meeting of the branch.

3. The committee shall have power to summon any officer or Commember to attend their meetings, and to call a special summoned mittee's neeting of the branch when they deem it necessary. It shall also powers. have access to all books and accounts of the branch bearing upon the matter to be decided.

4. Branch committees shall, every months, examine into cases of long-continued receipt of benefit, and shall have power to bring cases of suspicious conduct or incompetency before the branch or the Executive Council, with a view to the member being dealt with.

5. The branch president and secretary shall attend, and may express their opinions at all meetings, but shall not vote, nor be for any other purpose members of the committee, except in the event of the votes being equal, when the president shall give a casting vote. The minutes of the committee's proceedings shall be signed by the president at the close of the meeting, and shall be read at the following branch meeting.

\section{Rule V.}

\section{Branch Officers.}

Con-

vening of meetings.
Investiga-

tion of conduct.
Status of president and secretary.
1. Each branch of the Society shall be under tho government of a president, and such other officers as the rules direct.

2. All officers before going out of office shall deliver up to the new officers all books, moneys, papers, receipts, letters, or any other property that may be in their possession belonging to the Society.

Government.

Giving up possession on leaving office.

\section{Rule VI. \\ President.}

1. The president of each branch shall be elected by a majority of the members present at the general summoned meetings in

2. The president shall preside over all meetings connected with the branch. He shall, when the auditors deliver their report, supervise the accounts of the branch. If the report receive the approval of the branch, the president shall affix his signature thereto. He shall read, or appoint a member to read, the correspondence as supplied by secretary. In the absence of the president his office shall be filled by election from the members present.
Election of.

Duties of. 


\section{RULe VII.}

\section{Branch Secretary.}

Nomina-

tion.

Duties.

Entry of members.

Quarterly report.

Yearly report.

\section{Date of} quarterly and yearly reports.

Unemployed.

Alteration of rules.

Record of beneroJent grants.

Record of accidents.

Resignation or removal.
1. The secretary of each branch shall be nominated on

2 . The secretary shall attend the meetings of his branch, and shall enter all levies, contributions, and arrears deducted from benefits in the book provided for that purpose, and in the members'. contribution cards, and sign the same. He shall also post the dates, amounts, and names of each levy. He shall keep the accounts of his branch and all documents, accounts, books and papers belonging to his branch in such form, manner, and place as the branch may appoint, and shall conduct such correspondence as belongs to his office. He shall send notice to all members who are in arrears, and $a$ further notice when in arrears, and in addition shall post their names in the meeting-room.

3. The branch secretary, on the admission of any candidate, shall issure for him an entrance card, and shall enter in the entrance book and card the amounts paid by or on account of such candidate, before and after his admission, until the whole entrance fee has been paid. He shall send all forms in connection therewith to the General Office within one month after admission or rejection.

4. The secretary shall prepare a report at the end of each quarter, containing a detailed account of the income and expenditure as set forth in the forms provided for the purpose, the total amount of arrears, with the average per member on the last meeting night of the quarter, the number of members in the branch, and the number and names of those who have been admitted or excluded during the quarter, together with such other information as to age, trade, etc., as may be required by the General Office for the purpose of reference.

5. He shall prepare a yearly report. He shall send with the yearly report to the General Office the auditors' names for the year, so that they may be published with the branch accounts, and also a duplicate of the financial statement contained in the yearly report, the names and addresses of the secretary, treasurer, and trustees.

6. The secretary shall send in the quarterly and yearly accounts, duly signed by the auditors and branch president, to the General Secretary within days of the close of each quarter and year, but in no case shall he forward the same without first submitting them to the branch meeting for approval.

He shall from time to time furnish to the registrars a list of the unemployed members in the branch.

He shall forward to the General Offices all suggestions which have been adopted by the branch for alteration of rules.

He shall enter a record of all benevolent grants as they are paid to members of his branch.

He shall enter notification of accidents in the branch minute book, order the payment of funeral benefit, and notify the General Office of the death of a member of his branch.

7. Any secretary resigning office shall give to his branch one month's notice. Any secretary's conduct being found unsatisfactory by a branch, he shall be liable to be removed from office, and on removal shall deliver up all books, papers, and other property 
of the Society to the trustees of the branch. No secretary shall be allowed to act either as treasurer or trustee of his branch. The branch secretary's salary shall be paid quarterly by the branch treasurer, on receipt by him of an order, countersigned by the branch auditors, for the number of members belonging to his branch on the last meeting night in each quarter.

'The scale of secretaries' salaries shall be as follows:-

\section{RULE VIII.}

\section{Auditors.}

1. Every branch shall elect auditors, (and a provisional auditor), each of whom shall serve for

auditors, (and a provisional

No president, secretary, trustee, or treasurer shall be eligible to audit the accounts of their own branches.

2. The duties of auditors shall be to audit the income and expenditure of a branch. They shall, in the course of the audit, examine all the books kept by the branch or its officers. They shall report whether such books have or have not been correctly aud properly kept. They shall examine the expenditure of the branch, whether relating to benefits, payments to other branches, the General Office, the District Committee, or other incidental expenses. They shall demand receipts for every item of expenditure and money deposited. They shall examine the accounts of every member who has been on benefit.

3. They shall examine the quarterly and, during the audit for the last quarter of the year, the yearly report of the branch secretary, and, on being satisfied of its correctness by examination of all necessary documents, shall sign the same. Such reports shall contain a statement of the receipts and expenditure during the last quarter, of the money in the hands of the branch at the commencement and conclusion of the quarter or year, and any other necessary information relative to the accounts, or the way in which the same are kept.

4. All audits must commence within of the quarter.

days after the close Time of audit.

\section{RULE IX.}

\section{Branch Treasurers and Trustees.}

1. The treasurer of each branch shall be elected annually, on , and shall be subject to dismissal. He shall pay all cheques signed by the secretary; but in no case shall he advance money to the secretary on any cheque presented by him unless such cheque be signed by one of the auditors.

Election of.

Qualitica-

tion and

disqualification.

Audit.

Expendi-

ture of

branch.

Receipts.

Benefits.

Quarterly and yearly report.

Qualification, election and removal. Duties.

Rule X.

Vacant Books.

1. Every branch shall be provided with a vacant book, which How kept. shall be kept as the branch may direct. 
Signature of mem-

ber

receiving

relicf.

Penalties

for non-

observ-

ance.

Notifica-

tion of

vacalley or of starting work.
2. Every member out of employment who is in receipt of donation shall sign his name and place the number of his contribution card in the vacant book. Any member neglecting to sign as specified shall for each neglect forfeit his day's allowance.

3. When a member leaves one situation to go to another, or if he give or receive notice to leave his employment, he shall give information, in writing, to the secretary of the branch to which he belongs, and to the nearest branch secretary or vacantbook keeper, within hours, or be fined for each neglect, unless a satisfactory reason be given to the branch. Any member commencing work must inform his branch secretary where he is at work, in writing, within hours, and also give his rate of pay within days after receiving the same.

\section{RuLE XI.}

\section{District Committee.}

Constitu-

tion of

com-

mittee.

Majority

to form

quorum.

Powers of.

Wages,

hours, and

con-

ditions.

Sub-com-

mittees

and depu-

tations.

Election

of officers.

Powers of

com-

mittecs in

regard to

disputes.

Voting on

general

district

disputes.

Secre-

tary's

duties.

Com-

mittee

investiga-

tion.
1. In districts having more than one branch, members shall form a District Committee, and each branch shall be represented according to their numbers. A majority of the members of any District Committee shall form a quorum.

2. District Committees shall control vacant-book offices, district registrars, and vacant-book keepers in their districts, but no member of a District Committee may act as a vacant office auditor.

They shall have no jurisdiction in matters of branch business, but shall have power (subject to the approval of the Executive Council) to deal with and regulate the rates of wages, hours of labour, terms of overtime, piece-work, and general conditions affecting the interests of the trade in their respective districts. They shall be allowed to send deputations to employers in their districts with a view to amicable settlement of districts.

3. The election of the President and Secretary of District Committee shall be conducted in like manner as that of Branch Committees.

4. In the case of a dispute the members shall not leave their employment without the approval of the District Committee. No general strike shall be entered upon in any district affecting the whole of the members unless carried by a majority of votes, and no settlement shall be decided upon unless accepted by a majority. The vote shall be taken by ballot.

5. These cretary of each District Committee shall send in a report to every branch in his district on or before the election of officers. He shall submit his accounts for audit to the branch. He shall also inform each branch in the district within three days, of the approval of the Executive Council of any resolution of the committee affecting any trade in the district, and shall report to the Executive Council from time to time as may be found necessary.

6. If a member is charged with any offence an investigation shall be made by the District Committee, and he shall have the right to summon witnesses for his defence, 
RULE XII.

\section{Executive Council.}

1. There shall be an Executive Council, which shall consist of members, including the chairman. They shall be nominated by and from the district committee areas. They shall be elected by the vote of the whole Society, for periods of years, and shall be eligible for re-election. The chairman shall be nominated by the members from the Council, and shall be elected by the vote of the whole Society. The chairman shall preside over all Council meetings, read all letters which require to be submitted to the Council, see that the business is properly conducted according to the rules. He shall also attend all conferences with employers, and shall prepare.and present the case for the Society at such conferences. He shall prepare and issue to each branch secretary once a month a report of the Council's proceedings.

2. The Executive Council shall have the following powers:

3. The Executive Council shall have power, to direct that special audits or examination of branch books be made. They may institute legal proceedings against all officers or members who have in any way defrauded the Society, and against all trustees who may refuse to sign or deliver up to any person appointed by the branch or the Executive Council to receive the same, all bonds, cheques, or other documents which may have been entrusted to their care, or which require their signature.

4. There shall be General Trustees, who shall be elected by

Council's powers. Special audits.

1he legal procecdings.

Election of general trustees.

\section{RuLE XIII.}

\section{General and Assistant Secretaries.}

1. There shall be a General Secretary and

assistants, who Election shall be elected by the members. These officers shall be elected of. for years, and shall be eligible for re-election.

2. Any member who has been in the Society for shall be eligible for nomination as General Secretary or assistant.

3. The General Secretary and assistants shall be under the control of the Council.

4. The General Secretary shall devote the whole of his time to the business of the Society, and shall attend the meetings of the Council. He shall produce all books and papers belonging to his office to the auditors appointed for that purpose every months.

5. The General Secretary shall issue a Monthly Report, statiug the condition of trade in each town, as received from the branch secretaries; he shall, in conjunction with the Council, cause to be printed with such report the decision of any branch upon any case wherein the Society's rules are silent, if such decision be approved of by the Council. Such report shall contain a report of the proceedings of the Council as prepared by the Chairman.

6. The General Secretary shall compile Quarterly and Yearly Reports from the returns received from the various branches, and shall send a copy of the same to every branch of the Society. He

Qualifications.

Control of council.

Duties of gencral secretary.

\section{$R e$}

Monthly

Report.

Quarterly

and

ycarly reports. 
shall send a detailed quarterly account of the expenses, and, in the Re pro- Yearly Report, an abstract of the proceedings of the Council. He ccedings of shall issue a full report of the income and expenditure of the Society council.

Re returus re working every year. He shall also issue yearly, to all district secretaries, a return showing the rates of wages, hours worked, and genoral conconditions obtaining in the various districts of the Society.

ditions.

Audit of general secretary's accounts.

7. The General Secretary's books, receipts, and other necessary documents, shall be audited every half-year by a firm of chartered accountants, whose report shall be issued with the Monthly, Quarterly, and Yearly Reports. The books concerning the Society as a whole shall be kept by the General Secretary at the General Office, and there shall be a registration book kept by the General Secretary, in which the name of each member of the Society shall be entered, stating when and where admitted.

Office 8. The General Office shall be open from:

hours.

\section{RULE XIV.}

\section{Admission of Members.}

Scale for inem-

bership.

Proposal.

Concur-

rence of

candidate.

Qualifica-

tions.

1. The scale of entrances for membership shall be :

2. Candidates for admission shall be proposed and seconded by two members at a branch meeting, and may be admitted at the next branch meeting.

3. Every person, before being admitted, shall as a condition of membership be bound by the rules. He shall sign a form containing all necessary particulars bearing upon bis fitness to become a member. These forms, and all other documents relating to admission, shall be sent to the General Office.

4. Every candidate for admission must be qualified for membership under the following conditions:

Method of proposal.

Majority decide

admission.

Rate of contributions.

Arrears

dis-

entitling

to benefit.

Levies,

when

charged.

Contribu-

tion card.

5. Members proposing and seconding any person shall give all necessary information regarding him.

6. Every admission shall be by a majority of the members present.

\section{Rule XV.}

\section{Contributions and Arrears.}

1. Every member shall pay at the rate of unless otherwise provided for.

2. Any member in arrears over shall forfeit all claim to benefits, until he reduces his arrears below that amount.

3. All levies shall be entered in the contribution cards.

4. Every member shall be supplied annually with a card on which shall be entered his contributions and arrears; any member losing or defacing his card shall be supplied with another. 


\section{RULE XVI.}

\section{Unemployed Benefit.}

1. The amount of benefit to which a member is entitled shall be determined as follows :

2. Should any member of years' standing be discharged or leave his employment under circumstances satisfactory to the branch to which he belongs he shall be entitled to benefit at the rate of :

\section{RULe XVII.}

\section{Sick Benefit.}

1. Any member suffering from sickness shall within days When give notice to the secretary, in writing, and shall be entitled to entitlecl. benefit.

2. A branch may appoint a physician or surgeon who shall investigate and give a certificate as to a member's state of health.

3. The amount of benefit to which a member is entitled on making and sustaining his claim shall be determined as follows:

Amount entitled to.

When entitled.

\section{Rule XVIII.}

\section{Accident Benefit.}

1. Any member not in arrears more than accident or otherwise, shall receive the sum of $\mathscr{L}$ on the produc- tion. tion of medical testimony.

2. Any member meeting with an accident, as would entitle him to benefit, shall give notice of the accident to the secretary.

Giving notice.

Doubts arising of sickness.

Amount entitled to.

3. Any member claiming accident benefit shall send to his branch such medical certificates and other evidence relating to his case as he is possessed of.

\section{Rule XIX.}

\section{Superannuation.}

1. Any member years of age who has been years successively in the Society, who is not out of benefit through arrears, and
who through old age or infirmity is unable to obtain the ordinary rate of wages, or (in the case of members who have left the trade) who is unable to follow his usual occupation and applies for superannuation benefit, shall state his case to a meeting of his branch. Should the meeting be satisfied with the validity of his claim, the branch secretary shall furnish all evidence to the Executive Council, who shall have power to grant the sum of $s$.

2. Superannuation benefits shall be payable from the time when When a member has established his claim thereto to the satisfaction of entitled. the Executive Council. He shall be entitled to superannuation benefit irrespective of any income he may derive from other means. 


\section{Rule XX.}

\section{Funeral Benefit.}

To how much cntitled.

Who entitled.

Declaration.

General directions.

Council's powers re investment.

Enumeration of offences.

Convic-

tion in court of justice. Penalties -by whom imposed.

When fines paid.
1. On the death of any member whose arrears at the time of death do not exceed , notice shall be sent to the secretary, who, on the production of the certificate of death, shall pay or cause to be paid to the widow, nominee, or nearest of kin lawfully appointed to receive the same, the sum of (less any arrears or other money owing). The widow or nominee of any other member shall, on death of such member, be entitled in like manner to the said sum.

2. Every branch shall be provided with a declaration book, in which any member can enter as his nominee (such nominee not being an officer of the Society), the name of the person to whom, at his death, the funeral benefit shall be paid.

\section{RULE XXI.}

\section{Investment of Funds and Trustees Duties.}

1. All money subscribed or paid and all property acquired or owned for the objects mentioned in these rules belonging to the Society, or any part thereof, shall be vested as follows:

2. The Council shall invest the funds of the society in the investments being be made in the names of and carried out by the general trustees.

\section{RULE XXII.}

\section{Conduct, Offences, Penalties.}

1. If any member be satisfactorily proved to have stolen the funds or property of the Society; to have been convicted by a Court of Justice; to have, with intent to deceive, tampered with, falsified, or otherwise wilfully misused any books or other documents belonging to the Society; to have, contrary to these rules, obtained possession of, or refused to give up when in his possession, any books, keys, papers, or other documents or effects belonging to the Society or any part thereof, to have refused to sign or execute any cheque, transfer, deed, or other document to which his signature or execution was required by these rules; to have refused to obey these rules, or to comply with any order by them authorised, he shall be fined such sum (not exceeding $£$ ) or suspended from benefit for so long as the committee or branch meeting who have tried him shall think proper, or shall bo excluded from the Society, and forfeit all money paid by him thereto.

2. Any member being convicted by a Court of Justice shall be liable to exclusion or such suspension as the branch to which he belongs may deem fit.

3. All fines imposed shall be inflicted, if relating to branch matters, by the branch secretary, and failing him by the branch president.

4. All fines shall be paid within

weeks from the imposition of such fines. 


\section{RULES.}

5. Members feloniously taking the funds shall be expelled from Comthe Society and prosecuted according to law.

mitting

felony.

\section{RULE XXIII.}

\section{Dissolution.}

The Society may be dissolved by consent of nine-tenths of its How members voting in meeting duly summoned for the purpose; or society whenever the number of members is reduced to a majority may be of the remaining members may, in meeting assembled at the dissolved. registered office of the Society, dissolve the Society; and after Division discharging all debts and liabilities legally incurred in the Society's of moneys. name they may divide the funds among the members in equal portions. 


\section{APPENDIX $\mathrm{V}$.}

\section{POWERS OF TRADE UNIONS UNDER THE NATIONAL INSURANCE ACT, 1911 (1 \& 2 GEo. 5, c. 55).}

UNDER the Insurance Act, 1911, a trade union may become an approved society if formally approved by the Insurance Commissioners; or a trade union may establish a separate section for persons insured under the Insurance Act, in which case, if such separate section be formally approved, it may become an approved society $(a)$. Such security as the Commissioners consider sufficient must be given by the trade union or special section to provide against misappropriation of the goods, $(b)$ and, if the trades union have branches, the security must be given for each branch $(c)$.

Trade unions which are approved societies must have the rules dealing with national insurance approved by the Commissioners $(d)$. Branches of approved societies must obtain permission from the Commissioners to secede: (e). Members leaving a trade union for another approved society have their rights under the insurance scheme transferred with them $(f)$. The accounts of the trade union, so far as concerned with the insurance scheme, must be kept and audited as the Commissioners prescribe $(g)$, and their assets and liabilities must be valued every three years by a Treasury valuer $(h)$. If a surplus be paid, it may be distributed according to a scheme sanctioned by the Commissioners; if a deficit, the deficit must be made good in accordance with a scheme, to be approved of by the Commissioners $(i)$.

Special provisions both as to surplus and deficit are applied to branches of an approved society (k).

A trade union which is an approved society must invest any sums paid to it for investment in trustee stock or in securities under the Local Loans Act, $1875(l)$. Deposits between a trade union which is an approved society and insured members, or between various branches must be settled according to the rules of the trade union, but an appeal lies to the Insurance Commissioners $(m)$.

The business of a trade union under the National Insurance Act, so far as it is not expressly provided for by that Act, is deemed to be conducted under the Trade Union Acts $(n)$.

With regard to qualification for health insurance, any person of 16 years of age and upwards, if engaged in regular occupation and

(a) Sect. 22.

(b) Sect. $25(1)$.

(c) Sect. 25 (2).

(d) Sect. 26.

(e) Sect. 27 (1).

$(f)$ Sect. 30. (g) Sect. 34.

(h) Sect. 35 .

(i) Sect. 37.

(k) Sects. 36, 37.

(l) Sect. 55.

$(m)$ Sect. 66.

(n) Sect. 75. 
at least partially dependent for their livelihood on their earnings from that occupation, may be insured through a trade union (o).

The contributions and benefits are as laid down in sections 3 to 13 and Schedules 1 to 4 of the Act.

Sickness, disablement and maternity benefit may be administered to members of the trade union through the trade union $(p)$. Subject to the Commissioners' approval and certain statutory requirements, the existing rules of the union or new rules may provide the method of distribution of such benefit $(q)$.

With regard to Unemployment Insurance, the Board of Trade may, on the application of a trade union whose rules provide for unemployment benefit, pay to the trade union a sum equivalent to the sum the members would have received under the Act if not insured through the trade union $(r)$. The trade union may treat the unemployment contributions as subscriptions for unemployed benefit to the trade union, regardless of what the rules provide, and may reduce the rates of subscription of the members for unemployed benefit accordingly $(s)$. The Board of Trade may also pay to trade unions insuring their members against unemployment, not more than one-sixth of the total annual amount spent during the preceding year by the trade union on unemployment benefit, whether such of the members of such trade union were entitled to insure under the National Insurance Act against unemployment or not $(t)$.

The persons who are insurable under the Act against unemployment are persons engaged in building, construction of works, shipbuilding, mechanical engineering, ironfounding, construction of vehicles and saw milling, and such other trades as may be added, subject to statutory requirements by the Board of Trade $(u)$. The contributions are laid down in section 80 and Schedule 8 of the Act.

To obtain national unemployment benefit through his union in the manner above described, the workman must have been employed for at least half a year for five years and must be capable of being able to find work. Refusal to take work at a rate lower than the standard will not disqualify him $(x)$, but refusal through a trade dispute will $(y)$; loss of employment through misconduct will disqualify for six weeks $(z)$.

The determination of claims is effected by a Court of Referees, consisting of employers, workmen and a chairman appointed by the Board of Trade $(a)$. An umpire appointed by His Majesty has power to decide matters of disagreement between insurance officers and the Court of Referees.

Regulations, generally, as to unemployment insurance may be made by the Board of Trade $(b)$. The unemployment fund to which reference has been made is also controlled by the Board of Trade $(c)$.

(o) Sect. 1.

(p) Sect. 14.

103.

(q) Sect. 26.

(x) Sect. 86.

(r) Sect. $106(1)$

(y) Sect. 87 (1).

(s) Sect. 106 (2).

(z) Sect. 87 (2).

(t) Sect. 107.

(a) Sect. 90.

(u) Sect. 84, Schedule 6 ; sect.

(b) Sect. 91.

T.U.

(c) Sect. 92.

Unemployment Insurance 


\section{APPENDIX VI.}

Injunctions granted by the Chancery Division of the Supreme Court of Judicature restricting levies for Parliamentary or municipal representation by trade unions, since the case of The Amalgamated Society of Railway Servants v. Osborne (No. 1), [1909] 1 Ch. 163.

\begin{tabular}{|c|c|c|}
\hline Parties to Action. & Judge. & $\begin{array}{l}\text { Date of Order for } \\
\text { Injunction. }\end{array}$ \\
\hline $\begin{array}{l}\text { Furnie v. Compositors, \&c., } \\
\text { Association. }\end{array}$ & Eve, J. & 20 January, 1910. \\
\hline $\begin{array}{l}\text { Wilson } v \text {. Amalgamated Society } \\
\text { of Engineers. }\end{array}$ & Parker, J. . & 6 May, 1910. \\
\hline $\begin{array}{l}\text { Pearson v. Notts. Miners', \&c., } \\
\text { Association. }\end{array}$ & $\operatorname{Parker,.J.~\cdot ~\cdot ~\cdot ~}$ & 23 June, 1910. \\
\hline $\begin{array}{l}\text { Joyce } v \text {. Society of Operative } \\
\text { Stonemasons and others. }\end{array}$ & Swinfen-Eady, J. & 23 June, 1910. \\
\hline $\begin{array}{l}\text { Worthy } v \text {. United Pattern- } \\
\text { Makers' Association. }\end{array}$ & Parker, J. . & 4 July, 1910. \\
\hline $\begin{array}{l}\text { Browne } v \text {. Devonport Labourers' } \\
\text { Union. }\end{array}$ & Swinfen-Eady, J. & 15 July, 1910. \\
\hline $\begin{array}{l}\text { Fisher } v \text {. Derbyshire Miners' } \\
\text { Association. }\end{array}$ & Joyce, J. . & 15 July, 1910. \\
\hline $\begin{array}{l}\text { Wright } v \text {. North Wales Miners' } \\
\text { Association. }\end{array}$ & Joyce, J. . & 15 July, 1910. \\
\hline $\begin{array}{l}\text { Wight } v \text {. Buckland and others } \\
\text { (Postmen's Federation). }\end{array}$ & Warrington, J. · & 28 October, 1910. \\
\hline $\begin{array}{l}\text { Dyson } v \text {. Durham Colliery } \mathrm{Me}- \\
\text { chanics' Association. }\end{array}$ & Eve, J. & 4 November, 1910. \\
\hline $\begin{array}{l}\text { Cowey } v \text {. Durham Miners' As- } \\
\text { sociation. }\end{array}$ & Neville, J. . & 11 Norember, 1910. \\
\hline $\begin{array}{l}\text { Fisher } v \text {. The Derbyshire Miners' } \\
\text { Association. }\end{array}$ & Eve: J. & 12 December, 1910. \\
\hline $\begin{array}{l}\text { Logan v. Chatham Government } \\
\text { Labourers' Union. }\end{array}$ & Neville, J. . & 21 December, 1910. \\
\hline $\begin{array}{l}\text { Catterall } v \text {. Grime (The Opera- } \\
\text { tive Cotton Spinners and } \\
\text { Turners). }\end{array}$ & Parker, J. . & 27 March, 1911. \\
\hline $\begin{array}{l}\text { Hughes } v \text {. Chadwick (The Bury, } \\
\text { Radcliffe and District Cotton } \\
\text { Operatives and the Amal- } \\
\text { gamated Weavers' Associa- } \\
\text { tion). }\end{array}$ & Parker, J. . & 27 March, 1911. \\
\hline $\begin{array}{l}\text { Colbran v. The Motor Drivers' } \\
\text { Union. }\end{array}$ & Scutton, J. . & 13 April, 1911. \\
\hline $\begin{array}{l}\text { Wilson } v \text {. Amalgamated Society } \\
\text { of Engineers. }\end{array}$ & Parker, J. · · & 27 April, 1911. \\
\hline Wight $\vartheta$. Buckland and others . & Warrington, J. . & 18 October, 1911. \\
\hline
\end{tabular}




\section{INDEX.}

ACtion. (See also "JURIsDicTION," “ PROCED URE.")

by and against trustees, 17 , $19,175-177,179$

by branch, 133, 138, 153$155,178,179$

for damages, see " $\mathrm{DA}_{\mathrm{A}}$ MAGES"

for declaration, see " $\mathrm{DE}$ CLARATION"

for declarator, see " $\mathrm{DE}$ CLARATION"

for injunction, see "INJUNCTION"

for interdict, see "INJUNCTION"

for reinstatement in union, $123,156-158,16 \tilde{0}, 166$

representative, see "REAGENT, PRESENTATIVE ACTION"

action by, for trade union, 17,18

trade union liability for, $72,73,168,169$

Agreements. (See also "ConTRACT.")

based on unenforceable agreements, 125, 126

benefits to members, securing, unenforceable, 132, 134-137, 145, 148-152, see "Benefits"

enforceability of, 82, 123, 127

inter-union, enforcement of, direct, 123-126, 129, $130,142,148,150$, $156,163-165$

direct and indirect contrasted, 134, 135, $139,143-148,150$ $-152, \quad 15 \tilde{5}, \quad 162$,
AGREEMENTs-continued.

inter-union-continued.

indirect, 123, 132-134, 139,151

meaning of, 138-142

unenforceable, 14, 123$127,129,130,132$, $133-137,142,145$, $148-152,156,163-$ 165

by assignee, 150,153 , 160,180

validity of, 10,11

amalgamation of Trade UNIONS,

authority for, by rules, 40 , 41

how effected, 41

registration of, $41,55,142$, App. II. and III.

statutory provision for, 17

annual Statement of Trade UNION,

copy of, right to, 41,42

APPRENTICESHIP, 1

statutory regulation of, 5

Association. (See also "TradIng Assoctation," "ComBINATION.")

trade union, how far an unlawful, 14

voluntary, trade union a, 14 and trade union, distinguished, 23, 168, 169

Assurance Company. (See "INsurance Company.")

Benefits,

definition of, 155

distribution of, on dissolution, 160, 161

forfeiture of, 113

friendly society, 15, 90, 91, $95-97, \quad 99-102, \quad 116$, $120-122$ 
Benfeits - continued.

intra vires, 27,28

maintenance of action for momber, not a, 178

participation in, 163,165

trade, 15

and friendly society, distinguished, $95-103$, $105,116,120-122$

unenforceable, $124(b), 127$

$-131,145,146,148-$

$150,156,164,165$

Branch,

actions by parent union, $133,138,153-$ 155,179

liability of parent union for, 178

land, power to hold, 50 medical society, power to contribute to, 51,52

property of, 44, 179

trustees of, 44,179

Business. (See "Trading Association.")

Central Office. (See"RegisTRAR.")

Certificate of Registration, App. II. and III.

cancellation of, $30,32,33$, 39

evidence, how far of registration, 30, 32

withdrawal of, 33,41

Civil Litability. (See also " Procedure, Civil..")

for direct interference with others,

concerted, $75-80$

unconcerted, $68-74,79$, 80

Civil Procedure. (See" ProCEDURE, Civil.”)

Collective Bargaining, 4, 11, $62(a)$. (See also "ComBINATIONS," “STRIKE.”)

Com B IN A TIONS. (See also "Liability, Civil AND Criminal," \&c.)

concerted and individual interference with others distinguished, 56,57
Combinations-continued.

conspiracy, $7,74,75,79$, 80

employers, 6

and workmen distinguished, 6

in furtherance of trade dispute legalised, 19, $21(a)$, 75

lawful and unlawful, 6

in restraint of trade, 6,8

resulting in injury, 78 , 80

statutory restriction of, 5,6

strikes, law for lawful, 86, 87

trade union a, $21-23$

Communication of INFormaTIoN, 58, 59. (See also "Picketing.")

Company. (See "Trading Association.")

Conspiracy. (See "CombINATION.")

Contract. (See also "AgreEMENT.")

breach of,

prevention of, formation of, $70,71,79$, 80

procurement of, 68,69 , $70,77,79,80$

legality of, 111

of membership, enforcement of, 158

title to sue in representative action, 177

valid but unenforceable, $157,159,160$

Corporation, 26. (See also "INCORPORATION.")

trade union, how far a, 7, $18-20,29,169$

Court. (See also "JurisdicTION," “ PROCEDURE.")

justices, interested, 188

rules, construction of by, $67,83,89$

Craft Guilds, $1-3,15$

Criminal Procedure. (See "PROCEDURE, CRIMINAL.") 
Criminal Liability. (See also "PROCEDURE, CRIMINAL.")

annual statement, failure to send, 42

of association seeking new members, $10(b)$

for breach of contract, 67 , 68

of combinations, $6,8,9$ removed, 7, 9

copies of rules, distribution of false, 39

direct interference with others,

concerted, 74, 75, 79, 80

unconcerted, $59-68,79$, 80

documents, failure to send to registrar, 43

for embezzlement of trade union funds, 12

maintenance of members' action by trade union, 178

for misapplication of trade union property, $13,29,48$, $49(a)$

for molestation, see "Picke'ring"

for obstruction, see "PICKET. ING"

for restraint of trade, 8,83 , $84,88,126$

Damages,

claim for, 123

recovery of, when unenforceable against trade union, $123,126,128,135-137$, $140,145,148,150,154$

Decluaration. (See also "ProCEDURE," "ACTION," "INJUNCTION.")

claim for, 127, 128, 130, 15:3 enforcement of, $173(a)$

injunction, contrasted with, $127,128,134-136,139-$ $142,147,149,151-155$, $158,159,163-165$

for reinstatement, effect of, 161

of secession, 153
Declarator. (See "DeclaraTION.")

DEFINITION, 15-25, 91, 92

common law, 22

restrictive, $20,25-29$

statutory, $21-23,25-28$

Direct INTERFERENCE WITH The Disposal of Libour aND CAPITAL, 56-80

Dissolution of Trade Unions, App. II. and III.

how effected, 43,44

property, distribution of on, 160,161

registration of, 43

rules for, 38

\section{EMPLOYERs,}

agreements of, when in restraint of trade, 11

compulsion on, by picketing, 64, 6j

federation of, when a trade union, 21,23

Expulsion, 96, 108, 113, 116118,127

declaration arising from, $132,134-137,148,156-$ 161

injunction against,

when unenforceable, $128,13 \jmath-137,146$, 147

investigation of ground of, 166

Fine. (See also "Penalty.")

as trade union property, 132,160

unenforceable, $144(a)$

Frienduy Society

benefits, application of, actual and os tensible, distinguished, 101, 115

and trade benefits distin. guished, see "BENEFIT" registrar of, see also "RegistraR"

powers of under Friendly Societies Act, 18ฮ̄ 12 
Friendiy Society-continued. and trade union distinguished, 12, 13, 23, 24, $101,120-122$

and trade union purposes distinguished, 12,13 , $23,24,88-93,95-$ $101,103,105,108-$ $110,112,114,115$ separability of, 101,103,

Funds, 112,113

agreement as to, 140

when unenforceable, 124,145

amalgamation, effect on, 40,41

application of, administration contrasted with, $147,151,154,155,163$ injunction restraining, $128,133,134,139$, $140,144-150,153$, 155

audit of, $38,46,47$

benefits from, right to, 108, 158

forfeiture of, 167

income tax, exemption from, $\check{5} 1$, App. I.

investment of, 38

liability of for acts of agents, $72-74,175$

maintaining members' action with, 177,178

misapplication of, 11-13, $29,47,48$

participation in, 127,130 , $136,144-146,153,154$, 163, 164

rules for protecting, how far valid, 84,88

statement of, to registrar, 40,41

statement (annual) of, to inembers, 42

subscriptions and fines, 132, 160

GUILD. (See "CRAFT GuILD.")
IMmunities,

statutory, of trade unions, $6,7,9,11,15,57-62,68$, $69,72,75,80,81,123,124$

in trade disputes, 57-62, $63,69,72,75,79,80$

Incorporation. (See also "CoRPORATION," "ULTRA VIREs.")

effect of on trade union, 17$20,25-27,29,81,175$

INDICTMENTS. (See "Procedure, Criminal.")

INFANTS,

eligible as members of trade union, $33,52,53$

insurance of, restrictions on, $24,25,30,52,55$

nomination of, see "NoMINATION"

Injunction. (See also "Action," “Declaration," "Procedure.")

declaration, contrasted with, $127,128,134-136$, $139-142,147,149,151-$ $155,158,159,163-165$

expulsion from trade union, restraining by, 127,128

misapplication of funds, restraining, 157

parliamentary representation, restricting, App. VI. status quo, preservative of, $136,139,142,143,146,150$, $152,158,159,163,164$

INSURANCE,

company, trade union distinguished from, 24

of infants, restrictions on, $24,25,30,52--55$

National, and trade union, 29, App. V.

nomination, see "NomivaTION"

trade union powers as to, 24,25

Interdict. (See "InJunction.")

INTER-UNION ADMINISTRATION. (See also "AGREements," "JURISDICTION.")

jurisdiction with regard to, $152,154,170$ 
Intimidation. (See " PicketING.")

JURISDICTION OF Court. (See "ACTION," "CourT," "Procedure.") civil right, as basis of, $170-172$

contracts, validity and enforcement of, contrasted, 157, 159, 160

criminal, 180-189

indictment, description in, 189 trial by, $181(b)$ venue, 181

limitation of, as regards inter-union agreements, 14, 123-167 authorities on, 127-161 authorities reviewed, $161-167$

membership of union as basis of, 171

over voluntary associations, $132,170-174$

patrimonial right as basis of, $171-174$

proceedings against trade unions for acts of agents, when unenforceable, 73, 74

property as basis of, 154, 169-171, 176

summary, see also "JusTICES OF THE PEACE"

in England, 181-186

in Ireland, 181-186

in Scotland, 186-188

justices interested, 188

offence, description of, 188,189

penalties under, 63, 68, $68(a)$

Justices of the Peace. (See also "JURISDICTION, Summary.")

Combination Acts, powers under, 6,7

Conspiracy and Protection of Property Act, 1875 ,

powers under, $181-186$
Justices of the Peace-continued.

Friendly Societies Act, 1855, powers under, 11

Sheriff's Court (Scotland), jurisdiction of, 186-188

Statute of Apprentices, powers under, 5

wages, fixing of, 2, 4, 67

Trade Union Acts, powers under, 181-. 186

LABOUR,

combinations for bettering conditions of, $6,7,9,15$, 76

statutory regulation of, 35 LAND,

purchase and sale of, by trade union, 17, 29, 50

Larceny. (See also "CRIMINAL liability.")

of trade union funds, prosecution for, 13

Liability, Civil. (See "Civil LiabilitTy.")

Iitability, Criminal. (See "Criminal Liability.")

Limitation of Court's JuRisDICTION. (See “JuRISDICTION OF CourT.")

LOCAL AUTHORITY,

buildings of, use of, by trade unions, $50(a)$

representation on, see "Parliamentary REPRESENTATION"

Maintenance. (See "Action," " Criminal Liability," "Procedure.")

Malice. (See also "Liability, Crvil and CRIMinal.")

in breach of contract, 8 civil liability, $69(a)$, 72

criminal liability, $67-69$, 80

in conspiracy, 75 (1)

Masters. (See "EMPloyers.")

Molestation. (See "PicketING.") 
NAME,

change of,

effect of, 40,55

how effected, 40

of members, inspection of, 38

registered, 34,37

registered proceedings in, see "PROCEDURE"

registration of, 36,40 , App. II. and III.

right to, 17

Nomination. (See also “INFANT," “INSURANCE.") premium payable on, 52 requirements with regard to, $52,53(c)$

Objects. (See also "PURPOSES.")

purposes declared, how far real, 85, 88, 90, 92, 110,111, $113-11 \check{0}, 117,118,120,121$

statement of in rules, 17,36 , 37

Obstruction. (See "Picket-

OFFICE, ING.")

duties with regard to, 34 , 36,37

service at, 174, 175

Parliamentary and MuniCIPAL REPRESENTATION, injunctions restricting levies for, App. VI.

ultra vires, 27, 152

Penalty,

agreement as to unenforceable, 123, 124, $124(a)$, 132,133

for breach of rules, 130,135 , 136

description of, 188

in restraint of trade, 132, 133

interpretation of, 124 (a)

offence in action for reduction of, by Court, 63, 68, $68(a)$

rescission of, when unenforceable, 124, 128

summary jurisdiction with regard to, $63,68,68(a), 180$
Picketing. (See also "CRIMINAL LIABILITY," “IMMUNITY.")

compulsion by, 64,65

illegal, when, 62-65

information, communication of, 60,62

intimidation, 65

molestation, offence of, defined, 7, 9, 62 (a)

obstruction, 7

peaceful persuasion, $8,60(b)$ persistent following, 65, 67

seamen, liability of, 65

trespass, 61

watching and besetting, 61 , $63,64,67$

Powers. (See also "DefinITION," “ULTRA VIREs.")

benefit, provision of, ultra vires, 27,28

extent of, 26, 27

land, power to hold, 17, 29, 50

limited to statutory definition, 25, 26

medical society, contribution to, 51,52

municipal representation, 27

under National Insurance Act, 1911, 29, App. V.

newspapers, publication of, 27

of unregistered trade unions, 24, 28

parliamentary representation, 27

registration, acquisition by, 24,29

trade, conduct of, 27

Procedure, 168-189. (See

"Action," “JURISDICTION.")

civil, $169-180$

under s. 4, 1871 Act, 179,180

common interest, as right to sue, 178

costs, 178

criminal, 181-189

damages, see "DAMAGEs" 
Procedure-continued.

declaration, see "DEcLARATron"

injunction, see "INJUNCTION"

joinder of action, 175

maintenance of members' action by trade union, $177-179$

representative action, 176 , 177

in tort, 177

in contract, 177

under Trade Union Act, 1871 , s. 4, 126, 127, 179,180

trade union name, right to sue and be sued in, 19

Property - Trade Union, beneficial ownership of, 44 destruction of, 67,188

detention of, 47,48

dissolution, right to on, 160,161

fines or subscriptions as, 132 judgment against, enforcement of, 174

jurisdiction, based on, 154, $169-174,176$

of branch, 44

participation in, right to, $127,130,153$

as patrimonial right, 135 , $136,157,169-174-176$

as pecuniary right, 135,136 , $153,171-178$

recovery of, civil remedy for, $47-49$ criminal remedy for, 48,49

trade union, ownership by, 108,169

trustees, vesting of in, 44 vote, right to constitutes, $157,160,161$

Prosecution. (See "Criminal LIABILITY," “ JURISDICTION, Summary.")

Pubcic Policy, acts contrary to, 81,81 (b) restraint of trade, how far contrary to, $83,84,86,88$, $107-110,120-122$
Purposes,

benevolent, $14,15-19$

enforceable and unenforceable, 129, 130, 153

legality of, determination by Court, 83, 86, 88, 102, $103,121,122,153$

object, how far real, 85,88 , $90,92,110,111,113-115$, $117,118,120,121$

rules, statement of in, 37

trade, 4, 15-19, see also "Benefits"

Registered Trade Union. (See also "REgistrar," "REGISTRATION," “UNREGISTERED TRADE UNION.")

Assurance Companies Acts, exemption from, 24

contribution to medical societies by, 51,52

liability for acts of agents, 73,74

name of, see "NAME," "Procedure"

powers of, 17, 50

purchase of land by, 50

returns (annual) of, 17

rights and duties of, 46--55

rules of, 17, 34

trustees of, property vested in, 29

Registrar. (See also "Regis. TRATION," "REGISTERED T R A D E UNION," "Rules.")

amalgamation, powers as to, 41

annual statement of, 43

appointment of, 33

Assurance Companies Acts, exemption of unregistered trade union from, 29, 67

change of name, powers as to, 40

dissolution, powers as to, 43,44

name, registered, powers as to, 34,37

office, registered, powers as to, 34,37 
REgISTRAR-continued. penalties, recovery of by, 43 qualification of, English, 34 Irish, 34

Scottish, 34 qualification of assistant, 34 registration, powers as to, $30,32-34$

rules, alteration of, powers as to, 42

ministerial not judicial, 33

statement (annual), powers as to, 41,42

Registration.

(See also

" Registrar," " RegrsTERED Trade UNION.')

amalgamation, 41

change of name, 40

certificate of, see " CERTIFICATE"

domicile for, 36,37

effect of, 16, 17

on legality of trade union, 29, 100

how effected, $30-46$

of trade union as friendly

society void, 23,24

of trade union as limited

company void, 22,23

registrar's powers as to, 30 , $32-34$

regulations as to, $30-37$ of Secretary of State as to, $30-32$

Secretary of State, power to issue regulations, 30,31

void, 32

withdrawal of certificate of, 33,41

Representative Action. (See also "Action," "PROCEDURE.")

Court, power as to, 176 proceedings in absence of trustees, 176, 177

tort, in, as distinguished from contract, 176,177

Restraint of Trade. (See also "Agreement.")

agreement in, 10

combination in, $6-9,74$
Restraint of Trade-continued.

doctrine of, $81-122$

authorities on, 87-120 authorities reviewed, $120-122$

application of, to trade unions, 83, 84, 92, 94, 95, 103, 104, $109,110,111,112$, $116,117,119-122$, $129,132,133,160$

unlawful, 13, 14, 21 (a), $56,81-122$

Rules. (S'ee also "Registrar," "Registered Trade U N I O N," " REGISTRATION," " RESTRAINT OF TRade.")

accounts, audit of, in, 38

alteration of, $37,38,42$

amendment of, 37

benefits, provided for in, 131 books, inspection of, 38 construction of, $38,39,83$, 111

contents of, 37,38

copies of, 39,42

dissolution, provided for by, 43, 44, see also "REGISTERED Trade UNION."

enforceable and unenforceable, 81, 84, 86, 88, 91, $110,111,120-122$

errorsion, 37

illegal, effect on legality of trade union, 84, 86, 88-90

legal and illegal, separability of, 84 , $85,87-89,91$ $-94,109,110$, $120-122$

a question of fact, $94-100,107$, $112,113,116$

legality of, principles determining, 87-89, 102, $107-109$, 110, 115, 116, $118-122$

particulars in, $36-38$

name, 36

objects, 36

purposes of funds, 36 
RULES-continued.

registration of, 36,37

registrar's powers as to registration of, $36-38$ requisites in regard to, $39-44$

rescission of, 37

strike, how far illegal, 85$87,93,103-105,112$, $115,116,119-122$

subscription of by applicants to register, 29,30

validity of, investigation into, $38,39,166,167$

Secession,

declaration affirming, see "Declaration"

STRIKE. (See also "CombinaTION," “DIRECT INTERFERENCE," " "PICKETING.")

collective bargaining, $62(a)$, see also "COMBINATION

how far lawful, $76-78,86$, $87,95,101-105,115$, $116,119,120-122$

rules for providing payment during, 101, 102, 105, $111,112,119,128,144$

rules for sanctioning, 86, 101, 106, 118, 119

rules for supporting, 101, $105,110,112,115,116$

threatening, 8

Subscription. (See "ProPERTY.")

Summary JuRISDICTION. (See "Justices OF THE Peace," " Procedure.")

Summary Procedure (ScotLAND). (See “JustrCES OF THE PEACE.")

Threats. (See “Picketing.") Trade Dispute. (See also "STrike,". “ImmuNITIEs.")

acts in contemplation in furtherance of, $58,59,67,75$ combination in furtherance of, 10

definition of, $57-58$
Trade Union,

action of, see "Action"

agent, see "AGENT"

agreements, see "AGREEMENTs"

amalgamation, see "AMALGAMATION"

annual statement of, see

"Annual Statenent"

an association, see "AssoCIATION"

benefit, see "BENEFit"

branch, see " BRANCH"

combination, see "CoMBINATION"

corporation, see "CoRPORATION," “INCORPORATION"

civil liability of, see "IJIABILITY, Civin"

criminal liability of, see " Lifability, Criminal "

definition of, see "DEFINITION"

dissolution of, see "DissoLUTION"

expulsion from, see "ExPULSION "

friendly society distinguished from, 12, 13, $23,24,101,120-122$

separability of, 101, 103, 112,113

friendly society purposes distinguished, 12, 13, $23, \quad 24, \quad 88-93, \quad 95-$ $101,103,105,108-110$, $112,114,115$

funds-

history of, $1-20$

illegality of, at common law, 14

insurance by, see "INsurANCE

not an industrial and provident society, $23(a)$

internal agreements of, see " AGREEMENTS"

land, holding by, see "LaNd"

legality of, $82,83,86,87$, $89-92,102,111,112$, $119,120,121$ 
Trade Union-continued. membership of, right enforced by, see "JuRIsDICTION"

name, see "NAME"

name, right to sue and be sued in, see "ProcEDURE ",

objects of, see "OBJECTs" office, see "OFFICE" powers of, see "PowErs" property of, see "ProPERTY "

purposes, see "PuRPoses" registered, see "REGISTERED Trade Union"

registered and unregistered contrasted, 169

regulations of, 21,22

status of, $17,159,168$

unregistered, see "UNREGISTEREd Trade Union"

Trading Association,

a trade union, 22, 23, $23(a)$

Treasurer,

appointment of, 38

powers and duties of, 17, 29 rules as to, 38

Trustees. (See also "Action," " Procedure," " ProPERTY.”)

actions by and against, 17, $29,150,174$

age of, $44(a)$

branch, 179

injunction against misapplying funds, 133

power of branch to remove its trustees, 153
Trustees-continued.

funds, application of, by, $133,138,139$

land vested in, 50

liability of, $46,73,74$

non-members of union, 44

property vested in, 44, 45

removal of, 38,45

right to sue officers of trade union, 46, 47

rules as to, 38

Trusts. (See also "AGREEMENT," “Trustees.")

enforceable and unenforceable, 81, 82

misapplication of trust money, 134, 141, 142

trade union, nature of, 151

Ultra Vires, 20, 139, $144(a)$. (See also "Definition," "INCORPORATION.")

UnRegistered Trade UNION, Assurance Companies Acts, extent of exemption from, 24

incorporated, how far, 28, 29 legality of, 29, 100, 101

misapplication of funds of, 49,50

proceedings by and against, 176,177

registered trade union distinguished, 24, 28, 29

status of, 17

Watching AND Besetting. (See "Picketing.") 


\section{THEORIES OF PRODUCTION AND DISTRIBUTION.}

\section{A History of the Theories of Production and Distribution in English Political Economy from 1776-1848.}

By Edwin Cannan, M.A:, LL.D., Appointed Teacher of Economic Theory in the University of London. Demy 8vo. Cloth, $436 \mathrm{pp}$. $10 / 6$ net. (Inland Postage, $4 d$.)

Glasgow Herald. - "Ten years have elapsed since the first edition of this scholarly work came out. The new issue appears in a different dress, and at a reduced price. The alterations in the text are confined to minor verbal corrections. Two entirely new sections have been added to the last chapter. . . . Dr. Cannan's book is indispensable to all serious students of the development of economic theory. His method involves so close an adherence to the text of his authors that he cannot give us that oryanic review of the relation of the doctrines to the general life of the time which is the function of the great historian. This is not to disparage his minute and accurate researches. By his thorough-going exegesis he has considerably lightened the task of the coming economic historian in one important branch of inquiry."

\section{COMMUNAL CURRENCY.}

An Example of Communal Currency: The Facts about the Guernsey Market House. Compiled from original documents by J. THEODORE HARRIS, B.A. With a Preface by SidNeY Webs, LL.B. Crown 8vo. Cloth, $1 / 6$ net. Paper, 1/- net. (Inland Postage, 2d.)

Pall Mall Gazette.-." Most visitors to Guernsey have heard it said that the old Market House at St. Peter's Port was 'built' on 'paper,' but the explanation is a lengthy one and very rarely stated. Here Mr. Harris tells it with the aid of documents, and Mr. Sidney Webb in a preface admits it as a proof of the way in which, by the use of paper money and 'sense,' any community can equip itself with public buildings."

\section{THE PROVINCE OF THE STATE.}

By Sir Roland K. Wilson, Bart., author of "A Short History of Modern English Law," "An Annotated Edition of Sir G. C. Lewis's Use and Abuse of Political Terms," "An Introduction to the Study of AngloMuhammadan Law," "A Digest of Anglo-Muhammadan Law." Demy 8 vo. Cloth: $\mathbf{7 / 6}$ net. (Inland Postage, $\mathbf{4 d}$.)

Harold Cox in the Morning Post. - "At a time when political parties are engaged in advocating with almost frenzied zeal numberless schemes for enlarging the functions of the State, it is extremely useful to have published a book which examines with philosophic calm the whole question of State action."

\section{NEW ISSUES OF DEMOCRACY.}

By J. A. HoBson, author of "The Evolution of Modern Capitalism," "The Industrial System," \&c. Demy 8vo. Cloth, 6/- net. (Inland Postage, 4d.)

Westminster Gazette.- "None of our younger writers upon economics sees with clearer vision than Mr. Hobson. To the power of thinking great issues to their conclusion he adds that of lucid and even vivid expression. His later essays are admirable in their statement of the Liberal outlook upon the social questions of the day. His speculations are broad and courageous."

\section{THE NEW SOCIAL DEMOCRACY.}

A Study for the Times. By J. H. HARLEY, M.A., late Scholar of Mansfield College, Oxford, Vice-President of the National Union of Journalists. Demy 8vo. Cloth, 6/- net. (Inland Postage, 4d.)

Contents.-The Question Stated-Can Society be Transformed?-A Forecast in 1901-The Situation in 1910-Anatole France as a Socialist-Proudhon and the Labour Movement-The Collapse of Collectivism - The Rights of Reason - Review and Conclusion.

\section{P. S. KING \& SON, ORCHARD HOUSE,}




\section{PROBLEMS OF LOCAL GOVERNMENT.}

By G. Montagu Harris, M.A., Barrister-at-Law, Secretary to the County Councils' Association of England and Wales. Demy 8vo. Cloth, 10/6 net. (Inland Postage, 4d.)

Daily News. - "Mr. Harris has done an excellent piece of work in the production of this valuable and instructive volume."

\section{NATIONAL AND LOCAL FINANCE.}

A Review of the Relations between the Central and Local Authorities in England, France, Belgium, and Prussia during the Nineteenth Century.

By J. Watson Grice, B.Sc. (Econ.) Lond. With a Preface by Sidney WebB, LL.B. Demy 8vo. Cloth, 432 pages. $10 / 6$ net. (Inland Postage, 5d.)

Manchester Guardian.-_"The one thing certain is that, in the absence of careful studies such as that before us, we cannot hope to answer this question conclusively or solve quite satisfactorily any of the puzzles of local government or self-government."

\section{THE MUNICIPAL MANUAL.}

A Description of the Constitution and Functions of Urban Locil Authorities. By A. E. LAuder. Crown 8vo. Cloth, $3 / 6$ net. (Inland Postage, 3d.)

Contents.-Urban Local Governing Bodies-Constitution and General PowersPublic Health-Highways and Communication-Protective and Regulative PowersExtra Municipal Powers and Services-Financial-Education-Poor Law-AppendixIndex.

The Municipal Journal._" . . . exceedingly valuable book. . . . There is 'something more than a mere translation of legal expressions in the volume before us. There is a sympathetic approach to the problems of local government, and a knowledge of these matters that is not obtainable from mere Acts of Parliament and legal text books.

Mr. Lauder's method is a simple one, and from its simplicity proceeds its strength. He gives a preliminary sketch of the constitution of the authorities responsible for local government, and then classifies their duties in a few large groups, the Acts of Parliament under which their powers are conferred being indicated in the footnotes."

\section{URBAN DISTRICT COUNCILS:}

\section{How they Work and How to Work Them.}

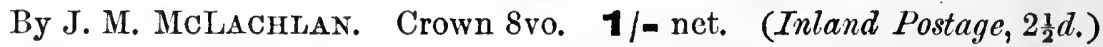

Municipal Journal. - "The essay is one that every clerk, accountant, surveyor, and medical officer of health to urban district councils would do well to acquire."

\section{COUNTY COUNCILS' ASSOCIATION'S PROPOSALS}

\section{FOR POOR LAW ADMINISTRATION}

\section{After Consideration of Majority and Minority Reports.}

Containing also views of Royal Commissioners on the Scheme. Demy 8vo. 1/- net. (Inland Postage, 2d.)

\section{P. S. KING \& SON, OPCHARD HOUSE:}


Edited by J. H. Whrtehouse, M.P. With an introduction by the Right Reverend John Percival, Bishop of Hereford. Demy 8vo. Cloth, 10/6 net. (Inland Postage, 4d.)

ConTEnTs.-Introduction, by the Bishop of Hereford-The Reform of Elementary Education, by J. H. Whitehouse, M.P.-The Economics of Boy Labour, by R. H. Tawney-Boy Labour : Some Studies in Detail, by Spencer J. Gibb-Boy Labour : Towards Reform, by Spencer J. Gibb and J. H. Whitehouse, M.P.-Boy Labour and the Factory System, by A. K. Clark Kennedy-The Boy Criminal, by J. M. Myers-The station Lounger : A Study, by Norman Chamberlain-Street Trading by Children, by J. H. Whilehouse, M.P.-The Supervision of Juvenile Employment, by J. H. Whitehouse, M.P.-Dr. Kerschensteiner's System of Education in Munich, by B. T, IC. Horsfall -The School as a Means of Social Betterment, by Marion Phillips, B.A., D.Sc., late Investigator to the Royal Commission on the Poor Laws-Children's Care Committees, by the Rev. W. H. H. Elliott, Head of Cambridge House-Homes for Working Boys, by the Rev. W. H. H. Elliott, Head of Cambridge House-Religious Influences and the Adolescent-Cross-fertilisation in Schools, by J. L. Paton, High Master, Manchester Grammar School-The Breaking Down of Caste, by Arthur H. Hope, Joint Editor " The Higher Education of Boys in England "-Recent Parliamentary and Other Inquiries Concerned with Problems of Boy Life, by Spencer J. Gibb-The Compulsory Age for School Attendance in Foreign Countries.

\section{JUVENILE LABOUR EXCHANGES}

\section{AND AFTER-CARE.}

By Arthur Greenwood, Head of the Economics Department, Huddersfield Technical College. With an Introduction by SIDNEY WEBB, LL.B. Demy 8vo. 1/- net. (Inland Postage, 2d.)

Times Literary Supplement. - "A close examination by a writer of much knowledge and experience of the problem of juvenile employment, with practical proposals of reform on the general principle of the need of co-ordination on a comprehensive scale of juvenile welfare organisations, whether State or voluntary."

\section{THE LABOUR EXCHANGE}

\section{In Relation to Boy and Girl Labour.}

By Frederick Keeling. Demy 8vo. 6/- net. (Inland Postage, $1 \frac{1}{2} d$.)

\section{INFANTILE MORTALITY AND INFANTS'}

\section{MILK DEPOTS.}

By G.F. M'Cleary, M.D., D.P.H., Medical Officer of Health, Hampstead ; late Medical Officer of Health, Battersea. Crown 8vo. 27 Plates. 6/- net. 10 copies, 50s. (Inland Postage, 3d.)

The writer discusses the varions causes of infantile mortality, and indicates the lines on which preventive action should move, and, in order to emphasise the importance of his subject, he devotes a chapter to the consideration of the decline of the birth-rate in this country and in the Colonies. The importance of improper feeding as a factor in infantile mortality is fully explained, and an account is given of the history and practical working of the infants' milk depôts in this country and in America, and of the similar institutions-the "Consultation de Nourrissons" and the "Goutte de Lait"-in France.

\section{P. S. KING \& SON, ORCHARD HOUSE,}




\section{BRITISH RURAL LIFE AND LABOUR.}

By Francis George Heath, author of "The English Peasantry," "The Romance of Peasant Life," \&c. Demy 8vo. Cloth, $10 / 6$ net. (Inland Postage, $4 d_{\text {. }}$ )

Devon and Exeter Gazette.-"We are in agreement with Mr. Heath . . . when he says the depopulation of the rural districts of the United Kingdom would be largely checked by the adoption of a system of freehold cottages and small holdings - . We are sure the conclusions at which he has arrived will be given very careful consideration . . The book is written in Mr. Heath's best style. He has gone deeply into his subject, and all who have sympathy with those who live in our rural districts, and with those who are closely associated with the soil, will derive a good deal of pleasure as well as information from a perusal of the volume."

Daily Telegraph._-"Has long made a special study of the subject with which he deals in this volume-a subject of almost incalculable importance to the country at large -. One solution . . Mr. Heath thinks is to be found in the increase of small freeholds, and he gives interesting particulars of his association with the late Lord Randolph Churchill in the attempt to formulate a scheme which should work to that end . . Interesting and suggestive, affording . . . a concise survey of the whole field."

\section{A HISTORY OF THE ENGLISH AGRICULTURAL}

\section{LABOURER.}

By Dr. W. Hasbach, Professor of Political Economy in the University of Kiel. With a Preface by SIDNer WeBB, LL.B. Demy 8vo. Cloth, $\mathbf{7} / 6$ net. (Inland Postage, $5 d$.)

Spectator.- "The thoroughness and the sincerity displayed in the author's investigation and writing are noteworthy. The London school of Economics and Political Science has done no greater service than in forwarding the publication of this trans. lation. . . . We hope that his book will be read by every country resident and every townsman who is desirous of obtaining a grip of some of the bottom facts of rural questions. With an acquaintance with these data, the idleness of much current talk about the problem of the countryside is patent."

\section{ENGLAND'S FOUNDATION.}

\section{AGRICULTURE AND THE STATE.}

By J. SAxon Milus, M.A. (Camb.), Barrister-at-Law at Inner Temple; author of "Landmarks of British Fiscal History"; with a Preface by the

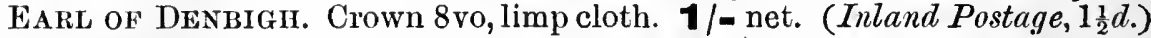

Daily Telegraph._- "No one can read an excellent little shilling volume prepared by Mr. J. Saxon Mills, under the title of 'England's Foundation,' without being impressed by the importance of its theme and the logic with which it is argued."

NATIONAL CONGRESS ON RURAL DEVELOPMENT AND SMALL HOLDINGS.

In connection with the Small Holdings and Country Life Section of the Festival of Empire, held at the Crystal Palace, 18th, 19th and 20th October, 1911. Official Report of the Proceedings. Crown 8vo. $\frac{1}{4}$ Cloth, 2/- net. (Inland Postage, 3d.)

Contents. - List of Persons and Associations attending or represented at the Congress-Address by the Right Hon. Earl Carrington, K.G. (late President Board of Agriculture)-Co-operative Credit as an aid to Rural Development, by H. W. WolffAgricultural Co-operation, by Clement Smith-Co-operation, by J. T. CorbettProduction, by $\mathbf{H}$. Vincent (Lecturer Vincent College)-Marketing of British Eggs and Poultry, by Verney Carter (National Poultry Organization Society)-Pigs and Small Holdings, by Sanders Spencer-Marketing of Fruit and Vegetables produced on Small Holdings, by Geoffrey Hooper-Equipment of Small Holdings, by Henry T. Tate - Rural Education, by Christopher Turnor, author of "Land Problems and National Welfare"-Rural Education, by Evan R. Davies: Director of Education, Carnarvonshire-Discussions.

\section{P. S, KING \& SON, ORGHARD HOUSE,




$$
\checkmark
$$

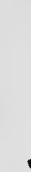

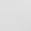





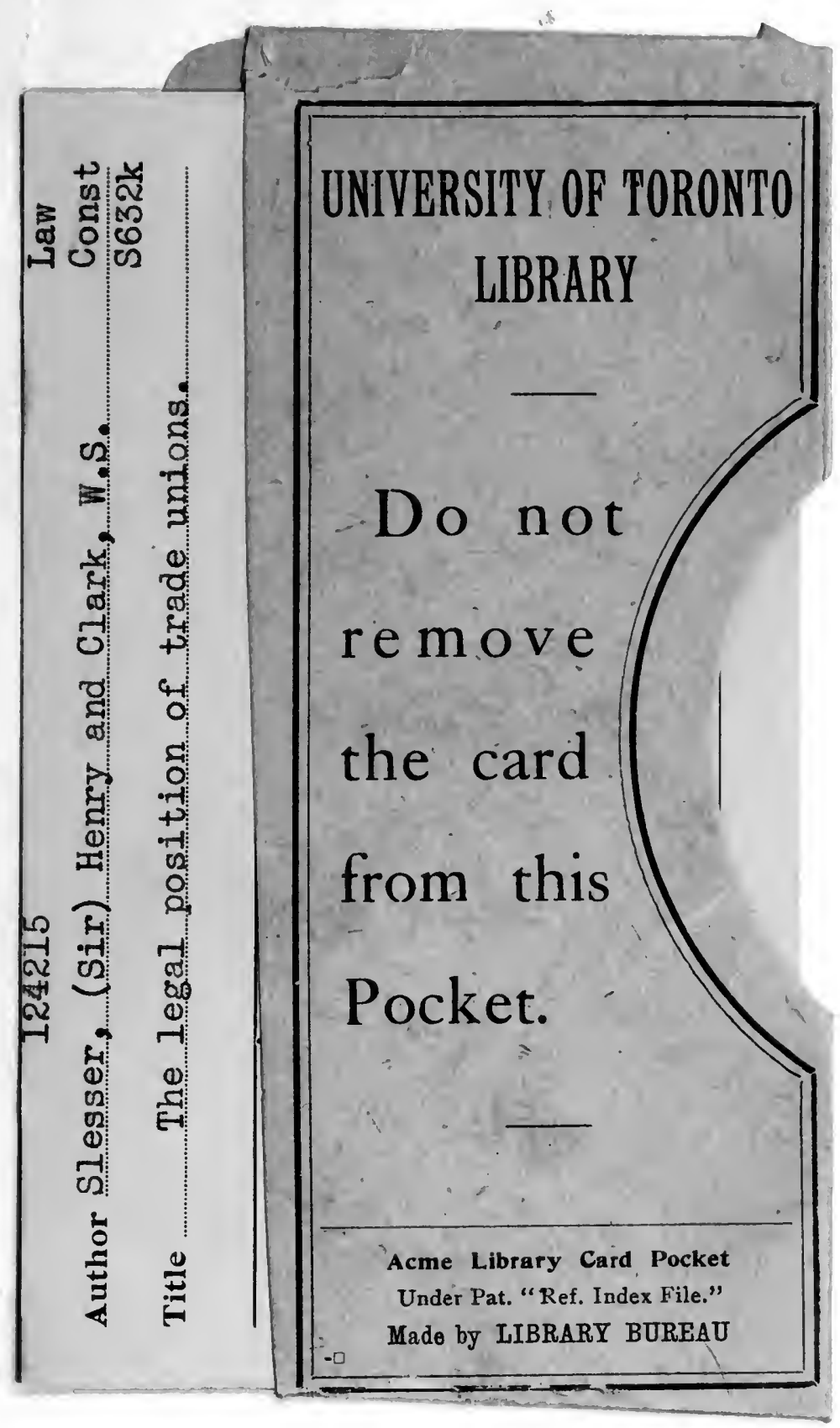


